



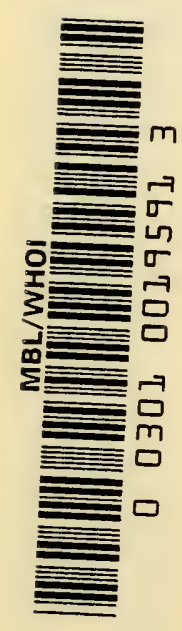




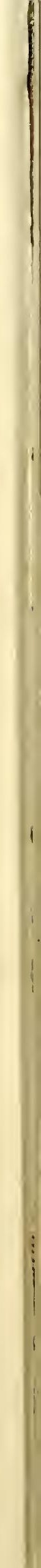


THE MAST CELLS 
This book is protected under the Berne Convention. It may not be reproduced by any means in whole or in part without permission. Application with regard to reproduction should be addressed to the Publishers.

(C)

E. \& S. Livingstone Ltd., 1959 


\title{
THE MAST CELLS
}

BY

\author{
JAMES F. RILEY \\ M.B., Ch.B.(Hons.), M.D., Ph.D., D.M.R.T., F.R.C.S.E. \\ Consultant Radiotherapist, Royal Infirmary, Dundee. Lecturer in Radiotherapy, \\ University of St. Andrews
}

FOREWORD BY

SIR HENRY DALE

O.M., G.B.E., F.R.C.P., F.R.S.
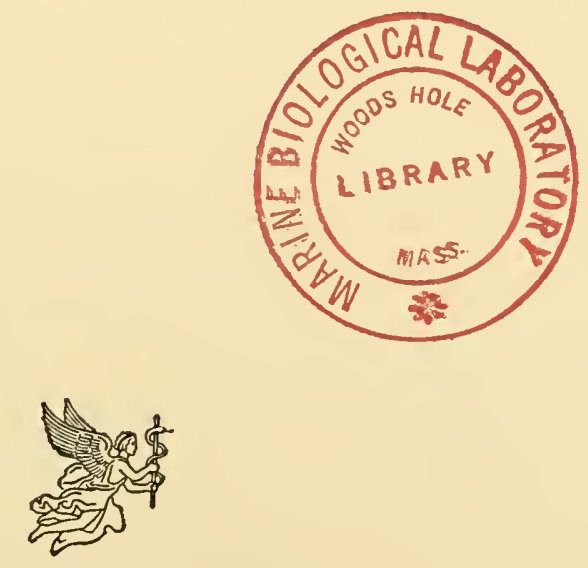

E. \& S. LIVINGSTONE LTD. EDINBURGH AND LONDON 


\section{F O R}

J. M. D. AND G.B.W. 


\section{FOREWORD}

$\mathrm{D}$

URING the past few years the so-called 'mast cells' have very rapidly acquired a new interest for the interpretation of phenomena and the solution of problems which have been much longer familiar to students of physiology and pathology. The initiative and the effective stimulus to the studies from which this new interest has arisen can be attributed to the original work carried out and published in a succession of papers by Dr. Riley, with Dr. G. B. West and his other colleagues. The publication of this Monograph by Dr. Riley, assembling and presenting for discussion all this new and highly suggestive evidence, will certainly be widely welcomed, not only by those who are themselves active in related fields of research, but also by the many others who may well have found it difficult to follow the rapid unfolding of knowledge about these cells, and especially its recent and rapid development.

As Dr. Riley duly records, we owe the first differential recognition of the mast cells to the late Paul Ehrlich, whose pioneer publication on the subject gave evidence, indeed, of the early ripening of his remarkable genius; for the paper which first described and named these cells, characterized by the packing of their cytoplasm with large, basophile granules, had been Ehrlich's graduation Thesis. I find myself less clearly convinced than Dr. Riley seems to be, with regard to the appropriateness of the name, 'Mastzellen' (= fodder cells, or cells concerned with fattening, or nutrition), as proposed by the young Ehrlich to indicate the function which he attributed to these cells, but for which, in fact, he had no evidence but their histological appearance, including the basophile staining of their granules by which he recognized them. A short name, however, is obviously needed for convenient reference. In its English translation, 'mast cells' has practically no such functional implication as the original German form had; and, in any case, a proper respect for priority and for Ehrlich's memory would make us retain the name which he proposed, and which has passed into such general use.

Dr. Riley's attention appears to have been first drawn to the functional possibilities of the mast cells, by the observation of their unusual abundance in the tissues adjacent to experimentally induced cancers of the skin in mice. Later he became acquainted with the results obtained by Jorpes and other Scandinavian workers, who had observed a significant correspondence between a special abundance of these cells in different tissues and the respective yields obtainable from them of the anticoagulant principle known as 'heparin'. This had been so named by its discoverer, W. H. Howell, on account of his original finding of it in extracts from the liver of the dog-an organ in which the mast 
cells were later found to be conspicuously abundant. It was apparently this association of the dog's liver with the production of heparin, which first led Dr. Riley, and those who became associated with him, to consider the possibility that the mast cells might also be the source of the histamine; since the anaphylactic shock and analogous reactions, in the form characteristic of the dog, were known already to be due, essentially, to the effects of histamine and heparin poured into the general circulation, as the result of a primary reaction in the liver. Dr. Riley and his co-workers were thus led to make a more general survey of the relation between the abundance, on the one hand, of mast cells in different organs and tissues of a number of species, including examples of mast-cell tumours, and the yields, on the other hand, of histamine obtainable by extraction from the same normal and pathological sources. I do not doubt that any careful student of their results will find that the evidence here presented shows a highly significant correlation between the mast-cell content of solid organs and their yield of histamine to artificial extraction; and such a student will surely be impressed, as I am, with the reasonableness of the deduction that the mast cells in such tissues, and, indeed, the characteristic, basophile, metachromatically staining granules which occupy so much of the cytoplasm of those cells, are by far the most probable source of that histamine.

It must be borne in mind, on the other hand, that this staining of the mast-cell granules does not, in itself, provide evidence for the presence in them of histamine. Histamine, on the contrary, being itself a base, has a special affinity for the acidic dyes, such as eosin and phloxin, with which it combines in vitro to form precipitates. Before the demonstration by Dr. Riley and his colleagues of the connexion between mast cells in a tissue and its yield of histamine, there had been highly suggestive evidence of a similar association between the yield of histamine from the blood of different animal species, including that of man, and its richness in white cells with an eosinophile granulation. In those of us who were familiar with these earlier observations, the news of the discovery that, in the tissues, the occurrence of histamine was associated with that of the hasophile mast cells, produced, at first glance, a sense of paradox, or conflict of evidence. And it seems to me that we have the more reason for gratitude to Dr. Riley and his co-workers for having gone steadily forward, undeterred by any such prejudice, to collect and assemble the data, which have now so abundantly confirmed their first observations. For my own part, I am expecting that the new association which they have so convincingly established, between histamine and the heparin-containing mastcells of the tissues, will be found to have an increasing importance, for the assignment to histamine, and to the other amines, such as serotonin, now coming into view as mast-cell constituents, of their various functional roles in a range of physiological and pathological reactions.

H. H. DALE. 


\section{PREFACE}

T

HIS booklet on the mast cells is in two parts. The first is a review of the literature, mainly up to 1950 when the work described in the second part began. The second part is essentially the thesis, "Functions of the Tissue Mast Cells', which was accepted in 1958 by the University of St. Andrews for the degree of Doctor of Philosophy.

In preparing the manuscript for publication I have been reminded of the very great help which I have received from other workers at various stages, and which I wish freely to acknowledge.

Some of the early experiments on the histology and histochemistry of mast cells were carried out in Edinburgh in collaboration with Dr. J. M. Drennan of the Department of Pathology. Mr. (now Professor) D. M. Douglas and Dr. J. P. Graham of the Wilkie Research Department, Edinburgh, helped me in experiments on peptone shock in dogs. Later, in Dundee, when a pharmacological approach was required, Professor R. B. Hunter not only offered me the very considerable facilities of his department, but also introduced me to Dr. G. B. West, without whose cheerful enthusiasm and unlimited patience further progress would have been slow indeed. Much of the present work on histamine in mast cells has already been published in collaboration with Dr. West, and this forms the main body of the second part of the book: where it is appropriate, a reference to the original paper is given under the chapter heading. On the departure of Dr. West for London, the pharmacological investigations were continued by his successor, Dr. P. B. Marshall, and by Miss Rosemary Cass. Dr. West and I have acknowledged elsewhere the valuable contributions of Mr. K. W. Head of the Royal (Dick) School of Veterinary Studies, Edinburgh, who supplied us with much unusual veterinary material, and of Mr. S. W. Stroud of the Research Division, Boots Pure Drug Co. Ltd., Nottingham, for his assistance with the heparin assays. In some experiments the initial extraction of the heparin was carried out by Dr. D. M. Shepherd of the Department of Pharmacology, Queen's College, Dundee, to whom we also owe our thanks for his advice on problems connected with the chromatography of tissue extracts. An interesting off-shoot of the present study has been the work of Dr. J. D. B. MacDougall of the Department of Anatomy, who has succeeded in growing various types of mast cell in tissue culture and has himself published several papers on the subject. I record with special gratitude the constant flow of encouragement and advice of Professor A. C. Lendrum of the Department of Pathology: many of the paraffin sections were cut and stained by Mr. W. Slidders in Professor 
Lendrum's department, and all the photomicrographs were taken there with the aid of his technician, Mr. J. W. Corkhill.

Finally, I wish to place on record the debt of gratitude which Dr. West and I owe to the constructive criticism and generous advice of Sir Henry Dale throughout the whole of this work. Sir Henry, himself a pupil of Ehrlich, was among the first to accept our evidence on the cytological location of histamine in mast cells and to suggest fruitful means for obtaining further information. For our part we were honoured in being invited in April 1955 to take part in the Symposium on Histamine organized by the Ciba Foundation to celebrate Sir Henry's eightieth birthday. Sir Henry now does me the even greater honour of writing a foreword to this account of a problem on which he himself has contributed so much.

Dundee, 1959.

JAMES F. RILEY. 


\section{CONTENTS}

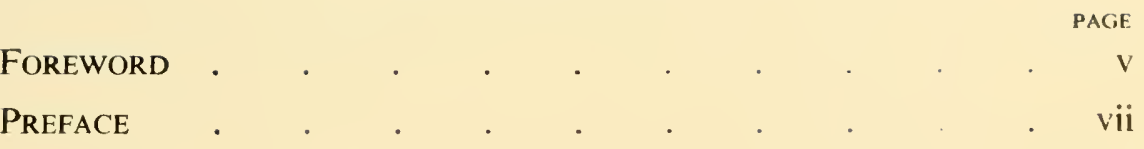

CHAPTER

\section{PART I \\ REVIEW OF THE LITERATURE}

I. The Discovery of the Mast Cells . . . . . . 3

II. The Mast Cell in Evolution . . . . . . . 5

Invertebrates; Vertebrates, including Man.

III. The Blood Mast Cell, Basophil or Mast leucocyte - 17 Tissue Mast Cells in Bone Marrow.

IV. Mast Cells in Pathological Conditions . $\quad . \quad$. $\quad 21$ Chronic Inflammation and Tumours.

V. The Mast Cell and Heparin . . . . . . . . 28

\section{PART II \\ EXPERIMENTAL}

VI. INTRODUCTION

The Mast Cell and Carcinogenesis; The Problem of the Shocked Dog.

VII. Detailed distribution of Mast Cells in Cattle and in the Rat 39 Relationship of Mast Cells to Serous Membranes and Blood Vessels.

VIII. The Effects of Histamine-Liberators on the Mast Cells of THE RAT . . . . . . . . . . . 59

IX. Histamine in Tissue Mast Cells: Normal Tissues • • 71

X. Histamine and Heparin in Tissue Mast Cells: Pathological CONDITIONS . . . . . . . . . . . 77

XI. The Effects of a Specific Histamine-Liberator, Compound

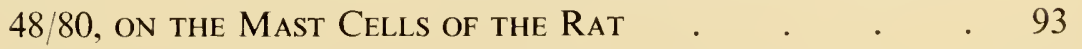

XII. The Effects of the Same Histamine-Liberator ON TWO difFERENT SPECIES, MOlSE AND RAT . . . . . 109 
Xili. Binding of Histamine in the Mast Cell: the Nature of the

Mast-Cell Granule . . . . . . . 116

XiV. Non-Mast Cell Histamine: the High Histamine Content of

THE Pyloric Mucosa . . . . . . . 132

XV. The Function of Heparin . . . . . . . . 137

Peptone Shock in the Dog; Fate of Heparin in the Rat treated with a HistamineLiberator; Mast Cells and the Connective Tissues.

XVI. Mast Cells and Histamine in the Skin . . . . 144 Normal Skin of various Species; Precancerous Skin of Mice.

XVII. General Discussion: Functions of the Tissue Mast Cells . 160 BIBLIOGRAPHY . . . . . . . . . . 165 INDEX $\quad . \quad$. . . . . . . . . 179 
PART I

REVIEW OF THE LITERATURE 



\section{CHAPTER I}

\section{THE DISCOVERY OF THE MAST CELLS}

$\mathrm{O}$ $\mathrm{N}$ the 17th January 1879 the Physiological Society of Berlin heard a remarkable paper by a remarkable young man. The speaker was Paul Ehrlich; his subject a granular cell of the loose connective tissues which he had discovered as a medical student some two years previously (Ehrlich, 1877) and for which he had proposed the name 'Mastzellen' (well-fed cells) since the cells are more numerous in connective tissue whose nutrition is enhanced (Ehrlich, 1878). Ehrlich pointed out that not only do the granules of mammalian mast cells display great avidity for basic dyes, but that they also tend to alter the shade of the dye ("metachromasia'). Later, with his own pupil, Westphal (1891), he stressed a second characteristic feature of the mastcell granules in many species, their solubility in water. As Michels $(1938$, p. 262) remarks, 'Uncounted pages of useless and misleading research have been the result of the failure on the part of many investigators to heed the admonition originally given by Ehrlich and Westphal, that the mast granules are soluble in water and that to preserve them tissues must be fixed in 50 per cent alcohol and stained in alcoholic thionine'.

From what we know of Ehrlich's enthusiastic temperament (Marquardt, 1949) it is not difficult to picture him giving this, his first public dissertation. But the occasion was more than that. In discovering the mast cells Ehrlich had discovered a principle which was to guide him through his working life and inspire his later studies in chemotherapy. That the biological action of a drug is a direct consequence of its molecular architecture is now a pharmacological axiom so firmly established as to pass without comment: in Ehrlich's day when medical treatment was still empirical and symptomatic, the idea of 'specific affinity' between drug and protoplasm was a novel conception. It is said (Plesch, 1947) that the idea of specific affinities first germinated in Ehrlich's mind when he was working in the laboratory of his cousin, Karl Weigert, who had begun to use the new technique of staining histological sections. While examining one of Weigert's slides under the microscope Ehrlich began to speculate why one part of the cell should stain selectively with a particular dye leaving the rest of the cell unstained. It was not long before he was seeking the answer.

Success came early. Ehrlich obtained samples of the latest commercial dyes from German manufacturers who were then turning to such profitable account Perkin's original discovery in Manchester of the first synthetic aniline dye, mauve. On applying some of the new dyes to connective tissue Ehrlich 
discovered the mast cells. The strong affinity of the granules for basic dyes and the metachromatic staining reaction enabled Ehrlich to differentiate his Mastzellen from the heterogeneous collection of 'embryonal' or 'plasma' cells described by his teacher, Waldeyer (1875). Granular cells were first seen in the peritoneum of frogs by Von Recklinghausen (1863). Waldeyer, who described and depicted similar cells with refractile granules around small blood vessels, believed them to be precursors of the fat cells which form the outer layer of the perivascular sheath. Ehrlich showed that Waldeyer's granular cells do not contain fat by pretreating the tissues with fat solvents, and that dyes which stain fat leave the granules of mast cells unstained. According to Ehrlich the mast granules represent an albuminous reserve substance for the connective tissues and are the products of differentiation in healthy cells of the fixed mesenchyme.

Ehrlich then went on to study the staining reactions of the blood cells, laying the foundations of modern haematology on the basis of the specific affinities of the leucocytes for various dyes (Ehrlich, 1891; Ehrlich and Lazarus, 1898). Here again he encountered cells with basophilic, metachromatic granules, and thus came to recognize two types of mast cell; the first, derived from, and living in the connective tissues (tissue mast cell), the second-the counterpart of the neutrophil polymorph and eosinophil leucocyte-whose origin is in the bone marrow and whose habitat is the peripheral blood (blood mast cell, basophil or mast leucocyte). Not the least of Ehrlich's genius was his intuitive appraisal of the limitations of the experimental methods of his day. His later work on cancer is typical of this. So it was with the mast cells. He made no attempt to apply experimental methods to the problem of their function or to characterize chemically the granule substance. Having described the morphological features of blood and tissue mast cells, he left it to others to elucidate the role of these cells in the organism, concluding his brief introduction (Ehrlich, 1879) with the hope that one day the mast cells would be found to have an interesting function. It is the purpose of this monograph to trace the subsequent story and see to what extent Ehrlich's hopes have been fulfilled. It is an interesting story, and no less interesting in the certainty that the full account has yet to be written. Even now we are in the midst of one of the periodic waves of enthusiasm for the mast cells, and there may thus be workers in many fields to whom an interim account will be acceptable. This is built around the researches of my colleagues and myself in Scotland who have investigated the relationship of the mast cells to tissue histamine. At the same time we have endeavoured to retain something of the wider perspective which appealed so strongly to Ehrlich: that is perhaps the outstanding feature of his undergraduate Thesis which has only recently become available for study (Ehrlich, 1878). 


\section{CHAPTER II}

\section{THE MAST CELL IN EVOLUTION}

$\mathrm{D}$

URING the sixty years which followed Ehrlich's discovery, research on the mast cell was almost entirely histological. Controversies arose but their resolution for the most part merely emphasized the soundness of Ehrlich's original work.

Thus Ranvier (1890) described his 'clasmatocytes'- cells which cast off ('clasmatose') fragments of protoplasm; but it is clear from Ranvier's own descriptions that many of the cells which he originally recognized as clasmatocytes are tissue mast cells. In the newt and salamander especially the mast cells are exceptionally large and irregular in shape and are easily damaged during preparation of the tissues. Moreover, Ranvier used a watery fixative ( 1 per cent osmic acid), a watery stain (violet 5B) and a watery mountant (glycerine) whereby the granule substance rapidly diffuses from the cytoplasm. Using the same stain and a more adequate fixative, Raudnitz (1883) had already successfully demonstrated mast cells in man. The situation was finally clarified by Jolly (1900) who clearly distinguished mast cells from clasmatocytes in mammals and showed that the huge arborizing cells in amphibia are the tissue mast cells of these species.

The use of a watery technique likewise led Pappenheim and his school to assert that mast myelocytes are lacking in the bone marrow of the rabbit and in the marrow of patients with myeloid leukaemia, thereby implying that the numerous blood mast cells in both are derived from precursors in the tissues. This misconception persisted until Maximow (1913) and Ringoen (1919) conclusively re-established Ehrlich's views and again stressed the extreme water-solubility of the mast granules in certain species (Kanthack and Hardy, 1894). Not all mast granules are so readily soluble; the mast granules of the rat are surprisingly resistant to water (Paff and Mergenthaler, 1955). It will be shown later that once the limitations of a watery technique for mast cells are appreciated the method can be used to yield information concerning the physiological function of the cells.

In only one respect did Ehrlich's early work fail to find complete acceptance later. It will be recalled that Ehrlich's classification and nomenclature of the granular leucocytes rested on the 'specific affinities' of the granules for various dyes. As the scope of the search for mast cells widened, it became increasingly apparent that in many lower organisms not only are the mast granules frequently non-metachromatic, but that, at least during certain phases of their life history, they may even be acidophilic. The significant homology for the mast cell is 
rather the connective tissue habitat of the cell and the size and number of its granules than the immediate staining qualities of the granules themselves: 'coarse granulocyte' is perhaps the more appropriate term for such cells. With these considerations in mind we may first review in general terms the evolutionary development of the mast cell in a series of organisms of increasing complexity, and later examine in somewhat greater detail the distribution of tissue mast cells in vertebrates.

\section{INVERTEBRATES}

It has been suggested that the metachromatic bodies in certain bacteria and the volutin granules in yeasts (Guilliermond and Marvas, 1908; Wermel and Sassuchin, 1927) correspond to mast cells in higher organisms; but in view of the doubtful histo-chemical significance of metachromasia no great importance can be attached to these claims (Tulasne and Vendrely, 1947; Duguid et al, 1954). Nevertheless, in such lowly multicellular organisms as sponges (Cotte, 1904) and simple coelenterates (Kollmann, 1908) well-defined basophilic granular cells are already present in the connective tissues from which, in some species, they escape as free cells into the primitive body cavity. Both Cotte (p. 547) and Kollmann (p. 213) are of the opinion that these cells correspond to the mast cells in higher forms. Such 'amoebocytes with spherules' are common in echinoderms, especially in the walls of the ambulacratory pockets of the star fish and sea urchin (Kollmann, 1908; Kindred, 1926) from which a yellowish substance can be extracted from the granules by transferring the organisms to tap water (Pequegnat, 1948). According to Kindred (1926) the 'coarse granulocyte' in echinoderms is first recognizable as a connective tissue cell with clear cytoplasm, and thus corresponds to the 'hyaline cell' of Kollmann (1908). Under conditions of good feeding the cell develops bulky refractile spherules which stain with basic dyes. The spherules then progressively become yellow and shrunken; finally often red and acidophilic. Thus the intermediate coarse granulocyte in invertebrates, the cell with colourless, basophilic spherules, bears the most obvious resemblance to the mast cell of higher animals. Kollmann found these cells in the connective tissues of various invertebrate forms which he examined. 'Les cellules spheruleuses ... restent habituellement cantonnées dans le tissu conjonctif. On peut vraisemblement les comparer aux Mastzellen des Vertébrés' (Kollmann, p. 200). Thus it will be observed from the standpoint of comparative morphology that mast cells are regularly demonstrable before the demand for oxygen and nutriment has led to the evolution of a definitive blood-vascular system. Whatever may be the function of the mast cells in these simple organisms it can hardly be concerned with the blood.

The common blood cell of many insects appears to be concerned function- 
ally with the connective tissues (Lazarenko, 1925). In certain species the basophilic cytoplasmic bodies stain strongly with the periodic acid-Schiff method for a neutral mucopolysaccharide (Ohuye, 1952; Ohuye and Horikawa, 1956) 'which forms or contributes to the connective tissues and basement membranes' (Wigglesworth, 1956).

With the evolution of an 'open' type of circulation, as in arthropods, more typical mast cells become demonstrable around the walls of the smaller arteries whose contents empty direct into the tissue spaces. Over a century ago Häckel (1857) described an adventitial cuff, a 'Zellgewebe', surrounding the smaller blood vessels of the crayfish. By injecting a suitable vital stain into the pericardial sac or primitive heart of the crayfish, myriads of cells filled with metachromatic granules can be demonstrated in Häckel's perivascular sheath. Only rarely does such a tissue basophil escape into the circulation (Hardy, 1892).

\section{VERTEBRATES}

However, it is at the next evolutionary level that tissue mast cells appear in an abundance which makes it difficult to escape the conclusion that their number and situation foreshadow something of their function in higher organisms. The tissues of many Ichthyopsida (fishes and amphibians) are teeming with mast cells in contrast to the virtual absence of mast cells in the blood. So intimately is the distribution of the mast cells bound up with the evolution of the blood vascular system that it is worth while pausing for a moment to review briefly the development of the blood-forming tissue itself and the progressive specialization of its component parts (Jordan, 1926; Jordan and Speidel, 1930).

\section{Evolution of the blood-vascular system}

In the lancelet amphioxus (branchiostoma) the few free mesenchymal cells in the blood are derived from undifferentiated precursors scattered throughout the body. With the advent of the primitive craniate fishes, the jaw-less cyclostomes, there begins a process of segregation and specialization of bloodforming tissue which may be traced progressively forwards to the mammals. From being distributed diffusely throughout the wall of the intestine, as in the hagfish, the haemopoietic tissue becomes aggregated in the so-called spiral valve of the larval lamprey and forms a compact nodule in the wall of the stomach of the African lung fish. In the cartilaginous fishes the active tissue is now attached to the stomach by a mesentery and may thus more properly be termed a spleen. At the amphibian level, especially in the tailless anurans, the spleen is concerned almost exclusively with the production of erythrocytes and thrombocytes, granulopoiesis still being carried on at former sites of blood 
formation throughout the body. With the evolution of the bony fishes the marrow begins to usurp some of the functions of the spleen and becomes the predominant tissue for haemopoiesis. According to Jordan and Speidel (1930, p. 375) the mechanical advantage conferred on the organism by the development of tubular bones also led indirectly to ideal conditions for blood formation. - The diaphyseal content of hollow bones is fundamentally related to the nutritive requirements of the bones. Thus, in a sense, the practical postnatal restriction of hemocytopoiesis to bone marrow in higher forms, especially mammals, was accidental. Arising apparently as an incidental aspect of the mechanism providing for the most favourable nutritive conditions for hollow bones, it becomes appropriated as offering more favourable conditions for blood formation. The spleen, accordingly, becomes of less importance at the higher evolutionary levels after the appearance of long bones. Its original multiple function becomes apportioned among lymph nodes, perhaps thymus, and bone marrow.' It is, of course, well known that extensive destruction of red bone marrow even in mammals can be followed by the resumption of extramedullary blood formation in the original haemopoietic centres of the body, and that after splenectomy the marrow may perform the reciprocal function of producing lymphocytes and monocytes. In view of the multipotent capacity of the marrow for blood formation, it is not surprising that along with the neutrophil and eosinophil leucocytes the marrow also produces variable numbers of blood mast cells. In general there is an inverse numerical relationship between the numbers of blood and tissue mast cells in a particular species (Maximow, 1910): however, with few exceptions the number of blood mast cells is small compared with the number of tissue mast cells which continue to be produced at sites of former haemopoietic activity.

Meanwhile, in course of evolution, another specialized type of tissue has come into being. This is the lymphatic system whose origins can also be traced to the widespread primitive haemopoietic tissue of lower animals. Portions of the multipotent mesenchyme become aggregated into foci specializing in the production of lymphocytes; capsulated lymph nodes make their first appearance in water birds (Further, 1913). Even so, the spleen in birds continues to play a significant role in haemopoiesis, its removal being followed by increased haemopoietic activity elsewhere, as in cold-blooded animals: 'A striking example is presented by the differentiation of the mast cells along the vessels of the omentum. ... An analogous development of mast cells is seen under the epithelium of the intestine' (Dantschakoff, 1916, p. 485). As the importance of the marrow for haemopoiesis increases still further, the spleen eventually produces little else but lymphocytes and monocytes. Yet there remain, even in the mammals, scattered traces of the original blood-forming tissue which continues to produce the granular cells of the connective tissues. These are 
the tissue mast cells. It will be helpful to keep this genealogical background in mind when the apparently capricious distribution of mast cells in higher ol ganisms is under consideration.

\section{Detailed distribution of mast cells in vertebrates}

LOWER VERTEBRATES. In lower vertebrates, production of coarse granulocytes is for the most part restricted to certain well-defined sites, notably gut, mesentery, subcutaneous and intermuscular tissue, liver, spleen, kidney, gonads, perivascular tissues generally, lungs (when present) and to a lesser extent pancreas and even skull (Drzewina, 1905; Michels, 1923).

Alimentary tract. In the alimentary tract of Ichthyopsida (fishes and reptiles) the 'lymphoid tissue' (Drzewina, 1905) forms an almost continuous sheath between mucous membranc and muscle, a region which corresponds to the location of the Peyr's patches and isolated lymphoid nodules in man. Drzewina failed to find granulocytes in the alimentary lymphatic tissue of carp though they have been described there by Al-Hussaini (1948). In the carp coarse granulocytes are particularly abundant in the perivascular tissues and serous membranes, especially mesentery (Michels, 1938). Greene (1912) found in the gut of the King salmon a layer of coarse granular cells so dense that he refers to it as the 'stratum granulosum'. However, Arvy (1955a) points out that apparently similar cells in the trout more closely resemble the granular cells of the exocrine pancreas; they are decidcdly more acidophilic than basophilic in their staining properties. Numerous coarse granulocytes were seen in the gut of other salmonoids by Bolton (1933) who has no hesitation in calling them 'mast cells'. Migratory activity and concomitant change in staining properties of the coarse granulocytes in teleosts were clearly recognized by Al-Hussaini (1949). Duthie (1939) shows coarsely granular basophils migrating towards mucosal and serous surfaces: as the surface is reached the now acidophilic granules become orientated in a manner which suggests (p. 40) 'a discharge of the granules on to the surface of the epithelium'. It will be seen later that there is evidence for limited migratory activity of perivascular mast cells tcwards mucosal and epithelial surfaces in higher vertebrates (Riley, 1953a; Arvy, 1956a; McGovern, 1956). Typical mast cells have been described in the gut of various Batrachians (anurans and urodeles) by Arvy (1955b).

Heart and blood vessels. As long ago as 1857 Leydig described a richly cellular sheath surrounding the mesenteric vessels in several teleostean (bony) fishes. The regular occurrence of haemopoietic tissue in this situation is well seen in certain 'ganoids' (e.g. sturgeon). Drzewina (1905) describes such a tissue clothing the heart of the sturgeon and extending along its blood vessels; Ohuye and Ochi (1954) observed a similar genesis of basophilic granulocytes in a urodele, the Japanese newt. According to Drzewina the formative tissue 
bears a striking resemblance to the mammalian lymph node: however, it also gives rise to coarse granulocytes, and these, in the sturgeon, may contain both basophilic and acidophilic granules within the cytoplasm of the same cell. This is a disturbing state of affairs to one brought up strictly in the Ehrlich tradition of a cytological nomenclature based on specific affinities. Drury (1914) observed typical eosinophils free in the peritoneal fluid of bony fishes but no basophils, since "they do not migrate from their normal place of occurrence, around the blood vessels, amongst the teleostean fishes'. It will be emphasized later that perivascular tissues are outstanding sites for the formation of mast cells in mammals.

Kidney and gonads. In Ichthyopsida the kidney tubules are embedded in a mass of reticular lymphoid tissue from which develop cells with amphophil, basophil and acidophil granules, the granules of basophils usually being coarser than the rest (Drzewina). This tissue in a ganoid, Polyodon spathula, was extensively studied by Downey (1909) who discusses the evidence for secretion by the granular cells. Of the three main types recognized by Downey, the cells with basophilic granules eventually become metachromatic and finally disintegrate through the diffusion of the metachromatic material into the cytoplasm and the formation of multiple vacuoles. Blood formation is also active, in the disproportionately large gonads of fishes. Jordan (1926) describes coarse granulocytes with basophilic and eosinophilic granules in the gonads of elasmobranchs (e.g. skate).

Liver. The liver provides an illuminating example of the minor differences in distribution of the 'lymphoid tissue' in a single organ within a group of closely allied animals. According to Drzewina lymphoid tissue is greatest in the livers of urodeles, least in many frogs and toads. It is absent from the livers of adult birds and mammals though present there during embryonic life (Dantschakoff, 1916). In some species of Ichthyopsida the simple perivascular cuffs, as in ganoids, undergo hypertrophy cortically or centrally in the liver to form comparatively large masses of tissue. Oppel (1889) was the first to describe the thick 'couche corticale' of lymphoid tissue beneath, but not attached to, the hepatic serosa of the primitive urodele 'Proteus anguineus'. Drzewina found a similar arrangement in the liver of the terrestrial salamander and believes this layer to be made up of the fused perivascular cuffs of numerous cortical blood vessels. Similar vagaries in distribution will be noted when the location of mast cells in the livers of higher vertebrates is examined.

There is some experimental evidence that the extent and activity of the lymphoid tissue of Ichthyopsida are influenced by the nutritional state of the organism and that a compensatory increase in activity of this tissue follows splenectomy (Drzewina, 1905; Ohuye and Ochi, 1954). 
Relationship OF MAST CELls to EOSINOPHILS. Before leaving the subject of the mast cells in the lower vertebrates we may briefly consider the views of Jordan and his school on the relationship of mast cells to eosinophils in blood and tissues. This is particularly necessary since Jordan's conclusions at first appear to be in conflict with those of most other workers in this field.

In his earlier studies on blood formation in reptiles (Jordan and Flippin, 1913) and amphibia (Jordan, 1919) Jordan adopted a conventional outlook and regarded the mast cell as a specific variety of granulocyte distinct from and genetically unrelated to the eosinophil. The distinction is clear, even in many arthropods: in certain crayfish, for example, eosinophils stem from a highly localized tissue ('orgagne globuligène' of Cuenot, 1905) whereas, as we have seen, the metachromatic basophils in the crayfish are of widespread perivascular origin (Hardy, 1892). Later, however, Jordan and Speidel (1924a) failed to find basophils in certain fish but were impressed by the abundance of irregular amoeboid eosinophils in the gut wall of the teleostean scup and tautog. Similar conditions apparently obtained in a reptile, the terrestrial salamander (Jordan and Speidel, 1924b). On reviewing their data in the light of an earlier study of blood formation in the frog (Jordan and Speidel, 1923), these authors conclude that the eosinophils arise from lymphocytes or undifferentiated connective tissue cells and that the remaining cells with basophilic granules are either 'unripe eosinophils' or, if the granules are bulky, irregular and metachromatic 'eosinophils in course of degeneration'. According to Jordan and Speidel (1923) such 'abortive eosinophils' are common in the spleen of the bullfrog. Meanwhile Michels $(1922 ; 1923)$ had studied the dense accumulations of granular cells in the tissues of many lower vertebrates and had concluded that morphologically and from their connective tissue habitat such cells are to be regarded as mast cells. Nevertheless, Jordan (1926, p. 99) insists that 'the granulocytes described and illustrated by Michels in various fish tissues, stained metachromatically red with thionin and interpreted by him as mast cells, are apparently strictly homologous with very similar cells occurring in the gut wall of the scup and tautog (Jordan and Speidel, 1924a) where they are definitely oxyphilic; and with those in the intestines of the leopard frog where they are distinctly metachromatically basophilic. They are apparently identical also with the tissue eosinophils which differentiate in the connective tissue of the intestinal submucosa, and with the eosinophilic and special granulocytes which develop in large part from the reticular cells in the peripheral area of the femoral marrow of the rabbit; and with comparable cells with a similar origin in the subcapsular region of the liver of the salamander, and in the capsule and septa of the ovaries and testes of the skate' .... Apparently, then, he goes on (p. 104), 'the so-called mast cells include three varieties: initial orthobasic granular progenitors of eosinophils, ripening metachromatic eosinophils, and 
abortive or degenerating metachromatic eosinophils'. Thus in Jordan's view (p. 103) 'metachromaticity of staining reaction is a phase of the ripening process of the eosinophil granule. This is a novel conception of the metachromatic granule, as distinct from the orthobasic granule, but the evidence seems to permit of no escape.'

Novel as this conception may be, it must be conceded that there are few who would agree with Jordan that metachromatism in the granules of connective tissue cells implies either that the cells are degenerating eosinophils or that they are eosinophils which are ripening so slowly that they will now never achieve maturity. A mere glance at a suitably stained tissue spread from many higher animals is enough to shake such a belief. In rodents and cattle the connective tissues are often packed with cells filled with basophilic or basophilicmetachromatic granules, whereas eosinophils may be entirely lacking. Indeed, it might be as plausibly argued from Jordan's data that it is the metachromatism of the granules which signifies that the cell has reached full maturity and that any subsequent eosinophilic staining is a sign of degeneration; certainly this concept would be more in agreement with the findings of Kollmann (1908) and Kindred (1926) on the 'amoebocytes with spherules' in invertebrates and with the work of others who have subsequently examined the granular cells in fishes (Romieu, 1924; Bolton, 1933; Duthie, 1939). However, there are great difficulties in interpreting the histological appearances shown by the granular cells in fishes, especially the cells in the wall of the gut. As Al-Hussaini (1949, p. 334) remarks "the picture is still further complicated by the fact that the number of granules which are stainable by one technique may be quite different from that seen with a different one, even in one and the same fish. ... This suggests that even in one species the granules may be of differing chemical composition and hence may have several functions to perform.' Most modern workers agree with Ehrlich (1878) that the mast cell is a cell 'sui generis', generically and functionally different from the eosinophil. It is true that eosinophils often occur along with mast cells in pathological conditions in higher vertebrates but there may be another explanation for this.

To sum up. Mast cells or their homologues are demonstrable in the tissues of many invertebrates and lower vertebrates, and the sites at which these cells are found in relation to the more general problem of blood formation suggests an explanation for the presence of mast cells in marrow and tissues. The gradual withdrawal of much of the original haemopoietic tissue into the bone marrow, and the enclosure of the progenitors of the lymphocytes in nodes and spleen, still leaves at the sites of former haemopoietic activity a scattered residuum of what Maximow $(1924$; 1926) has called "undifferentiated mesenchymal cells'. One possible line of development of these cells is the tissue mast cell. 
Higher vertebrates, INCLUding Man. Ehrlich (1877) and his pupil Westphal (1891) found tissue mast cells to be numerous in cat, dog, goat, rat, bat, and calf; rare in rabbit, hare, and guinea pig. Later, Zimmermann (1908), using the excellent histological technique devised by his colleague Schaffer (1907), showed that tissue mast cells are rather more common in the guinea pig than Ehrlich believed and that they occur at the usual sites for mast cells in mammals, namely in loose connective tissue generally and especially around blood vessels, between fat cells, in peritoneum, in most organ capsules and in the thymus. The guinea pig also resembles other mammals in that mast cells are absent from the central nervous system. According to Krabbe (1928) the hedgehog alone among the mammals has mast cells within the substance of the brain, the cells being particularly common in the habenular ganglion. There is general agreement with the findings of Ehrlich and Westphal regarding mast cells in the other species which they examined. Much of our knowledge of tissue mast cells in the embryonic and adult forms of higher vertebrates is due to the painstaking studies of Maximow $(1906 ; 1910 ; 1913 ; 1924)$ who strengthened and expanded the views of Ehrlich and Westphal and dealt summarily with their critics.

In his thesis Westphal (1891) mentions the variations in size of the granules in mast cells of different species. Comparatively coarse in rat, mouse and guinea pig the granules are small in birds and dust-like in amphibia. The name 'mast cell' as defined by Ehrlich $(1878 ; 1879)$ is thus now more appropriate for the cells with basophilic metachromatic granules in the higher vertebrates than is the term 'coarse granulocyte' which we found convenient for describing the homologues of mast cells with variable staining properties in the tissues of lower organisms.

Minor differences in distribution of mast cells are found in mammals as in lower vertebrates, the liver again providing a good example of the variation in the mast-cell pattern among related species. Thus the cells are exceptionally large and numerous in the capsule of ox liver (Holmgren and Wilander, 1937), whereas in the liver of the dog they are small and are found near the portal tracts and scattered diffusely throughout the liver parenchyma (Nagayo, 1928). In contrast to the high mast-cell content of the liver in ox and dog the liver in rabbit and rat is almost devoid of mast cells (Westphal, 1891). Holmgren and Wilander (1937) describe in detail the presence and distribution of mast cells in liver, spleen and lung of cow, calf, sheep, horse, pig, dog and rabbit. Corresponding data for mast cells in the gut of several species of mammals are to be found in the paper by Mota, Ferri and Yoneda (1956) and in the early investigations of Hardy and Wesbrook (1895) who emphasize the enormous numbers of 'splanchnic basophils' in the submucosa of carnivora. Arvy and Quivy $(1955 a, b)$ describe in detail the distribution of mast cells in the alimentary tract 
of the dog. However, for present purposes it is probably more instructive to examine the origin and distribution of tissue mast cells in a limited number of higher vertebrates than to compile a catalogue of the minor variations which have been recorded. We shall therefore examine briefly conditions in rat and man. For references to mast cells in other species the reader is referred to the comprehensive review of the literature by Michels (1938).

Mast cells of the rat. The careful studies of Maximow (1910) and Alfejew (1924) indicate that tissue mast cells are first recognizable in the early embryo of the rat as small lymphoid-like cells with few granules and arise either from fixed mesenchymal precursors or from basophilic non-granular wandering cells which settle down and undergo differentiation in the loose subcutaneous and intramuscular connective tissues of the head and neck. Mast cells appear somewhat later than the other granulocytes and at first multiply heteroplastically, later by homoplastic mitotic division. By the end of intrauterine life the topographical distribution of the tissue mast cells has spread to include all the loose connective tissues (Laguesse, 1919; Urtubey, 1948; Arvy, 1956b). Webb (1935) states that the number of mast cells in the dermis of the white rat increases tenfold from 5 days before to 19 days after birth, the count then dropping slightly and remaining constant up to the fifty-first day. A sharp increase in tissue mast cells up to the tenth day was also noted by Fish (1949). Bates (1935), however, records a slight but progressive fall in the number of tissue mast cells from birth onwards to 78 weeks with concomitant increase in the number and size of the granules in the cells that remain. The cells are common in the serous membranes and can be recovered in small yield from the peritoneal fluid (Webb, 1931; Padawer and Gordon, 1955).

Mast cells are rare in the parenchymatous organs of the rat in contrast to their great abundance in connective tissue and peritoneum. Lungs, spleen, liver and kidney are virtually devoid of mast cells. However, they are by no means uncommon in the oesophagus and in the forestomach, where they appear to arise chiefly from precursors around the deeper vessels and, on occasion, to migrate up to and even through the mucosa (Sansonow, 1909; Cambel et al, 1952). They are comparatively rare in the rest of the alimentary tract (Arvy, 1956b; Mota et al, 1956).

There are no mast cells within the brain substance of the rat, though they are common in the meninges (Waldeyer, 1875) and in the sheaths of peripheral nerves (Riley, 1953a; Riley and West, 1955a; Padawer, 1957).

Mast cells in man. Mast cells appear late in the human embryo as in other species (Ehrlich, 1877; Holmgren, 1946; Kitanishi, 1956). During the course of intrauterine life small cells containing a few metachromatic granules are seen at sites of extramedullary haemopoiesis and in organs which are well developed before birth, e.g. liver and gall bladder, eye, heart muscle and vessels, 
later in all the subcutaneous connective tissue. Staemmler (1921) emphasizes the high mast-cell content of the developing thymus. Meanwhile, a generalized metachromasia of the connective tisue is fading (Holmgren, 1939, 1940; Bairati and Bianchini, 1953; Hjelmman, 1954; Kitanishi, 1956), although, as is well known, metachromasia persists and is an outstanding feature of the Wharton's jelly of the umbilical cord.

Numerous investigators have studied the development and distribution of mast cells in the umbilical cord, seeking a possible relationship between the diffuse metachromasia of Wharton's jelly and the compact, granular metachromasia of the mast cells (Lehner, 1924; Pescetto, 1950; Sundberg et al, 1954; Moore, 1956). Mast cells appear much later than the Wharton's jelly, which is itself non-metachromatic when it is first laid down in utero: later the two types of metachromasia-diffuse and granular-can be distinguished by their differing reactivity to certain enzymes (Moore and Schoenberg, 1957a and $b$ ). Schoenberg and Moore (1958) have recently suggested that a simple carbohydrate precursor elaborated by the fibroblast undergoes further construction in the tissue spaces, a type of extracellular synthesis now known to occur around certain micro-organisms (Markowitz et al, 1958). I have suggested that a final alteration and storage of high-molecular sulphated mucopolysaccharide occurs in the mast cell (Riley, 1954, 1955). This would accord with the finding of Hopf (1952) that mast cells often become very numerous in the stump of the cord and adjacent peri-umbilical skin during the immediate neonatal period. At this time small mast cells, rather poor in granules, are demonstrable at sites in which mature cells are found in later life (Audrey, 1896).

In the adult, mast cells are common in all loose subcutaneous and submucous connective tissue (Harris, 1900; Staemmler, 1921). They occur frequently in the connective tissue of the female breast (Higuchi, 1930) and in the intermuscular connective tissue of uterus, bladder and even the tongue (Raudnitz, 1883; Staemmler, 1921): indeed, they are common in the tongue of most species (Westphal, 1891; Clowes and Owen, 1904). In the skin itself the cells occur mainly near hair follicles, glands, small blood vessels (Ehrlich, 1878; Schwenter-Trachsler, 1906; Staemmler, 1921; Sylvén, 1941) and between fat cells (Hissard et al, 1950b), tending, as Ehrlich so clearly pointed out in his thesis (1878, trans. p. 87) 'to concentrate around the preformed structures which traverse the connective tissue'.

In the gut the mast cells are situated chiefly in the villi, around the necks of the duodenal glands of Lieberkühn and scattered throughout the submucosa of the small intestine and caecum (Westphal, 1891; Hardy and Wesbrook, 1895; Sansonow, 1909).

The perivascular habitat of the mast cell is so characteristic as to pass almost without comment. Greggio (1911) and Quensel (1928) stress the presence of 
mast cells around capillaries; Neumann (1885) and Staemmler (1921) saw them more frequently around small arterioles and venules. Jorpes, Holmgren and Wilander (1937) describe mast cells around the vessels of the choroid and at the limbus of the eye. In a statistical survey of mast cells in the adventitia of the larger blood vessels Sundberg (1955) found a rise in mast-cell content up to middle life, most marked in the aorta, followed by a decisive fall, especially in the walls of the large veins.

The central nervous system of man resembles that of most other species in lacking mast cells (Harris, 1900; Squartini and Giacanelli, 1956) though they occur in the meninges (Rosenheim, 1886) and even in connective tissue around the vessels of the choroid plexuses (Tsusaki, 1951) and pituitary stalk (Gray, 1935; Consolandi and Briziarelli, 1952). Outside the central nervous system the cells are comparatively common in the sheaths of peripheral nerves (Henschen, 1928) though rare in and around autonomic ganglia (Hermann, 1952).

The general conclusion to be drawn from this preliminary survey of the distribution of the mast cells in man and in the rat is that they are, as Ehrlich stated, cells of the loose connective tissue. As Staemmler (1921) points out, their presence in a parenchymatous organ can usually be accounted for by its connective tissue content, the exceptions, apparently, being thymus and, to a lesser extent, lymph nodes in which the mast-cell content increases with hypertrophy of the parenchyma. The special relationship of the mast cells to the lymphoid tissue has been considered above: further examples of the association of mast cells with connective tissue and its possible significance will be discussed when the mast-cell content of pathological tissues is examined. Meanwhile, we may complete our survey of the normal organism by reviewing briefly the second type of mast cell in the vertebrates, the blood mast cell, basophil or mast leucocyte. 


\section{Chapter III}

\section{THE BLOOD MAST CELL, BASOPHIL OR MAST LEUCOCYTE}

$\mathrm{E}$ XAMINATION of suitably fixed and stained preparations of the blood of vertebrates shows a minority of the leucocytes to contain basophilic metachromatic granules in their cytoplasm. These are the blood mast cells or mast leucocytes and have been described in reptiles (Loewenthal, 1930; Ohuye, 1952), fishes (Michels, 1923; Loewenthal, 1930), birds (Forkner, 1929) and in many other vertebrate species (Ponder et al, 1928, 1929; Knoll, 1932). The chief morphological features which distinguish the mast leucocyte from the tissue mast cell are its smaller size, more rounded shape, its relatively scanty cytoplasm and the decidedly polymorphous character of its nucleus (Harris, 1900), differences which the cells retain even though they leave the blood stream and enter the tissues (Zimmermann, 1908; Ringoen, 1923). Like the tissue mast cells, the mast leucocytes were first clearly described by Ehrlich.

It was not Ehrlich's habit to linger over his discoveries. In his 'Farbenanalytische Untersuchungen' of 1891-forerunner of modern texts on haematology - the chapters on tissue mast cells and on eosinophil leucocytes are already handed over to his colleagues, Westphal and Schwartze. Meanwhile Ehrlich (1891, p. 58) had discovered basophilic granular cells in human blood, though so far only in myeloid leukaemia. Nevertheless, with characteristic insight he at once perceived that the blood mast cells in higher vertebrates are true leucocytes stemming from precursors in the bone marrow. By the time that his textbook came of 1898 to be revised (Ehrlich and Lazarus, 1909) the evidence for the myeloid origin of the blood mast cell was complete (Jolly, 1900).

It was thus all the more curious that the rival school of haematology led by Pappenheim should criticize Ehrlich's views on blood mast cells without checking the findings by the use of Ehrlich's own methods. As Michels (1938) points out, the controversy which developed hinges on the interpretation of findings obtained with inadequate histological techniques. Unfortunately for Ehrlich's critics the two situations in which blood mast cells are common, namely the blood of the normal rabbit and leukaemic blood in man, are precisely those situations in which the mast granules are most water-soluble, lending themselves readily to the production of artifacts during fixation and staining (Westphal, 1891; Michaelis, 1902; Piette, 1955).

We have already reviewed the evidence of Jordan (1926) who, nearly twenty years later, argued in favour of the degenerative character of the tissue mast cell. With even less justification Pappenheim (1909) and his conteinporaries 
Weidenreich (1908) and Pröscher (1909) came to regard the blood mast cell as a degenerative lymphocyte, the cytoplasmic bodies being alleged to represent nuclear extrusions or a mucoid degeneration of the protoplasm. Thereafter, Pappenheim's pupils, Bennachio (1911), Kardos (1911) and St. Szécsi (Pappenheim and St. Szécsi, 1912), persistently failed to find precursors for the blood mast cells in the marrow of guinea pig and rabbit, ignoring completely the excellent point made by Ferrata (1912) in his book, that a high basophil count occurs in man in chronic myeloid leukaemia, not in chronic lymphatic leukaemia as it should if the theories of Pappenheim and Weidenreich were valid.

Outstanding in this period of confusion over the identity of the blood mast cell is the high quality of the contributions of Maximow of St. Petersburg. Maximow (1906) had previously stressed the abundance of mast cells in the blood of the rabbit in contrast to the paucity of its tissue mast cells (Westphal, 1891). Four years later Maximow (1910) returned to this subject and presented substantial evidence not only for the myeloid origin of the blood mast cells in the rabbit but also for a similar origin of the mast leucocytes in guinea pig, cat and rat. In 1913 he and Downey simultaneously published papers calculated to end the controversy for any impartial observer. Maximow reviewed his previous evidence, added fresh findings regarding the mast leucocytes in the dog and searched normal marrow in man with such persistence that eventually he was able to depict mast myelocytes in mitosis. The results of Downey's research on the guinea pig led him to declare with like conviction (p. 137) that, providing an adequate histological technique is used, 'the mast leucocytes of the animal are so definite and characteristic that they can be identified from the moment of their first appearance in the bone marrow'. Finally, Downey's pupil, Ringoen $(1919,1923)$, using a fixative actually introduced by one of Pappenheim's own students, St. Szécsi (1913), corroborated the myeloid origin of the mast leucocytes in both rabbit and guinea pig, the accumulated evidence of the period being critically evaluated by Maximow (1924).

In his summary Maximow (1924) reviews the status of the blood mast cell throughout the evolutionary scale, pointing out as we have already observed in discussing the tissue mast cell that it is only with the evolution of the bone marrow that partition occurs in the production of mast cells. The mast cells of lower organisms are derived from cells of the fixed mesenchyme or from undifferentiated circulating precursors which lodge in the tissues and there elaborate their characteristic granules (cf. Kollman, 1908; Michels, 1923; Wigglesworth, 1956). Tissue mast cells in higher organisms continue to arise and to remain in the old haemopoietic centres and a new type of cell, the mast leucocyte develops in parallel with the other members of the myeloid series and, with them, finds its way from the marrow into the blood stream. In 
Maximow's words (p. 544), 'whereas in the lower vertebrates the connective tissue mast cells are intimately related to the basophilic blood leucocytes and may originate from them through direct transformation after emigration out of the blood vessels, the mast cells and the mast leukocytes of the mammals seem to be independent cell types'. This independence is well shown in the experiments of Ringoen (1923) who induced a mast leucocytosis in the guinea pig by a subcutaneous injection of egg white and found that although blood mast cells may then migrate into the tissues the cells promptly undergo dissolution: Zimmermann (1908) likewise experienced no difficulty in recognizing extravasated blood mast cells in the guinea pig. The individuality of blood and tissue mast cells and their separate origin and habitat in higher vertebrates are thus clear.

However, as Maximow (1910) observed, there does appear to be a certain degree of reciprocity between the numbers of blood and tissue mast cells in various species, suggesting perhaps that both types of cell subserve the same biological function. Thus, among the mammals, blood mast cells preponderate in the rabbit, whereas in rat, mouse and most other species the tissue mast cells far outnumber the mast cells produced by the marrow. Michels (1923) found the tissues of certain species of fish to contain 'an incomparable abundance' of mast cells. His statement that mast cells are entirely lacking in the blood of fishes has been criticized by Loewenthal (1930), though the numbers of blood mast cells in fish are never large. The proportion of mast cells in human blood remains remarkably constant at $0 \cdot 5-1 \cdot 0$ per cent of all leucocytes and is not affected by local increase in tissue mast cells (Heller, 1904; Pappenheim, 1909; Staemmler, 1921; Ellis, 1949). These small values are perhaps best expressed as the absolute basophil count, the number of cells per c.mm. blood (Moore and James, 1953). A raised basophil count is a regular feature of chronic myeloid leukaemia (Ehrlich, 1891; Heller, 1904; Holmgren and Wohlfart, 1941) and tends to remain high even after the polymorph count has been reduced by irradiation (Sabrazès, 1926). True basophilic leukaemia in man is extremely rare (Joachim, 1906; Doan and Reinhart, 1941; Hule, 1950; Lennert et al, 1956). Very recently two cases of so-called tissue mast-cell leukaemia have been reported (Efrati, et al, 1957; Friedman et al, 1958).

\section{Tissue mast cells in bone marrow}

In addition to the mast myelocytes which produce the blood mast cells, an occasional tissue mast cell is seen in smears or sections of human bone marrow, being easily recognized by its large size and dense content of darkly staining metachromatic granules. According to Jordan and Speidel (1924a) tissue mast cells are comparatively common in the subcortical region of the femoral marrow of the normal rabbit, and one has seen them in small numbers 
in this situation in the normal rat. A few tissue mast cells are always present in the investing layer of periosteum which more closely resembles fibrous tissue elsewhere.

Many haematologists have observed, as a rare event, an increase in the number of tissue mast cells in the bone marrow of man and have sought to endow the finding with diagnostic or prognostic significance. Undritz (1946), Leitner (1949) and Bremy (1950) record such an increase in cases of aplastic anaemia; Messerschmitt (1954) found them regularly in the marrow of patients suffering from chronic blood loss. Bremy (1950) concludes his monograph with the suggestion that not only does an increase occur in patients with aplastic anaemia, but also in cases of anaphylaxis, and that the chief underlying cause is a reticulosis affecting the bone marrow. Both he and Fadem (1951) consider the possibility that the mast cells are the cause of the depressed haemopoiesis. However, Johnstone (1954), in a re-examination of the problem, failed to find any significance, diagnostic or prognostic, in the occasional appearance of tissue mast cells in the bone marrow of man, though he acknowledges that the highest content seen by him was in a case of Banti's splenomegaly. Johnstone makes the interesting observation that the tissue mast cells in the marrow generally lie at the periphery of small nodules of lymphoid cells, much as they are related to nodules of non-encapsulated lymphoid tissue in the gut wall of cattle (p. 45) and to the 'milk spots' in the omentum of the rat (Webb, 1931). It was noted earlier that tissue mast cells are not common in capsulated lymph nodes (Holmgren, 1946).

The writer is inclined to agree with Williams (1952) and de Viñals (1954) that, in all probability, tissue mast cells in bone marrow have much the significance that they have elsewhere, being a normal component of the connective tissues (Riley, 1954). Hence, if the connective tissue framework of the bone is proliferating, as in the reticuloses, or if the haemopoietic marrow is reduced, as in aplastic anaemia, then local conditions favour an increase in tissue mast cells.

Two pathological conditions affecting the long bones of rats have recently been described which support this view. In the first, a triple syndrome of decalcification-rickets-osteitis fibrosa is associated with fibroplasia in the metaphysis (Urist and MacLean, 1957). The second is the lathyrus syndrome in which there is distortion and remodelling of the shaft (Gillman, 1958). A mastocytosis develops in the zone of abnormal fibroplasia in each case. 


\section{CHAPTER IV}

\section{MAST CELLS IN PATHOLOGICAL CONDITIONS}

$\mathrm{T}$ study the presence and significance of mast cells in pathological states is again to acknowledge our debt to the pioneer observations of Ehrlich (1878) who, it will be remembered, chose the name "Mastzellen' following his observation that the cells are more numerous where the local nutrition of the connective tissues appears to be enhanced.* Ehrlich (1879) describes two situations where connective tissue may be overnourished, in chronic inflammation and the environs of tumours. Here, he infers, there exists a lymph stasis, a damming up of tissue fluid rich in nutriment, whereby certain fixed connective tissue cells are stimulated to become mobile, to multiply and to convert some of the abundant extracellular material into specific intracellular granules-a process of 'mästung' or fattening (the German root is still preserved in such English words as beech 'mast' and 'mastication'). According to Ehrlich (1879) the mast cells are 'indices of the nutritional state of the connective tissue', increasing during periods of hypernutrition, diminishing during periods of relative starvation. And it must be admitted that all the research work of the past seventy-five years has failed to displace entirely this original hypothesis of the function of the mast cell in relation to the connective tissues.

\section{Mast cells and inflammation}

Ehrlich was careful to point out that a local increase in the mast cell population occurs only in chronic inflammation. Mast cells are thus common in chronic paronychia (Bäumer, 1896), in chronic gingivitis (Todoro, 1938) and in other situations where fresh connective tissue is being laid down (Staemmler, 1921), even though the normal organ might originally be poor in connective tissue and lacking in mast cells, as in brain (Neumann, 1885; Baeckeland, 1950), thyroid (Blomquist, 1956) and kidney (Baar and Bickel, 1952). In comparing normal and diseased organs Janes and McDonald (1948) regularly observed an increase in the number of mast cells in chronic inflammatory conditions of joints, appendix, gall bladder, breast, uterus, prostate and other organs and tissues in which there is fibrosis. Mast cells are thus commonly seen in the granulomatous lesions of syphilis, tuberculosis (Harris, 1900) and regional ileitis (Trincão, 1953). Increased numbers of mast cells have also been

* Ehrich's 'Mastzellen' are variously described by later investigators as 'cellules isoplastiques ', 'cellules à l'engrais', 'mastocytes', 'cellulas cébadas', etc. Among modern workers, Arvy (1955d) still prefers the term 'labrocyte', once favoured by Michels (cf. Michels, 1938, footnote p. 251, and discussion to Arvy, 1955b, pp. 222-223). 
described in chronically infected or hypertrophied nerve sheaths (Rosenheim, 1886; Unna, 1894; Greggio, 1911), in fibrotic adrenals (Sabrazès and Husnot, 1907), in rheumatic myocarditis (Hamilton and Syverton, 1950) and are particularly numerous at the base of chronic peptic ulcers (Quensel, 1928; Janes and McDonald, 1948; Corbetta, 1951; Squartini et al, 1956). They are frequently seen in chronic inflammatory conditions of the skin (Asboe-Hansen, 1950; Prakken and Woerdemann, 1952). Both Ehrlich (1879) and Westphal (1891) were impressed by the abundance of mast cells in 'brown induration' (haemosiderosis) of the lung. However, they and many later authors agree that in acute inflammation the mast cells temporarily disappear (Neumann, 1890; Neuberger, 1894; Maximow, 1904; Ernst, 1926; Stockinger, 1927; Brodersen, 1928; Quensel, 1933; Larsson and Sylvén, 1947; Drennan, 1951; Gustafsson and Cronberg, 1957; McGovern, 1957). Later, as the acute inflammation subsides and as spindle-shaped fibroblasts elaborate their fibrils, there occurs a progressive increase in the number of mast cells in the affected area; and as long as this proliferative phase persists the local mast-cell population continues to increase (Staemmler, 1921; Bensley, 1950). Enormous numbers of mast cells are thus found in the hypertrophied connective tissue of elephantiasis (Bäumer, 1896; Ehrich et al, 1949). Once healing is complete the local hyperaemia subsides and the fibrous tissue becomes progressively less cellular, finally dry and sclerotic. As it does so the local mast-cell population likewise declines until, in dense scar tissue, no mast cells remain (Ehrlich, 1877; Neumann, 1890; Bäumer, 1896; Staemmler, 1921; Higuchi, 1930). This sequence of events, seen in the connective tissues of the healing wound (Maximow, 1904; Sylvén, 1941; Numers, 1953; Wichmann, 1955), becomes even more obvious during the life cycle of keloid (Pautrier and Woringer, 1931; Sylvén, 1941, 1945; Asboe-Hansen, 1951).

Examination of the status of the mast cell in the inflammatory process thus supports Ehrlich's view that there appears to exist a functional association between the mast cell and connective tissue, increasing fibroplasia merely emphasizing a relationship which we have already noted in our study of the mast cell in the normal organism (Riley, 1954).

\section{Mast cells and tumours}

Four aspects of the relationship of mast cells to tumours can be distinguished. They are:-

1. the mast-cell reaction to established tumour growth;

2. tumours rich in mast cells;

3. tumours composed of mast cells;

4. the mast cell in carcinogenesis. 
1. Mast-Cell Reaction to tumours. Ehrlich (1879) records that he found many mast cells in tumours, 'especially carcinoma', but it was left to his pupil, Westphal (1891), to recognize that the cells tend to congregate chiefly at the periphery of carcinomatous nodules rather than within the substance of the tumour. Westphal (p. 40) states that 'especially around rapidly growing carcinomas the mast cells accumulate in unprecedented numbers' ("in colossaler Menge'). This predilection of mast cells for the environs of tumours has repeatedly been confirmed both for spontaneous tumours(Unna, 1896; Fromme, 1906; Bonney, 1908; Weill, 1919; Staemmler, 1921; Higuchi, 1930; Quensel, 1933; Michels, 1938; Sylvén, 1940; Bali and Furth, 1949) and for experimentally induced new growths (Bierich, 1922; Peyron, 1923; Fabris, 1927; de Viñals, 1931; Cramer and Simpson, 1944; Holmgren and Wohlfart, 1947). Sylvén (1945) in particular has studied the distribution of metachromatic "free chromotrope substance' and the disposition of mast cells in and around mesenchymal tumours. According to Sylvén the process of tumour invasion is preceded by the conversion of the adjacent normal connective tissue into a gelatinous matrix rendered metachromatic in part by the release of granular material from tissue mast cells. In slowly growing mesenchymal tumours the preliminary process of digestion of the normal tissue so far outstrips the subsequent utilization of this 'free chromotrope substance' that the tumour is seen to be surrounded by a vivid band of diffuse metachromasia, whereas in more anaplastic growths the metachromatic zone is consumed as fast as it is formed. However, Sylvén (1945) himself records that in keloid the generalized metachromasia is strongest during the period of most active growth, mast cells appearing later as the 'free chromotrope substance' is fading and differentiation is setting in. It has yet to be shown that the metachromasia of 'free chromotrope substance' and of mast cells are histochemically identical, or are even causally related (Holmgren and Wohlfart, 1947; Riley and Drennan, 1949; Favilli, 1950).

There is a second way in which mast cells may be concerned in the growth of an established tumour, namely through the ability of a tumour, especially an epithelial tumour, to induce for itself an internal stroma of blood vessels and fibrous tissue. Several authors have noted that in slowly growing scirrhous carcinomas the relatively abundant and well differentiated stroma usually contains an appreciable mast-cell content (Bäumer, 1896; Harris, 1900; Williams, 1900; Clowes and Owen, 1904) whereas in more anaplastic tumours the stromal mast cells are few and poor in granules (Regaud and Lacassagne, 1922; Higuchi, 1930; Holmgren, 1946).

Consideration of the foregoing data suggests that the accumulation of mast cells around the growing edge of tumours and the presence of mast cells within the stroma of slowly growing neoplasms both reflect charges in the 
connective tissues, invasion of normal tissues favouring the development of mast cells, other mast cells arising as fresh connective tissue is laid down within the tumour itself.

2. Tumours RICH IN MAST CELls. Certain tumours appear to have a characteristically high mast-cell content irrespective of the state of their stroma or of the accumulation of mast cells at the periphery, though there is nothing to suggest that the mast cells themselves are malignant. In view of what has already been said concerning the normal habitat of the mast cell in relation to fibrous tissue and blood vessels, it is not surprising to find the cells in simple fibromas and angiomas (Bäumer, 1896; Harris, 1900). Numerous mast cells have also been observed in the skin lesions of neurofibromatosis (Unna, 1896; Greggio, 1911; Cornil and Michon, 1924).

So far as frankly malignant tumours are concerned Holmgren and Wohlfart (1947) report an interesting experimental study of mast cells in chemically induced fibrosarcomas in rats, the cells being numerous in fibroplastic tumours, less common in more cellular growths. Within the substance of the tumours the mast cells are scattered diffusely among the malignant fibroblasts, and though the tumours are often rich in blood vessels, perivascular mast cells are comparatively rare. Serial transplantation of fibroplastic sarcoma rich in mast cells led to the emergence of more cellular growths and, as this transition occurred, the mast-cell content of the tumours declined. Other significant observations in this study are first, that mast cells are always numerous at the periphery of the tumours irrespective of their internal mast-cell content; secondly, that no correlation whatsoever was seen between the density of the mast-cell population and the presence or absence of 'free chromotrope substance' as described by Sylvén. Holmgren and Wohlfart conclude (p. 689) that 'the most likely assumption appears to be that the mast cells develop locally in the connective tissue of the tumours', a suggestion which is in line with the observations which we have already made in our examination of the mast cell in chronic inflammation. I have confirmed many of the above findings in a series of uterine fibroids and fibrosarcomas in women.

Of great interest, therefore, are the non-fibroblastic tumours rich in mast cells discovered in inbred mice by Bali and Furth (1949). The first is a transplantable splenic tumour composed of polygonal epithelium-like cells "thought to be derivatives of splenic reticulum' and often containing erythropoietic foci and large accumulations of mast cells. According to these authors (p. 607) the mast cells were always numerous, "in the "capsule" of the tumour and were abundant about the connective tissue stroma and about the adventitia of vessels', characteristics which the tumours retained on transplantation. It is noteworthy that growth on transplantation was extremely slow, often requiring up to six months for a nodule to become palpable. 
The second tumour, a luteoma, contained even more mast cells than the splenic tumour; here again the mast cells were chiefly associated with the connective tissue stroma although (p. 616) 'transplantable luteomas characteristically rich in mast cells were relatively poor in connective tissue'. In addition, some of the luteoma cells displayed a diffuse metachromasia of their cytoplasm.

In contrast to both the splenic tumour and the luteoma was granulosa cell tumour which contained no mast cells though they were often present in the peritumoral tissues. Thus, whatever may be the reason for the high mast-cell content of the splenic tumour and the luteoma it cannot be explained simply on the presence or absence of stroma, despite the fact that mast cells, when present, tended to be related to the connective tissues. It seems that certain tumours are capable of stimulating the development of mast cells though the precise reasons for this are not clear.

3. TuMOURS COMPOSED OF MAST CELLS. Rarely a tumour is discovered which is itself composed of mast cells. Among the most striking examples of local aggregations of mast cells in pathological states are the skin lesions of urticaria pigmentosa, discovered by Nettleship (1869) and beautifully described in his book by Unna (1896). The skin manifestation of urticaria pigmentosa consists of a dense collection of mast cells distending the papillary body and causing thinning and elevation of the overlying epithelium, the prickle cells of which are pigmented. The mast cells extend into the dermis as columns of cells separated by blood vessels and collagen: very occasionally the regional nodes are enlarged and contain mast cells. On irritating a lesion the papule swells and may even form a blister localized to the pigmented area while the surrounding skin shows more or less erythema. Typically the lesions are small and multiple and tend to disappear spontaneously about the time of puberty, although occasionally the disease makes its first appearance in adult life. Clearly, this is not a malignant tumour in the accepted sense, though it may well belong to the group of reticuloses (Cazal,1942; Sagher, 1956; Marshall et al, 1957; Nickel, 1957; Remy, 1957).

So far as the writer is aware only one case of true mast-cell tumour in man has been recorded (Hissard, Moncourier and Jacquet, 1950a). A forty-oneyear-old male developed numerous partly fixed and ulcerating skin tumours over the abdomen and buttocks; both liver and spleen were palpable. Biopsy of a skin lesion showed it to consist almost entirely of mast cells and blood vessels. The blood picture was normal except after splenic puncture or the injection of adrenaline when mast cells temporarily entered the circulation. In a more detailed account of the histology of this case, Hissard, Moncourier and Jacquet (1950b) describe the origin of the tumour mast cells from dermal precursors and believe that the cells migrate towards the epithelium where they undergo lysis. 
Two types of mast-cell tumour have been reported in mice. The first consists of single or multiple nodules in the skin of mice which have been painted with a carcinogen, one such tumour (the ' 3187 transplantable mastcell sarcoma') proving sufficiently autonomous to be carried as a transplant for several generations before it eventually died out; a more recent tumour is still available (Dunn and Potter, 1957). A similar transplantable mastocytoma has been derived from a mouse subjected to ionizing radiation (Furth et al, 1957). The second type, more properly described perhaps as a diffuse mastocytosis, is seen occasionally in old Strain A mice in which mast cells infiltrate the internal organs, especially the spleen. In discussing the aetiology of the condition Deringer and Dunn (1947) record that a high mast-cell content of the spleen appears to be a common feature in old mice of this strain.

Spontaneous single or multiple mast-cell tumours are by no means uncommon in certain domestic animals (cf. Head, 1953). Sabrazès and Lafon (1907) describe a tumour consisting predominantly of mast cells and eosinophils which appeared on the lip of a horse following injury. Sabrazès, Muratet and Antoine (1908) also record a pigmented tumour on the eyelid of a cat whose spleen was distended with mast cells and plasma cells. We have recently had the opportunity of examining several types of mastocytoma in domestic animals, including a cow with multiple mastocytomas of the skin (Head et al, 1959, and see Chapter X).

Subcutaneous mast-cell tumours are seen most frequently in dogs (Bloom, 1942; Mulligan, 1948; Head, 1953). According to Bloom, solitary benign mastocytomas in dogs consist of densely packed islands of well differentiated mast cells separated by strands of almost avascular stroma. More rarely the tumours are multiple and malignant, the neoplastic cells often containing one or more varieties of curious cytoplasmic inclusion. In dogs with multiple tumours malignant mast cells may also be found in liver, spleen, lung, marrow and in the regional lymph nodes, the liver and lymph nodes also often showing connective tissue hyperplasia. Bloom concludes (p. 674) 'It seems reasonable to assume that the neoplastic mast cells arose from proliferation of the preexisting tissue mast cells, and in this process lost their polymorphism and acquired a generally more oval or spherical form and a larger, relatively vesicular nucleus. The transformation was accomplished in the solitary tumors by amitotic activity, as evidenced by binucleation and occasionally constricted, elongated nuclei, and in the multiple tumors by mitoses and amitoses'. Malignant cells from mast-cell tumours in dogs and cattle have been successfully grown in tissue culture (Paff, Bloom and Reilly, 1947; Paff, Montagna and Bloom, 1947; MacDougall, 1954).

4. THE MAST CELL IN CARCINOGENESIS. Very early in the study of experimental carcinogenesis a striking mast-cell reaction was noted in the skin of 
mice undergoing local treatment with a carcinogen. This is particularly evident when the carcinogen is tar (Bierich, 1922; Dreifuss and Bloch, 1922; Peyron, 1923; Lipschütz, 1924; Ulesco-Stroganowa, 1927, de Viñals, 1931). The mastcell content of the painted area steadily increases during the induction period until, on occasion, the aggregates of mast cells become visible to the naked eye (Borrel et al, 1923; Schreuss, 1923; Fabris, 1927; Twort and Twort, 1930). That the mast-cell response is not merely part of a tar dermatosis is shown by the development of a similar reaction following the infrequent application of a pure carcinogenic hydrocarbon dissolved in benzene (Cramer and Simpson, 1944) or even in acetone (Orr, 1938). In seeking to evaluate the significance of the mast-cell reaction in carcinogenesis in the skin of mice, it is of interest that a mast-cell response has also been observed in the skin of rats subjected to the action of arsenic or X-1ays (Bierich, 1922) and in the skin of mouse or man following exposure to ultra-violet light (Meirowsky, 1908; Von Möllendorf, 1928). It seems that at least in certain spezies the mast-cell response is in some way related to the carcinogenic response, though the mechanism of the reaction is not yet understood.

To sum up. Later investigations on the mast cell in chronic inflammation and in pathological conditions characterized by fibrosis endorse Ehrlich's original belief that there is some functional association between the mast cell and the connective tissue, especially at the stage of fibrillogenesis: many of the observations on the occurrence of mast cells in and around established tumours can also be explained in this way. Other tumours rich in mast cells yet poor in fibrous tissue, and the curious local mastocytosis in the skin of mice during carcinogenesis are not yet understood. 


\section{CHAPTER V}

\section{THE MAST CELL AND HEPARIN}

I

1937, sixty years after Ehrlich's discovery, interest in the mast cell was suddenly stirred by the claim that the mast cell is the site of formation or storage of heparin, the natural anticoagulant of the circulating blood (Holmgren and Wilander, 1937). To those who had worked on the mast cell from a morphological standpoint (Michels, 1938) the new hypothesis was entirely unexpected; nevertheless, at first sight it seemed unassailable.

Scandinavian workers had for long been interested in a powerful anticoagulant, first isolated from dog liver and hence called 'heparin'. When it was first discovered, heparin was thought to be a phosphatide (McLean, 1916), but as a result of the tenacious researches of Jorpes (1946) and his colleagues, it was eventually shown that heparin is a polymer of disaccharide units (glucuronic acid and glucosamine) strongly esterified with sulphate (Jorpes, 1936). As Jorpes (1946) points out, it was the high sulphur content of the ash which supplied the analytical clue not only to the unusual nature of heparin but also to its remarkable inhibitory effect on the clotting process. However, it was already clear that the name 'heparin' is not entirely appropriate. Charles and Scott (1933,p.434) observe that, even in the dog, "the liver is not necessarily the seat of production for heparin, nor does it contain the only reserve of heparin in the body'. Whereas the liver of the dog is exceptionally rich in heparin, the liver in certain other species contains only the merest traces.

Two fresh findings combined to solve the mystery of the cytological location of heparin. Lison (1935), in Belgium, had discovered that the metachromatic staining reaction has histochemical significance, being positive with high molecular poly-sulphuric acid esters of the type $\mathrm{R}-\left[\mathrm{OSO}_{3} \mathrm{H}\right]_{n}$. Meanwhile, Jorpes (1936) had observed that the strongly acidic heparin in solution is precipitated by, and stains metachromatically with, the basic dye, toluidine blue. The next step was to search the tissues for a metachromatic component corresponding to sites rich in heparin.

Holmgren and Wilander (1937) then quickly rediscovered the metachromatic granules in the mast cells: cartilage, the only other common tissue component which stains metachromatically is almost devoid of anticoagulant activity (Jorpes, 1937). Holmgren and Wilander found mast cells to be so numerous in the capsule of ox liver that they describe it as a "pure culture of mast cells' and this tissue gave the highest yield of heparin: little heparin was found in the underlying parenchyma of ox liver which contains few mast cells. In contrast, mast cells are numerous in the liver parenchyma of the dog, the 
original source of heparin. Jorpes, Holmgren and Wilander (1937) extended their investigations to various human tissues, again finding a satisfactory correlation between mast-cell content and heparin value, and their findings have been thoroughly endorsed by later work (Ehrich et al, 1949). The mast cell-heparin hypothesis was confirmed some ten years later when a small mastcell tumour from the skin of a dog was found to contain fifty times more heparin than the animal's whole liver, the organ from which 'heparin' received its name (Oliver et al, 1947). Even the metachromatic granules of the blood mast cells are believed to contain heparin (Behrens and Taubert, 1952; Martin and Roka, 1953). As Jorpes (1946, p. 60) remarks, 'There is no doubt whatsoever about the nature of the granular substance of the mast cells. It is heparin.'

According to Quensel (1933) mast cells are especially common around thin-walled blood vessels and capillaries. Thus the new hypothesis seemed to offer an attractive explanation for the well-known perivascular distribution of the mast cells: mast cells are perivascular because they produce an anticoagulant which they pour into the circulating blood. Even to those with little taste for teleology it seemed that Ehrlich's 'riddle' had been solved.

The establishment of the mast cell-heparin hypothesis ended the second phase of interest in the mast cells. The first, as we have seen, was their discovery by Ehrlich and the evidence of later workers which appeared to relate the mast cells to the connective tissues. The second phase gave the mast cell its first physiological function; this seemed clearly to relate the mast cell to the blood. It is the purpose of the next section of this book to describe the work of my colleagues and myself in Scotland who have shown that the mast cell is not only rich in heparin, it is equally rich in histamine. This has again directed our thoughts towards a possible function of the mast cells in the tissues. Inevitably it has also raised doubts concerning the functional significance of the metachromatic substance of the mast-cell granules. 

PART II

EXPERIMENTAL 



\section{INTRODUCTION}

\section{The mast cell and carcinogenesis}

$\mathrm{M}$

Y own introduction to the mast cell occurred during student days, fortunately, perhaps, before the relationship of the mast cell to heparin had been discovered. One of my teachers in Edinburgh, the late Mr. J. J. M. Shaw, remarked that, in the course of some experiments on tar cancer in mice, he had confirmed an earlier observation of an increase in the mast-cell content of the painted skin (cf. Woglom, 1926). On being asked what was the function of these numerous cells with blue or purple granules, Mr. Shaw replied that he did not know. This confession of ignorance on the part of a favourite teacher was in itself so stimulating that I never forgot the mast cells: in particular, the thought remained that in some way the mast cell might provide a clue to the mechanism of carcinogenesis.

A few years later the first pure carcinogenic hydrocarbon, 1, 2, 5, 6dibenzanthracene, was identified and synthesized. This and other carcinogenic hydrocarbons dissolved in a non-irritant solvent, acetone, were used to paint the skin of a group of mice and were found to elicit a mast-cell reaction in the dermis similar to that which followed application of crude coal tar dissolved in benzene. When commercial heparin became available an attempt was made to influence the course of carcinogenesis by injecting heparin under the painted skin. Unfortunately, no clear cut results emerged from these latter experiments, nor from a more extensive investigation on the effects of injecting or feeding tumour-bearing mice with dyes which combine with heparin in vitro (Riley, 1948). Despite the disappointments, these early experiments at least confirmed my interest in the mast cells and raised the suspicion that these cells probably had functions other than the elaboration of an active anticoagulant for the blood.

Shortly after the war I came across the interesting monograph by Sylvén (1941) who stated that the mast cells release a metachromatically-staining 'free chromotrope substance' (F.C.S.) into the connective tissues during wound repair: and since Fell and Danielli (1943) had found a comparable increase of the enzyme alkaline phosphatase during fibroplasia, Dr. J. M. Drennan and I (1949) examined the distribution of mast cells, F.C.S. and alkaline phosphatase in a wide variety of animal tissues in the hope of finding a functional relationship. Again there was disappointment, but we did notice that in certain species the mast cells appeared to be migrating and maturing in a direction away from their origin around small blood vessels. This led my own thinking back to 
Ehrlich's original conception, that the mast cell is concerned with events in the tissues rather than in the circulating blood: in particular it seemed that the mast cell might be involved in the problem of tissue histamine.

\section{The mast cell and histamine}

As long ago as 1880 , Schmidt-Mülheim had shown that the dog reacts to an intravenous injection of peptone by a severe shock accompanied by a remarkable incoagulability of the blood. Almost a quarter of a century later Portier and Richet (1902) described a similar syndrome in dogs receiving a second dose of a foreign protein to which they had become sensitized; this acquired hypersensitivity they named 'anaphylaxis'. The so-called 'anaphylactic poison' causing the shock was shown in 1932 by Gebauer-Fuellnegg and others to be due to histamine, but it was not till 1938 that Wilander explained the incoagulability by demonstrating also a gross increase of the heparin in the circulating blood. More recently Rocha e Silva and his colleagues (1947) obtained large yields of both substances from the isolated dog's liver perfused with peptone or the specific antigen, and their findings have been confirmed (Jaques et al, 1954). In retrospect it is curious that no one seems to have thought that the histamine might also come from the mast cells, of which there are many in the liver of the dog (Nagayo, 1928, and cf. also Fig. 1). The speculation of the time was that since heparin is an acid and histamine a base, the heparin in shock states is released either to neutralize the histamine causing the shock or to oppose any increased clotting tendency of the blood. Testing this hypothesis, I found that an intravenous injection of histamine into the normal dog had no obvious effect on its clotting time, that peptone shock could be readily elicited in the fully heparinized $\mathrm{dog}$, and that an intravenous injection of a mixture of heparin and histamine was followed by the clinical signs of both-incoagulability of the blood and a fall in blood pressure. There was, in fact, no apparent antagonism between the two substances in the circulating blood, and no reason therefore for postulating that they must be derived from different sources in the tissues. The question thus became: could they arise together-even from the same cell?

This may now seem a somewhat obvious question to ask. However, at that time there was a distinct mental barrier against regarding heparin as anything but a natural anticoagulant. The existence of such a physiological anticoagulant had for long been predicted; its discovery accorded well with current views on blood coagulation. What perhaps is not adequately appreciated, even today, is that the hypothesis of a slow release of heparin into the blood as a natural anticoagulant rests on the findings in this single species, the dog, in which the violent release of heparin in shock states was assumed to be an exaggeration of a normal process. Yet the dog is the only animal known 
in which this anticoagulant has been shown to find its way from tissues to blood in the course of peptone or anaphylactic shock, and in no other species is there a comparable prolongation of blood clotting during anaphylaxis. It is true, as the Scandinavians had shown, that heparin can be extracted chemically

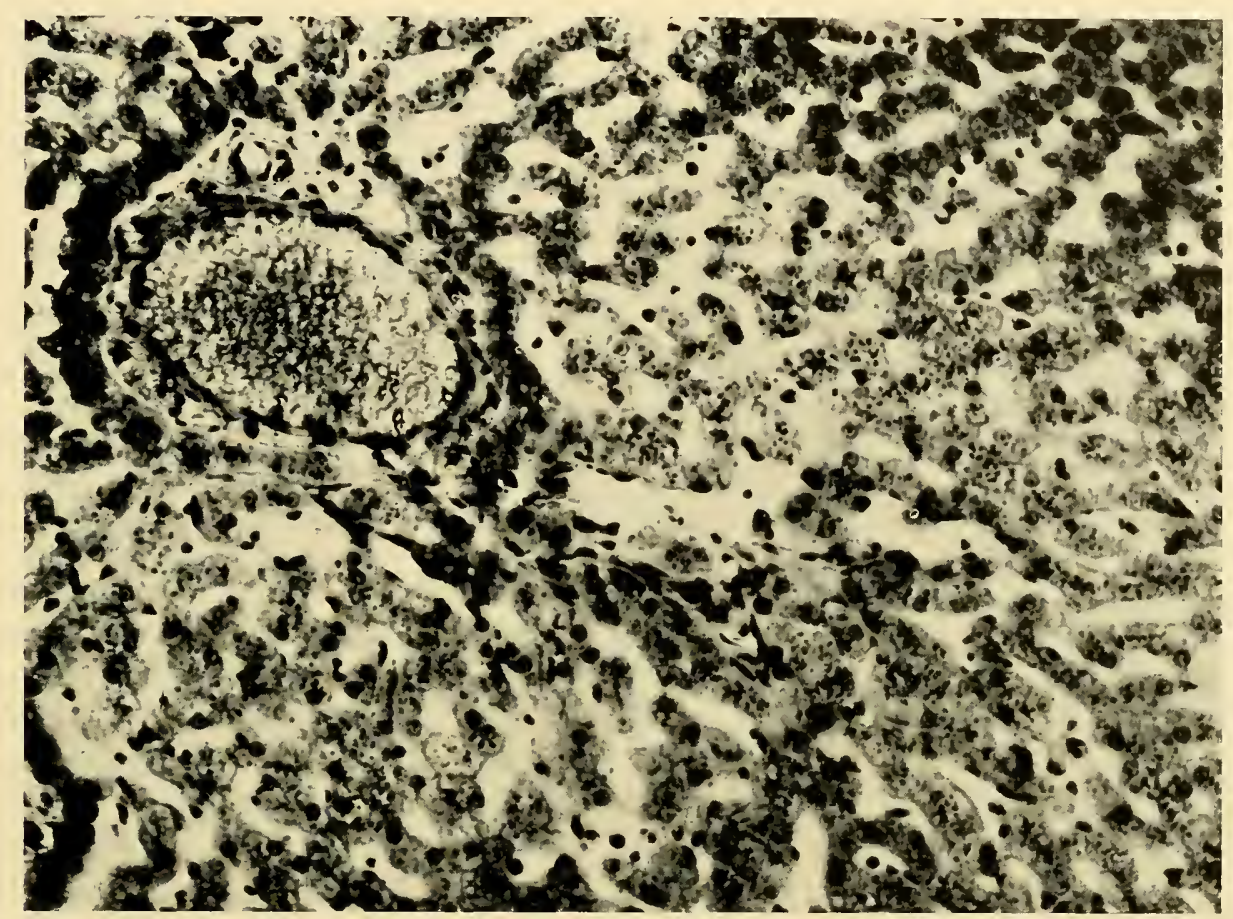

FIG. 1

Paraffin section dog liver, stained toluidine blue $(\times 192)$. The dark spots around the vein, in the portal tracts and scattered throughout the liver parenchyma are tissue mast cells. The dog is unique in having numerous mast cells in the substance of its liver. This finding has been turned to great advantage in solving the mystery of Ehrlich's mast cells.

from the tissues of many species and in proportion to the original mast-cell content, and that this extracted heparin, used in vivo or in vitro, proves to be a highly efficient anticoagulant. Even so, we are not compelled to believe either that a release of heparin is an essential feature of the anaphylactic syndrome in general or even that the normal function of the mast cell is to provide a constant slow release of anticoagulant to regulate blood clotting. The dog is the exception, not the rule, with respect to the function of its mast cells.

On the other hand, there was no lack of evidence at that time concerning the participation of histamine in anaphylactic shock in many species, though 
it is noteworthy that Sir Henry Dale himself warns us against the easy assumption that anaphylaxis and the release of histamine are synonymous. In his own words (Dale, 1954, p. 210), 'Anaphylaxis . . . is a phase of immunity, in which a precipitating antibody is located in such a relation to living cells of the fixed tissues or, in certain cases, of the circulating blood, that its union with the reinjected antigen subjects the cells to a sudden injury. To this injury, as to injury of any kind, these cells respond by the liberation of substances normally held in their protoplasm.' Thus the argument might be extended, that if the injured cell contains heparin it will release heparin, that if it contains histamine it will release histamine, and that if both are present in the same cell, both will be released during anaphylactic shock. We know that the release of histamine in anaphylaxis is a comparatively common event. As mentioned above, only the dog releases at the same time sufficient heparin to cause an obvious prolongation in the clotting time of its blood.

The question thus arises why does the dog alone show an incoagulability of the blood in shock states? A partial answer, at least, can be given on the factual observations that not only is the heparin from dog tissues a more efficient anticoagulant than are the heparins of other species (Jorpes, 1946; Bell and Jaques, 1956), but that even when the suprahepatic veins in the dog are closed by spasm of their muscular walls (as they are when there is histamine in circulation) there is still available the thoracic duct to lead the histamine and heparin from the 'shock organ', the liver, direct to the blood stream (Riley, 1955; White and Woodard, 1957): an enhancement of the lymph flow through the thoracic duct during shock states in the dog has long been known to occur (Petersen and Levinson, 1923; Drinker and Yoffey, 1941). In this way the heparin released in the liver of the dog during anaphylaxis avoids contact with the connective tissues and filtration through the lymph nodes. In other species the mast cells are not in a position to discharge their products directly into the blood. Therefore, it can be said that there is no strong reason to reject the idea that both histamine and heparin may come from a common source, the mast cell, in all species.

Turning next to conditions in man we find even more positive evidence of a relationship between the mast cell and histamine. Some years before Ehrlich first described the mast cells, Nettleship (1869) had observed that slight trauma to a focus of the skin disease, urticaria pigmentosa, leads to local swelling and a reddening of the surrounding skin. This is the reaction which Sir Thomas Lewis (1927) described as the 'triple response', a reaction later shown by Sir Henry Dale (1929) to be the visible evidence of the release of histamine in the skin. Very recently a case of widespread urticaria pigmentosa has been described in which the child suffered from recurrent histamine shocks; but there were no changes in the coagulability of the blood (Bloom et al, 1958a). Histo- 
logically, the beautiful description of Unna (1896) has been many times confirmed that the lesion of urticaria pigmentosa is an aggregation of mast cells.

\section{The discovery of the specific histamine-liberators}

It will be seen from the foregoing appraisal that there were two main problems in mind when the present work was begun: first, is the primary function of the mast cell to elaborate an anticoagulant for the circulating blood? Second, is the mast cell also a potent source of tissue histamine?

An approach to the first problem was made by examining the normal distribution of mast cells in as many tissues and species as possible, seeking evidence for or against the theory that the metachromatic substance in the mast granules (heparin?) is discharged direct into the blood. This work will be described first in the account which follows. Then in 1949 a paper appeared in the Journal of Physiology which seemed to offer a new and more direct approach to the second question, the relationship of the mast cell to tissue histamine. This was the account by MacIntosh and Paton, working at the National Institute of Medical Research, of a series of organic bases whose pharmacological action appeared to be a specific release of histamine. These compounds induced a 'triple response' when injected locally into the skin of man; they produced a profound, though significantly delayed, fall of blood pressure when injected intravenously into a cat; and in the dog their effects resembled to a remarkable degree the syndrome of anaphylactic or peptone shock - a fall in blood pressure and a prolongation of the clotting time of the blood. The discovery of the histamine-liberators offered a means of expanding the present investigation. The general plan of the work is given below.

1. To continue to obtain further information on the normal morphology and distribution of the mast cells in various species with a view to deciding whether they are functionally related to the blood or to the tissues: in particular to examine the relationship of mast cells to blood vessels.

2. To study the mast cells in pathological states, especially where there is clinical evidence of a release of histamine. (As stated above, the release of histamine is of more general occurrence than the release of anticoagulant heparin.)

3. To search for at least one species of laboratory animal suitable for experimental studies involving an artificial alteration in the content of its tissue mast cells, or tissue histamine, and to compare such changes: in particular, to observe the effect on the mast cells of the newly discovered histamineliberators.

4. To determine, by direct assay, whether there exists a positive correlation between the mast-cell content of a tissue and its histamine value. 
5. To trace the fate of the metachromatic 'heparin' which is released from the mast cells in species other than the dog.

6. To use such data as might be obtained in a further attempt to explain the role of the mast cell in chemical carcinogenesis in the skin of mice. 


\section{DETAILED DISTRIBUTION OF MAST CELLS IN CATTLE AND IN THE RAT}

\section{MAST CELLS IN CATTLE}

\section{T1}

HE classical mast cell-heparin hypothesis was based on the study of mast cells in ox liver capsule (Holmgren and Wilander, 1937). It seemed advisable, therefore, to make a comprehensive survey of the tissue mast cells in cattle.

All material was collected fresh at the slaughter house and was fixed at once. Tissue blocks were placed in formol-corrosive or in a freshly prepared 4 per cent solution of basic lead acetate clarified by the addition of a few drops of glacial acetic acid. Tissue spreads were fixed in 80 per cent alcohol. No advantage was seen to follow the use of alcoholic stains on this material providing the initial fixation had been adequate: accordingly, $0 \cdot 1$ per cent aqueous toluidine blue was used throughout. On the other hand, it was found that contact with water prior to fixation led to a rapid dissolution of the mast cells (Riley, 1954). The significance of this will be discussed later.

The following tissues were examined. Sections of brain, thyroid, lung, thymus, aorta and superior vena cava, liver, kidney, adrenals, bladder, spleen, large and small intestine, lymph node, skin, muscle and tendon, synovia and pericapsular tissues of the ankle joint. Tissue spreads of dura mater, thyroid capsule, pleura (visceral and parietal), pericardium (visceral and parietal), liver capsule, kidney capsule, peritoneum, subcutaneous connective tissue and tendon sheath. Representative illustrations are shown in Figures 2-10.

RESults. The outstanding finding from this survey of mast cells in cattle is the extraordinarily high mast-cell content of the capsules and serous membranes of the various organs. No conception of the mast-cell content of such membranes is obtained from a study limited to paraffin sections cut vertical to the surface of the organ in the conventional manner. Nor are the mast cells invariably, or even usually, related to the blood vessels in these capsules. This is particularly evident when tissue spreads of ox liver capsule and ox visceral pleura are examined (Figs. 6 and 9).

Further confirmation of this lack of relationship of mast cells to blood vessels in serous membranes was obtained by injecting the vessels. Lobes of lung and liver from freshly killed animals were washed out with warm Tyrode's fluid and injected (either by vein or artery) with a 10 per cent $(\mathrm{v} / \mathrm{v})$ solution of India ink in saline before stripping the 'capsule' and preparing the tissue 
spreads. Ox liver capsule proved to be almost avascular, whereas small vessels were comparatively common on the surface of the lung. In neither case, however, were the mast cells disposed in relation to the vessels: the cells immediately under the mesothelial surface of both organs seemed to have an entirely random distribution. Paraffin sections of lung indicate that mast cells often surround the subpleural vessels: even here, the cells lie mainly in the perivascular adventitia of the small vessels with muscle coats (Fig. 10).

In some preparations mast cells appeared to be relatively common around the subpleural lymphatics (Fig. 10). Further specimens of lung and liver were therefore injected locally with a 1 per cent solution of the colloidal acid dye, Evan's blue (T. 1824), in saline in the hope of demonstrating the lymphatics. The injection was made immediately under the capsule and the area was then massaged to spread the dye and force it into the lymphatic spaces. Examination of these spreads indicated that in general there is no more evidence of a relationship of mast cells to lymphatics in ox liver capsule and ox pleura than there is of their relationship to the blood vessels. The comparatively few additional mast cells in the parenchyma of lung and liver which are seen in paraffin sections are situated chiefly in the loose connective tissue surrounding the bronchi and the portal tracts.

A rather curious observation was made in the capsules injected supravitally with Evan's blue. In addition to filling the lymphatics the dye often stained faintly the mast granules themselves. Such staining does not occur in fixed preparations. This suggests that the mast granule in the living state contains an albumin component for which Evan's blue has a strong affinity, as it has for the albumins of the plasma proteins: this may perhaps be the 'heparin complement' described by Snellman, Sylvén and Julen (1951). The unexpectedness of the observation lies in the fact that the mast granules are among the most intensely basophilic structures in the body, the only other known method of staining them with an acid dye being that of Bujard (1930) in which mast cells in paraffin sections treated with bromine can now be stained with acid fuchsin.

Mast cells are somewhat more obviously related to small blood vessels in the dura mater, peritoneum, pericardium and tendon sheaths, though, as in lung, they are more common around small vessels with a well-defined adventitial coat than around the capillaries (Figs. 2, 3 and 4).

If the search for mast cells in cattle had stopped at this point it might well have appeared that the function of the mast cell is related to some property common to serous membranes, perhaps to the formation of the mucinous material which lubricates their surfaces. Such an hypothesis might also account for the high mast-cell content of the synovial joints which develop from clefts in the primitive mesenchyme. However, it appears less likely when 


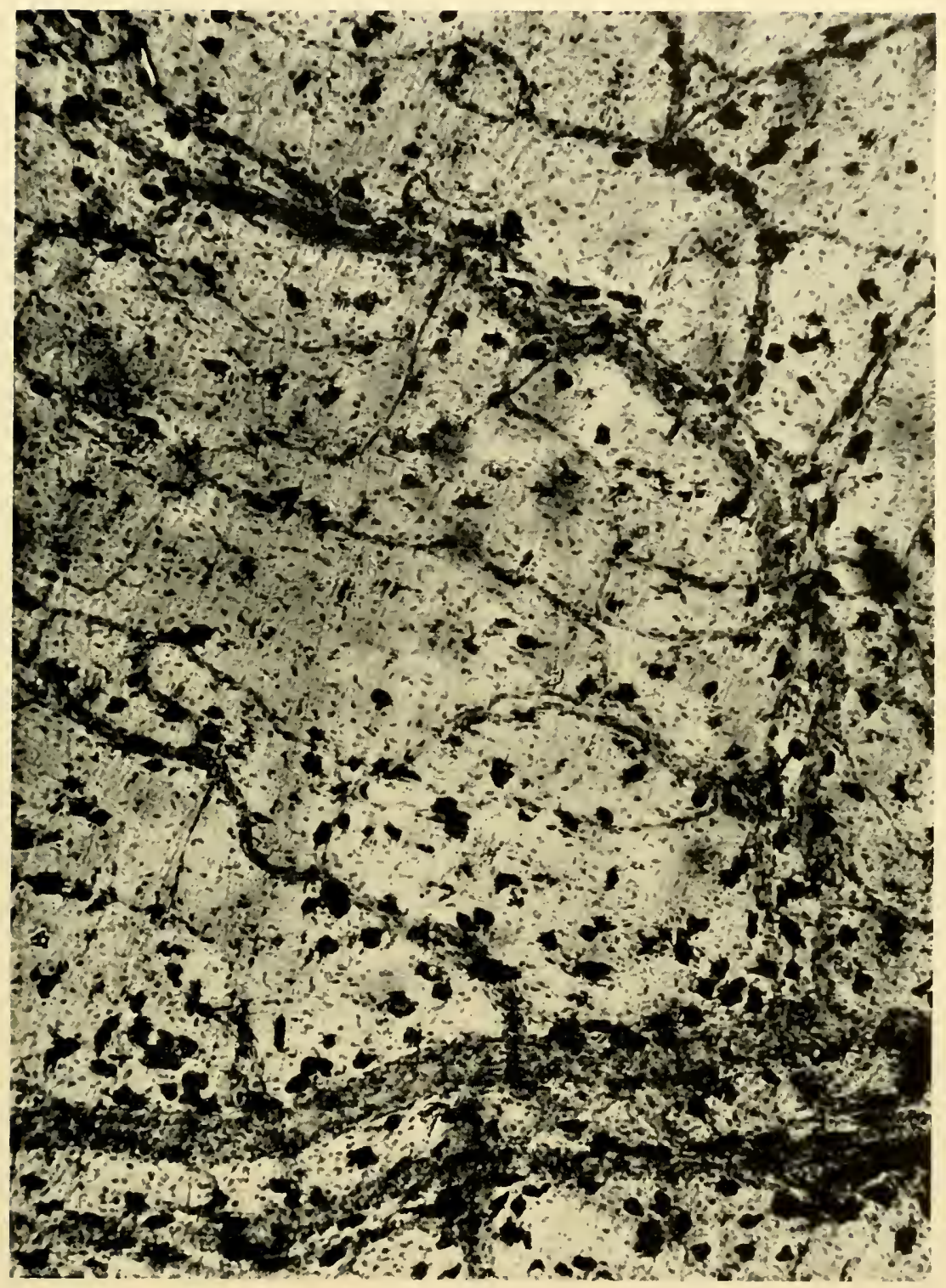

FIG. 2

Tissue spread, ox peritoneum; fixed alcohol, stained toluidine blue $(\times 175)$. Mast cells (dark spots) around arteriole and venule and scattered over the serosa. 


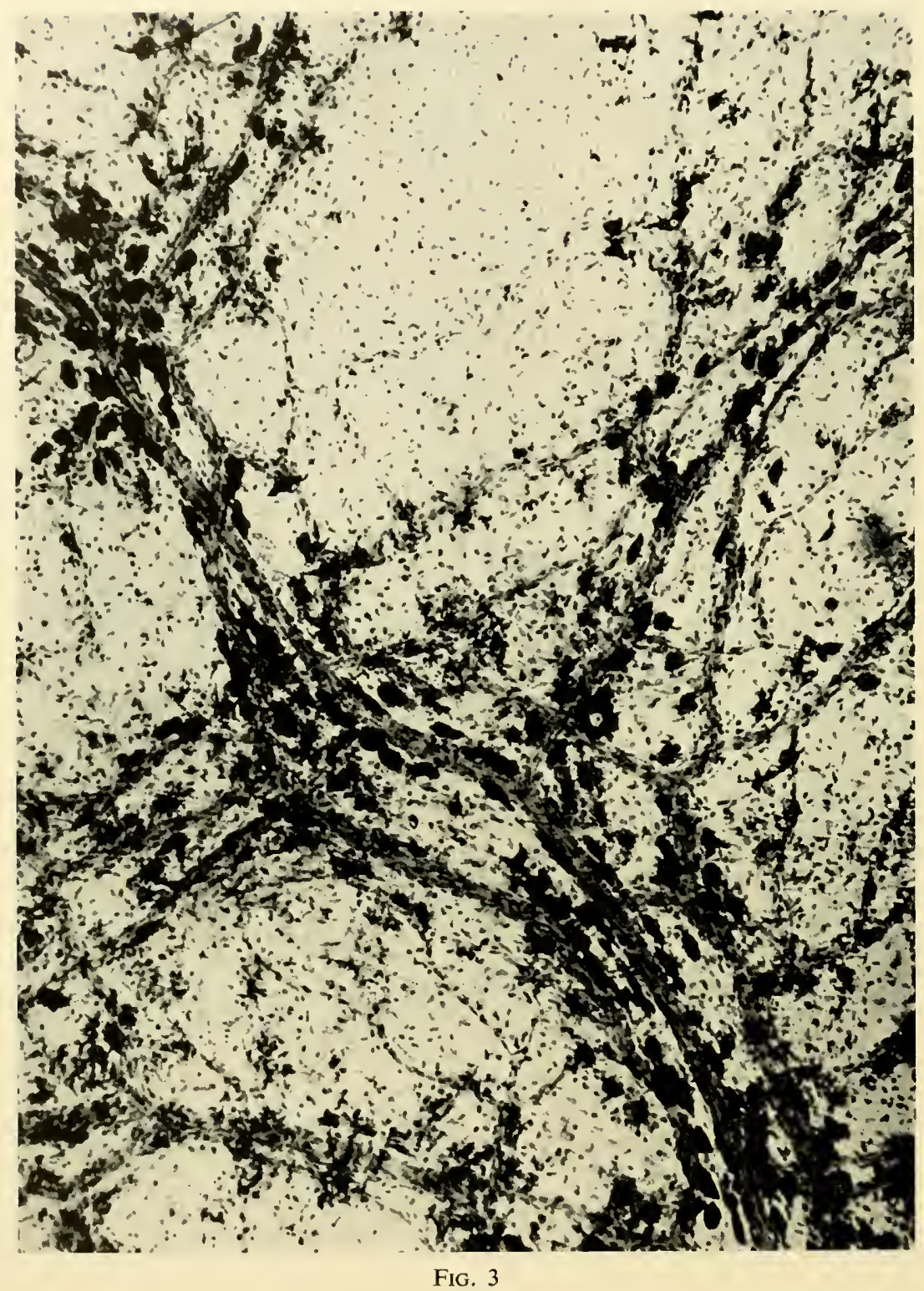

Tissue spread ox visceral pericardium (as in Fig. 2). The loose perivascular distribution of the mast cells is well seen $(\times 175)$. 
the capsules of kidney, thyroid, thymus and adrenal are examined, and it hardly explains the association of mast cells with the connective tissue generally.

Kidney capsule forms an interesting comparison with the capsules described above, in that the true capsule of the kidney is separated from the overlying peritoneum by a thick pad of loose perinephric fat and connective tissue. Nevertheless, a tissue spread of kidney capsule shows it to contain a high content

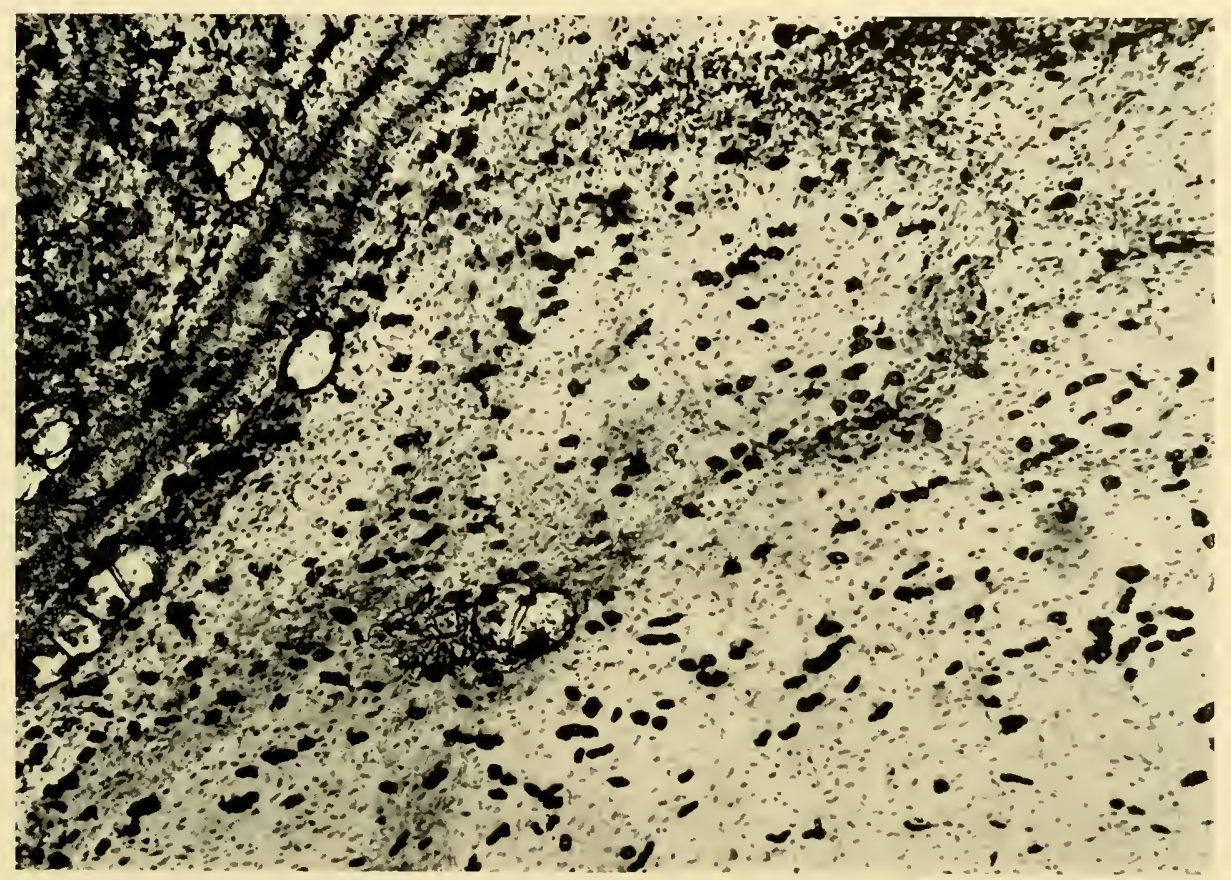

FIG. 4

Tissue spread ox tendon sheath. Many mast cells, singly or in pairs, are scattered over the serous surface $(\times 140)$.

of mast cells (Fig. 8). In contrast, mast cells are entirely lacking in the kidney parenchyma, though they are again seen in the subepithelial connective tissue of the kidney pelvis and remain plentiful in this type of tissue throughout the urogenital tract. Mast cells also occur in the capsules of organs which are unrelated to the serous membranes: they are common in the loose connective tissue which surrounds the thyroid and the adrenals and in the capsule and trabeculae of the thymus. Indeed, mast cells are demonstrable in all the loose fibrillary connective tissue in cattle: this includes the dermis and subcutis, the loose intermuscular connective tissue of both voluntary and involuntary muscles and the subsynovial and pericapsular connective tissue of joints. Tissue of similar appearance can be traced in continuity from the pericardium 


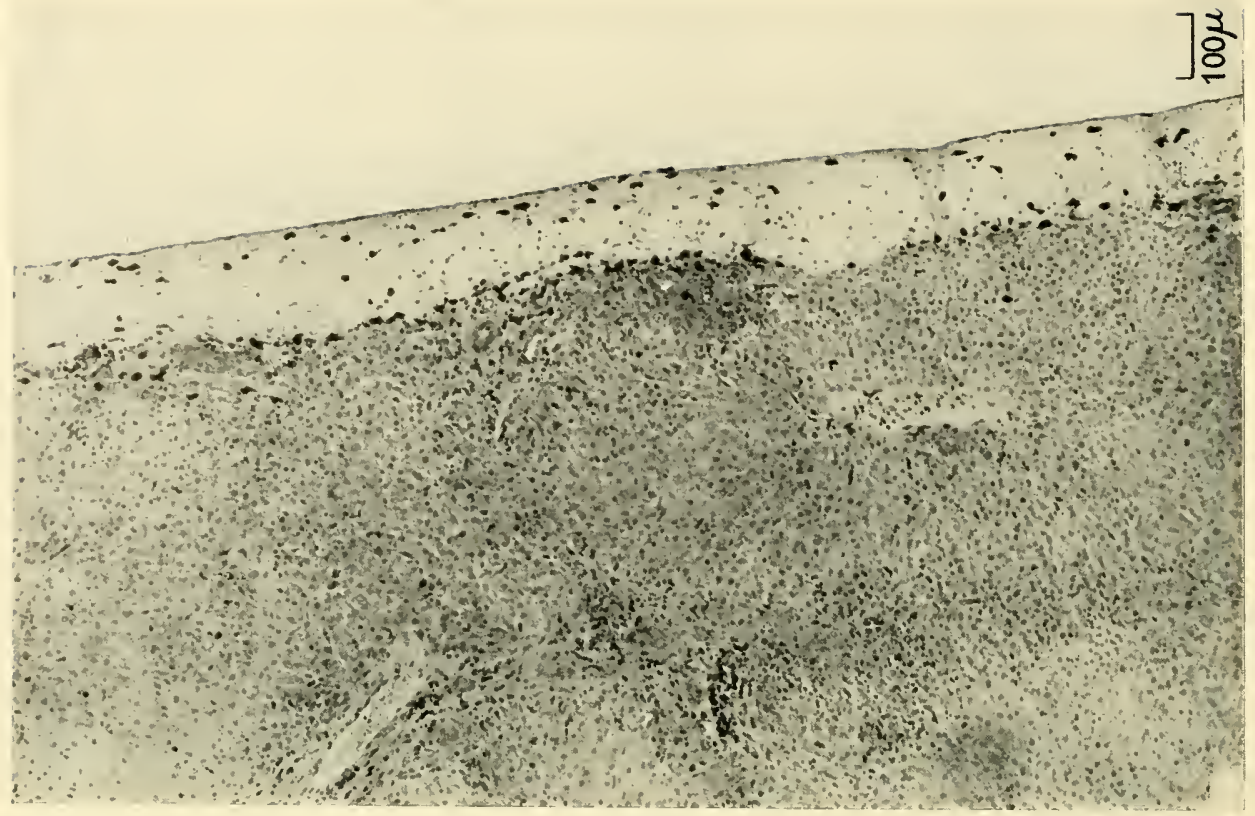

FIG. 5

Paraffin section ox liver. This confirms that virtually all the mast cells in the liver of this species are in the capsule. Contrast fig. 1 for conditions in the dog. Toluidine blue $(\times 80)$. (Riley and West (1953), J. Ph!siol. 120, 528.)

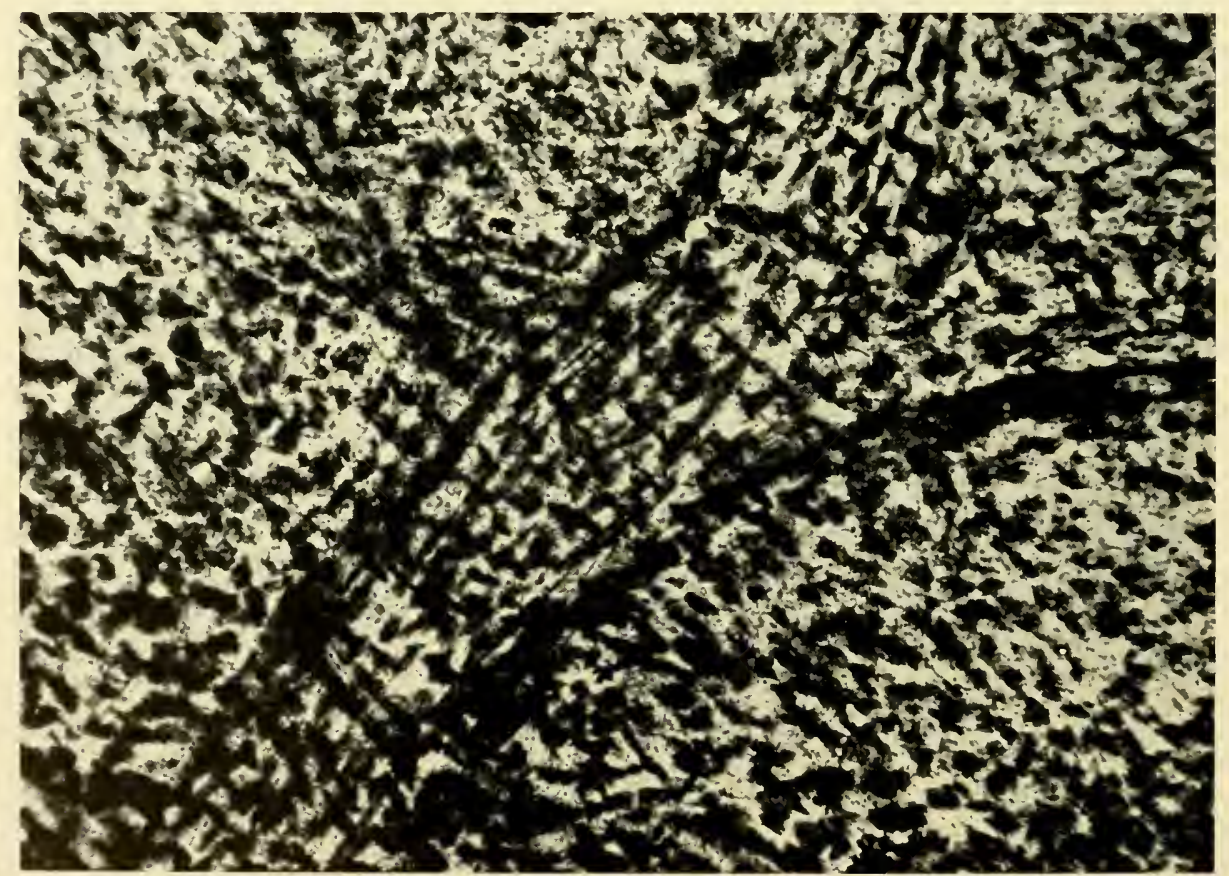

FiG. 6

Cleaned tissue spread of ox liver capsule. There are so many mast cells and scattered granules that it is difficult to transmit light through the preparation $(\times 140)$. 
along the great vessels (especially the veins) down to the smallest arterioles and venules, around which it forms their adventitial sheath.

Such loose connective tissue is also common in the wall of the gut, filling the spaces between the deeper portions of the glands and forming the underlying submucosa. Enormous numbers of mast cells can be demonstrated in any section of the complex gastric organ of cattle. In the submucosa of the

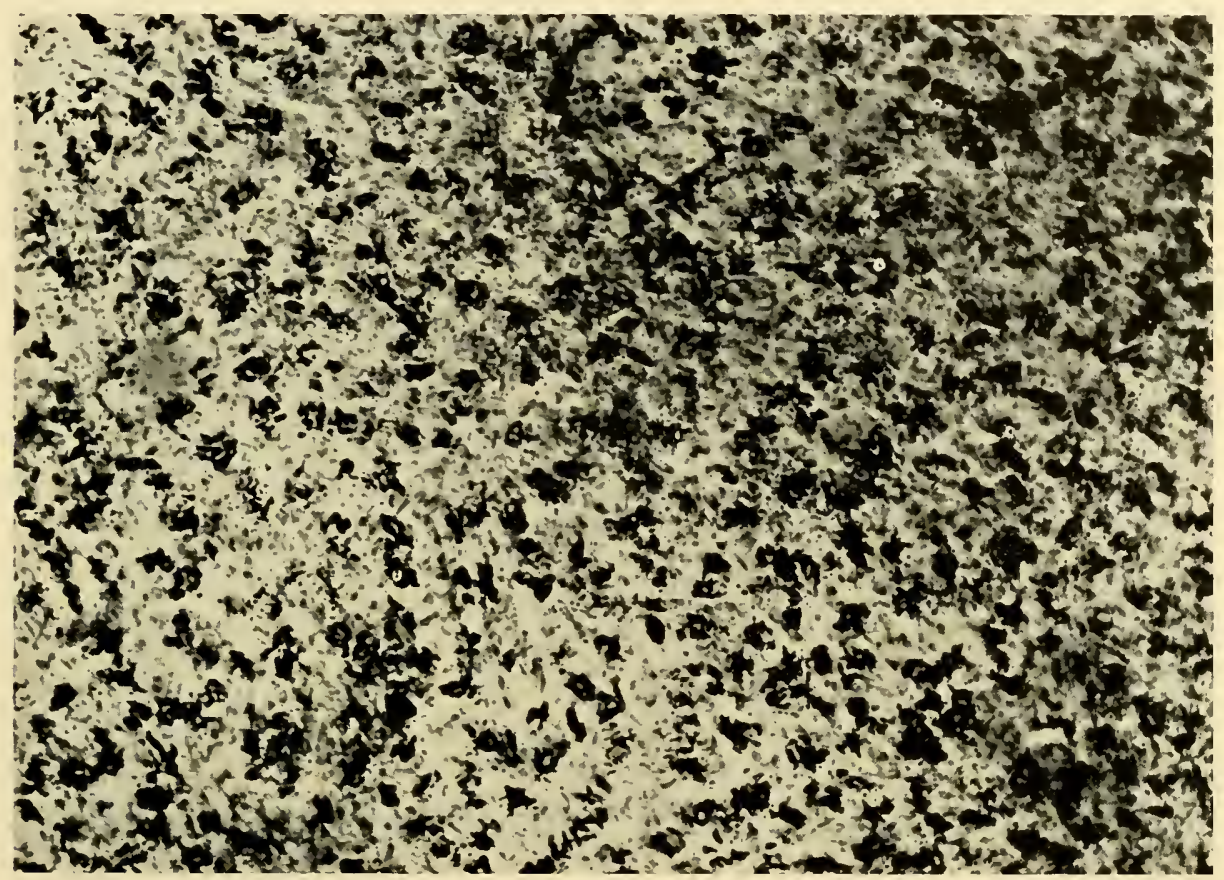

FIG. 7

Tissue spread, calf liver capsule. The mast cells are fewer and less well granulated than in the adult $(\times 168)$.

small intestine the cells are concentrated especially around non-encapsulated lymphoid nodules: where such a nodule is cut tangentially the appearances suggest a solid focus of mast cells. Their presence under the investing layer of peritoneum has been described above.

Mast cells are not common in lymph nodes proper and do not occur in cartilage (ear and trachea), in mature collagen (tendo achilles) or in mature elastic tissue (ligamentum nuchae). Nor are they seen within the central nervous system, though they are common in the dura mater and the connective tissue sheaths of peripheral nerves and occur also around the blood vessels of the choroid plexuses.

This survey of the tissue mast cells in cattle thus emphasizes more their 


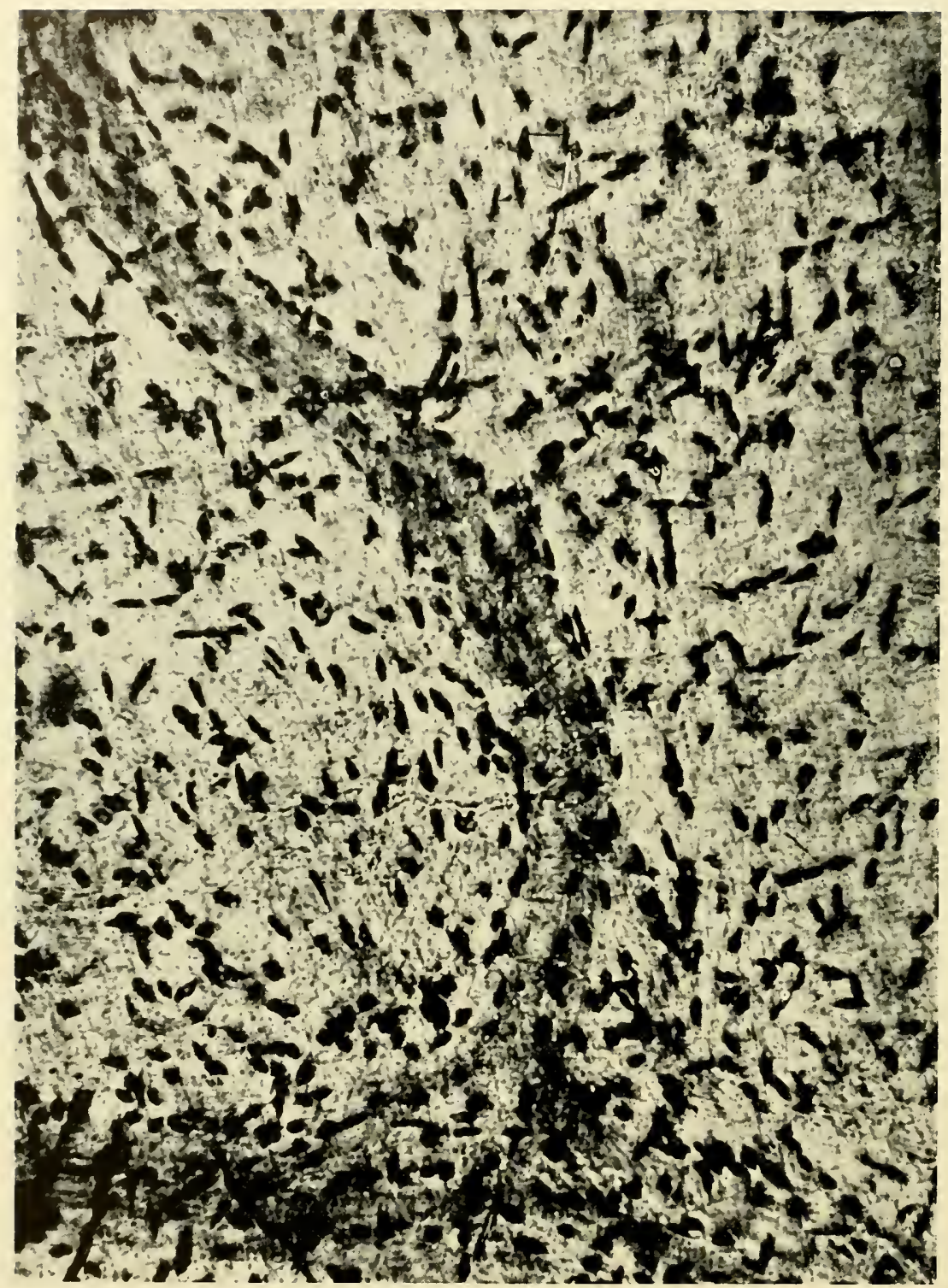

F1G, 8

Tissue spread ox kidney capsule. Despite the fact that this is not a true serous membrane it still carries a rich complement of mast cells in its connective tissue $(\times 175)$. 


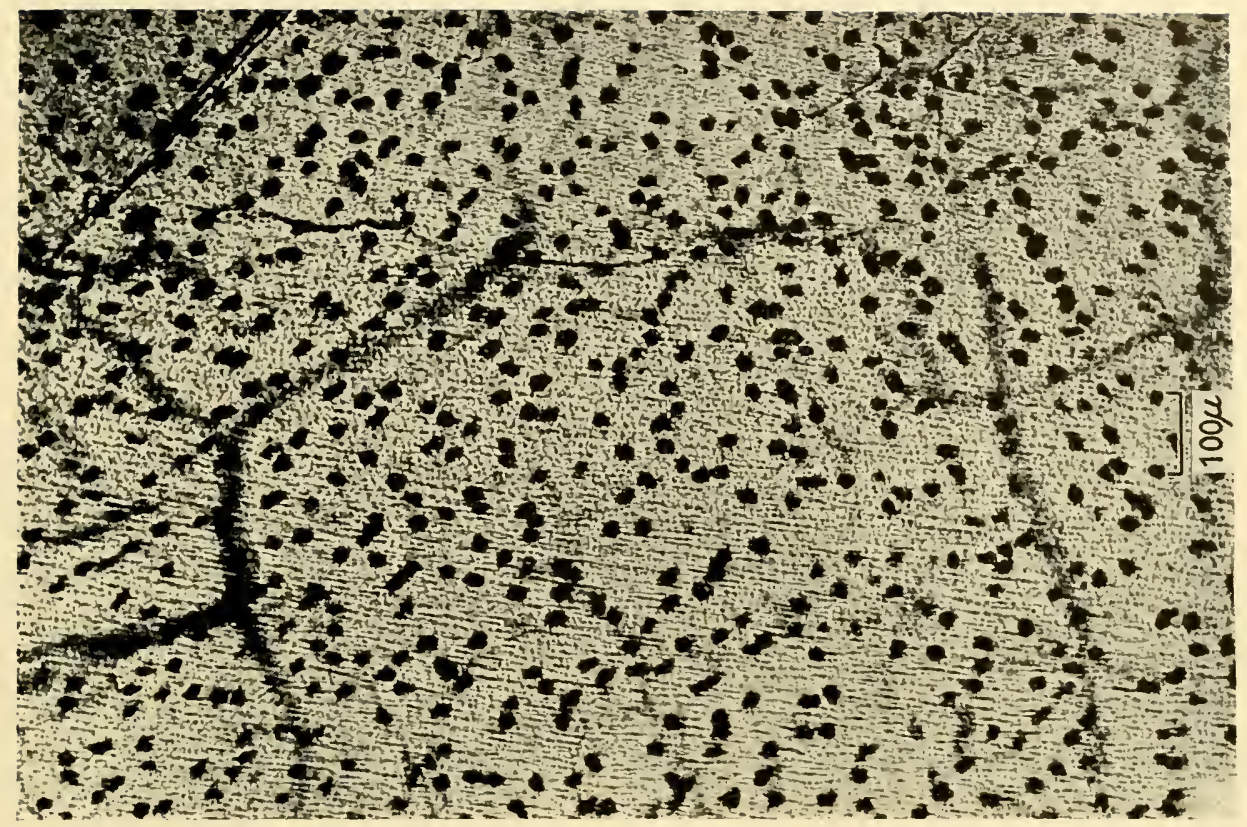

FIG. 9

Tissue spread, ox visceral pleura. The thin surface membrane contains numerous mast cells. (Riley and West (1953), J. Physiol. 120, 528.)

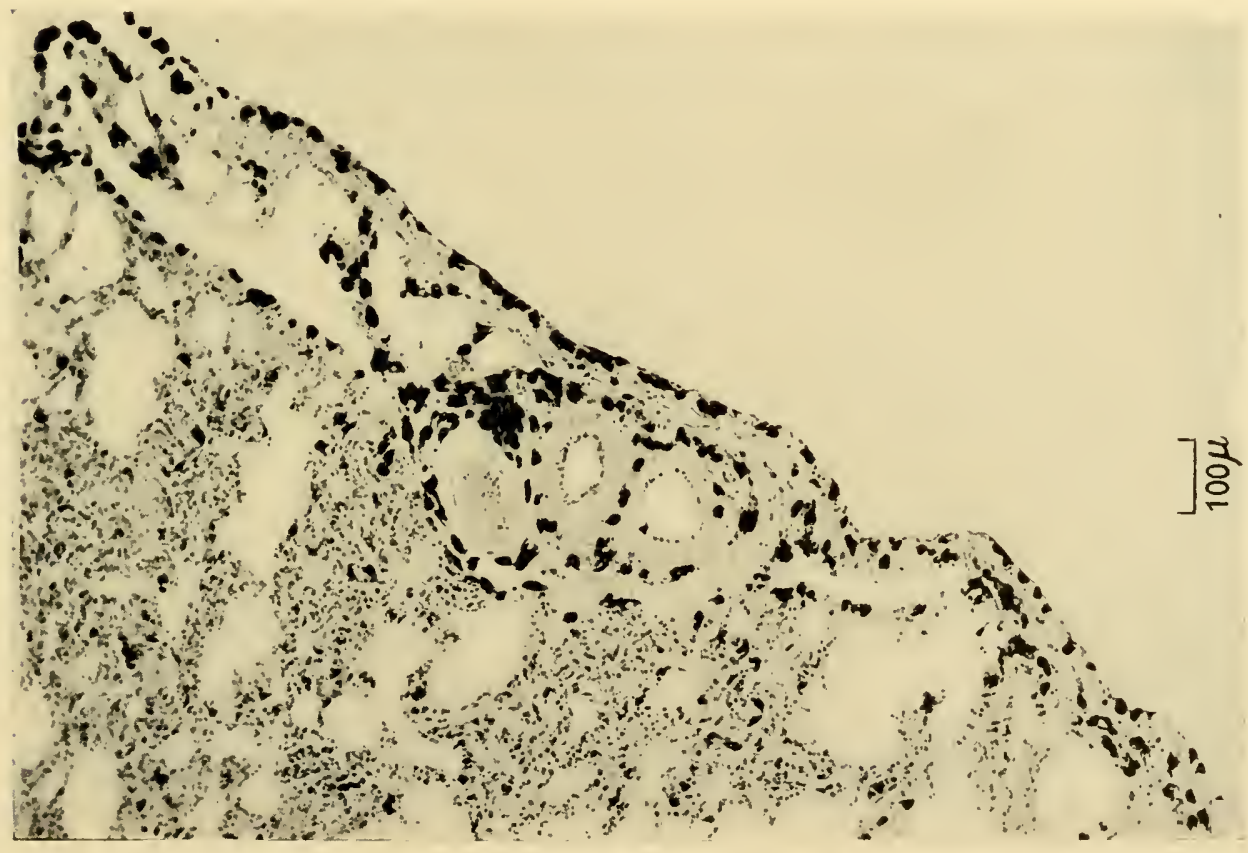

FIG. 10

Vertical paraffin section, ox lung. Nearly all the mast cells are situated in, or immediately beneath, the pleura; they are common in the adventitia of the small vessels with muscle coats and around the lymphatics. Only a few are seen in the lung parenchyma. (Riley and West (1953), J. Physiol. 
association with a special type of loose connective tissue of wide distribution than with any particular organ. Due weight must be accorded to this fact in any hypothesis which attempts to explain the function of the mast cell.

\title{
MAST CELLS IN THE RAT: THEIR RELATIONSHIP TO THE BLOOD VESSELS
}

\author{
(See Riley, 1953a)
}

Examination of mast cells in tissue spreads of subcutaneous connective tissue and peritoneum from cattle was often rendered difficult by the presence of fat, which continued to escape from intact fat loculi in the mounted preparations despite their having been previously immersed in xylol for as long as forty-eight hours. This was the more troublesome as one of the objects of the present study was to determine the precise relationship of the mast cells to the small blood vessels which are otherwise admirably displayed in preparations of this kind. Accordingly, a number of the common laboratory animals were examined with a view to finding one from which permanent tissue spreads could be made and upon which, if necessary, various experimental procedures could be carried out. Of the species examined (dog, cat, guinea pig, rabbit, hamster, mouse) the Wistar strain of albino rat appeared to be the most suitable. A preliminary survey of its tissue mast cells was therefore first undertaken, as in the previous survey of the tissue mast cells in cattle.

The following tissues were examined. Sections of brain, lung, thymus, oesophagus, stomach, duodenum, large and small intestine, spleen, pancreas, liver, kidney, uterus, skin and muscle. Tissue spreads of dura mater, subcutaneous connective tissue, dorsal skin and subcutis of ear, diaphragm, mesentery, omentum and the peritoneal fringes which are attached to uterine horns in female rats (Figs. 11-18).

RESUlTS. Again the most striking single finding arising from this survey of mast cells in the rat is the astonishing abundance of mast cells in the connective tissues and serous membranes in contrast to the paucity of mast cells in the parenchymatous organs. There are no mast cells in the brain substance or in the kidney, and very few in the liver, spleen and pancreas (Fig. 16) though they are found in the meningeal or peritoneal coverings of these organs.* Mast cells are rare even in the lung. The comparatively small numbers which are seen in the thymus are situated almost exclusively in the loose peri-thymic and inter-lobar connective tissue. A few occur also in similar connective tissue in the diaphragm and in the loose connective tissue lying between the

* $1 \mathrm{t}$ is interesting now to consult the original article by Waldeyer (1875) and observe his excellent illustration (Fig. 1, pl. IX) of the so-called 'plasma cells' near blood vessels in a tissue spread of rat dura mater. These are obviously tissue mast cells. 
bundles of voluntary muscles, especially in the tongue. However, they are rare immediately under the surface epithelium of the tongue, which lacks the usual layer of subepithelial connective tissue and cannot be lifted off the underlying muscle (Fig. 17). Where such connective tissue is present, mast cells are always to be found and their number is roughly proportional to the vascularity of the part. They are thus very common in the subcutis of the nose and paws and in the immediate vicinity of the nipples and ano-genital orifices. They are exceptionally common in the thin subcutis of the ears in which they often surround the hair follicles in characteristic circular patterns (Fig. 18, and compare also Fig. 56).

Mast cells are seen in the wall of the oesophagus mainly around the veins. A few occur in the deeper mucosa and the submucosa of the stomach, whence they may be traced in diminishing numbers down the rest of the alimentary tract.

In contrast to the general paucity of mast cells in paraffin sections of the various parenchymatous organs (Fig. 16), a striking picture is seen when tissue spreads stained with toluidine blue are examined. Here the predominant cell is the mast cell and the relationship of the mast cells to the blood vessels in such material can be accurately determined. The reader is referred to the original publication for technical details of the methods which were devised for injecting the blood vessels of the rat and for preparing and staining the tissue spreads (Riley, 1953a).

\section{Dorsal subcutaneous connective tissue}

Vessels. The dorsal subcutaneous tissue of the rat is characterized by the presence of parallel neurovascular bundles which run in segmental fashion round the flanks and ultimately contribute to the rich vascular network of the mammary glands (Figs. 11-13). These vessels themselves often throw off branches laterally into the transparent connective tissue separating them from adjacent neurovascular bundles, either as a tree-like arborescence (Fig. 13) or, more rarely, a closed vascular loop (Fig. 12). Not infrequently their branches anastomose with corresponding branches from the next main vessel. At their origin the smaller twigs have usually a double muscle coat and this, in turn, is surrounded by an adventitial sheath of connective tissue from which are derived such perivascular fat cells as may be present. As the calibre of the vessel diminishes, first the outer layer of muscle is lost, then the inner, and finally the adventitia until around the capillaries only an occasional adventitial cell remains.

MAST CELLS. The neurovascular bundles themselves are enveloped in a swarm of elongated ovoid mast cells lying in the adventitia close to and parallel with the walls of small vessels (arterioles and venules) with muscle coats. These 
cells stain uniformly in a blue, orthochromatic tint and so densely as to obscure the nucleus. For convenience these may be called type-I mast cells.

If we now follow the vessels distally it is seen that there is a gradual change in the type of perivascular mast cell. Where the muscular vessels are enveloped in fat the type-I cells remain close to the vessel between the muscle and the surrounding fat. However, where the muscular vessels traverse loose connective

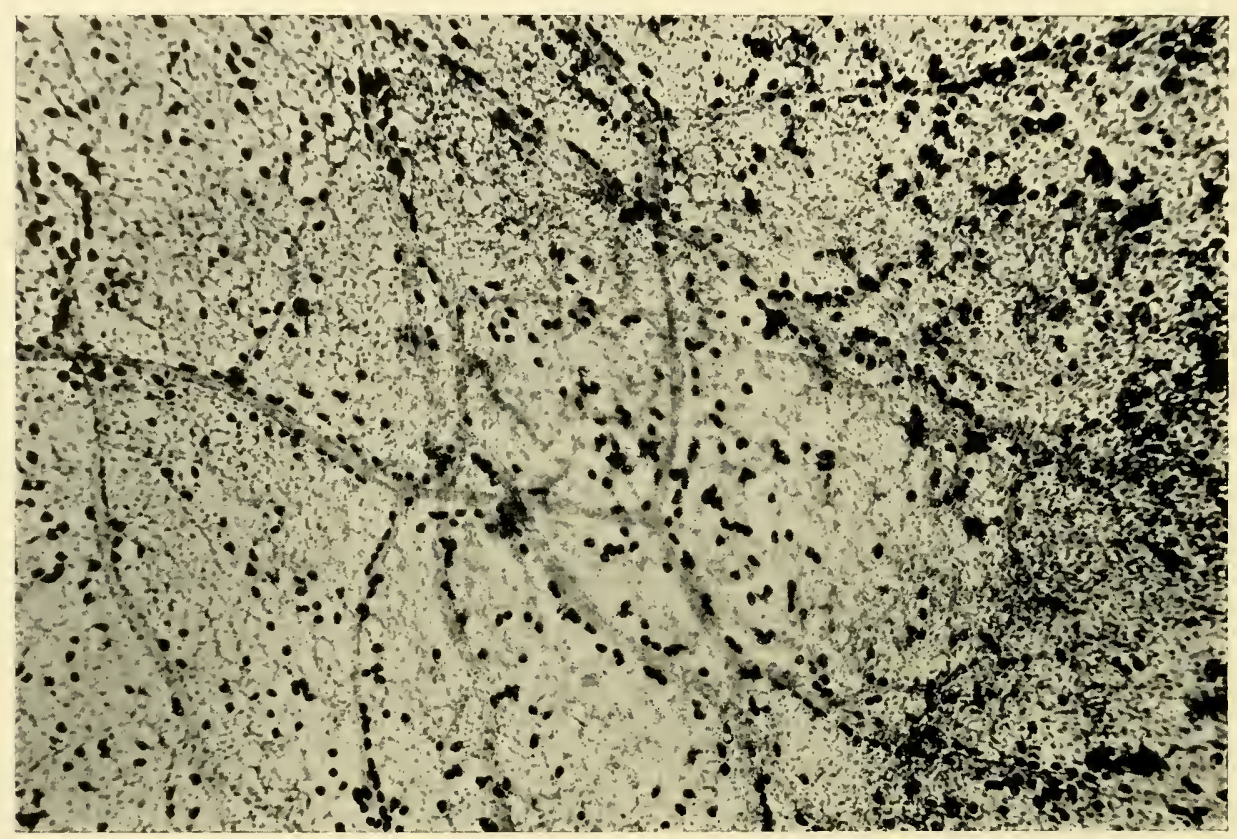

FIG. 11

Mast cells in connective tissue near mammary gland. Chains of type-I cells accompany the main vessels with muscle coats. Scattered type-II cells are associated mainly with capillaries, best seen to the right of the field $(\times 40)$. (Riley $(1953), J$. Path. Bact. 65, 461.)

tissue the type-I cells appear free to move away from the vessel wall and to become larger and irregular in shape. In these cells the homogeneous staining is gradually resolved into orthochromatic granules set in a clear cytoplasm and, as the granules become further dispersed, they stain purple to red (metachromasia). These cells have been designated type-II mast cells. In some of them the round nucleus is represented by a clear space from which the granules have been pushed aside. Around the capillaries type-II cells predominate, though an occasional small type-I cell remains close to the capillary itself. In addition, occasional dense clumps of 3-20 type-II cells are found isolated in the interspaces of the dorsal subcutaneous connective tissue remote from any demonstrable vessel. These cells frequently show a cross-scored appearance from 
MAST CELLS IN CATTLE AND RAT

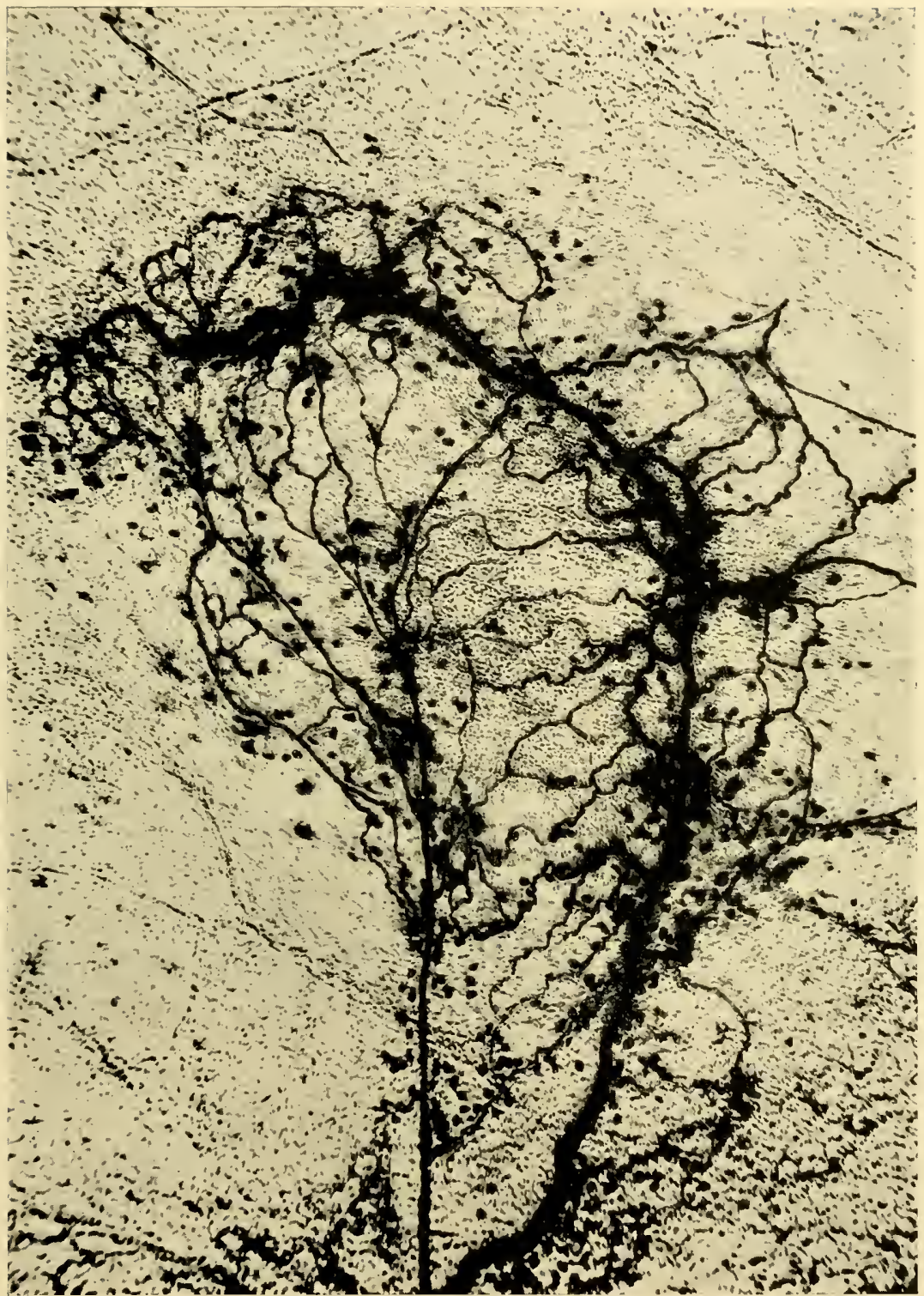

FIG. 12

Closed vascular loop in subcutaneous connective tissue from rat previously injected to show small vessels. The mast cells lie predominantly around the peripheral vessels with muscle coats and a well-marked adventitia $(\times 50)$. (Riley (1953), J. Path. Bact. 65, 461.) 
the imprint of connective tissue fibrils - clear lines across the cytoplasm which were regarded as 'granule canals' (Lehner, 1924) until their true nature was established by Webb (1931-32). These isolated clumps are characteristic of the dorsal connective tissue and are not seen elsewhere.

In the flanks near the mammary glands, portions of which were sometimes included in the spreads, the $Y$-shaped vessels with double muscle coats undergo repeated bifurcation to become capillaries. Here the difference in distribution of the two types of mast cells is very striking (Fig. 11). In the adventitia of the muscular vessels pure type-I mast cells are often arranged in unbroken

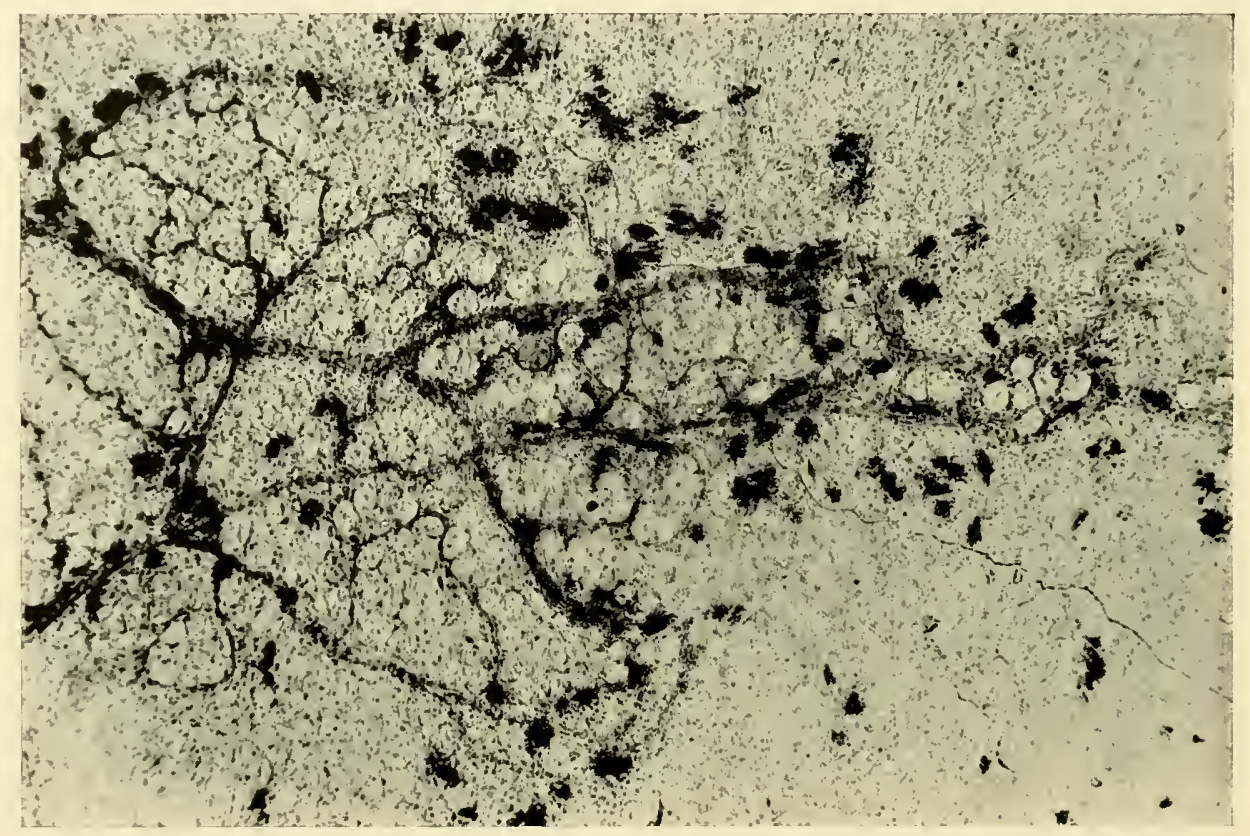

Fig. 13

Fringe of arborising vascular pattern in subcutaneous connective tissue. The associated mast cells are mainly type II and as they migrate away from the vessels they become smaller from loss of granule substance ( . 55). (Riley (1953), J. Path. Bact. 65, 461.)

chains; these gradually change into type-II cells and clumps as the capillaries appear.

\section{Mesentery}

VESSELS. The mesenteric vessels in the rat, as in man, form vascular arcades framing clear peritoneal windows. In the rat these arcades usually consist of more than one pair of muscular vessels enclosed in a common sheath of fat. At intervals, lateral twigs from the muscular vessels pierce the fat and ramify as a delicate lacework of capillaries over the peritoneal window. 


\section{MAST CELLS IN CATTLE AND RAT}

MAST CELLS. Type-I cells accompany the main vessels of the arcades and their lateral twigs, changing rather abruptly into type-II cells as the vessels break up into capillaries. These type-II cells are scattered, singly or in pairs. over the clear peritoneal window at various distances from the nearest capillary and many of them show the imprint of connective-tissue fibrils.

\section{Omentum}

Vessels. As in the mesentery, the main vessels with muscle coats are surrounded by a crenellated fatty sheath. However, in stained spreads the

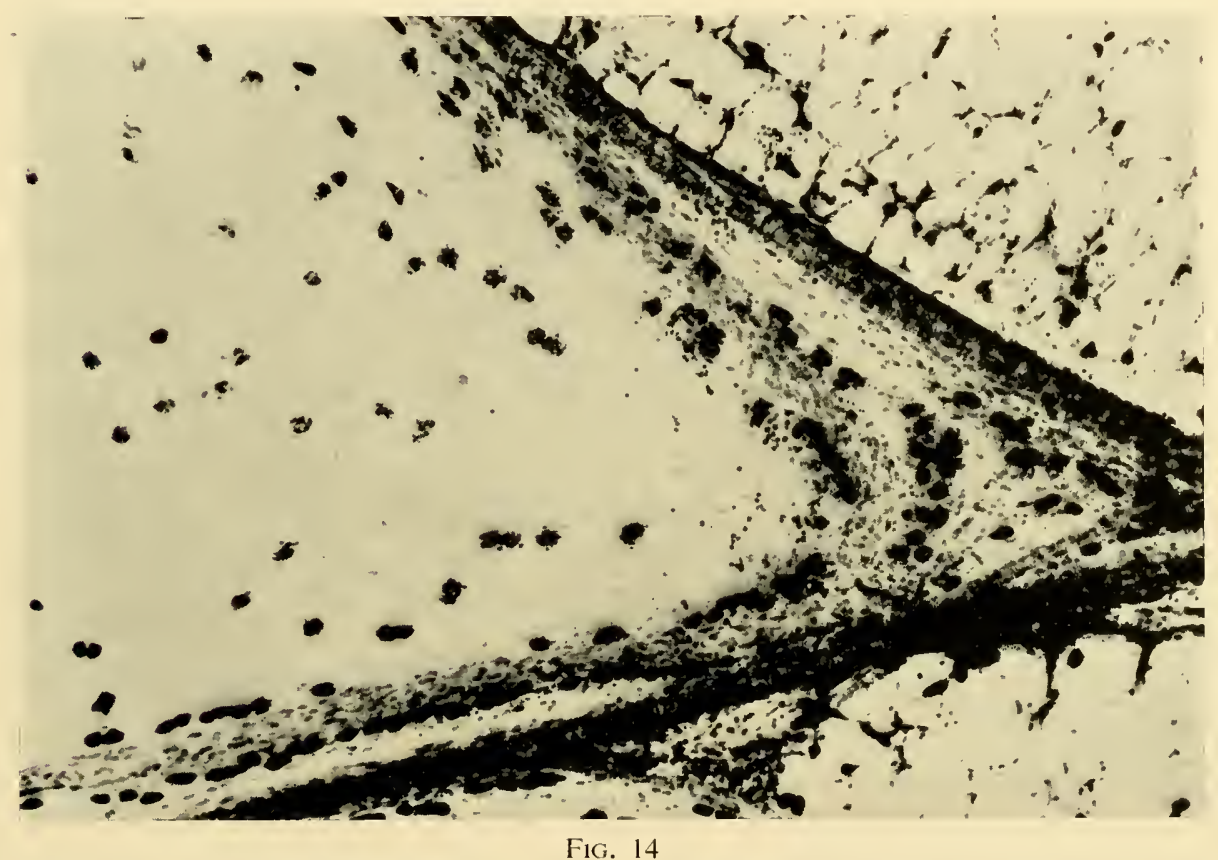

This shows the bifurcation of a small blood vessel in a peritoneal fringe from one of the uterine horns. The upper branch has along its outer wall a dense layer of mast cells seen as a solid black line; the layer of mast cells in the adventitia of the upper aspect of the lower branch seems to have become slightly dislocated from the vessel wall. Between the two branches the mast cells are fanning out into the loose connective tissues, maturing, and then undergoing degranulation $(\times 75)$. (Riley (1953), J. Path. Bact. 65, 461.)

omental sheath can be clearly differentiated from that of mesentery by the presence of darkly staining areas along its free margins and, to a less extent, in the intervening peritoneum. These areas are the milk spots or "tâches laiteuses' described by Webb (1931-32) in his study of peritoneal mast cells in the rat (Fig. 15). A muscular branch from the main arteriole pierces the fatty sheath to reach a milk spot and there breaks up into a leash of smaller vessels. Having supplied the milk spot, the vessels are gathered together into 
one or more venules which return parallel to the afferent arteriole or first link up with other milk spots before joining the main vein.

MAST CELLS. Type-I mast cells lie close to the muscular walls of the main arterioles and venules and their branches. In the milk spots a new arrangement of mast cells is seen. The milk spot itself consists of a knot of small mesenchymal cells and a few fat globules. Many of the small cells have a narrow rim of

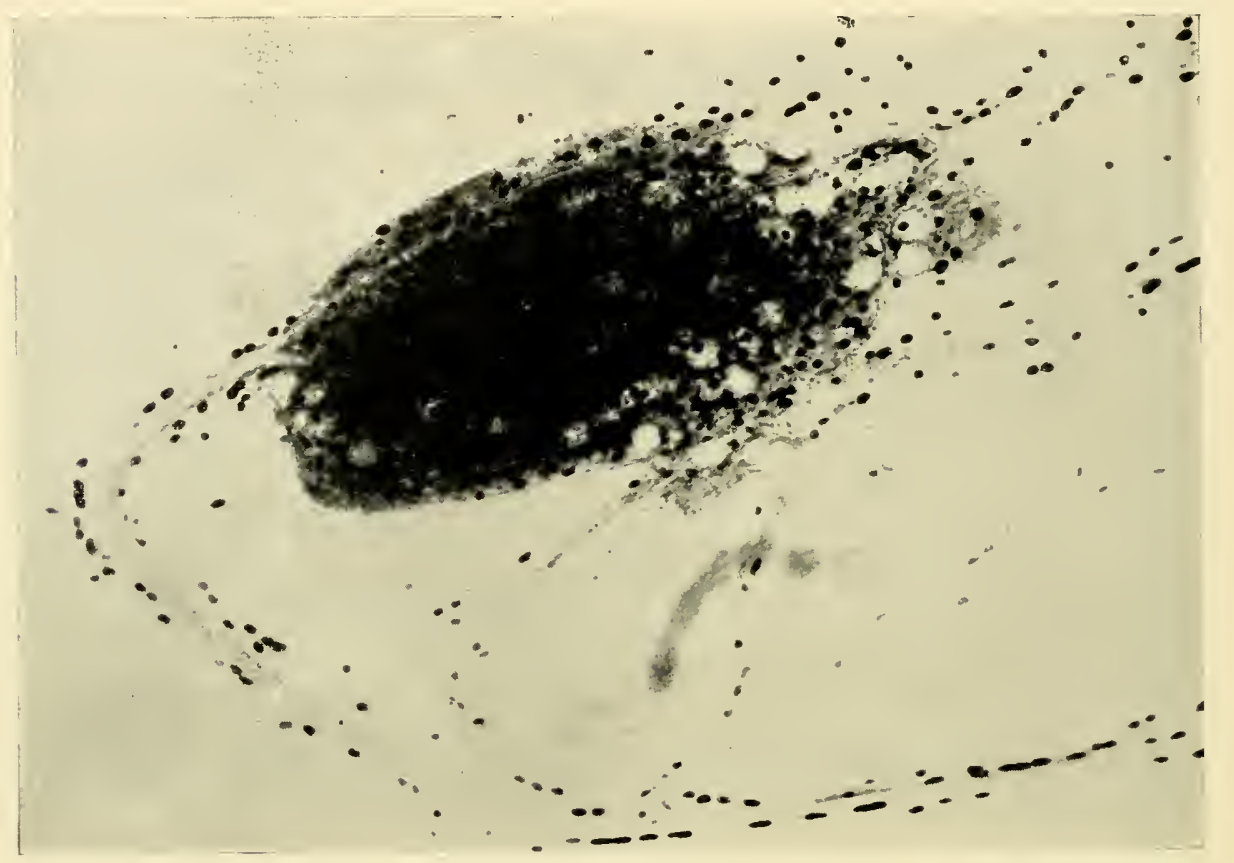

FIG. 15

A milk spot from the omentum. There is a leash of tiny vessels running through the mass of relatively undifferentiated mesenchymal cells which constitutes the "tâche laiteuse". Emerging from this zone are numerous rounded mast cells $(\times 50)$. (Riley (1953), J. Path. Bact. 65, 146.)

cytoplasm which stains orthochromatically, and as the cells enlarge this staining is most pronounced at the poles of the cells. In other cells small granules are present around the nuclear space, and with further development and packing of the granular material the cells gradually assume the appearance of type-I mast cells, except that they are more rounded than the type-I cells seen elsewhere. These type-I cells appear to change progressively into large type-II cells, some of which lie free in the adjacent peritoneum.

\section{Uterine fringes}

In female rats the leaf-like fringes attached to the horns of the uterus furnish excellent preparations for mast cells, as here much of the fat is deposited 


\section{MAST CELLS IN CATTLE AND RAT}

around the edge of the specimen, leaving the branching main vessels almost clear of fat except for their immediate sheath of fibro-fatty tissue. Chains of characteristic type-I cells occur in the adventitia of the main vessels with muscle coats. Type-II cells are scattered around the capillaries or lie free in the loose connective tissue near by. Where the perivascular tissues are lax the transition from type-I to type-II cells can be clearly seen (Fig. 14). In some of these

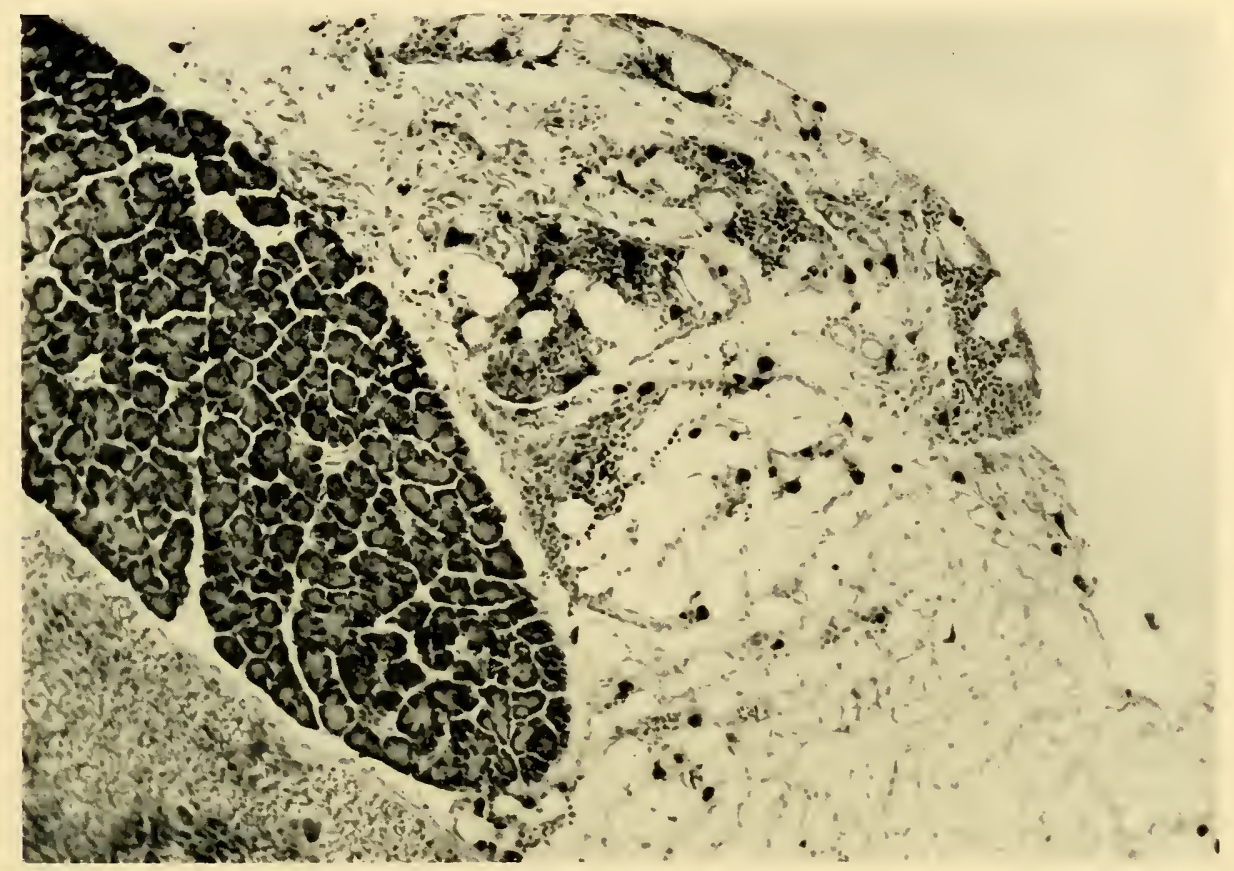

Fig. 16

Section showing ( $\mathrm{L}$ to $\mathrm{R}$ ) spleen, pancreas and loose subperitoneal connective tissue in the rat. The mast cells are related to the loose connective tissue. Toluidine blue $(\times 116)$.

fringes typical milk spots and smaller nodules of similar tissue are found tucked away among the fat cells, and, where such tissue is present, mast cells in all stages of development can be observed.

\section{Degenerate cells}

In spreads from all areas there are occasional type-II cells which appear to be degenerating. The commonest sign of ageing is a generalized fading of the metachromatic granules in the large type-II cells. In other cells this change is accentuated by the presence of a few granules which stain exceptionally deeply, giving the cells a characteristic punctate appearance. Other cells are shrunken, the remaining granules lying near the periphery of the cell, in the 
THE MAST CELLS

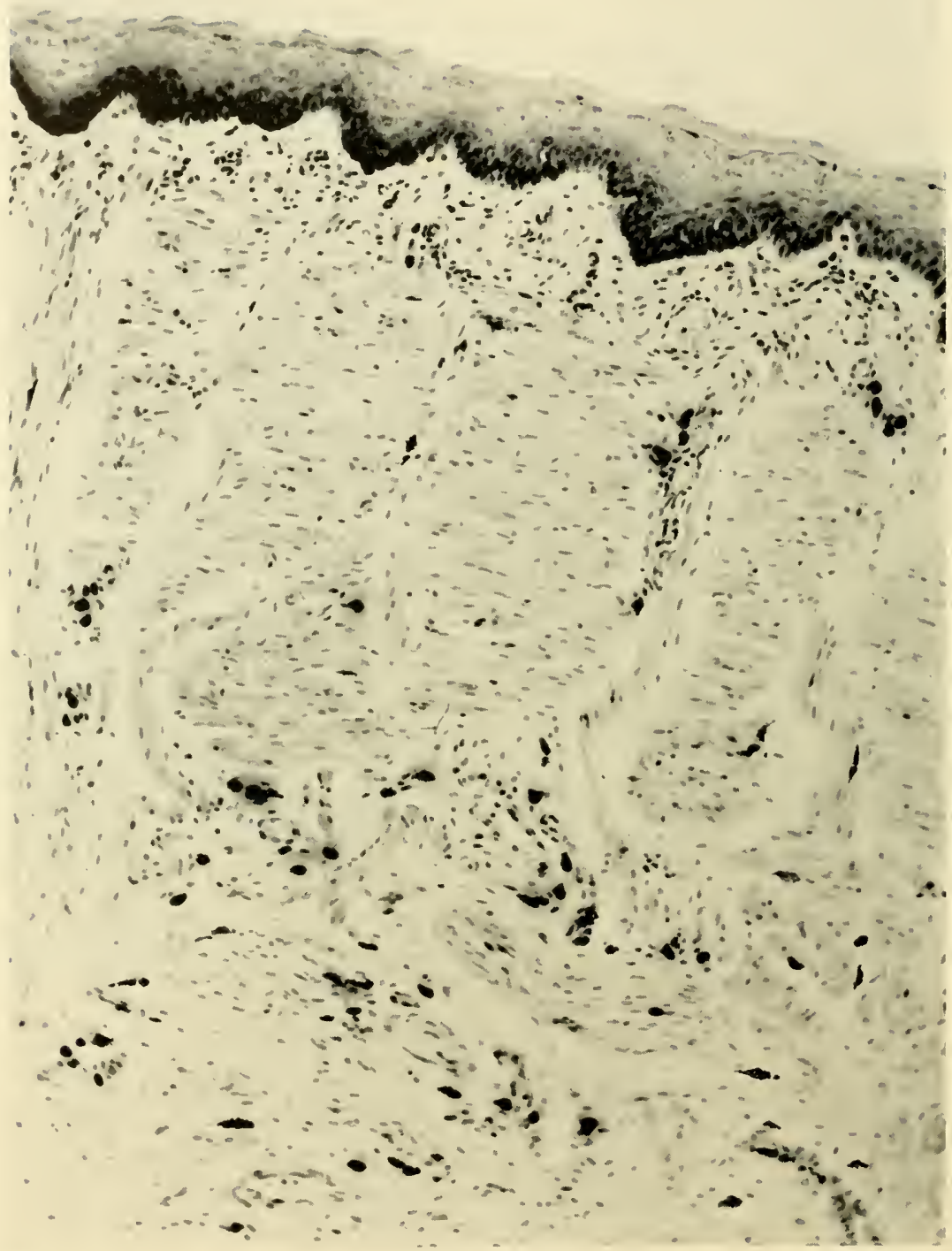

FIG. 17

Section, rat tongue. Note that here the mast cells lie deeply between the muscle bundles. There is little loose connective tissue under the epithelium of the tongue (which cannot be lifted off the muscle) and there are very few mast cells in the region. Toluidine blue $(\times 170)$. 
centre of which a small pyknotic nucleus can occasionally be seen. These degenerate cells are usually situated at some distance from the nearest vessel (Figs. 13, 14).

\section{DISCUSSION}

Examination of stained tissue spreads of subcutaneous connective tissue, mesentery, omentum and the uterine fringes from female rats leaves no doubt

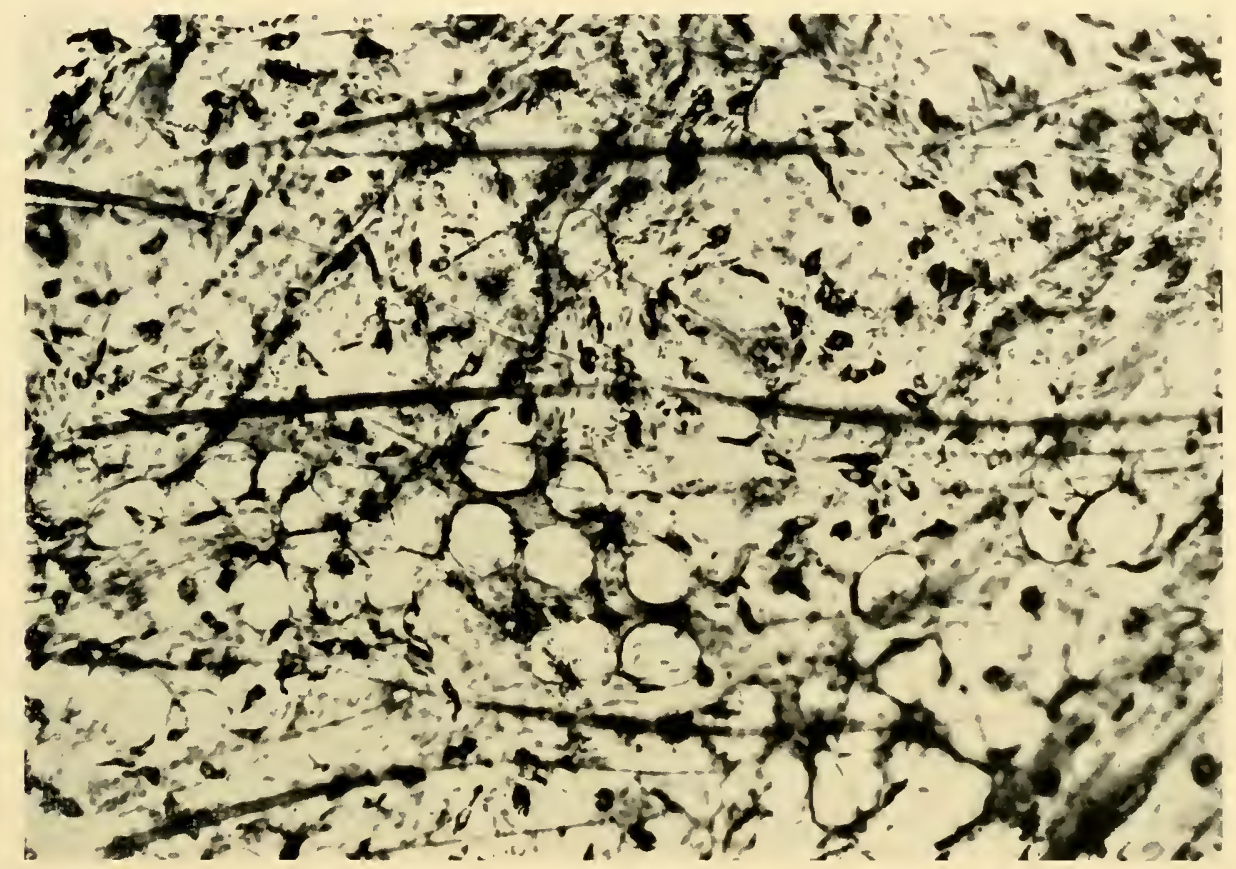

FiG. 18

Whole mount preparation, outer skin and subcutis, of rat ear. Numerous mast cells around hair follicles and in loose connective tissue, as in mouse ear (fig. 56). Toluidine blue ( 128).

as to the close association of the mast cells with the blood vessels in this species. On the other hand, it does call in question certain views which are widely held regarding the exact relationship of the mast cells to the vessels, and hence casts doubt upon the deductions that have been made from such observations.

In his book on Heparin, Jorpes (1946, p. 64) quotes Quensel (1933) that mast cells are situated predominantly around 'thin-walled blood vessels which lack muscle coats', thereby strengthening his belief that the function of the mast cell is to produce an anticoagulant which is poured into the blood. His accompanying illustrations do not entirely support this view. In his Figures $1 a-1 b$ (facing p. 60) the transition from Type I to Type II mast cells is clearly seen-small spindle-shaped orthochromatic cells in the vessel wall developing 
into larger metachromatic cells in the nearby connective tissue. His Figure 8 (p. 65) shows a tissue spread from a rat in which the majority of the cells are disposed, as I have described them, outside the muscle coat of a small arteriole. Both Waldeyer (1875, Fig. 1) and Ehrlich (1877, Fig. 8) depict a similar arrangement of mast cells in the adventitia of blood vessels: yet Ehrlich believed the mast cells to be concerned with the nutrition of the connective tissue. Thus very similar illustrations have been submitted in the past in support of two entirely different functions of the tissue mast cells.

So far as the present investigation is concerned, the evidence both from cattle and rats indicates that although mast cells are very common around small blood vessels, their number is determined more by the extent to which such vessels are equipped with an adventitial coat of mesenchymal cells than with a functional relationship between the mast cells and the contents of the vessels. One layer or more of muscle usually separates the mast cells from the lumen, and, as the cells mature, they tend to move even farther away from the vessels into the tissues. This is well seen in the rat. The available evidence thus suggests that the presence of mast cells in the adventitia of small blood vessels is, in fact, no different from their presence around the great veins and arteries. and that this is merely an extension of conditions which obtain in the subserous connective tissue of the nearby pericardium. Pericardium, in turn, resembles pleura, or liver capsule, or peritoneum, all of which are rich in mast cells. This is best seen in cattle. Similar loose connective tissue contributes to the formation of the capsules and trabeculae of organs anatomically remote from the serous membranes: it occurs in the submucosa of the gut and fills the chinks between the bundles of voluntary muscles. Such tissue underlies the synovia of joints and can be found also in the joint capsule. It underlies surface epithelium, especially where that epithelium can be moved freely over the corium; it is, in fact, the cause of that mobility. In short, the common denominator which determines the presence of mast cells in an organ is the extent to which that organ contains loose, well-vascularized connective tissue. Hence it seems very probable that the mast cell is itself related functionally to the connective tissues, and more especially to connective tissue at one particular stage of its development, the stage of fibrillogenesis (Staemmler, 1921). 


\title{
THE EFFECTS OF HISTAMINE-LIBERATORS ON THE MAST CELLS OF THE RAT
}

(See Riley, 1953b)

\begin{abstract}
T $\mathrm{N}$ the introductory statement of the reasons for choosing the functions of the tissue mast cells as a subject for research, it was argued that circumstantial evidence is already available which points to the mast cell being at least one of the sources of tissue histamine. The main reservoir of both heparin and histamine in the dog is thought to be the liver, the 'shock organ' of this species (Rocha e Silva, 1952), and the heparin moiety is generally attributed to the mast cells which are abundant in the liver of the dog (Wilander, 1938). The apparent absence of heparin in states of shock in other animal species at first sight suggests that in the dog the association of heparin and histamine is fortuitous, but the application of histamine-liberators to the rat now to be described indicates that in this species too there may well be a closer relationship than has as yet been realized and that histamine as well as heparin may come from a common source, the tissue mast cells.
\end{abstract}

\section{Materials and methods}

Experimental animals. Adult male and female rats of the Wistar strain, wt. 175-225 g., were used.

SOLUTIONS FOR INJECTION. The histamine-liberators and the concentrations in which they were given by intravenous injection are shown in the accompanying table.

\section{TABLE I}

Chemical histamine-liberators: sources and dosage

\begin{tabular}{|c|c|c|}
\hline Histamine-liberator & Maker & $\begin{array}{l}\text { Dose }(\mathrm{mg} \text {. } \\
\text { per } 1.0 \mathrm{ml} \\
\text { water })\end{array}$ \\
\hline $\begin{array}{l}\text { Stilbamidine } \\
\text { 2-hydroxy stilbamidine } \\
\text { Propamidine } \\
\text { Pentamidine } \\
\text { Heptamethylene diamine } \\
\text { hydrochloride } \\
\text { Decamethylene diamine } \\
\text { hydrochloride } \\
\text { D-tubocurarine chloride } \\
\text { Peptone }\end{array}$ & $\begin{array}{c}\text { May \& Baker } \\
, " \\
, " \\
\text { Imperial Chemical } \\
\text { Industries }\end{array}$ & $\begin{array}{c}25 \\
25-27 \\
50 \\
50\end{array}$ \\
\hline
\end{tabular}


All compounds were made up fresh in pyrogen-free distilled water, and a standard volume $(1 \mathrm{ml}$.) of solution was employed for each injection.

Doses of the more toxic compounds (diamidines and curare) were chosen experimentally to produce $(a)$ death of a $200 \mathrm{~g}$. rat in 5-10 seconds or $(b)$ a survival time of about 3 minutes, depending on the speed with which the intravenous injection was given. Thus the histamine-liberators themselves were used to halt the train of events in the tissues and permit the material to be examined at various stages of the shock which had been induced. This method had the further advantage with the fluorescent diamidines (stilbamidine and 2-hydroxy stilbamidine) of ensuring that sufficient diamidine was present in the tissues for its detection in fresh tissue spreads examined in ultra-violet light. With the less toxic compounds (diamines and peptone) the experimental animals were killed by a blow on the head at appropriate intervals after injection.

PrePARATION AND STAINING OF TISSUES. Immediately after the experimental animal had been killed, spreads of subcutaneous connective tissue, mesentery, omentum and other peritoneal fringes were prepared as previously described. If fluorescent histamine-liberators had been used the fresh spreads were first examined microscopically in ultra-violet light from a Hanovia diagnostic lamp with a Wood's glass filter directed obliquely downwards on to the surface of the spread. Thereafter these and all other spreads were fixed in 80 per cent alcohol for at least twenty-four hours before being stained with 1 per cent aqueous toluidine blue or methylene blue for mast cells.

\section{RESULTS}

\section{Fluorescent histamine-liberators}

Group A. Rapid injection. Fresh peritoneal spreads from animals killed by rapid $(5 \mathrm{sec}$.) injection of lethal doses of stilbamidine or 2-hydroxy stilbamidine were examined microscopically under direct ultra-violet light (Fig. 19). Against a dark background, or at most a faint autofluorescence from the fat globules, one sees numerous bright, sharply defined fluorescent spots situated predominantly near small blood vesseis. With stilbamidine the spots are a steely blue-grey; with 2-hydroxy stilbamidine, a more golden colour. Occasionally the whole vessel seems to fluoresce, presumably from its content of diamidine, or the vessel wall alone is visible in a pale violet tint. The remaining vessels appear as dark lines. If 1 per cent toluidine blue in saline is now run on to the preparation the fluorescence immediately disappears. The section is not moved, but visual light is now transmitted through the specimen, and it is seen that where the fluorescent spots were situated there are recognizable tissue mast cells (Fig. 20). The correspondence in size and position is very exact 


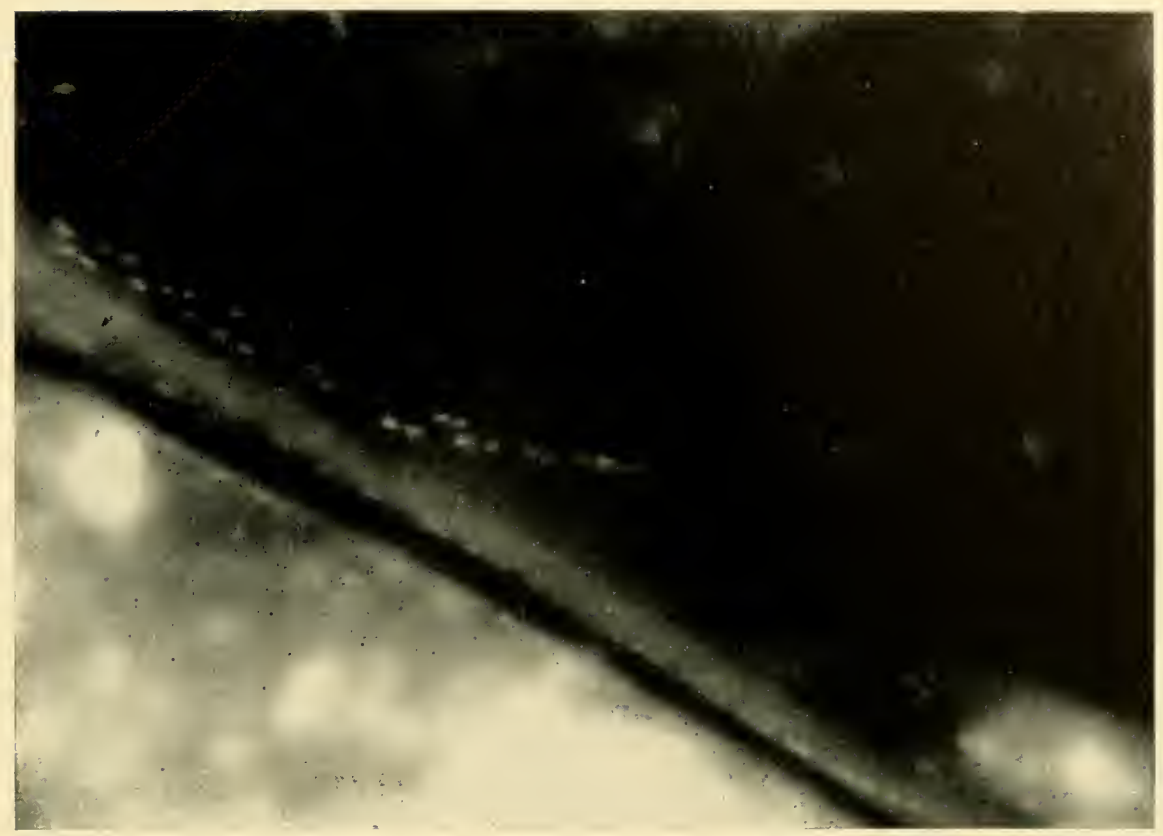

FIG. 19

Fresh peritoneal spread from a rat killed by the rapid injection of stilbamidine. The bright spots thuorescing in ultra-violet light are seen, in fig. 20, to be mast cells in which the fluorescent stilbamidine has concentrated. This substance is also present in the lumen of the upper vessel ( . 70). (Riley (1953), J. Path. Bact. 65, 471.)

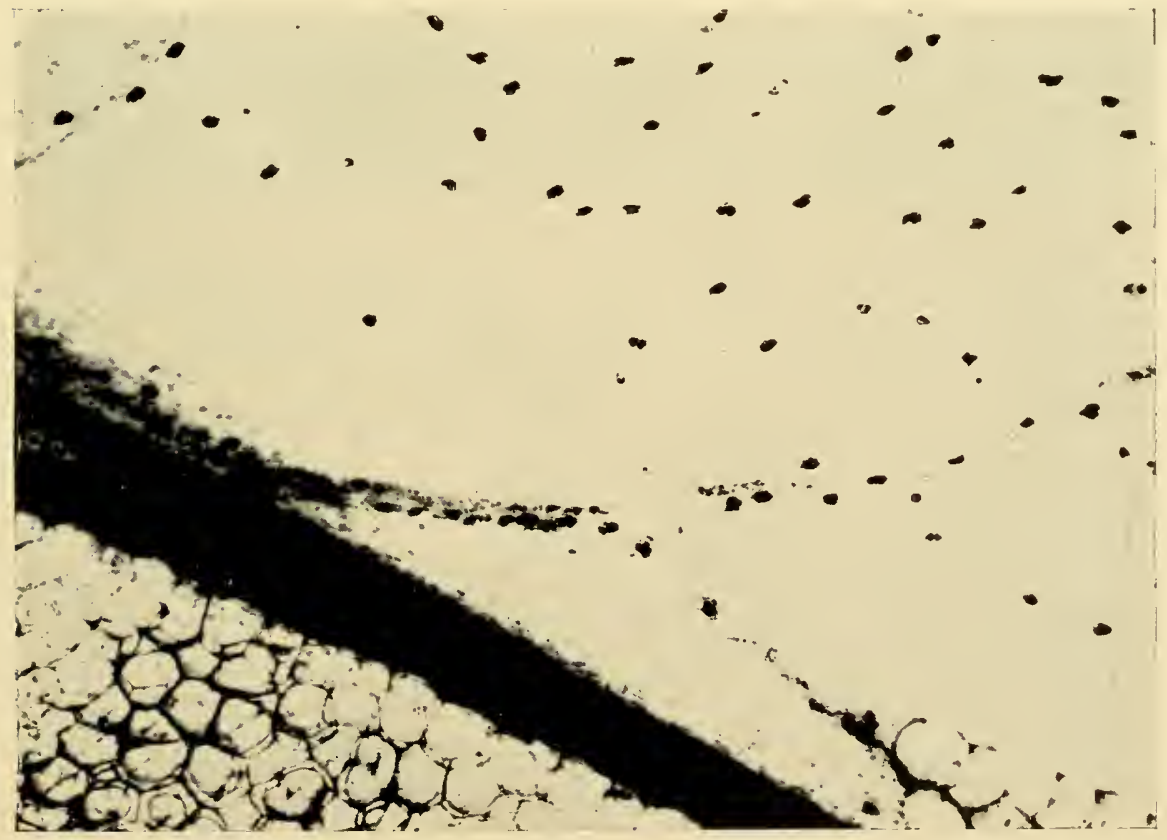

FIG. 20

The same spread as fig. 19, now counterstained with methylene blue and photographed in visible light minus the red filter. The dark mast cells correspond exactly with the fluorescent spots of the previous figure $(\times 70)$. (Riley $(1953)$, J. Path. Bact. 65, 471.) 
as far as the fluorescent bodies are concerned, but the toluidine blue reveals many mast cells which had not previously shown fluorescence. In general, the mast cells which took up the diamidine in the short-term experiment are the large, pericapillary metachromatic mast cells, recognized as adult or ripe mast cells ("type-II cells"). These fluorescent type-II cells are well seen in the peritoneal interspaces of the mesentery and in the fatty fringes attached to the

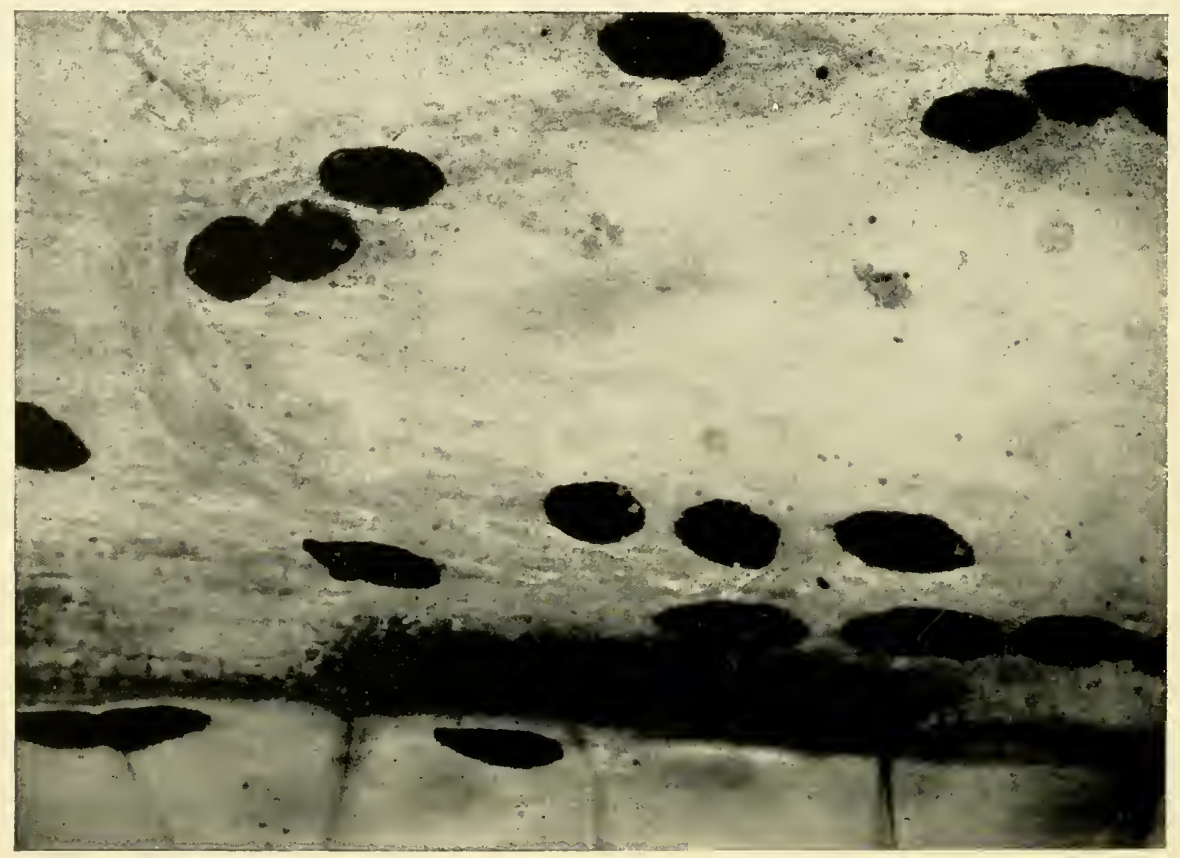

FIG. 21

Fatty uterine fringe from rat killed by the slow intravenous injection of 2 -hydroxy stilbamidine, stained with toluidine blue. The young type-I mast cells in the adventitia of the main vessel appear normal, but vacuoles are already forming in the more mature type-II cells near the capillaries. Had the animal survived longer these type-II cells would have undergone complete disruption $(\times 455)$. (Riley (1953), J. Path. Bact. 65, 471.)

uterine horns. So far as can be ascertained the fluorescence is confined to the granular cytoplasm of the mast cells, the nucleus being sometimes represented by a central non-fluorescent space. In the omentum the fluorescent mast cells appear principally in the milk spots ('tâches laiteuses'), and here practically every mast cell in one milk spot may show fluorescence, whereas an adjacent milk spot may be devoid of fluorescence. It is noteworthy that under the conditions of the present experiments fluorescence is not observed in the numerous mast cells in the subcutaneous connective tissue, although as judged by ordinary staining methods all types of mast cells are present there. 
Group B. Slow injection. Following slow $(30-60 \mathrm{sec}$.) injection of these diamidines an entirely different picture is seen. Instead of the sharply defined fluorescence of mast cells in the peritoneal tissues there are pools of pale grey to gold fluorescent material around some of the vessels, with perhaps some increase of fluorescence in the nearby fat. Counterstaining with toluidine blue, as above, reveals that there is widespread disintegration of the mast cells, and routine fixation and staining of spreads from these animals confirm the disintegrating effect on the mast cells of the diamidines. Individual granules are swollen and stain poorly, and are often scattered. In addition some cells show vacuolation. This is best seen after 2-hydroxy stilbamidine. Here many of the type-II mast cells in the peritoneal spreads show the presence of intracytoplasmic vacuoles, whereas nearby type-I cells may remain unchanged (Fig. 21). As the injection time, and hence the survival time, of the experimental animal is increased, it can be seen that this vacuolation progresses until many of the cells entirely disappear or leave behind only a few granules surrounded by a wisp of frothy cytoplasm. In areas where these changes in mast cells are prominent the small blood vessels are dilated and the connective tissue appears oedematous.

In animals which have survived for more than a few minutes, extensive areas of vasodilatation and oedema are present, and in such regions the mastcell granules gradually lose their ability to take on the basic stain ("degranulation'). Some of the degranulated cells are swollen; others show in addition a characteristic punctate appearance in which a few granules appear to have escaped lysis and stand out in sharp contrast to the pale cytoplasm. Where the oedema is maximal no trace of the former mast-cell population of the tissue may remain.

\section{Non-fluorescent histamine-liberators}

The changes produced in the mast cells by the non-fluorescent histamineliberators (table) as seen in stained spreads are very similar to those described above.

Propamidine and Pentamidine give rise to occasional vacuolation and widespread degranulation in peritoneal mast cells as does the 10-carbon aliphatic diamine, and there is also some degranulation in the mast cells of the subcutis. The 7-carbon diamine, which is less active as a histamine-liberator than the 10-carbon compound (MacIntosh and Paton, 1949), is also less potent in its effect on mast cells.

The injection of Witte's peptone produces similar degranulating and disintegrating effects on the mast cells of the rat, despite the fact that in this species peptone does not give rise to the dramatic shock seen in the dog. 
One of the most active disintegrators of the rat's mast cells was found in d-tubocurarine in lethal dosage, which, as Schild and Gregory (1947) have shown, can also liberate histamine. Following slow injection of $5 \mathrm{mg}$. d-tubocurarine chloride (Duncan), not only is it difficult to find a mast cell in the peritoneal spreads but there is also extensive oedema and associated degranulation of mast cells in the subcutaneous tissue.

\section{Histamine}

In an attempt to distinguish between the effects on mast cells of histamineliberators and the histamine which is liberated, rats were injected intravenously with $1 \mathrm{ml}$. doses of histamine dihydrochloride (British Drug Houses) in concentrations ranging from 1 in 100,000 to 1 in 5 . Only with the highest concentrations were gross changes observed in the mast cells, and these only in the areas of vasodilatation and tissue oedema produced by the histamine, especially in the peritoneum. None of the mast cells showed gross vacuolation.

\section{Non-specific oedema}

Some years ago it was found that the application of a light venous tourniquet to the hind limbs of mice was followed within twenty-four hours by an almost complete disappearance of mast cells from the oedematous skin (Drennan and Riley, unpublished observation). Since then Drennan (1951) has studied human skin in a state of oedema and found there also a similar disappearance of mast cells. The use of histamine, mentioned above, may thus have brought about its effect on the mast cells by the production of a local oedema rather than directly. It was decided therefore to produce a local oedema by other methods.

Local oedema was produced in rats by (1) scalding one side of the back, under anaesthesia, with water at $95^{\circ} \mathrm{C}$., or (2) heating the area for thirty minutes with an infra-red lamp. In these areas of local oedema of the underlying subcutaneous tissue there is obvious degranulation of the tissue mast cells. In the oedematous zone due to scalding many of these cells have a homogeneous 'glassy' appearance as if the granule substance had run together, and in some of them occasional irregular vacuoles are also present. The degranulating effect is seen only in the area rendered oedematous; there is no effect, for example, on the peritoneal cells remote from the oedematous area.

It may be concluded then that the local degranulation of mast cells in areas of oedema is different in quantity and in quality from the widespread vacuolation and disruption of mast cells which follow the injection of a histamineliberator. However, if the liberator is injected slowly, there will be time for both processes to occur and a mixture of effects will be seen. 


\section{Anaphylatoxin}

Since the action of histamine-liberators on the dog so closely resembles anaphylactic shock in that species, it seemed of interest to attempt to relate the mast cells and anaphylaxis in the rat. Unfortunately, the rat can hardly be rendered anaphylactic, but the problem was approached by the use of an anaphylatoxic serum. This was prepared exactly as described by Bordet (1913), except that in place of guinea pig serum five parts of rat serum were incubated

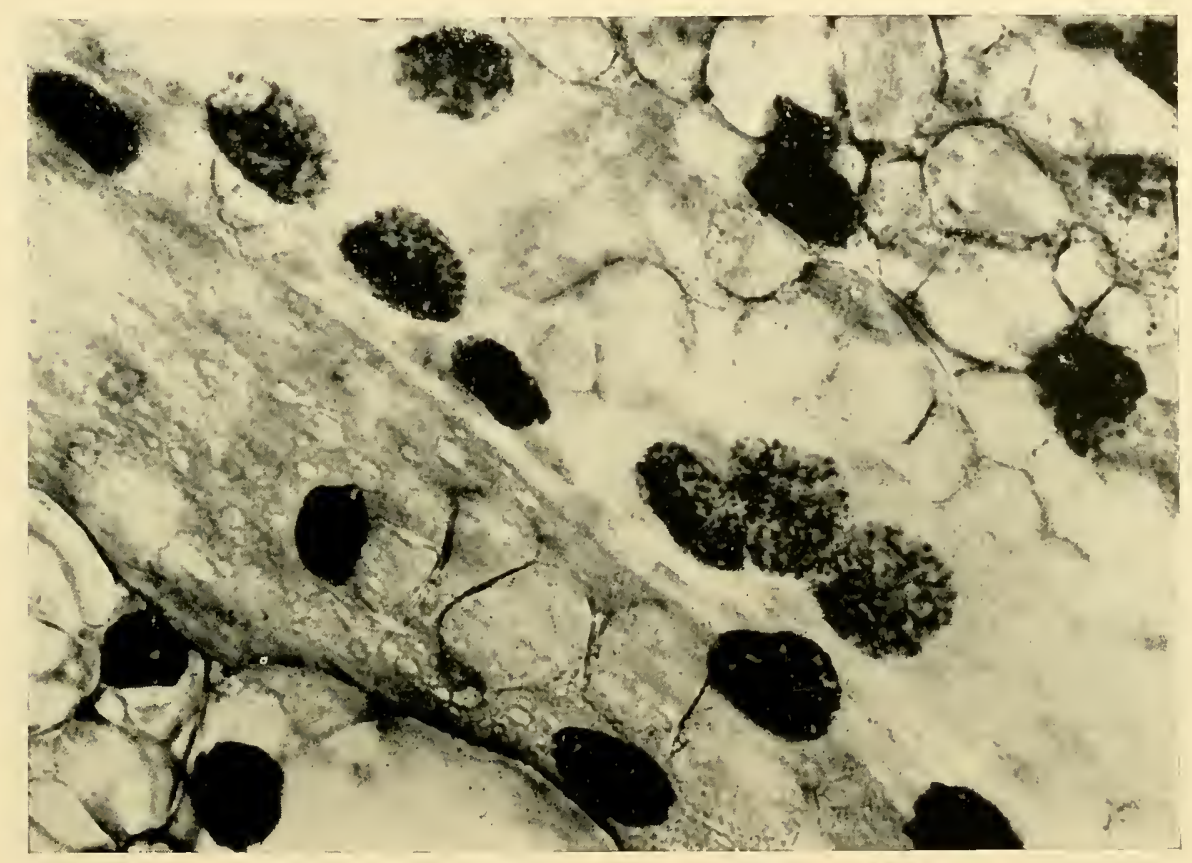

FIG. 22

Mesentery of rat killed four minutes after the intravenous injection of anaphylatoxin, stained with methylene blue. A group of mast cells shows abnormal swelling and early degranulation. One of these contains a large vacuole, and early vacuolation is also present in the nearby compact cells, which as yet show little swelling $(\times 510)$. (Riley $(1953)$, J. Path. Bact. 65, 471.)

for two hours at $37^{\circ} \mathrm{C}$. with one part of semi-solid agar. This was then centrifuged and $1.5 \mathrm{ml}$. of the supernatant 'serotoxin' were injected intravenously into each of three rats. The outward signs of shock produced by these injections were a mere temporary acceleration of heart rate and respiration. The animals were therefore killed 3-5 minutes later. Despite the minimal clinical evidence of shock, the appearances in the peritoneal spreads closely resembled those seen after the use of histamine-liberators. Thus nearly all type-II cells in the mesentery were swollen and in process of vacuolation or degranulation, 
the type-I cells being relatively unaffected (Fig. 22). Many similar areas could be found in the uterine fringes and omentum, along with the usual vasodilatation and oedema in the surrounding connective tissue. The mast cells in the subcutaneous connective tissue appeared normal.

The changes in the mast cells after injection of anaphylatoxic serum thus so closely resembled those seen after injection of the chemical histamineliberators that attempts were made to prepare an anaphylatoxin by incubating rat serum with minimal amounts of the liberators in vitro. One $\mathrm{ml}$. of saline containing $0.5 \mathrm{mg}$. of stilbamidine or d-tubocurarine chloride was incubated for two hours at $37^{\circ} \mathrm{C}$. with $5 \mathrm{ml}$. of rat serum; $1.5 \mathrm{ml}$. of each of the final products were thereafter slowly injected intravenously into each of three rats. No shock was produced and there was no alteration in the appearance of the mast cells in tissue spreads. However, since the possibility still remained that the liberators might require leucocytes or platelets not present in serum for their effects on mast cells, another set of sera was prepared by incubating whole blood with the liberators before removing the serum. Again the results were negative.

Thus, although the final effects on mast cells of histamine-liberators and agar-activated serotoxin are similar, it appears that their modes of action are different and that the chemical histamine-liberators do not bring about disruption of mast cells through the agency of a blood anaphylatoxin.

\section{Antihistamines}

According to Dale (1950) antihistamines may act either by blocking tissue receptors to circulating histamine or by interfering with the release of histamine from its depots in the tissues. It was therefore of interest to see if antihistamines would alter the mast-cell response to the histamine-liberators and to the anaphylatoxic serum.

It was first found that the maximal tolerated dose of 'Anthisan' (mepyramine maleate, May and Baker) for a $200 \mathrm{~g}$. rat was $0.2 \mathrm{ml}$. of a 2.5 per cent solution given slowly intravenously. Fifteen minutes after giving this dose to four rats, two of them each received a slow lethal injection of stilbamidine and two were given a slow injection of curare as previously described. Stilbamidine and curare are both toxic substances irrespective of their action as histamineliberators, and premedication with 'Anthisan' in no way reduced the lethal effect of either compound; but it did appear to protect the mast cells almost completely against the disruption which normally followed their injection. However, premedication with 'Anthisan' did not prevent the uptake of stilbamidine by the mast cells, which showed the usual vivid fluorescence in ultra-violet light. Only the subsequent disruption of the cells was suppressed (Fig. 23). 
In a similar way 'Anthisan' countered the disruptive effect on mast cells of the agar-serotoxin. Thus the disintegration of mast cells by both chemical histamine-liberators and anaphylatoxin is prevented by pretreatment with an antihistamine drug.

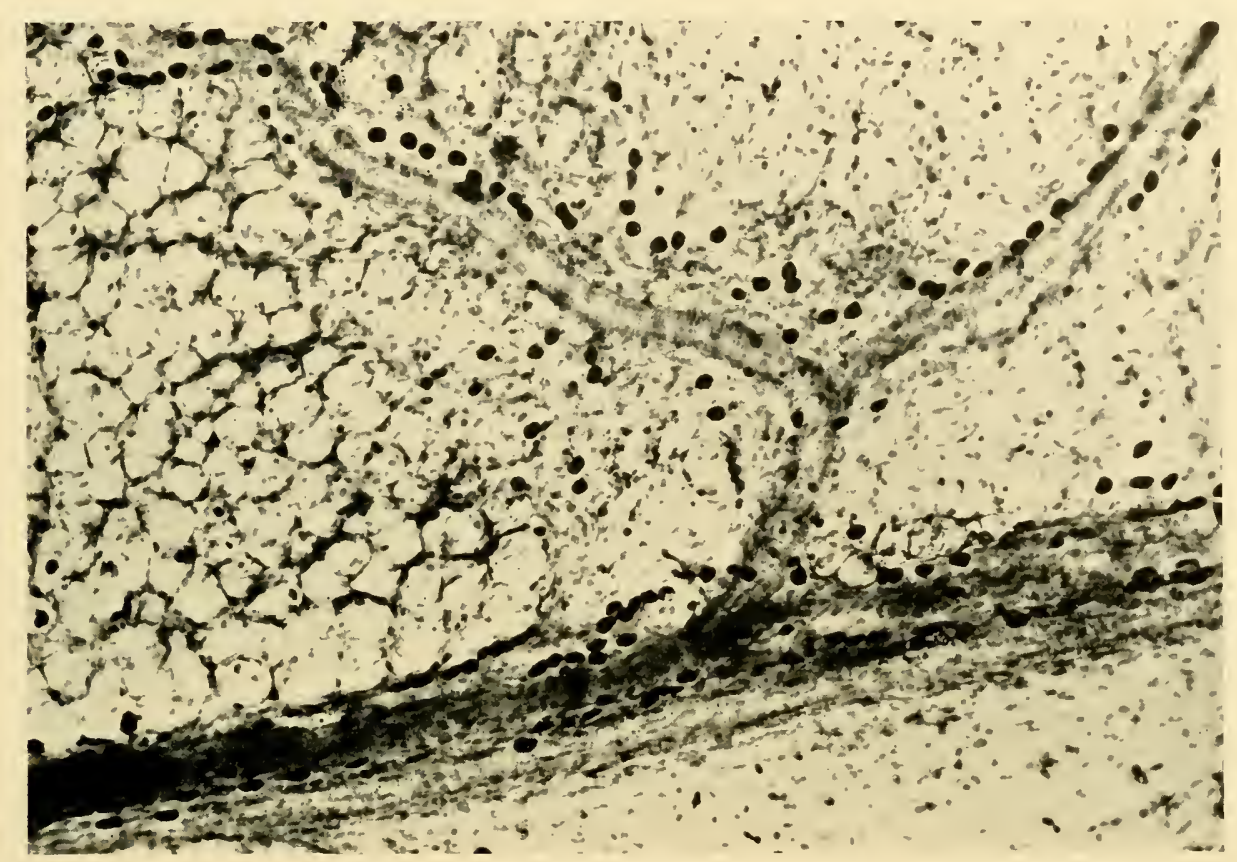

FiG. 23

Tissue spread of uterine fringe from rat treated with an anti-histamine drug before being subjected to the disruptive action of a chemical histamine-liberator. The mast cells have been protected. Toluidine blue $(\times 108)$.

\section{Direct application of histamine-liberators to tissue spreads}

In a further attempt to gain information on the mode of action on mast cells of the chemical histamine-liberators and the agar-activated serotoxin, samples of the various solutions which had been prepared for injection were applied directly to fresh spreads of rat mesentery, using the peritoneal interspaces as cups for holding the solutions under test.

Preliminary experiments soon showed that any aqueous solution, including even normal saline, quickly causes diffusion of the metachromatic material from the granules of mast cells, which later swell and burst, freeing such granules as remain. Despite this limitation of the method, it was observed that the diamidines exhibit the same avidity for mast cells in fresh spreads of mesentery as they do when they reach the cells through the blood stream. If 
the granules had previously been supravitally stained with toluidine blue, the diamidine rapidly discharged the metachromatic dye from the granules, leaving the nuclei of nearby fibrocytes and mesothelial cells still stained. Thereafter the mast cells slowly broke up into a mass of debris, but in general this disruption was neither so rapid nor so clearly accompanied by vacuolation as it had been in tissue spreads prepared from rats which had received the same liberators through the blood stream.

With anaphylatoxic serum well-marked vacuoles appeared in the peripheral cytoplasm of the mast cells accompanied by disappearance of granules, whereas with normal rat serum the granules persisted for at least half an hour. Although it is clear that direct action does occur in vitro, the mast-cell response was less pronounced than when the histamine-liberators or the anaphylatoxic serum reached the mast cells through an intact circulation.

\section{DisCUSSION}

The reasons for the present investigation have already been outlined. Briefly it may be recalled that in shock states in the dog histamine and heparin are released simultaneously from the liver, the heparin being thought to come from tissue mast cells. It was of interest, therefore, to investigate the relation of mast cells to histamine in an animal such as the rat, where the mast cells can be readily observed in tissue spreads.

\section{Chemical histamine-liberators}

All the histamine-liberators tested were found to produce, on intravenous injection in the rat, obvious damage to tissue mast cells and particularly to those peritoneal mast cells, filled with discrete, metachromatic granules, which lie near capillaries or free in the tissue spaces (type-II cells). However, interpretation of this apparently straightforward effect is complicated by the finding that any tissue oedema, including that produced by the injection of histamine itself, leads to disruption of the mast cells in the area. We have, therefore, to distinguish between a primary action of the liberators directly on mast cells and the indirect or secondary degranulation of mast cells mediated through the oedema that follows histamine release.

\section{Direct action on mast cells}

Direct action of the histamine-liberators on the mast cells is certainly suggested by the following observations. First, the rapidly acting and potent histamine-liberators, stilbamidine and 2-hydroxy stilbamidine, can be seen, in virtue of their fluorescence in ultra-violet light, to be concentrated within 
the peritoneal mast cells prior to their disruption. Second, the fluorescent histamine-liberators, when applied to fresh spreads of peritoneum from intravitally stained animals, rapidly discharge the dye from the granules, after which the mast cells disintegrate. Third, all the histamine-liberators so far tested, whether fluorescent or not, lead to the appearance of curious intracytoplasmic vacuoles, and with 2-hydroxy stilbamidine vacuolation may be extreme. In contrast to this, swelling and degranulation of mast cells are unaccompanied by vacuolation when brought about by $(a)$ local oedema, histamine-induced or otherwise, or $(b)$ the addition of aqueous solutions to mast cells in fresh tissue spreads. It is evident, therefore, that the histamineliberators have a definite effect on both cytoplasm and granules of the mast cell.

The concentration of the chemical liberators within the mast cells may well depend on the fact that the basic diamidines precipitate heparin from solution (MacIntosh and Paton), and one may recall here that the dye, toluidine blue, can be similarly used for the quantitative titration of heparin. But with the chemical histamine-liberators the process does not stop there; disintegration of the mast cell follows. Thus the diamidines act on mast cells in a different way from a basic dye such as toluidine blue, which, if anything, preserves rather than destroys the granules which have taken up the dye. If, therefore, as MacIntosh and Paton suggest, chemical histamine-liberators act by displacing histamine from its natural depots in the tissues, the present evidence suggests that these depots are the tissue mast cells.

\section{Effect of anaphylatoxin on mast cells}

Agar-activated anaphylatoxin, prepared as described above, is a known histamine-liberator (Rocha e Silva) and in the present experiments its visible action on mast cells proved similar to that of the chemical liberators, even to the appearance of vacuolation in the cells during their disruption. Anaphylatoxin has also the same power of acting topically when applied directly to mast cells in fresh tissue spreads. Thus we have two apparently different types of substance capable of releasing histamine, both of which produce very similar changes in mast cells. It therefore seems probable that these changes in the mast cells are significantly related to the liberation of histamine.

We now know that these changes do, in fact, occur in true anaphylaxis (Stuart, 1952). The earlier observations of Jaques and Waters (1941) on the degranulation and disruption of mast cells in the liver of the shocked dog have been confirmed for mast cells in the tissues of the hamster (Wegelius et al, 1955b), guinea pig (Mota and Vugman, 1956), mouse (Carter et al, 1957) and rat (Keller, 1957). This further strengthens the view that the findings in the experiments described above are relevant not only to the study of the 
anaphylactic process generally, but that the mast cell is the common target whenever a massive liberation of tissue histamine occurs.*

\section{Effect of antihistamines}

Antihistamines are thought to act either by blocking tissue receptors against circulating histamine or by preventing the release of histamine (Dale). Unfortunately, the actual mechanism is not yet known. Nevertheless, it is of interest that premedication of rats with an antihistamine effectively protects the mast cells against the disruptive action of histamine-liberators or anaphylatoxin. In this at least the results support the view, stated in the previous paragraph, that the changes in the mast cells brought about by histamineliberators are significantly related to the phenomenon of histamine release.

* It should perhaps be noted here, as Sir Henry Dale (1954) points out, that the anaphylactic process in the rabbit follows a somewhat different pattern: the reaction occurs in the blood rather than in the tissues. The rabbit is also exceptional in that the bulk of its histamine is located in the blood platelets (Schayer and Kobayashi, 1956; Waalkes et al, 1957). 


\section{HISTAMINE IN TISSUE MAST CELLS: NORMAL TISSUES}

\section{RESULTS OBTAINED BY COMBINING HISTOLOGICAL AND PHARMACOLOGICAL TECHNIQUES}

$\mathrm{T}$

HE evidence cited in the previous section indicates that the tissue mast cells of the rat undergo profound morphological changes following contact with chemical histamine-liberators. It is now necessary to ascertain whether the mast cells are in fact the source of the histamine which is released during this reaction: in other words, are the initial values for histamine in normal tissues proportionate to their mast-cell contents, and do these values vary with the morphological changes in the mast cells which follow the administration of the chemical histamine-liberators?

It will be recalled that Jorpes used the first of the above criteria in seeking the location of heparin in the tissues. We therefore first confirmed the mastcell contents of the tissues used by him, for which the corresponding heparin values are also available (Jorpes, 1946), and estimated their histamine contents (Riley and West, 1953).

\section{Materials and methods}

All material was obtained fresh, either at the slaughter-house or in the laboratory. Tissue blocks for mast cells were fixed, as before, in formol corrosive and stained with toluidine blue.

Representative samples of fresh tissue for histamine assay were weighed and placed as soon as possible in a known volume of 10 per cent trichloracetic acid, usually $1 \mathrm{ml}$. acid per $1 \mathrm{~g}$. tissue, or twice that volume of acid if the tissue was not adequately covered. Thereafter the tissue was chopped with scissors, or if tough, ground with a little sand in a mortar, to ensure complete extraction of the histamine into the acid. After a minimum period of one hour the extract was centrifuged and the clear supernatant then shaken vigorously four times with a fourfold volume of ether (or shaken further if the $p \mathrm{H}$ was still below $6 \cdot 0$ ) in order to remove the acid.

The assay itself was made against a standard solution of histamine acid phosphate $\left(10^{-3}\right)$ either on the conventional guinea pig ileum preparation or on the blood pressure of the atropinized cat. All values are expressed as $\mu \mathrm{g}$ histamine base per gram wet weight of tissue. 


\section{RESULTS}

It will be seen from Table II that there is indeed a striking correspondence between the histamine values on the one hand and the mast-cell, or heparin, contents as indicated by Jorpes' data, on the other. This at once provides powerful support for the hypothesis that tissue mast cells are exceptionally rich in histamine. Much of the remainder of this book is concerned with the description of the further experimental procedures which were devised to test and consolidate this basic premise.

TABLE II

Histannine content (ug./g.) of tisstes compared with heparin content (mg. standard heparin'kg.) and the relative mast-cell content

\begin{tabular}{|c|c|c|c|}
\hline Tissue & Histamine & Heparin* & Mast cells \\
\hline Rat liver. & $0 \cdot 3$ & 0 & 0 \\
\hline Pig aorta . & $0 \cdot 7$ & 0 & 0 \\
\hline Ox-liver parenchyma & $4 \cdot 5$ & $56-75$ & + \\
\hline Ox aorta & $10 \cdot 0$ & $5-65$ & + \\
\hline $\begin{array}{l}\text { Rat subcutaneous } \\
\text { tissue }\end{array}$ & 16.0 & 63 & +1 \\
\hline Ox inferior vena cava & $20 \cdot 0$ & $100-120$ & ++ \\
\hline Ox-liver capsule. & $40 \cdot 0$ & $540-830$ & $++t$ \\
\hline
\end{tabular}

* Data of Jorpes (1946)

\section{Ox liver capsule}

When these preliminary results were reported (Riley and West, J. Physiol., 117: 72P, 1952) the histamine value for ox liver capsule had been obtained from specimens which comprised the outermost rind of the liver, a layer of tissue approximately $0.5 \mathrm{~cm}$. thick containing both capsule and parenchyma. However, paraffin sections show beyond doubt that the mast cells are located almost exclusively in the serous and immediately subserous tissue of the true capsule (Fig. 5). Attempts were therefore made to obtain purer samples of the capsule and to compare their mast-cell and histamine contents.

It was eventually found that the key to the successful removal of the capsule of ox liver is to strip the capsule off the intact liver as soon as possible after its removal from the animal. An incision is made through the capsule around the edge of the dome; and once the process of stripping has been started it is then easy to peel off the entire capsule, the remainder of the organ (which weighs up to $30 \mathrm{lbs}$.) acting as a counter-weight. The thin film of parenchyma which still adheres to the under surface can be removed by spreading the capsule, serous side down, on a sheet of plate glass and scraping the under surface vigorously with a razor blade. The final product is a tough, semi-transparent 
sheet of tissue up to 2 feet square which is extremely rich in both mast cells (Fig. 6) and in histamine. As Table III indicates, the histamine value rises with each successive step in isolating the tissue which contains the mast cells.

TABLE III

Partition of histamine between parenchyma and capsule of ox liver. The mast cells are also predominantly in the capsule (cf. Figs. 5 and 6)

\begin{tabular}{|l|c|c|}
\hline Ox liver & $\begin{array}{c}\text { Thickness } \\
(\mathrm{m.m.})\end{array}$ & $\begin{array}{c}\text { Histamine content } \\
(\mu \mathrm{g} . / \mathrm{g} .)\end{array}$ \\
\hline Parenchyma alone . & - & 5 \\
Capsule with some parenchyma . & $5 \cdot 0$ & 40 \\
Stripped capsule, little parenchyma & $1 \cdot 0$ & 100 \\
Capsule alone . & 0.5 & 180 \\
\hline
\end{tabular}

\section{Estimation of histamine content per mast cell in ox liver capsule}

An estimate of the histamine content of the individual mast cell in ox liver capsule was arrived at as follows. Rectangles of cleaned liver capsule were cut out with a sharp scalpel around a $6 \times 8 \mathrm{~cm}$. rectangle of 'Perspex'. These samples were then weighed, extracted and their histamine contents estimated. Adjacent strips from the same capsule were mounted as tissue spreads on microscope slides, sufficient tissue being draped over the edges of the slide to prevent shrinkage of the spread during fixation and staining.

A horizontal projection microscope was next set up in a darkened room to throw an image of a portion of a prepared spread on to white paper on which, for convenience, a rectangle had been drawn proportionate to the size of the rectangles of tissue used for the pharmacological assays. The actual size of the rectangle in the microscope field was measured by replacing the histological preparation with a stage micrometer, a slide on which a scale in absolute units is engraved for projection at any selected magnification.

However, mast cells are so numerous in ox liver capsule (Fig. 6) that difficulty was encountered not only in transmitting sufficient light through the specimen to show up the individual cells on the paper but also in counting them in the darkened room with any degree of accuracy. This was overcome by throwing a second beam of ultra-violet light on to the paper and covering the image of each mast cell as it was counted with a dot of fluorescent paint. As a check, these dots were again counted by serially quenching their fluorescence with drawing ink, ten fields, chosen at random, being counted twice over for each tissue spread.

In this way the number of mast cells in a sheet of tissue of known histamine content was obtained, calculation then showing each mast cell in ox liver capsule to contain approximately $25 \mu \mu \mathrm{g}$. histamine base. In a later experiment 
the thin liver capsule from a two-months'-old calf, in which the mast cells are fewer and smaller (Fig. 7) and the histamine content per gram is less than in the adult, gave a histamine value of $18 \mu \mu \mathrm{g}$. histamine base per cell.

\section{Mast cells and histamine in other species (See Riley and West, 1953)}

Once satisfactory evidence had been obtained for the localization of tissue histamine in the mast cells of cattle it seemed desirable to see how far this concept could be applied to the cellular location of histamine in the mast cells of other species.

Apart from the figures given by Jorpes (1946; and Table II) there is little information in the literature about the heparin content of various tissues. A comparison was therefore made between the histamine and mast-cell contents of some of the tissues analysed by Holmgren and Wilander (1937) for ester sulphates, these values being assumed by them to represent heparin if other sulphate-containing mucopolysaccharides are absent, particularly the chondroitin sulphate of cartilage. The histamine values and mast-cell contents of the liver of various species, estimated separately as capsule and parenchyma, are given below (Table IV). It should be noted that the values for 'capsule' of ox and cow liver in this table are the values originally obtained before the method of obtaining clean samples had been devised. As mentioned above (Table III), an enormous concentration of mast cells and histamine can be achieved once the difficulties in removing and cleaning the capsule have been overcome. In passing, it may be noted that Holmgren and Wilander also obtained their highest values for ester sulphates (presumptive heparin content) in ox liver capsule, a tissue which they described as a "pure culture of mast cells'.

TABLE IV

Histamine content ( $\mu \mathrm{g} . \mathrm{g}$. tissue) and the relative mast-cell content of the liver of different species

\begin{tabular}{|c|c|c|c|c|}
\hline \multirow{2}{*}{ Species } & \multicolumn{2}{|c|}{ Capsule } & \multicolumn{2}{|c|}{ Parenchyma } \\
\hline & Histamine & Mast cells & Histamine & Mast cells \\
\hline & 40 & +++ & 5 & + \\
\hline Sheep & 35 & ++ & 6 & + \\
\hline Dog & 24 & ++ & 22 & ++ \\
\hline Cow. & 22 & ++ & 5 & + \\
\hline Pig . & 10 & ++ & 8 & + \\
\hline Cat & 1 & 0 & 1 & 0 \\
\hline
\end{tabular}

It will be noted from Table IV that only dog liver contains much histamine in its parenchyma: this is in line with the rich mast-cell and heparin content of the organ. Examination of the remaining species discloses that, in general, 
there is relatively much more histamine in the capsule of the liver than in the rest of the organ, a paradox hardly to be explained except on the differences in mast-cell content of the two tissues.

This point was again emphasized when lung was examined in the same way. Here it was necessary to remove the 'capsule', the visceral pleura, by the tedious process of sharp dissection. The results show that the histamine content of ox pleura, separated in this way, may actually exceed that of ox liver capsule (Riley, 1953c). This may be due partly to the very thin nature of the pleura and to the larger size of its numerous mast cells (Figs. 9 and 10 and Table V).

TABLE V

Histamine content ( $\mu g . / g$. tissue) and the relative mast-cell content of the lung of different species

\begin{tabular}{|c|c|c|c|c|}
\hline \multirow{2}{*}{ Species } & \multicolumn{2}{|c|}{ Pleura } & \multicolumn{2}{|c|}{ Parenchyma } \\
\hline & Histamine & Mast Cells & Histamine & Mast Cells \\
\hline $\mathrm{Ox}$ & 200 & ++++ & 80 & +++ \\
\hline Sheep & 80 & +++ & 60 & +++ \\
\hline Pig . & 40 & +++ & 20 & ++ \\
\hline Cat. & 38 & ++ & 32 & ++ \\
\hline Dog & 35 & +++ & 20 & ++ \\
\hline Cow. & 25 & ++ & 25 & ++ \\
\hline
\end{tabular}

Interesting as the above findings are in relating the histamine values to the mast-cell contents of various organs and parts of organs in different species, it might perhaps still be argued that the histamine contents are determined by

TABLE VI

Histamine content ( $\mu \mathrm{g} . / \mathrm{g}$. tissue) and the relative mast-cell content of organs of young and adult animals

\begin{tabular}{|c|c|c|c|c|c|}
\hline \multirow{2}{*}{ Organ } & \multirow{2}{*}{ Species } & \multicolumn{2}{|c|}{ Young } & \multicolumn{2}{|c|}{ Adult } \\
\hline & & $\begin{array}{l}\text { Hist- } \\
\text { amine }\end{array}$ & $\begin{array}{l}\text { Mast } \\
\text { Cells }\end{array}$ & $\begin{array}{l}\text { Hist- } \\
\text { amine }\end{array}$ & $\begin{array}{l}\text { Mast } \\
\text { Cells }\end{array}$ \\
\hline Lung . & Cow & 8 & + & 25 & ++ \\
\hline & Man & 6 & + & 25 & ++ \\
\hline & Cat & 4 & + & 36 & ++ \\
\hline Liver capsule & Cow & 5 & + & 22 & $t+$ \\
\hline Liver parenchyma & Cow & 1 & 0 & 5 & + \\
\hline Skin . . . & Cat & 1 & 0 & 20 & ++ \\
\hline
\end{tabular}

some cellular component not specifically demonstrated in the histological preparations. Accordingly comparisons were made between the same tissue at different periods in the life of the organism, taking advantage of the fact that the mast-cell contents of many tissues also vary with the age of the individual. 
It has been known since the time of Ehrlich that, in course of development, mast cells make their appearance late in embryonic life or early in infancy. Comparison was therefore made between the histamine and mast-cell contents of similar organs from foetal or very young mammals and from fully developed adults (Table VI). In every case the low values for histamine in the young organs contrasted with the higher values in adults. Apart from the presence or absence of mast cells, no other obvious histological difference was noted between the pairs of tissues which were examined.

It is therefore concluded from this study of the normal tissues of many species that there does exist a strong positive correlation between the density of the mast-cell population in a tissue and its histamine content. 


\section{HISTAMINE IN TISSUE MAST CELLS: MAST CELLS, HISTAMINE AND HEPARIN IN PATHOLOGICAL CONDITIONS}

$\mathrm{I}$

$\mathrm{N}$ view of the apparently close association between the mast cells and histamine in normal tissues, it seemed desirable next to examine certain pathological tissues in which the mast cells are increased in number. Two such conditions are known: urticaria pigmentosa in man, and mast-cell tumours in domestic animals. Both conditions are rare.

\section{Urticaria pigmentosa}

Urticaria pigmentosa was first described clinically by Nettleship in 1869 (the French still retain the term 'maladie de Nettleship') and later by Thin (1877). Typically it occurs in infants in whom, after periods of exacerbation and remission, the condition usually clears up spontaneously. Two types of urticaria pigmentosa are described: the common one is a generalized rash of copper-coloured spots which when traumatized undergo 'urtication', that is, they resemble the stings of the common nettle, 'urtica urens'. In the other type, which is distinctly rare, the disease shows itself as a solitary lesion, often of considerable size. The pathological basis of both types of lesion is a smaller or greater aggregation of tissue mast cells under a thin epidermis, the basal cells of which are pigmented (Unna, 1896).

Thanks to the kindness of my former co-worker, Dr. J. M. Drennan, four weighed biopsy specimens in trichloracetic acid were obtained from children with urticaria pigmentosa: two were from cases of the common, generalized type and two from larger solitary lesions. The histological findings in these cases have been described in detail (Drennan, 1951; Drennan and Beare, 1954). More recently a further specimen from a case of 'bullous' urticaria pigmentosa (i.e. with lesions progressing to blister formation on trauma) has been obtained from Dr. Girdwood-Ferguson, Glasgow, and another example of the more typical generalized type, arising in an adult patient, from Dr. J. C. Ford, Birmingham (Figs. 24-26).

So far as the mast-cell content of these specimens is concerned, it suffices to note that in the first of the two solitary lesions the mast cells extended so deeply as to occupy the entire thickness of the biopsy specimen; in the second the mast cells petered out about half way down the tissue block: in contrast, the mast cells were disposed in only a thin layer under the epidermis in the biopsy specimens from the cases with generalized urticaria pigmentosa. By way of controls, histamine was estimated in a sample of skin immediately adjacent 


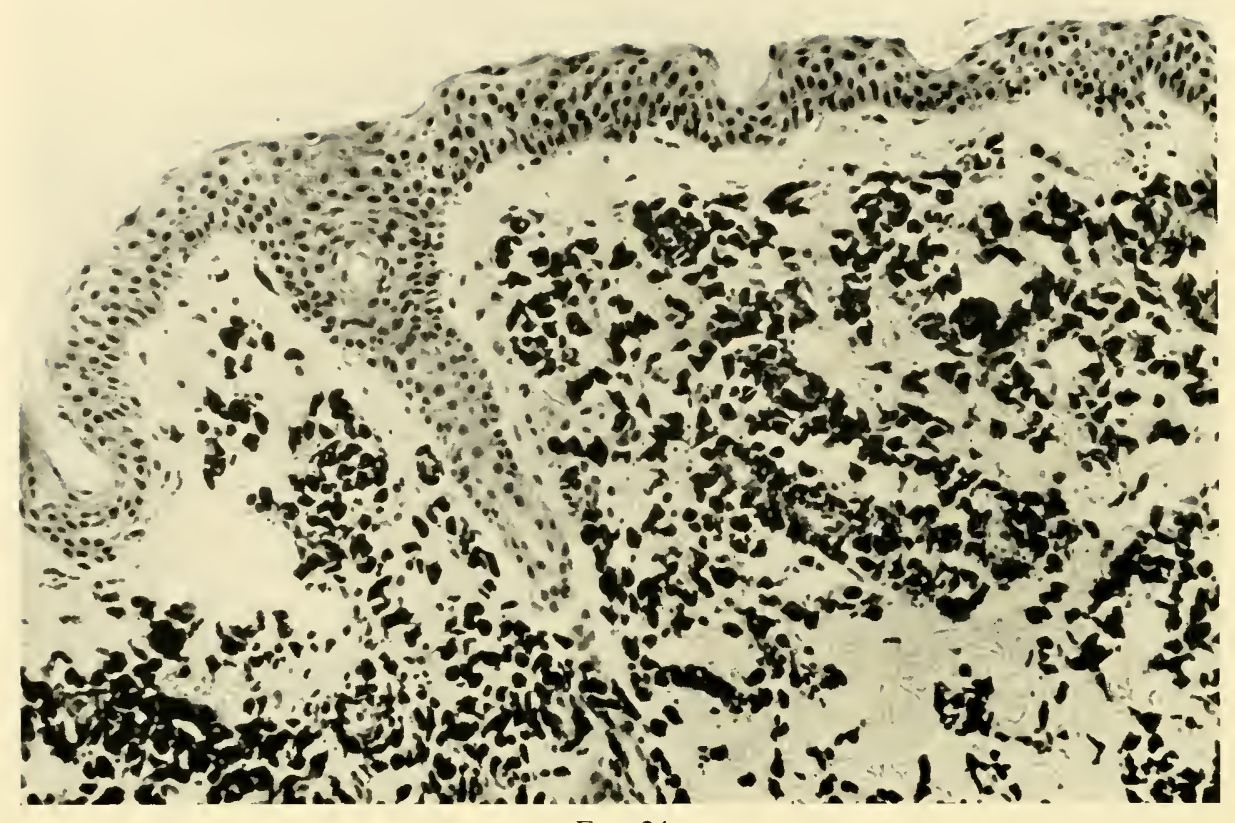

FIG, 24

Urticaria pigmentosa. Skin biopsy section from a case of generalized urticaria pigmentosa, stained Nile blue followed by toluidine blue. Masses of angular mast cells lie in the corium $(\times 184)$.

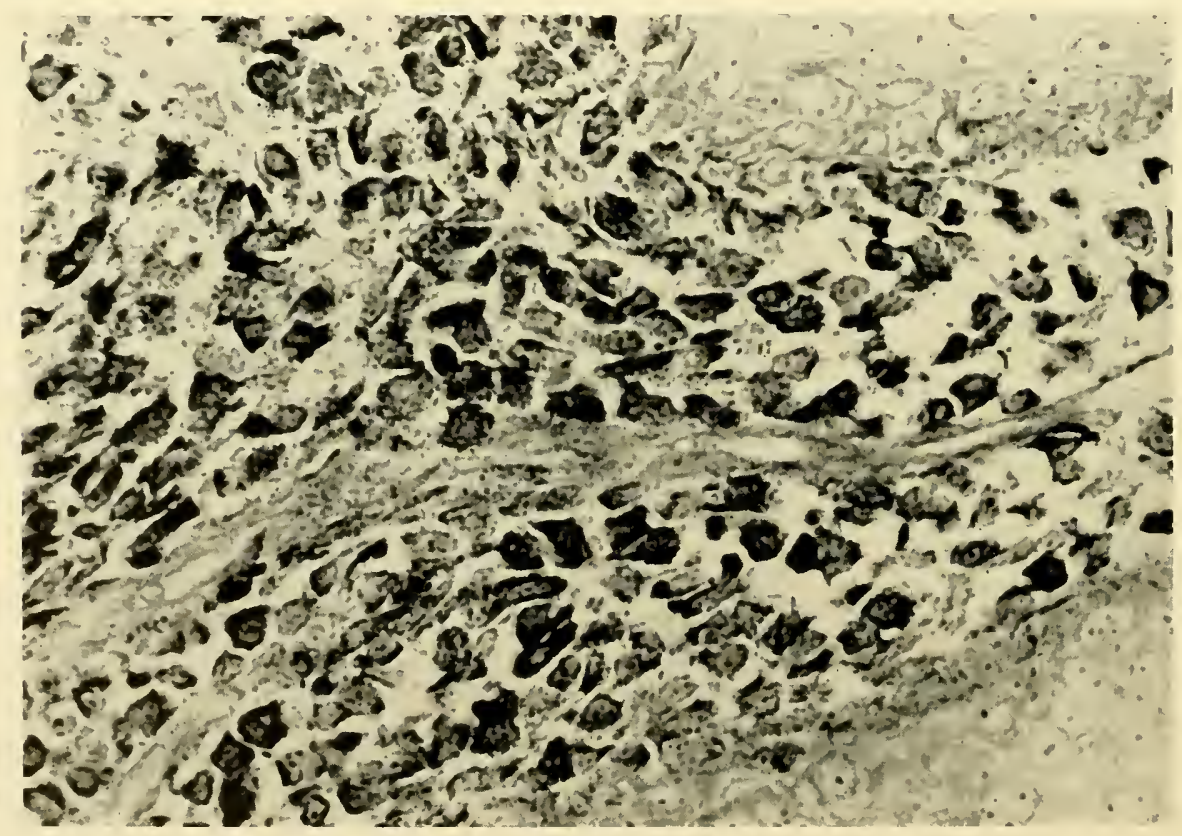

FIG. 25

Urticaria pigmentosa. another case. Under higher magnification the dermal papilla is seen to be filled with well-granulated mast cells. Here the photograph is mounted on its side, epidermis to the right. Eosin toluidine blue $(\times 360)$. 
HISTAMINE：PATHOLOGICAL TISSUES

to an active lesion of the generalized type and in a series of samples of normal skin obtained from patients undergoing operations to breast or abdomen. These normal values agree closely with the figures published by Nilzén (1947)The results of the present investigation are set out in Table VII.

TABLE VII

Mast cells and histamine in normal human skin and in skin lesions of urticaria pigmentosa of varying extent

\begin{tabular}{|c|c|c|c|}
\hline Case No. & Type of lesion & $\begin{array}{l}\text { Histamine } \\
\text { content } \\
\text { ( } \mu \mathrm{g} . / \mathrm{g} .)\end{array}$ & Mast-cell content of specimen \\
\hline 1 & Solitary & 950 & $\begin{array}{l}\text { Whole thickness occupied by } \\
\text { mast cells }\end{array}$ \\
\hline 2 & Solitary & 555 & $\begin{array}{l}\text { Approximately half thickness } \\
\text { occupied by mast cells }\end{array}$ \\
\hline 3 & Generalized (active) & $50 \cdot 0$ & $\begin{array}{l}\text { Thin layer of mast cells under } \\
\text { epidermis }\end{array}$ \\
\hline 4 & $\begin{array}{l}\text { Generalized } \\
\quad \text { (quiescent) }\end{array}$ & $35 \cdot 0$ & $, \quad, \quad, \quad, \quad$, \\
\hline 5 & $\begin{array}{l}\text { Generalized } \\
\text { ('bullous ') }\end{array}$ & $56 \cdot 4$ & $"$ \\
\hline 6 & $\begin{array}{l}\text { Generalized } \\
\text { (adult type) }\end{array}$ & $39 \cdot 0$ & " $\quad, \quad \quad$, \\
\hline 7 & $\begin{array}{l}\text { Skin adjacent to } \\
\text { active lesion (same } \\
\text { patient as No. 3) }\end{array}$ & $20 \cdot 0$ & Many scattered mast cells \\
\hline $8-17$ & $\begin{array}{l}\text { Specimens of normal } \\
\text { skin }\end{array}$ & $5-10$ & Few scattered mast cells in each \\
\hline
\end{tabular}

The above results thus strongly support the view that the histamine value in human skin varies directly with its mast-cell content.

\section{Mast-cell tumours from domestic animals}

Dogs (See: Cass et al, 1954). A subcutaneous tumour-like collection of mast cells, so-called mastocytoma, has for long been recognized as a rare condition which occurs almost exclusively in dogs (Murray, 1908; Bloom, 1942) though solitary examples have been reported in a horse (Sabrazès and Lafon, 1907), a cat (Sabrazès, Muratet and Antoine, 1908) and a cow (Greig, 1950). Oliver, Bloom and Mangieri (1947) used such a tumour from a dog to prove that a powerful anticoagulant (heparin) can be extracted from the mast cell. We, in turn, have employed mastocytomas from dogs, cats and cattle to show that not only does the mast cell contain heparin; it is also extraordinarily rich in histamine.

However, various difficulties were found to lie in the way of implementing this programme of estimating histamine in mast-cell tumours from animals, though once the necessary channels for obtaining material had been established 


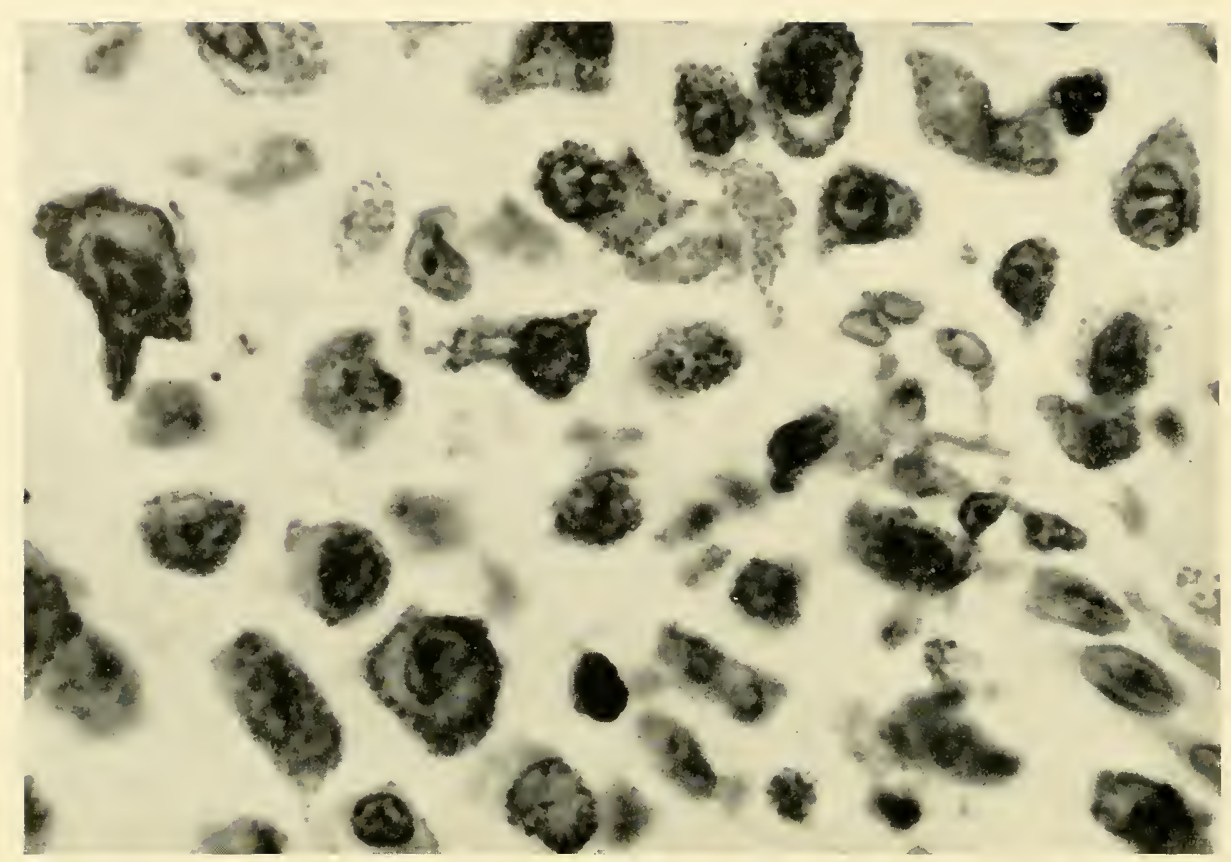

Fig. 26

Mast cells in all stages of development are present in this section of solitary urticaria pigmentosa; cytoplasmic granules are clearly visible. Many cells also show a juxta-nuclear clear zone, indicative of the cell's immaturity. Toluidine blue $(\times 800)$.

Courtesy Dr. J. M. Drennan.

the results led us to suspect that mast-cell tumours are perhaps not quite so rare as was formerly supposed (Nielsen, 1952; Head, 1953, 1958).

Contact was first made with a number of veterinary surgeons in Scotland and England. To those who agreed to co-operate, pairs of bottles were sent containing respectively $(a)$ a measured volume of 10 per cent trichloracetic acid for a fresh, weighed sample of tissue for histamine assay, and $(b)$ formolcorrosive fixative for a small piece of tissue for histological confirmation of the diagnosis. Despite our efforts, nearly two years elapsed before the first mast-cell tumour was obtained.

Three factors appear to have contributed to this initial failure to obtain suitable material in addition to the acknowledged rarity of the tumours. The first is that many of the specimens which are examined at veterinary centres are submitted by outside practitioners: the tissue is often unfixed and there may be considerable delay in transit. Secondly, by the time that a routine pathological examination has been made and a diagnosis established, a further 7-10 days may have elapsed, by which time the gross specimen (even if retained) is now useless for histamine assay. Thirdly, a histological diagnosis of mast-cell 


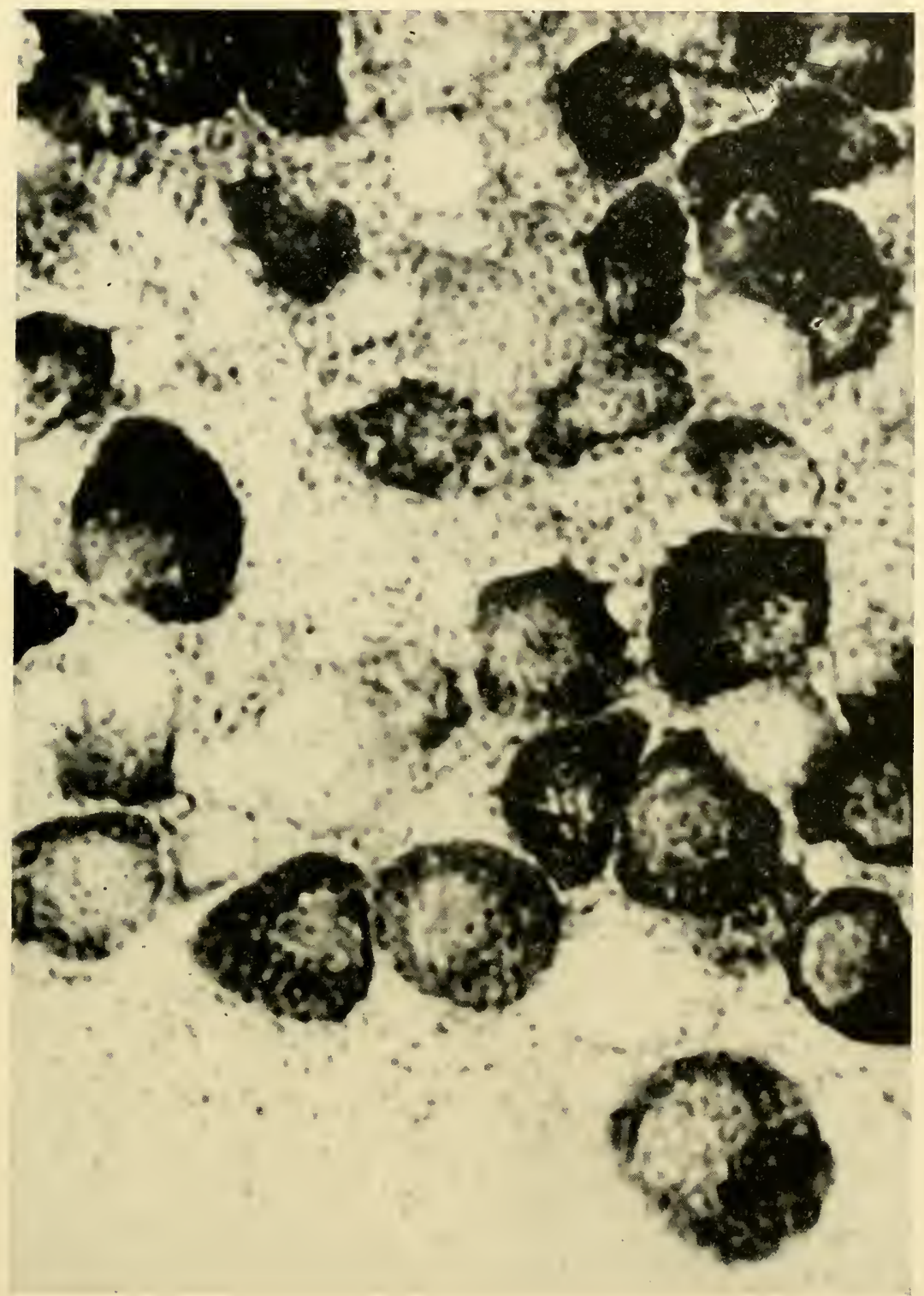

FIG. 27

Rapid diagnosis of a mast-cell lesion. An imprint is made on a slide and is stained at once, as a blood film. This preparation was made by Mr. K. W. Head following the local excision of a mastocytoma in a dog. Leishman-Giemsa $(\times 1,500)$. (Photograph by Mr. R. C. James.) 
tumour will be missed if only the standard haematoxylin-eosin routine is used since the mast granules fail to stain by this method. This must have happened often in the past. However, as Nielsen (1952) emphasizes, an immediate diagnosis can be reached by making an imprint of a fresh slice of tumour on a microscope slide and staining this, as a blood film, either with the Giemsa stain or merely with a drop of $0 \cdot 1$ per cent toluidine blue. This

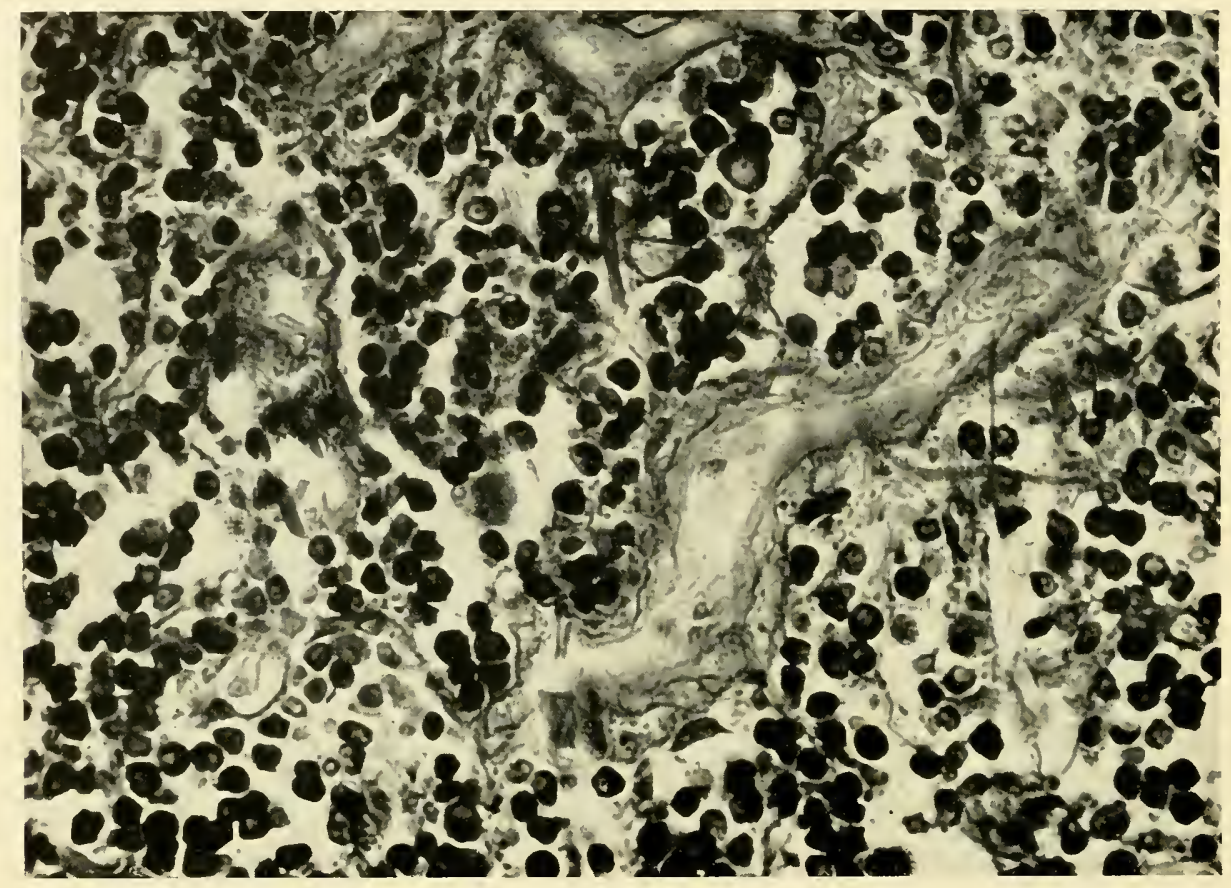

FIG. 28

Paraffin section of dog mastocytoma. Rounded densely-staining mast cells set in a coarse collagenous stroma. Toluidine blue $(\times 416)$.

simple method of screening tumours in veterinary practice would no doubt disclose many mast-cell tumours which would otherwise be overlooked (Fig. 27).

Results. The first dog mastocytoma was sent to us in August 1952 by $\mathrm{Mr}$. E. Cotchin, M.R.C.V.S., of the Royal Veterinary College and Hospital, London, the specimen being part of a tumour from the right axilla of a five-year-old female Boxer dog. The tumour had been excised by an outside practitioner, and there was some delay before a weighed portion of tissue was placed in one of our containers of trichloracetic acid pending further laboratory examination. Histologically the tumour was found to consist of a coarse collagenous framework enclosing islands of cells which stained deeply and metachromatically with toluidine blue and with the Giemsa method, though individual cytoplasmic 
granules could seldom be distinguished (Fig. 28). Its histamine content was $295 \mu \mathrm{g} . \mathrm{g}$.

The second dog mastocytoma arrived barely a month later from Mr. K. W. Head, M.R.C.V.S., of the Royal (Dick) School of Veterinary Studies, Edinburgh. This specimen was part of a recurrent tumour from the right hip region of a nine-year-old male Irish Setter. A diagnosis of 'mast-cell sarcoma' was made from frozen sections cut and stained within twelve hours of operation. Thereupon a weighed portion of the original specimen was placed in trichloracetic acid. Histologically the tumour contained many cells with granules which stained metachromatically with toluidine blue and brilliantly with Gomori's aldehyde-fuchsin method. Its histamine content was $109 \mu \mathrm{g} . / \mathrm{g}$. Encouraged by these findings we approached Messrs. Boots, Nottingham, for advice regarding methods for the extraction and assay of heparin in tissues. Following discussions with Mr. S. W. Stroud of their research department, it was agreed that the actual assays should be carried out at Nottingham. At the suggestion of Mr. Stroud we therefore sent bottles of chloroform water to each of the previous recipients with the request that they include a second weighed sample of tissue for heparin assay. This was fortunate since the next tumour, obtained locally in Dundee, proved to be a classic case both from the standpoint of histamine and of heparin in mast cells.

'Judy', a ten-year-old female Golden Cocker Spaniel, was first seen by the veterinary surgeon, Dr. J. Spreull, in November 1953, on account of a swelling on the right flank which had been present for a little over a month. The tumour was removed under anaesthesia and sent to Edinburgh for diagnosis. On learning from Mr. K. W. Head that a mast-cell tumour had been located in Dundee, I approached Dr. Spreull and requested him to let me know if there should be any sign of recurrence or metastasis.

Early in January 1954 the dog was brought back with a $3 \times 2 \mathrm{~cm}$. lobulated swelling under the skin immediately anterior to the previous excision scar. This lesion was widely excised under intravenous pentobarbitone sodium anaesthesia and was found to consist of a soft vascular tumour lying in a grossly oedematous subcutis. There was no excessive or prolonged bleeding during the operation and the wound later healed rapidly and without the formation of a haematoma: in other words there was nothing to suggest clinically the presence of a powerful anticoagulant in the wound area, although a prolonged clotting time has been recorded in another series of cases of this type (Bloom et $a l, 1958 b)$. Fresh weighed samples of tissue were taken for histamine and heparin assay, and several minute slices were removed aseptically from the centre of the tumour and placed in Tyrode's fluid for an attempt at culture of mast cells in vitro by Dr. J. D. B. MacDougall of the Department of Anatomy. This was successful, and the results have been published (MacDougall and 


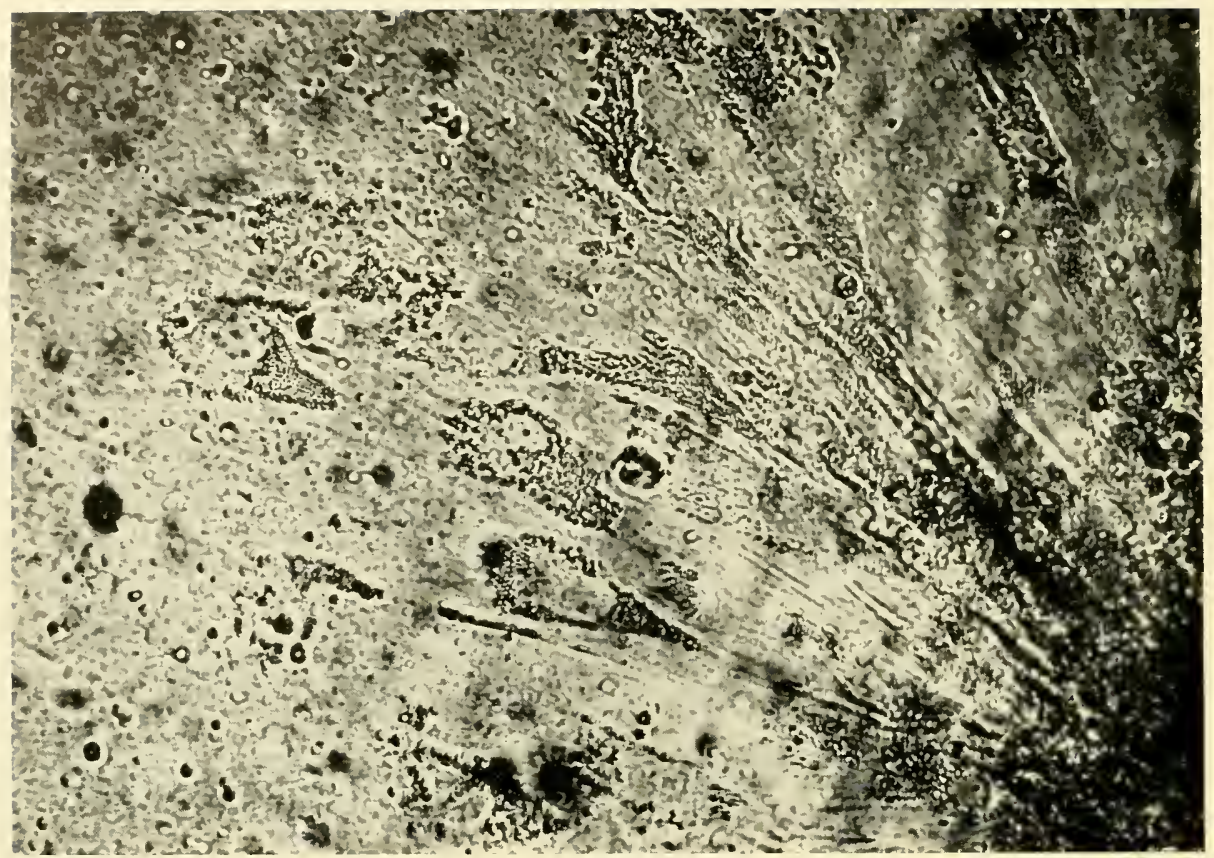

FIG. 29

Mast cells in tissue culture. Well-granulated mast cells are creeping out from the primary explant, a fragment of dog mastocytoma (bottom R.). Phase contrast photograph, Dr. J. B. MacDougall $(\times 372)$.

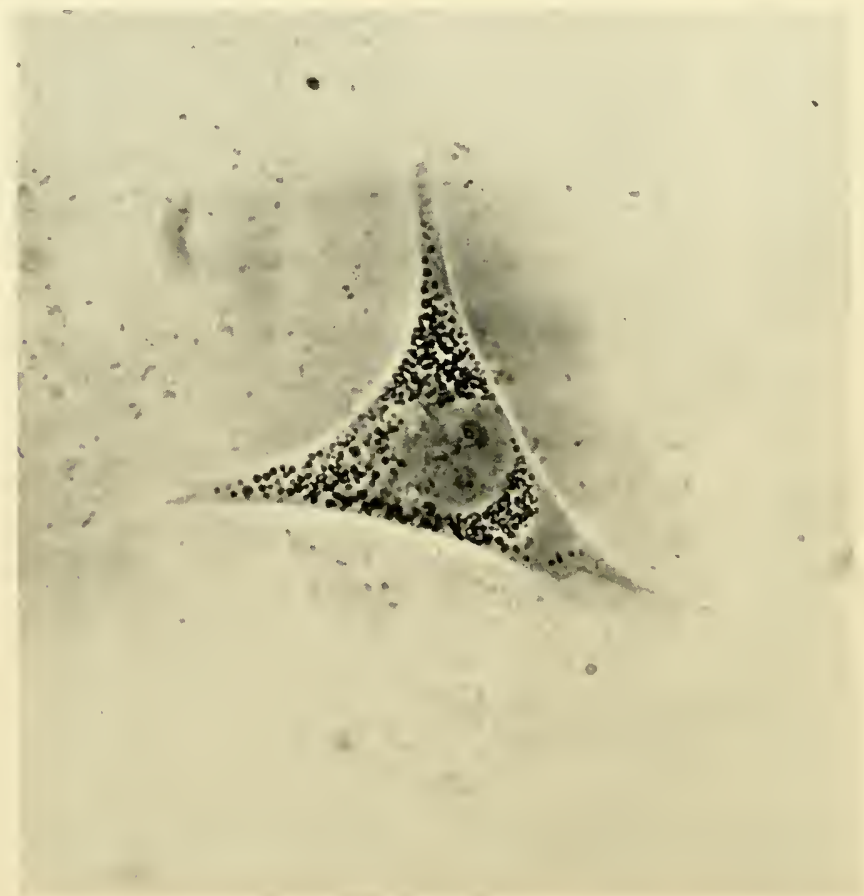

FIG. 30

Isolated mast cell from a primary explant of dog mastocytoma grown for six days in tissue culture. Phase contrast photograph, Dr. J. B. MacDougall $(\times 640)$. 
Riley, 1954; MacDougall, 1954; Figs. 29, 30). Histologically the tumour proved to be a recurrence of the cellular mastocytoma previously diagnosed in Edinburgh. Its histamine content was no less than 1,290 $\mathrm{g}$. /g. - the highest we have recorded in such a lesion. Heparin was extracted by Mr. Stroud, using a modification of the original method of Charles and Scott (1933), and assayed against a standard solution of heparin on whole blood. Clean ox liver capsule, which has the highest heparin content of all normal tissues, yields up to 50 i.u.'g. The heparin content of the present tumour was 110 i.u./g.

Nor does the story end there. Two months later the dog was again brought to the veterinary surgeon with further signs of local recurrence and with now a request that the animal be destroyed. Accordingly 'Judy' was given a lethal

TABLE VIII

Histamine content ( $\mu \mathrm{g} . \mathrm{g}$.$) of tissues compared with heparin$ content (i.u.g.) and relative mast-cell content in a 10 y.o. Golden Cocker Spaniel with a mast-cell tumour and metastases. (Figures in brackets represent average control values from 4 normal dogs)

\begin{tabular}{|c|c|c|c|}
\hline Tissue & Histamine & Heparin & Mast Cells \\
\hline $\begin{array}{l}\text { Tumour } \\
\text { (1st recurrence) }\end{array}$ & 1,290 & 110 & ++++ \\
\hline $\begin{array}{l}\text { Tumour } \\
\text { (2nd recurrence) }\end{array}$ & 650 & 357 & ++++ \\
\hline Lymph node & 600 & $293 \quad(9)$ & ++++ \\
\hline Spleen $\quad$. & $90 \quad(5)$ & 88 (7) & +++ \\
\hline Liver . & $60(25)$ & $50(20)$ & ++ \\
\hline Lung . & $30(25)$ & 29 (I3) & ++ \\
\hline Skin . & $10(9)$ & $8(11)$ & + \\
\hline Kidney & 1 (1) & $5(6)$ & 0 \\
\hline
\end{tabular}

intravenous dose of pentobarbitone sodium followed by the intracardiac injection of potassium cyanide. Post-mortem examination was carried out at once.

At autopsy enlarged lymph nodes were found in the axilla of the same side as the tumour; the liver had a slightly granular appearance and the spleen was enlarged. These and other organs were taken for microscopic examination and for estimation of their histamine and heparin contents. The results are set out in Table VIII; the figures in parenthesis are the average histamine and heparin values for the corresponding organs from four healthy dogs. It will be observed that although the histamine value of the recurrent tumour is somewhat lower than before, its heparin value is now even higher and is the highest recorded value for such lesions.

The data from this case indicate beyond doubt that the factor which determines the histamine and heparin values in the tissues of the dog is the extent 
THE MAST CELLS

TABLE IX

Histamine and heparin values in ten further cases of mastocvtoma in dogs

\begin{tabular}{|c|c|c|c|c|c|c|c|c|}
\hline $\begin{array}{l}\text { Case } \\
\text { No. }\end{array}$ & Breed & Age & Sex & Site & $\begin{array}{l}\text { Delay } \\
\text { (hrs.) }\end{array}$ & Duration & $\begin{array}{l}\text { Hist- } \\
\text { amine }\end{array}$ & Heparin \\
\hline 1 & Terrier & 10 & $M$ & Flank & 12 & 6 weeks & 765 & $61 \cdot 2$ \\
\hline II & Terrier & 7 & M & Perianal & 0 & 6 months & 500 & $147 \cdot 2$ \\
\hline 111 & Golden Labrador & 10 & $\mathrm{~F}$ & Leg & 50 & (unknown) & $7 \cdot 3 *$ & 130.0 \\
\hline IV & Scottie & 7 & $\mathrm{~F}$ & Leg & $\begin{array}{l}3 \\
0\end{array}$ & $\begin{array}{l}3 \text { months } \\
2 \text { months }\end{array}$ & $\begin{array}{l}520 \\
277\end{array}$ & $\begin{array}{l}21 \cdot 4 \\
21 \cdot 0\end{array}$ \\
\hline V & Black Labrador & 12 & $M$ & Thigh & 48 & 2 years & 550 & $174 \cdot 0$ \\
\hline VI & Bull Terrier & Old & $\mathrm{M}$ & Groin & 36 & $\begin{array}{l}1 \text { month } \\
\text { (recurrence) }\end{array}$ & 212 & $(\text { N.A. })^{* *}$ \\
\hline VII & Staffs. Bull Terrier & 12 & $\mathrm{M}$ & Thigh & 24 & $?$ & 179 & 211 \\
\hline VIII & Terrier Cross & 6 & $\mathrm{~F}$ & Neck & $\begin{array}{l}48 \\
24\end{array}$ & $\begin{array}{l}3 \text { months } \\
2 \text { months }\end{array}$ & $\begin{array}{l}661 \\
629\end{array}$ & $\begin{array}{l}434 \\
590\end{array}$ \\
\hline IX & Bull Mastiff & Old & M & Perineum & 120 & $\begin{array}{l}\text { (recurrence) } \\
\text { (renth }\end{array}$ & 219 & 368 \\
\hline$x$ & Staffs. Bull Terrier & 8 & M & Perineum & 1 & $\begin{array}{l}6 \text { months } \\
\text { (third } \\
\text { recurrence) }\end{array}$ & 203 & $28 \cdot 6$ \\
\hline
\end{tabular}

* This small tumour was sent wrapped in a formalin swab; the histamine content falls rapidly in such conditions.

** N.A. (not available): the container was accidentally broken in the post.

TABLE $X$

Histamine and heparin values for various tissues obtained post-mortem from 5 dogs with mast-cell tumours (numbered as in Table IX) compared with normal controls

\begin{tabular}{|c|c|c|c|c|c|c|c|c|c|c|c|c|}
\hline \multirow[t]{2}{*}{ Tissue } & \multicolumn{2}{|c|}{$\begin{array}{c}\text { IV } \\
\text { (7 y.o. } \\
\text { Scottie) }\end{array}$} & \multicolumn{2}{|c|}{$\begin{array}{c}\text { VI } \\
\text { (Old Bull } \\
\text { Terrier) }\end{array}$} & \multicolumn{2}{|c|}{$\begin{array}{c}\text { VIl } \\
\text { (12 y.o. } \\
\text { Staffs. } \\
\text { Bull Terrier) }\end{array}$} & \multicolumn{2}{|c|}{$\begin{array}{l}\text { V111 } \\
\text { (6 y.o. } \\
\text { Terrier } \\
\text { Cross) }\end{array}$} & \multicolumn{2}{|c|}{$\begin{array}{c}\text { IX } \\
\text { (Old Bull } \\
\text { Mastiff) }\end{array}$} & \multicolumn{2}{|c|}{$\begin{array}{l}\text { Controls } \\
\text { (4 normal } \\
\text { dogs) }\end{array}$} \\
\hline & Hist. & Hep. & Hist. & Hep. & Hist. & Hep. & Hist. & Hep. & Hist. & Hep. & Hist. & Hep. \\
\hline $\begin{array}{l}\text { Tumour- } \\
\text { primary }\end{array}$ & 520 & $21 \cdot 4$ & - & - & 179 & 211 & 661 & 434 & - & - & - & - \\
\hline $\begin{array}{l}\text { Tumour } \\
\text { recurrence } \\
\text { Lymph }\end{array}$ & 277 & $21 \cdot 0$ & 212 & - & 210 & - & 629 & 590 & 219 & 368 & - & - \\
\hline node & 139 & 24 & 168 & - & - & - & 882 & - & - & - & 4 & 9 \\
\hline Lung & 24 & 19 & 11 & - & 16 & - & 140 & 62 & - & - & 25 & 13 \\
\hline Liver & 22 & $21 \cdot 3$ & 11 & - & 80 & - & 40 & 40 & 24 & 34 & 25 & 20 \\
\hline Spleen & $5 \cdot 5$ & 5 & 2 & - & 21 & - & 194 & 312 & 5 & $7 \cdot 7$ & 5 & 7 \\
\hline Skin & 8 & 8 & $21^{*}$ & - & - & - & - & - & $44^{*}$ & $34^{*}$ & 9 & 11 \\
\hline Kidney & $0 \cdot 6$ & 9 & $0 \cdot 2$ & - & - & - & - & - & $0 \cdot 3$ & 4 & 1 & 6 \\
\hline
\end{tabular}

(* Skin adjacent to tumour) 
to which they contain mast cells. Thus, the enlarged lymph node was virtually replaced by mast cells; many mast cells were present in the enlarged spleen and there was some increase in mast cells in the portal tracts of the liver. On the other hand, very little increase in mast-cell content was found in the lung, and none in kidney or in skin taken from the flank remote from the primary growth.

Thanks to the continued co-operation of Mr. K. W. Head, ten further specimens from dogs with mast-cell tumours have been obtained for study. All support the conclusions previously reached, that the mast cell in the dog is as rich in histamine as it is rich in heparin (Table IX, p. 86). It is of interest to record in passing that portions of two other subcutaneous tumours from dogs which were sent to us pending histological diagnosis were found to have very low histamine values (only $2 \cdot 1$ and $1 \cdot 1 \mu \mathrm{g}$. $\mathrm{g}$. tissue respectively) and to contain no detectable heparin: the first proved to be a fibroma, the second a squamous carcinoma. This further confirms the view that it is the mast cell which contains both the heparin and the histamine.

Of the ten dogs with mastocytoma recorded in Table IX no less than five had ultimately to be destroyed either on account of local recurrence or distant metastases. The findings are recorded in Table X (p. 86).

Examination of Tables VIII-X (pages 85-86) clearly indicates that so far as the dog is concerned, a raised mast-cell content in a tissue is invariably accompanied by a parallel increase in both tissue histamine and tissue heparin.

CATS. Mast-cell tumours in cats are decidedly less common than mast-cell tumours in dogs. In their original description of a mast-cell tumour in a cat, Sabrazès and co-workers (1908) recorded a case in which a pigmented tumour was situated on the eyelid and was thought to be a melanoma. However, at autopsy the spleen was found to be enlarged and studded with masses of mast cells which appeared to be arising from large mononuclear cells surrounding the lymphoid follicles. We have been fortunate in obtaining material from three mast-cell lesions in cats, the first of which almost exactly duplicates the original case described by the French workers.

A nine-year-old female castrated cat had to be destroyed on account of a tumour which had been present on its lower eyelid for about three months. Post-mortem examination was carried out five hours after death. A weighed portion of the tumour was sent to us in trichloracetic acid and another portion placed in chloroform water for heparin assay. At autopsy it was also observed that there was enlargement of some of the retropharyngeal and submaxillary lymph nodes and of the spleen. Biopsy specimens for histological examination were taken from these various organs and from the liver, although, unfortunately, no material other than the primary tumour was reserved for histamine or heparin assay. Histologically the tumour was found to consist almost entirely of 
well-granulated mast cells which stained brilliantly with the Leishman-Giemsa and aldehyde-fuchsin methods. The granules also stained positively with the periodic acid-Schiff method, indicating perhaps that here the heparin is not fully sulphated (Jorpes, Werner and Aberg, 1948). Mast cells were numerous in the enlarged nodes and spleen and were present as islets of cells in the liver parenchyma and as extensions along the portal tracts. The histamine content of the primary tumour was very high indeed $-1,250 \mu \mathrm{g}$. g. Curiously enough, the heparin content (measured as anticoagulant) was low-only $8.0 \mathrm{i} . \mathrm{u} . / \mathrm{g}$.

The second case was that of a five-year-old female cat with numerous small skin nodules, some of which had undergone ulceration. The condition had been present for two months and had failed to respond to a course of streptomycin. Accordingly, three nodules were removed, one for histological examination and the others for pharmacological assay, though two days elapsed before they were placed in the appropriate fluids. The skin nodule proved to be a non-encapsulated aggregation of mast cells in the upper dermis: its histamine content (after two days) being $32 \mu \mathrm{g}$. g. Again the heparin value was low, only 6.5 i.u. g. Later the animal was destroyed and the carcass sent for post-mortem examination, though there was again an inevitable delay of two days in transit, the specimen having been sent from a veterinary practitioner in Lancashire. At autopsy it was found that many of the lymph nodes draining the skin were enlarged and that there was gross enlargement of the spleen. The abdominal lymph nodes and bone marrow appeared normal. Microscopically it was found that here, as in the first case, the nodes draining the involved skin were infiltrated with well-granulated, metachromatic mast cells and that in the skin itself the nodules were very numerous indeed. The spleen was very heavily infiltrated and there was widespread periportal infiltration of mast cells in the liver. In contrast, the lung contained only a few additional mast cells: kidney and bone marrow were normal. The histamine and heparin values of various tissues in this case and the extent to which they diverge from normal values are set out in Table XI.

\section{TABLE XI}

Histamine and heparin values in tissues obtained two day's postmortem from a cat with multiple mast-cell nodules in the skin. (Figures in brackets indicate relationship to normal values)

\begin{tabular}{|c|c|c|c|}
\hline & & Histamine ( $\mu \mathrm{g} . / \mathrm{g})$. & Heparin (i.u./g.) \\
\hline Skin nodules & & $75(\times 8)$ & $(\times 1 \cdot 5)$ \\
\hline Lymph node & & $16(\times 4)$ & $(\times 2)$ \\
\hline Spleen & & $150 \quad(\times 30)$ & $(\times 2)$ \\
\hline Liver. & & $71(\times 3)$ & $(\times 1 \cdot 5)$ \\
\hline Lung. & & $59 \quad(\times 2)$ & $(\times 1)$ \\
\hline Kidney & . & $0.6(\times 1)$ & $(\times 1)$ \\
\hline
\end{tabular}


The third example of a mast-cell tumour in a cat occurred in a three-year-old castrated male which developed numerous skin nodules over a period of about two months. At post-mortem examination it was also discovered that some of the lymph nodes draining the skin were enlarged and that there was considerable enlargement of the spleen, as in the two previous cases. Material for histamine assay was placed in trichloracetic acid within two hours of death. No tissue was obtained for heparin estimation. The histamine values are shown in Table XII. Histological examination of corresponding material confirmed the very close parallelism between the mast-cell contents of the various tissues on the one hand and the histamine values on the other. Here, as in the dog, it will be noted that the spleen was the chief site of secondary involvement in all three cases of mastocytoma in cats.

\section{TABLE XII}

Histamine values in tissues obtained two hours post-mortem from a three-year-old male cat with multiple mastocytomas of the skin

\begin{tabular}{|c|c|}
\hline & Histamine $(\mu \mathrm{g} . \mathrm{g})$. \\
\hline Skin nodule & 80 \\
\hline Lymph node & 285 \\
\hline Spleen & 1,230 \\
\hline Liver. & 56 \\
\hline
\end{tabular}

CATTLE. Having assayed histamine and heparin in urticaria pigmentosa in man, and in mastocytomas from dogs and cats, we were exceedingly fortunate in being able also to examine repeatedly material from a cow with multiple mastocytomas of the skin (Head et al, 1953; 1958). Such tumours are very rare indeed (Head, 1953).

In the autumn of 1954 a six-months'-old shorthorn heifer developed multiple small skin nodules which bled easily on slight trauma, though there was no impairment of general condition. A biopsy specimen sent from Leeds to Edinburgh and examined by Mr. K. W. Head was diagnosed as a mast-cell tumour and, accordingly, bcttles of the appropriate fluids for histamine and heparin assay were forwarded to the practitioner who kindly removed and weighed further nodules for which the following values were obtained: histamine $180 \mu \mathrm{g} . / \mathrm{g}$., heparin $14 \mathrm{i} . \mathrm{u} . / \mathrm{g}$. Through the good offices of the Royal (Dick) School of Veterinary Studies, the cow (now in calf) was purchased and brought to Edinburgh where it gave birth to a normal bull calf in May 1955.

During pregnancy the animal remained in excellent condition, developed the usual long winter coat (except immediately around the nodules) and shed this coat normally in the spring. Meanwhile, no fresh nodules had appeared and the ulceration in many of the existing nodules had subsided. It will be 
observed from Table XIII that the histamine values of biopsy specimens taken at intervals during pregnancy also declined, only to rise again after the birth of the calf. This immediately brings to mind the striking rise in activity of the enzyme, histaminase, in the blood of women during pregnancy. However, no comparable fluctuation is believed to take place in the blood histaminase of cattle (Kolb, 1956). Presumably, therefore, either the association here is fortuitous or some other factor in pregnancy is responsible. It is hoped that material may become available during another pregnancy and so clarify the situation. Histological examination at each stage showed good correspondence with the results of the pharmacological assays, the majority of the mast cells becoming less well granulated as pregnancy progressed.

TABLE XIII

Histamine and heparin valnes in multiple mast-cell tumours in a cow. Note the fall in the histamine content during pregnancy. $[C=$ calved $]$

\begin{tabular}{|c|c|c|c|c|c|c|}
\hline Date & $\begin{array}{c}\text { Oct. } \\
1954\end{array}$ & $\begin{array}{c}\text { Nov. } \\
1954\end{array}$ & $\begin{array}{c}\text { Dec. } \\
1954\end{array}$ & $\begin{array}{c}\text { Feb. } \\
1955\end{array}$ & $\begin{array}{c}\text { May } \\
1955 \mathrm{C}\end{array}$ & $\begin{array}{c}\text { Dec. } \\
1955\end{array}$ \\
\cline { 1 - 5 } & 180 & 160 & 108 & 15 & 23 & 193 \\
\hline $\begin{array}{c}\text { Histamine } \\
\text { (ug./g.) } \\
\text { Heparin } \\
\text { (i.u. g.) }\end{array}$ & 14 & 24 & - & - & - & - \\
\hline
\end{tabular}

Other investigations on this case included cytological blood examination, tissue culture and the attempted autotransplantation of tumour material. Briefly the results were as follows. No changes were detected either in the cellular composition of the blood or in its clotting time throughout the period of observation; indeed, only three blood basophils were encountered among the 1,400 white cells which were examined.

Dr. J. D. B. MacDougall who had previously explanted material from a dog tumour also succeeded in growing bovine mast cells in tissue culture from a fragment of a biopsy specimen taken in December 1954 and reported his findings at the International Congress of Anatomy in Paris in July 1955. However, no growth followed the immediate re-implantation at other sites of biopsy material removed in February 1955, at which time the histamine value was at its minimum. It is hoped to repeat this experiment in autotransplantation at a later date.

Mice. The first transplantable mast-cell tumour to be discovered (p. 26) was the so-called ' 3187 mast-cell sarcoma' which arose in a mouse undergoing repeated skin painting with coal tar. Unfortunately this tumour had died out some years before I became interested in the histamine content of tissue mast cells. 
Recently, however, two fresh mast-cell tumours in mice have been described. The first (Dunn and Potter, 1957) has already been shown to be rich in histamine (Sjoerdsma et al, 1957); the second, of which we were fortunate enough to obtain an example, has been similarly investigated by Furth and his group (Furth et al, 1957). In our hands (Cass et al, 1958), lyophilized samples of tumour yielded no less than $1700 \mu \mathrm{g}$. g. histamine and $944 \mathrm{i.u}$. g. heparin. The mouse mastocytomas are unique in that they also contain substantial amounts of a second amine, 5-hydroxytryptamine.

\section{DisCUSSION}

The significance of the earlier finding of a striking positive correlation between the mast-cell and histamine contents of normal tissues is greatly strengthened by the examination of pathological material abnormally rich in mast cells. Urticaria pigmentosa in man, mast-cell tumours in dogs, cats, cattle and mice, all demonstrate conclusively that an excessively high mast-cell content in a tissue is associated with a correspondingly high histamine value. In the case of the tumours, histamine assay of an organ proved to be as accurate a method as histological examination for the detection of distant metastases.

Curiously enough, it is now the heparin which, in certain species, shows the poorer correlation with the mast-cell content. Whereas in dogs, the heparin values are in general proportionate to the mast-cell content, the cat tumours yielded surprisingly low values for heparin, despite the brilliant metachromatism of the granules in tissue sections. This heightens the suspicion raised in the Introduction that the estimation of heparin as an anticoagulant, may not truly reflect the function of heparin in the organism. It would be of interest to confirm the low potency of cat heparin on plasma of the same species.

The pattern of spread and metastasis in all the above conditions is of interest. The majority of the cases with localized tumours showed spread to the regional lymph nodes: this supports the theory of a focal origin of the tumour. However, in others there was involvement of distant organs, especially the spleen. It will be recalled that the spleen is very rarely the site of metastasis in cases of carcinoma and sarcoma, though it is frequently involved in the leukaemias and reticuloses. Since there was nothing to suggest that these animals were suffering from a basophilic leukaemia of myeloid origin the possibility remains that their 'tumours' were local manifestations of a more generalized 'mast-cell reticulosis' (Cazal, 1942). Within the past few years evidence has accumulated that the underlying pathology of urticaria pigmentosa in man may perhaps rest on a similar basis (cf. Ellis, 1949; Nickel, 1957; Marshall et al, 1957; Remy, 1957; Beare, 1958). 
Irrespective of the precise nature of the pathological process, the present material settles beyond all reasonable doubt the view that tissue mast cells are extraordinarily rich in histamine and that, in most tissues at least, the bulk of the extractable histamine can be accounted for on this basis. It is thus of great interest that Graham and her associates $(1952$; 1955) find that much of the histamine in blood, especially in man, is likewise located in the basophils, or blood mast cells, though this is not necessarily true for all species (Code and Mitchell, 1957). Tissue mast cells are rich in histamine in all higher organisms so far examined. 


\title{
CHAPTER XI
}

\section{THE EFFECTS OF A SPECIFIC HISTAMINE-LIBERATOR, COMPOUND 48,80, ON THE MAST CELLS OF THE RAT}

\author{
(See Riley and West, 1955a)
}

\section{7}

HE original demonstration that mast cells store and release histamine, described in Chapter VIII, involved the use of rather toxic chemicals, some of which (e.g. stilbamidine, d-tubocurarine) have pharmacological actions which are unconnected with the release of histamine. It was therefore difficult to be certain that the disruption of the mast cells reflected only the release of histamine. The toxicity of these compounds also precluded prolonged study of their effects.

However, there is now available a more specific and a less toxic histamineliberator, compound 4880 (Paton, 1951; Paton and Schachter, 1951; Feldberg and Miles, 1953; Feldberg and Talesnik, 1953). This substance, a condensation product of $\mathrm{p}$-methoxyphenethylmethlyamine and formaldehyde, was therefore used in a further study of the tissue changes in three groups of rats subjected to intraperitoneal injection of compound $48 / 80$, (1) for one day only-'acute dosage', (2) for five days - 'subacute dosage', and (3) for thirty-one days'chronic dosage'. In addition there was a fourth group in which the drug was injected intra-arterially to allow study of a localized area of effect. For this the ear was chosen, since the ear in the rat has a very high content of mast cells. At selected times in each experiment appropriate tissues were taken for histamine assay and microscopical study of the mast cells.

The present work shows that a tissue depleted of its histamine by this histamine-liberator is devoid of mast cells and that the recovery or return of the mast cells is accompanied by a reappearance of assayable histamine. The long-term experiments confirm that compound $48 / 80$ is toxic to the rat only by virtue of its ability to release histamine: it is thus a specific histamine-liberator for this species.

\section{Materials and methods}

ANimaLs. In all, 170 young male rats (wt. 90-110 g.) of the Wistar strain were used. To obtain representative initial values of the histamine content of tissues, four control groups of six rats were killed by a blow on the head, and pooled tissues from each group were assayed. The experimental animals were killed in groups of seven, as follows: 'Acute dosage' expt., at days 
1, 4, 8, 15 and 32. 'Subacute dosage' expt., at days 3, 5, 11, 15, 18 and 32 . 'Chronic dosage' expt., at days 5, 15, 24 and 32.

On each occasion one animal from each group, chosen at random, was used for histological purposes, pooled tissues from the remainder being assayed for histamine. In the 'chronic dosage' experiment, four further groups of rats were injected intraperitoneally with a volume of saline equal to that used as a solvent for compound 48,80 and killed at the times stated. Again histamine values and the histological picture in each of these control groups were determined.

Histamine-liberator. Compound 48/80, kindly supplied by Messrs. Burroughs Wellcome and Co., was made up fresh in normal saline and injected intraperitoneally low down on the abdominal wall, the dosage, measured in micrograms ( $\mu \mathrm{g}$.$) , being as follows:$

'Acute dosage' expt. 100 (morning), 200 (afternoon).

'Subacute dosage' expt. Injection twice daily, starting at 100 per dose and increasing the dose by 100 each day to reach a dose of 500 on the fifth day.

'Chronic dosage' expt. Dosage as for 'subacute dosage' experiment for the first five days, thereafter single daily injections of 500 with increments of 100 every other day to reach 1000 per day, and continuing at this level of dosage once daily up to the thirty-first day of the experiment.

INTRA-ARTERIAL EXPERIMENT. Injections in this group were given into the artery of the ear. From previous work in which the vascular system of the rat was injected with coloured substances (Riley, 1953a) it was known that the main blood supply of the ear comes from the first branch of the external carotid artery. Accordingly this vessel was exposed in ten rats under ether anaesthesia by cutting the oblique muscle covering the carotid on the left side at its tendinous insertion under the mandible and retracting it posteriorly, at the same time turning the submaxillary salivary gland forwards to expose the entire cervical vessels. A hypodermic needle bent to a convenient shape was then inserted into the common carotid to lie in the origin of the external carotid. After the external carotid had been occluded beyond the branch to the ear by light pressure with a probe, a single dose of $200 \mu \mathrm{g}$. of compound 48/80 was injected slowly. Of ten rats so treated, eight subsequently developed erythema or cyanosis of the injected ear and were killed twenty-four hours later. The histamine content of pooled left ears from six rats was compared with the histamine content of pooled right ears (control) and then correlated with the histological findings in the ears of the remaining two animals.

Histamine ASSAY. For the estimation of histamine content mesentery, omentum and subcutaneous tissue were chosen because they all contain numer- 
ous mast cells. Sufficient subcutaneous tissue for this purpose can be obtained by scraping it off from under the surface of the excised skin. The mast cells of the rat ear are in the dermis, but for assay, since so little dermis is available, whole ears were employed.

These various tissues were extracted as previously described and were tested for histamine activity on the isolated guinea pig ileum preparation or on the blood pressure of the atropinized cat.

Microscopic EXAmination. Fresh tissue spreads of subcutaneous connective tissue, mesentery and omentum were prepared and fixed as previously described and stained with 0.1 per cent aqueous toluidine blue. In studying the ear it was found that once a narrow rim has been cut from its margin, the transparent epithelium and attached connective tissue can be peeled off the outer surface of the cartilage and glued to a slide, hairy side down, with a drop of B.P.S. mountant, which holds it there firmly during fixation in alcohol. On defatting with xylol, the preparation becomes detached and can be conveniently stained and differentiated in watch glasses until it is finally mounted under a weighted cover slip to keep it flat while the B.P.S. hardens.

\section{RESULTS}

\section{'Acute dosage' experiment}

Within a few minutes of the intraperitoneal injection of an appropriate dose of compound $48 \% 80$, the rat displays the characteristic signs of histamine release-shock, erythema followed by cyanosis of the ears, and, in extreme cases, visible oedema of the muzzle and extremities. The treated animals lie in isolation, not huddled together as they normally do. There is an obvious lowering of body temperature during the period of acute shock, but, given abundant drinking water, the animals soon recover.

MAST CELLS. In as short a time as three hours after the first intraperitoneal injection of compound 48/80, a striking change occurs in the peritoneum. Whereas in the controls injected with saline, the mast-cell picture is normal, the first impression of the stained spread of mesentery and omentum from the experimental rats is that the mast cells have completely disappeared. Even under high power it is difficult to find an intact mast cell in the mesentery: at most there remain a few irregular masses of darkly staining material near the smaller blood vessels whose endothelial nuclei now stain with the basic dye (Fig. 31). The mast cells scattered over the peritoneal windows have vanished. In the omentum this disappearance of mast cells is somewhat slower, but by one hour after the second injection the cells have undergone almost complete disruption. The milk spots are now crowded with round or amoeboid cells, each of which contains a few peripheral masses of 
darkly-stained material similar to the remnants around the mesenteric vessels; these cells are more suggestive of macrophages containing debris released from other cells than of mast cells in course of disruption.

One feature common to all regions in which mast cells are disappearing is the progressive swelling and increased basophilia of the connective-tissue cells in the adventitia of the small blood vessels, a process which seems to extend outwards from the vessels and ultimately to involve all the loose mesenchyme.

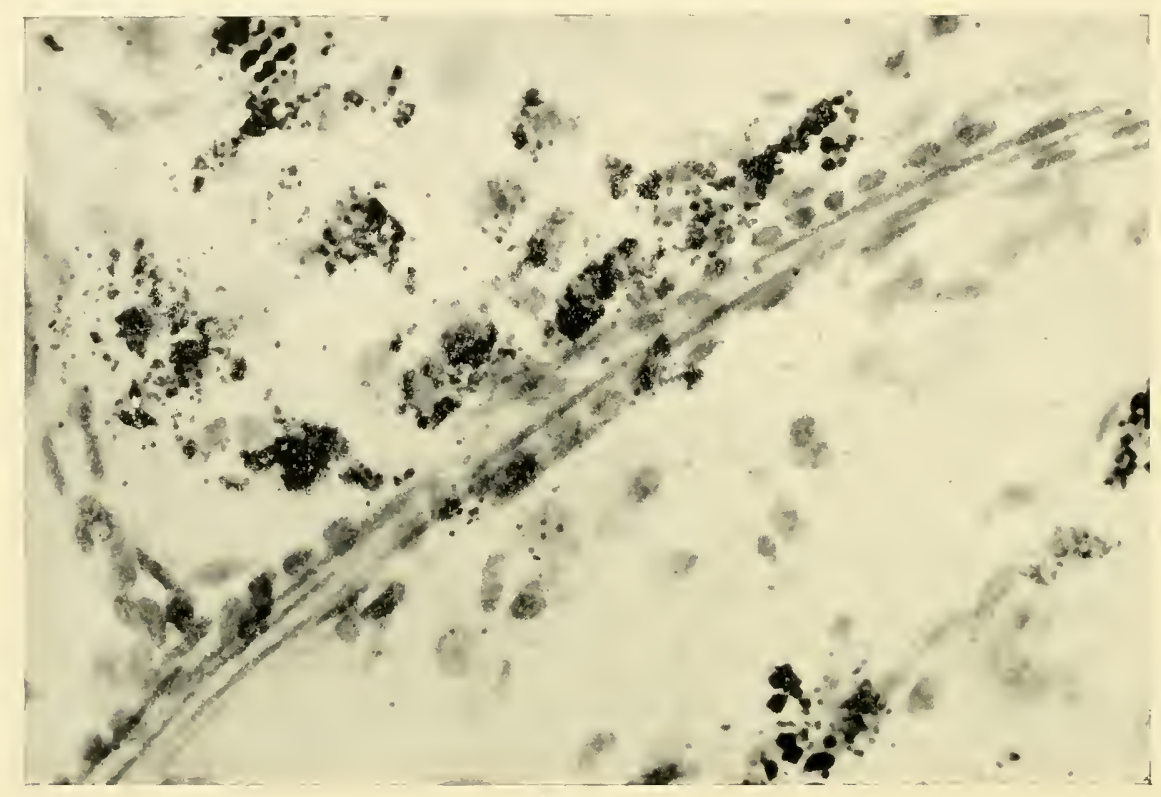

FIG. 31

'Acute dosage' experiment. Mesentery three hours after intraperitoneal injection of compound 48/80, showing shattered mast cells and early swelling and increased basophilia of the adventitial cells. Very little histamine remained in this tissue. Toluidine blue ( $\times 580)$. (Riley and West (1955), J. Path. Bact. 69, 269.)

As might be expected, the disruptive effects on the mast cells in regions remote from the injection site are less than in the peritoneal cavity itself. In the subcutaneous connective tissue the changes are often patchy in distribution, ranging from swelling and 'degranulation' of intact mast cells to the complete disruption of the cells and the scattering around them of pale orthochromatic granules. The nuclei of the swollen cells are themselves swollen and rather more basophil than normal. This general description of conditions in the subcutaneous connective tissue applies also to the ears except that more of the mast cells survive the early stages of the disruptive process.

By day four, the main histological feature in the 'acute dosage' experiment is the apparently complete restoration of the mast-cell picture in the subcutaneous 
connective tissue and ears. In contrast, the extent of recovery in the peritoneal cavity is limited. Well-stained mast cells are to be found in the adventitia of the main vessels framing the mesenteric windows, but in the windows themselves the cells are scanty and contain only a few pale and usually orthochromatic granules. Here the histological picture is dominated by the general activation

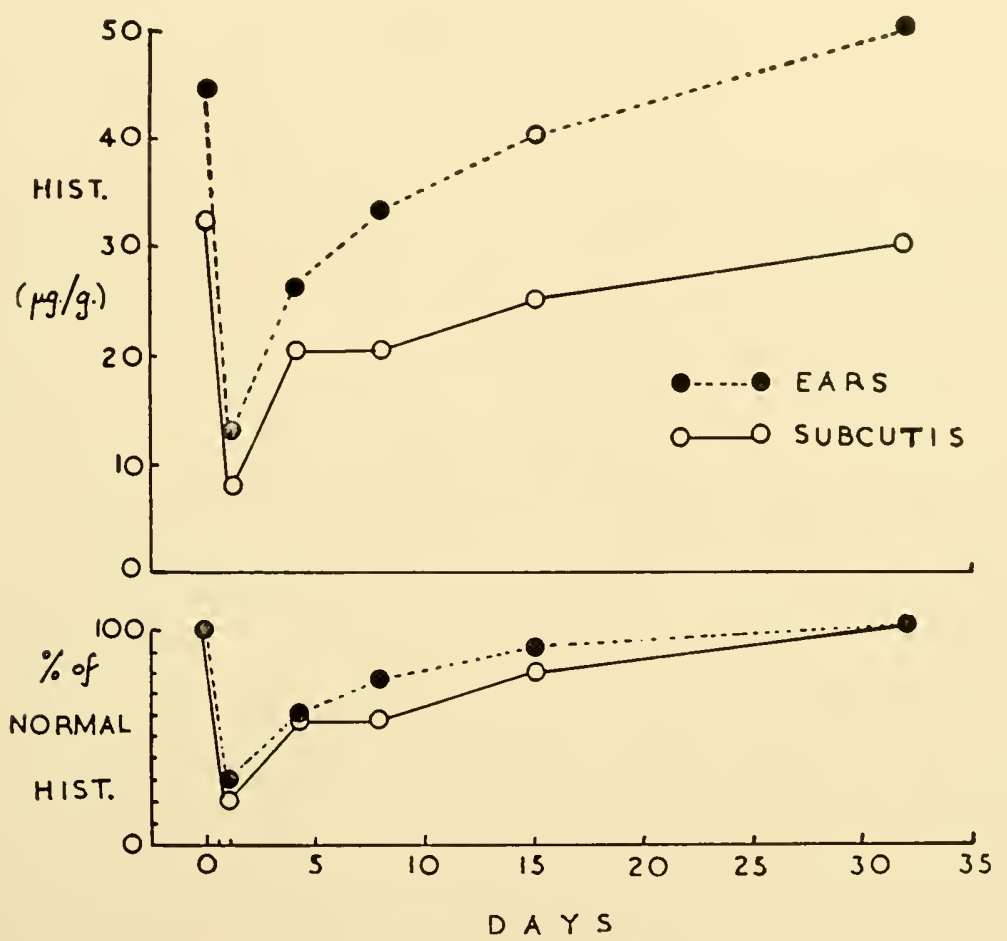

FiG. 32

'Acute dosage' experiment. Effect of two intraperitoneal injections of 48/80 on the histamine content of the subcutaneous connective tissue $(\mathrm{O}-\mathrm{O})$ and ears ( - . . - of rats. Histamine content expressed in $\mu \mathrm{g}$. $/ \mathrm{g}$. tissue in the upper tracings and in percentage of normal values in the lower tracings. Note the rapid recovery of tissue histamine. (Riley and West (1955), J. Path. Bact. 69, 269.)

and increased basophilia of the loose mesenchyme, the entire network of small blood vessels now standing out clearly in virtue of increased staining of the cells forming their adventitial sheaths. Numerous well-stained pleomorphic connective-tissue cells are also seen, scattered over the peritoneal windows and giving a general appearance curiously like that of a tissue culture. At this stage (day four) recovery is somewhat more advanced in the omentum, where the milk spots contain many normal and some small and pale mast cells. Many 
incompletely filled mast cells are seen in the delicate connective-tissue framework of the omentum.

Four days later (day eight) the omentum is virtually back to normal and there is further recovery in the mesentery, though in some areas the mesenteric windows are still devoid of mast cells or contain only occasional cells poor in

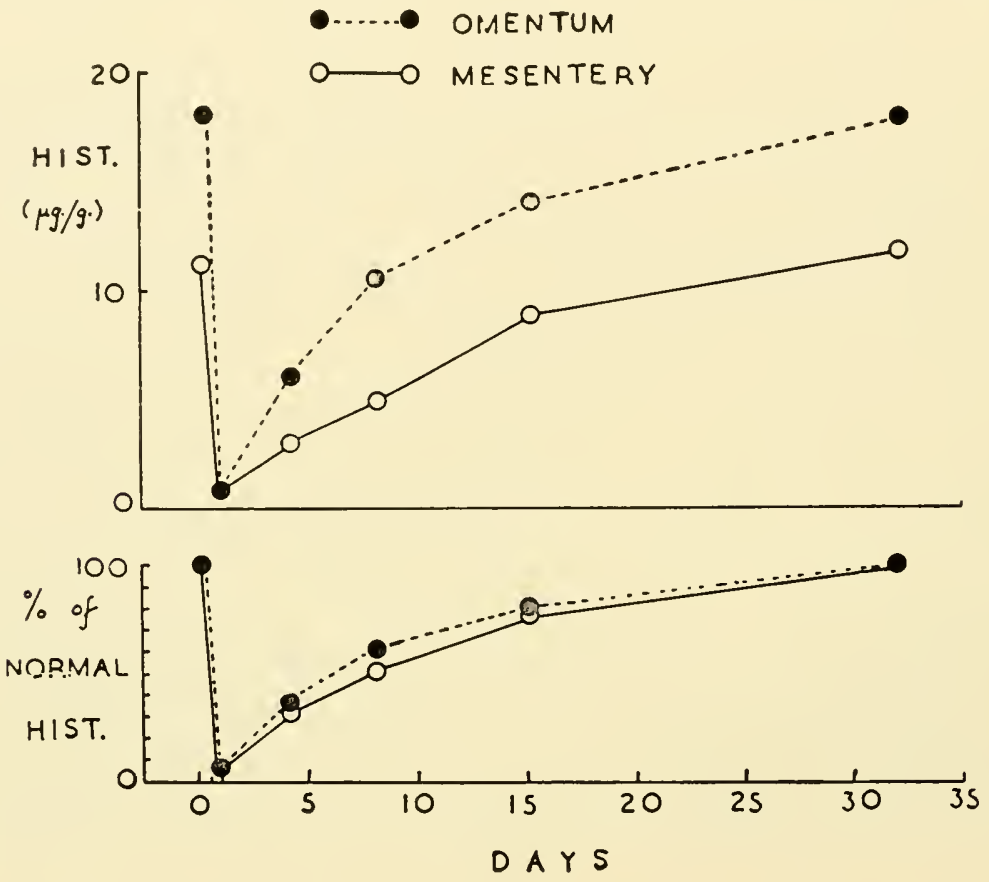

FIG. 33

Experiment as illustrated in Fig. 32. Histamine content of omentum ( . . . - •) and mesentery $(\mathrm{O}-\mathrm{O})$ shown in the tracings. (Riley and West (1955), J. Path. Bact. 69, 269.)

granules. The pleomorphic fibroblasts scattered over the windows are still present.

By day fifteen recovery in all areas is complete and the histological picture is normal.

Histamine. The changes in the histamine content of the four regions studied histologically are perhaps best seen in Figures 32 and 33, which show both the absolute and the percentage changes in tissue histamine over the period of the experiment. Briefly, the initial high values for the ears and subcutaneous connective tissue fall in twenty-four hours to approximately 30 and 20 per cent of normal, whereas in the case of mesentery and omentum, with lower starting values, the histamine at the end of twenty-four hours has all but vanished. 


\section{COMPOUND $48 / 80$ ON RAT}

Recovery is slowest in the mesentery, which, by day eight, contains only 45 per cent of its initial histamine. By day fifteen all the above-mentioned regions have achieved an 80 per cent recovery or better, and by day thirty-two, the restoration of tissue histamine is complete.

\section{'Subacute dosage' experiment}

In this group, injected intraperitoneally twice daily for five days with a steadily increasing level of dosage, the animals rapidly acquired tolerance and by the fifth day showed little evidence of histamine release following injection.

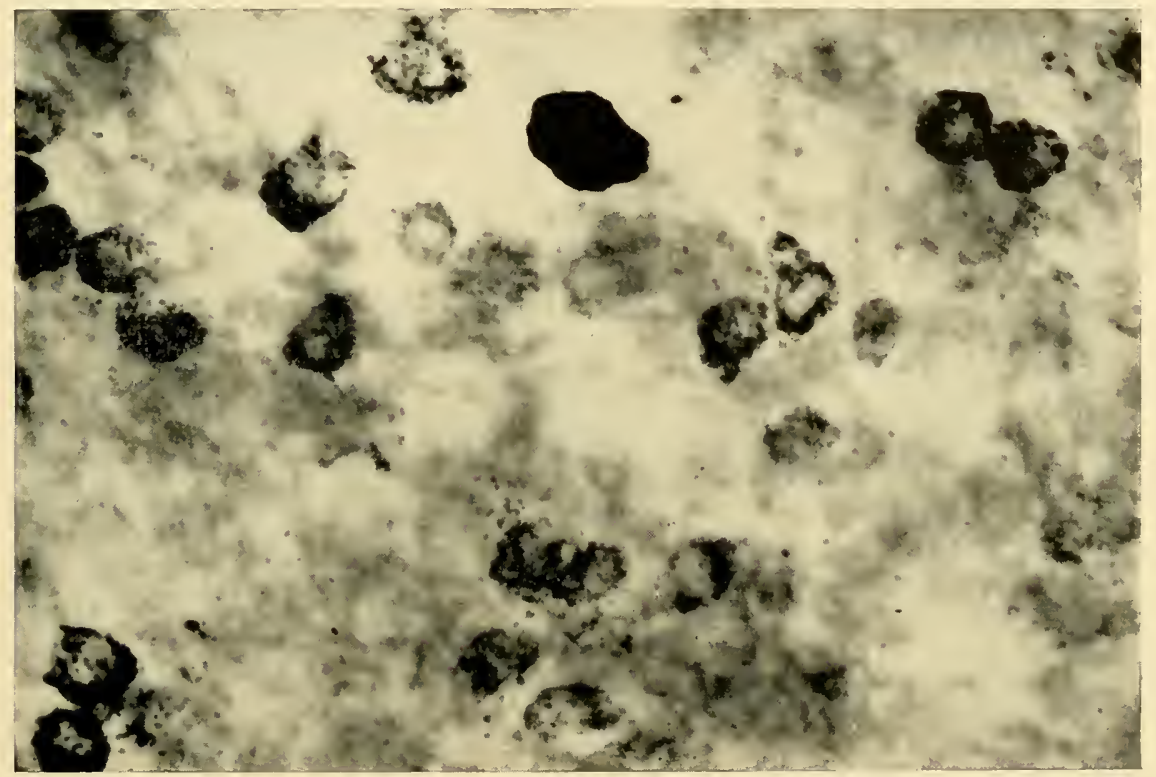

FiG. 34

'Subacute dosage' experiment. Subcutaneous connective tissue on third day of intraperitoneal injection of the histamine-liberator. One exceptionally large mast cell near the top remains unaffected. The remaining mast cells, in a slightly different tissue plane, all show varying stages of swelling and degranulation- 'ghost' cells. This is a reversible process. Toluidine blue $(\times 350)$. (Riley and West (1955), J. Path. Bact. 69, 269.)

MAST CELLS. Histological examination began on day three, by which time the mast cells in regions remote from the injection site already show changes far exceeding anything observed in the 'acute dosage' experiment. There is an absolute decrease in the number of mast cells in the subcutaneous connective tissue and in the skin of the ears. Such cells as remain are recognizable only by the presence of a few clumped granules or of small pale granules situated at the periphery of greatly swollen cells ('ghost' cells). These 'ghost' cells are well seen in the interspaces of the subcutaneous connective tissue (Fig. 34), the 
small vessels at the periphery of the area standing out distinctly owing to swelling, proliferation and increased staining of their adventitial cuffs. Adjacent fibroblasts also are often well stained and of bizarre shape.

A curious fact was noted in these animals. Both in the subcutaneous connective tissue and in the ears, the mast cells appear to escape entirely the

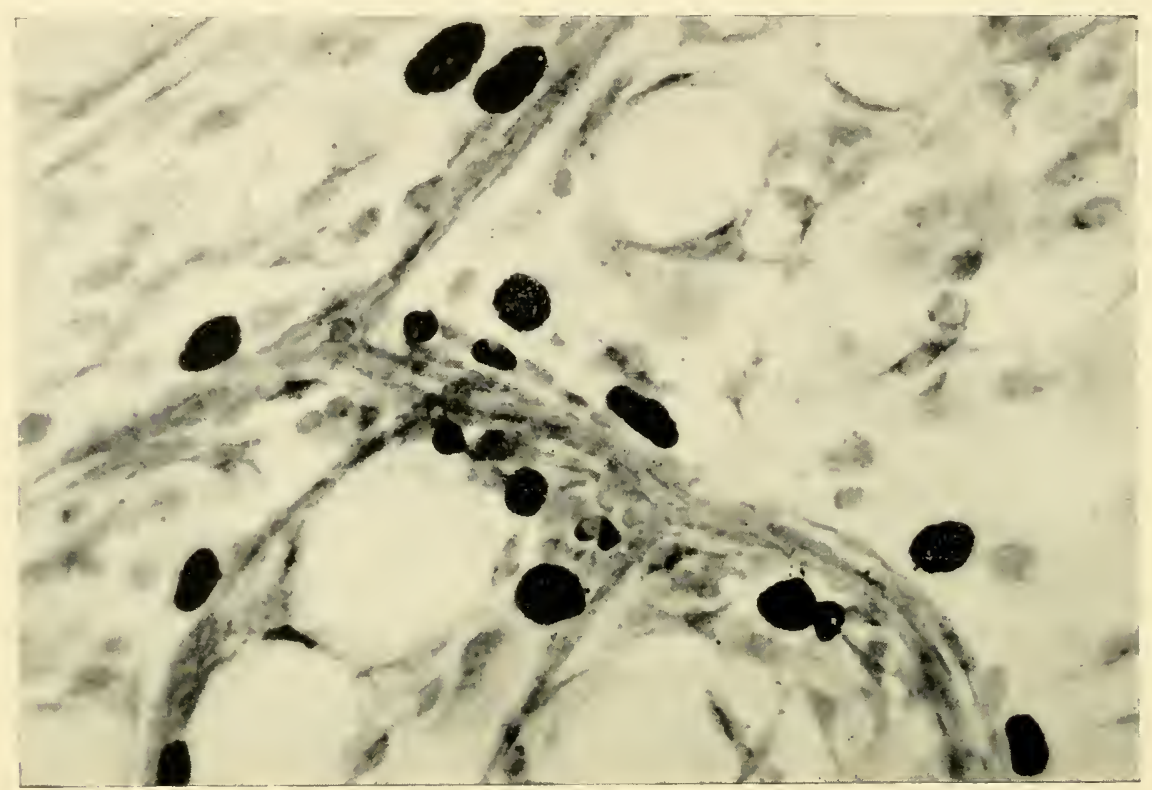

FIG. 35

'Subacute dosage' experiment. Omentum at day eleven, showing alternative ways in which the mast-cell population is restored after depletion by a histamine-liberator. The big cells are refilled 'ghost' cells. In addition, small new cells are forming from the adventitia of blood vessels and the septa of fat cells, as well as from scattered precursors in the loose connective tissue. Toluidine blue $(\times 450)$. (Riley and West $(1955)$, J. Path. Bact. 69, 269.)

effects of the histamine-liberator if they lie in the perineurium of the peripheral nerves. Indeed, these nerves can be readily traced, under the low-power objective, because of this persistence in the nerve sheath of its normal complement of small, spindle-shaped mast cells.

By day five no mast cells are visible in the mesentery, such granular cells as are seen being macrophages containing basophilic debris. The vascular network is again very obvious, thanks to the adventitial proliferation. In the omentum, similar adventitial changes are present. The small cells forming the centres of the milk spots are deeply stained: in and around the milk spots, macrophages are numerous but there are no mast cells. Similarly, there are no identifiable mast cells in the ear or in the subcutaneous connective tissue. 


\section{COMPOUND $48 / 80$ ON RAT}

Recovery is remarkably rapid once the injections have ceased, despite the extent to which the mast cells appear to have been damaged by the repeated injections. In as short a time as four days (day nine of the experiment), there is substantial restoration of the mast-cell pattern in the skin of the ear and even more so in the subcutaneous connective tissue. It is noteworthy that these are

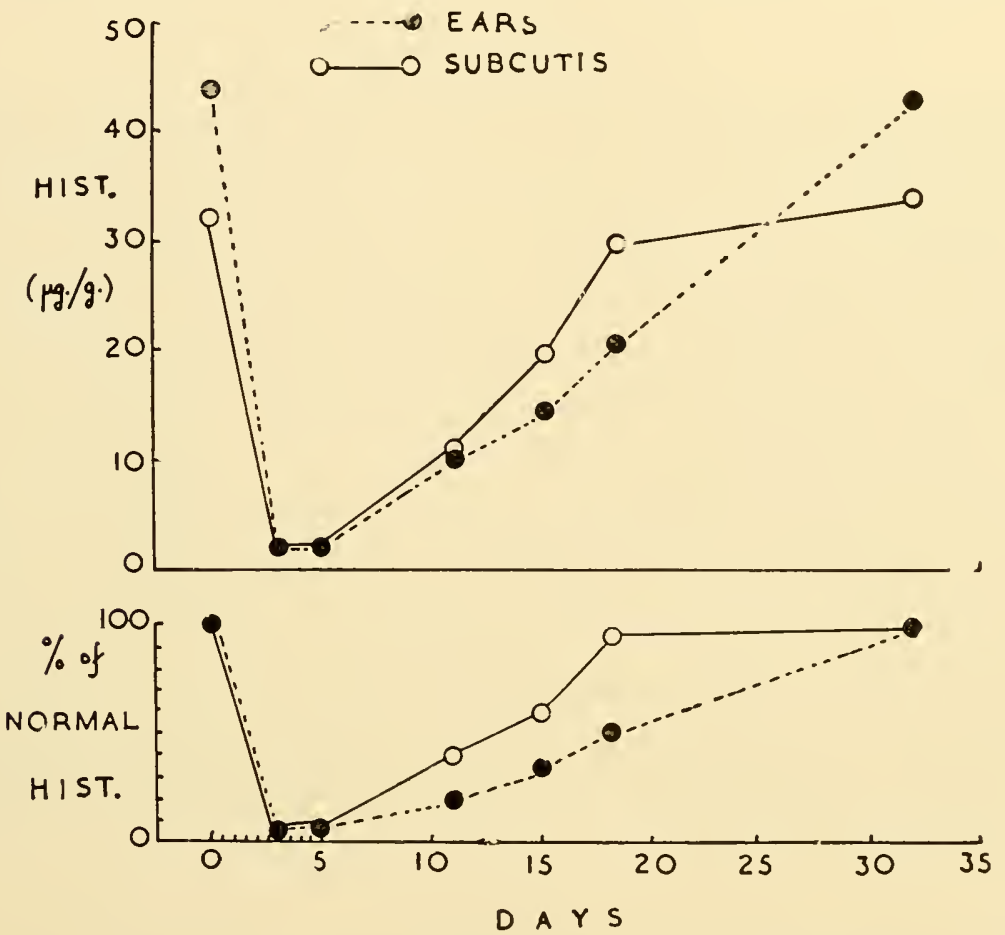

FIG. 36

'Subacute dosage' experiment. Effect of $48 / 80$ (given over five days) on the histamine content of subcutaneous connective tissue $(\mathrm{O}-\mathrm{O})$ and ears (1....- of rats. Histamine content expressed in $\mu \mathrm{g}$. $/ \mathrm{g}$. tissue in the upper tracings and in percentage of normal values in the lower tracings. Note the slower recovery of tissue histamine, particularly in the ears. (Riley and West (1955), J. Path. Bact. 69, 269.)

almost all large cells, though poor in granules. Such large 'ghost' mast cells appear occasionally in the peritoneum, especially near vessels of intermediate size. In addition, however, both in the mesentery and in the omentum numerous very small mast cells, each containing a few minute granules, are now appearing in the adventitia among similar oat-shaped but non-granular cells which lie with their long axes parallel to the vessel wall.

By day eleven these small new cells are common throughout the peritoneum and are seen particularly clearly in the delicate connective-tissue framework of the omentum, where they are not obscured by other structures (Fig. 35). In 
the mesentery a wave of such cells can sometimes be observed spreading over a peritoneal window from the fatty fringe which surrounds it; and within the fatty fringe itself small attenuated mast cells lie closely applied to the septa of fat cells and apparently arising from them. The fat cells in mesentery and omentum thus come to have a signet-ring appearance (Fig. 35). Gradually
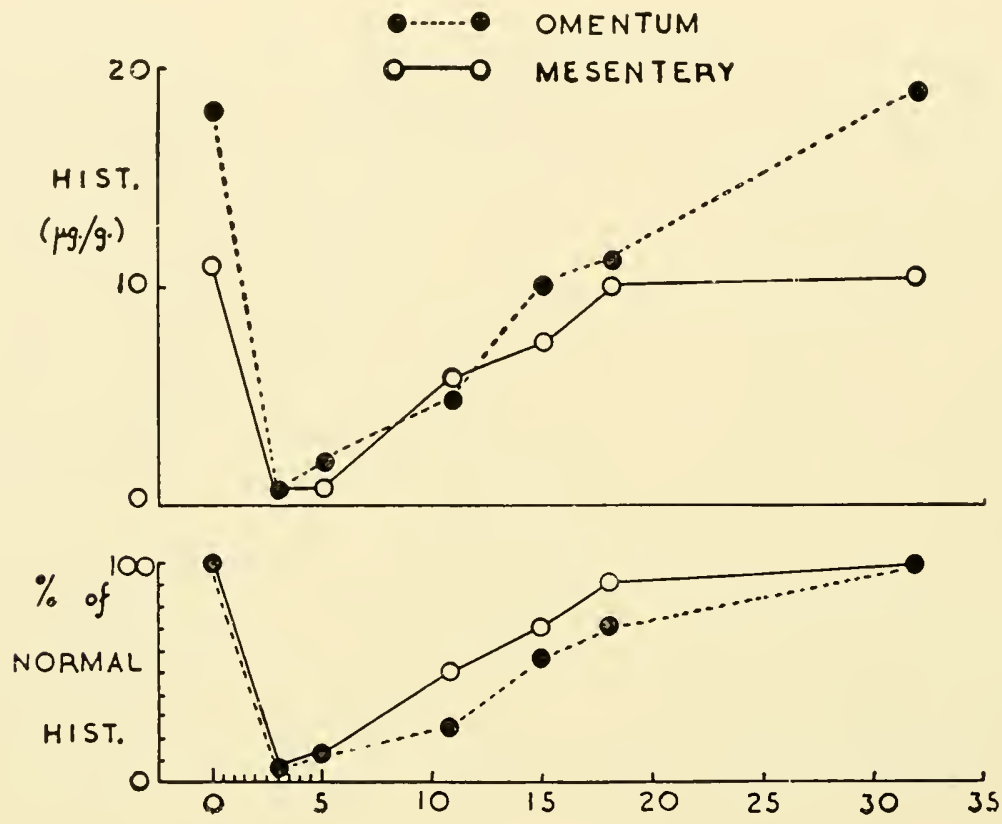

DAY 5

FIG. 37

Experiment as illustrated in Fig. 36. Histamine content of omentum ( . . . - $)$ and mesentery $(\mathrm{O}-\mathrm{O})$ shown in the two tracings. (Riley and West (1955), J. Path. Bact. 69, 269.)

all these small cells increase in size and fill with granules until, by day eighteen, the two types of mast cell (refilled 'ghost' cells and hypertrophied small cells) can no longer be distinguished. Even the accentuated vascular pattern of the peritoneum has now returned to normal, leaving here and there clumps of organizing fibroblasts embedded in a metachromatic ground substance and surrounded by small dark mast cells.

HistaminE. The chief difference in the histamine pattern between the 'acute dosage' and 'subacute dosage' experiments is that in the latter the precipitous fall at the beginning of the experiment (affecting alike all tissues studied) is followed by a slower rate of recovery, especially in the skin of the ear (Figs. 36 and 37 ). Thus at day eighteen the ears show only 50 per cent restoration of 


\section{COMPOUND $48 / 80$ ON RAT}

histamine, whereas the subcutaneous connective tissue is aimost back to normal. By day thirty-two recovery is complete in all four regions studied histologically.

\section{'Chronic dosage' experiment}

It is necessary here to describe only the histological appearances from day five onwards, since this experiment was in fact an extension of the subacute

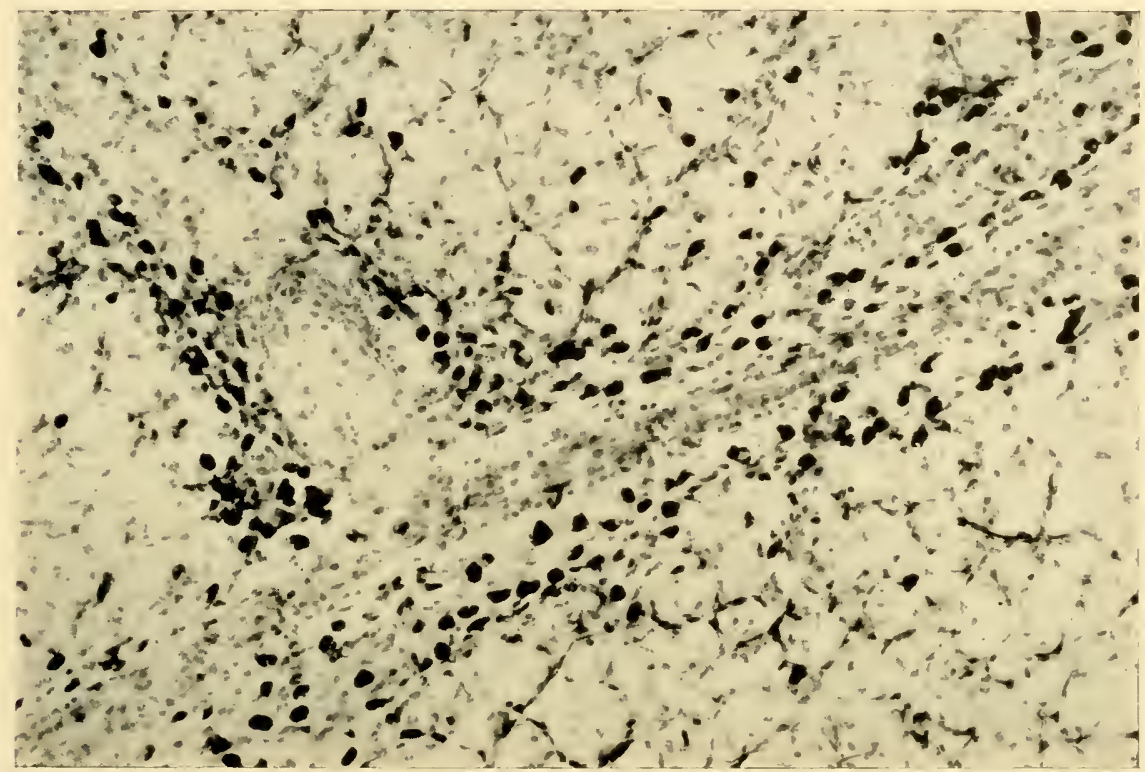

FIG. 38

- Chronic dosage 'experiment. Subcutaneous tissue at day thirty-two. Despite continued intraperitoneal injection of compound 48/80 (1 mg./day), numerous small mast cells are now appearing around the blood vessels. There was a corresponding return of the tissue histamine. Toluidine blue $(\times 220)$. (Riley and West (1955), J. Path. Bact. 69, 269.)

(five-day) experiment, daily doses of histamine-liberator being administered thereafter for a further twenty-six days. It is of pharmacological interest that during this period there was no mortality despite the repeated injection of even $1 \mathrm{mg}$., thus confirming the low intrinsic toxicity claimed for compound 4880.

MAST CELLS. Throughout the period of injection there is little evidence of recovery of mast cells in either mesentery or omentum. In the mesentery no perivascular mast cells are to be seen, and the only scattered ones are in relation to patches of organizing exudate; their granules are small and pale. In contrast, macrophages laden with debris are very common, being especially numerous in the omentum. Characteristic of the omentum, too, in this group 
of rats is a hyperplasia of the adventitial tissue and milk spots, without, however, any reappearance of typical mast cells. Occasional granular cells are seen but they are very rare. In the control group of rats, the mast-cell picture is normal, apart from an occasional pale or 'punctate' mast cell in the mesenteric windows and a few additional polymorph leucocytes in the omentum. If anything,
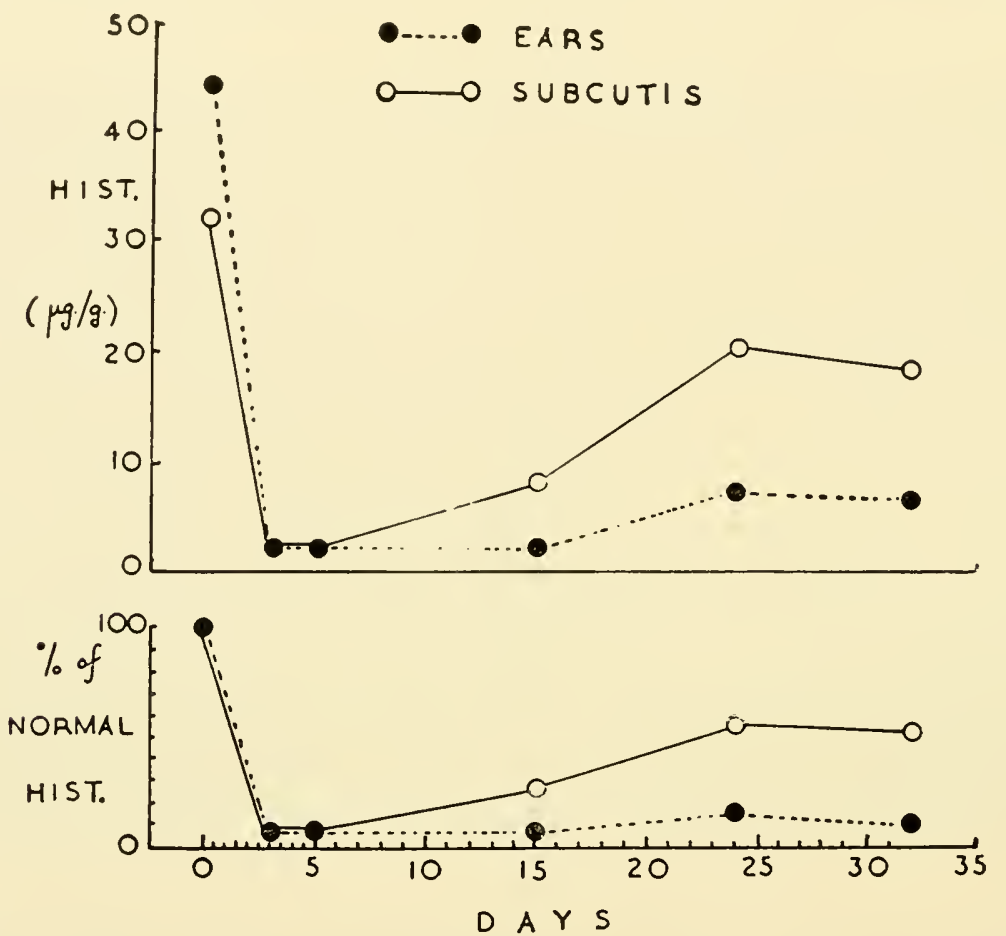

FiG. 39

'Chronic dosage' experiment. Effect of $48 / 80$, given over thirty-one days, on histamine content of subcutaneous connective tissue $\left(\mathrm{O}_{-} \mathrm{O}\right)$ and ears (-...-) of rats. Histamine content expressed in $\mu \mathrm{g}$./g. tissue in the upper tracings and in percentage of normal values in the lower tracings. Note the partial recovery in the histamine content of the subcutaneous connective tissue, despite the continued dosage of 48/80. (Riley and West (1955), I. Path. Bact.

69, 269.)

there is an increase rather than a decrease in the number of omental mast cells in the saline-treated controls.

As the experiment proceeds an interesting difference emerges between the appearance of the mast cells in the two remote tissues, ears and subcutaneous tissue. Mast cells progressively disappear from the ears (with the exception of the nerve sheaths) and remain absent thereafter. In the subcutaneous connective tissue, on the other hand, the inital disappearance of the cells is followed by the gradual development of numerous minute mast cells in the adventitia of 


\section{COMPOUND $48 / 80$ ON RAT}

small blood vessels with muscle coats until, by day thirty-two, many of these vessels are surrounded by several layers of small, darkly-staining mast cells (Fig. 38).

Histamine. As Figures 39 and 40 indicate, continued injection of compound 48 80 largely suppresses the restoration of the tissue histamine, with the notable

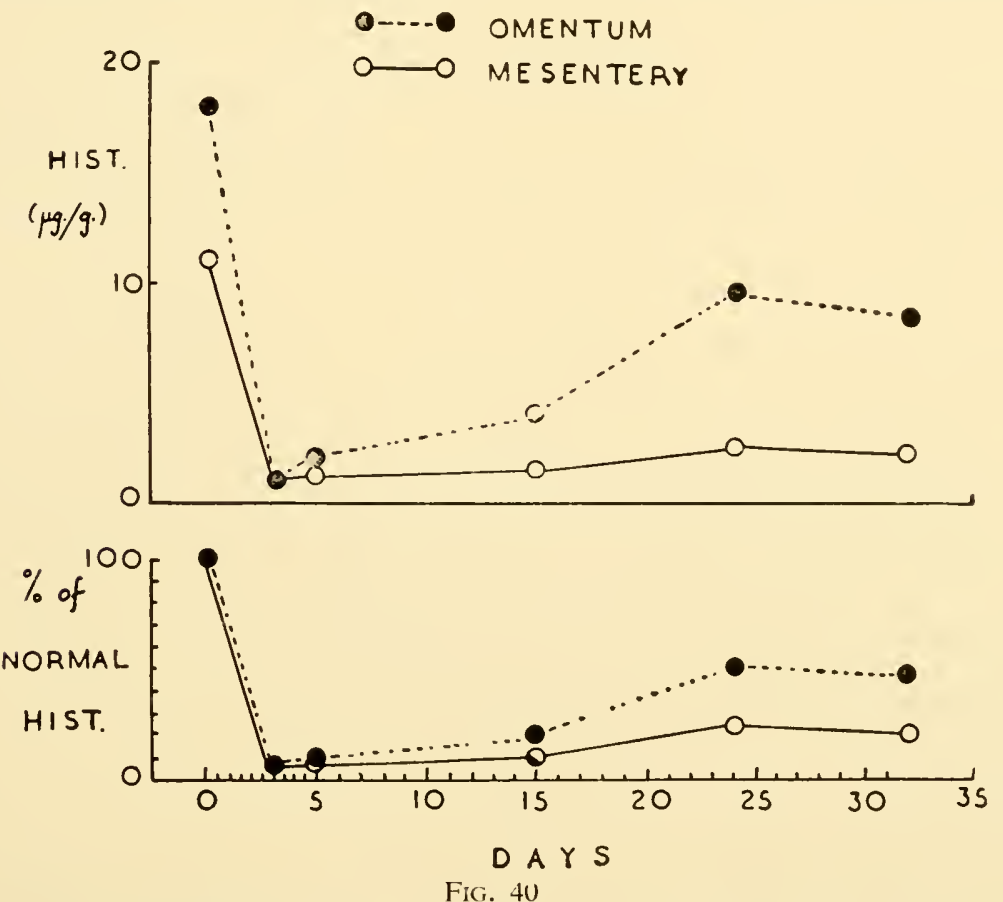

Experiment as illustrated in Fig. 39. Histamine content of omentum and mesentery $(\mathrm{O}$

O) shown in the two tracings. (Riley and West (1955), J. Path. Bact. 69, 269.)

exception of the subcutaneous connective tissue, in which a recovery of 50-60 per cent of normal is achieved by the thirty-second day. The omentum, too, shows a somewhat lesser recovery of up to 40-50 per cent of normal, and here we observed that when an extract of this omentum was tested on the cat's blood pressure the initial fall due to histamine itself in the extract was followed after a few seconds by a further fall, indicative of the presence of a histamineliberator. This may well be some of the compound $48 / 80$ which had been used in the experiment.

\section{Intra-arterial injection}

In this group only those animals were examined in which, judging by the subsequent erythema of the ear on that side, the intra-arterial injection had been successful. 
MAST CELLS. In brief, the mast-cell picture of the injected ears twenty-four hours after operation closely resembles that seen on day three of the "subacute dosage' experiment, there being widespread disruption of the mast cells. In contrast, the ears on the opposite side which had not been directly injected appear normal. However, it should be mentioned that in one animal there were also signs of damage to mast cells in the mesenteric windows.

Histamine. There was a significant difference in the histamine content of the ears on the two sides twenty-four hours after injection, the injected ears containing only an average of $6 \mu \mathrm{g}$. g. histamine as against $27 \mu \mathrm{g}$. g. for the opposite ears of the same animals. The latter figure is somewhat low, an average value for the ears of an untreated rat being $44 \mu \mathrm{g}$. g. Presumably some of the injected 48,80 had reached the general circulation.

\section{Discussion}

The main fact emerging from these experiments on rats treated in various ways with the powerful histamine-liberator, compound $48 / 80$, is the parallelism which exists between the histamine value of a particular tissue and its mast-cell content. Thus, in the present work, the transitory fall of histamine in the 'acute dosage' experiment, the more prolonged fall in the 'subacute dosage' experiment, and the sustained reduction in tissue histamine in the "chronic dosage' experiment, are all reflected in the changes in the mast-cell population of the four tissues studied.

\section{Specificity and low toxicity of compound $\mathbf{4 8} 80$}

Intense shock follows the initial injection of compound 48,80 into the peritoneal cavity of the rat. Soon, however, the animal acquires tolerance to further daily doses which would once have been fatal. This gradual acquisition of tolerance corresponds to the progressive loss of tissue histamine; and having acquired tolerance the rats display no further signs of toxicity for at least thirty days, the period of the 'chronic dosage' experiment.

Thus we see that compound $48 / 80$ produces shock in the rat only when there is histamine to be liberated and that once the tissues are free of histamine, compound $48 / 80$ is no longer toxic. Its action in the rat, then, is that of a specific histamine-liberator.

\section{Site of action of compound 4880}

It is probable that histamine can be released in various ways, and it is thought by some that the most common mechanism is through the activation of a proteolytic enzyme in the blood (Rocha e Silva, 1953). However, the ability of compound 48,80 to release histamine in the rat would appear to 
depend on a direct interaction between the histamine-liberator and some component of the tissues themselves. This is evident, since the tissue which first loses histamine and loses it in greater amount is the tissue with which the liberator first comes into contact (Feldberg and Talesnik, 1953). After intraperitoneal injection of compound 48,80 the mesentery and omentum promptly release their histamine, followed in due course by the subcutaneous tissue and ears. But when the experimental conditions are altered and the liberator is injected direct into an artery leading to another area, the ear, the loss of histamine is almost entirely confined to that tissue. Thus we may infer that the clue to the action of compound $48 / 80$ as a liberator of histamine will be found in the tissues and not in the blood.

\section{The mast cell as the target for compound 4880}

So far as present evidence goes, the mast cell is the first component of a living tissue to react to a local concentration of compound 48 80. Topical application on to a serous surface by means of intraperitoneal injection is followed by rapid dissolution of the subserous mast cells. Moreover, the mast cells and the histamine disappear together. Later, as the cells regenerate, the histamine content of the tissue again increases. This is well shown in the 'chronic dosage' experiment, in which there is partial restoration of mast cells in the subcutis but not in the ear, the histamine values running parallel with the mast-cell status of each. The disruptive effect of compound 48,80 on the mast cells has even been observed in tissue spreads in vitro (Mota et al, 1953), a finding which I have confirmed. Norton (1954) was able to utilize the phenomenon for assaying batches of compound 48 80: she also confirmed the protective action of the antihistamines, as described by me for the diamidines (Norton and de Beer, 1955). All the evidence therefore points to the mast cell as the component of a tissue on which compound 48,80 acts to release histamine.

\section{Dosage effect of compound 4880 on the mast cells}

Intraperitoneal injection of compound 48/80 produces an almost explosive destruction of the abdominal mast cells, and in the ear subjected to intraarterial injection there is again evidence of direct damage. On the other hand, examination of tissues at some distance from the site of injection (the subcutaneous tissues and the ear tissues of rats injected intraperitoneally) reveals a slower and lesser effect on the mast cells. In these distant sites the cells become swollen and their granules lose their affinity for basic dyes ('ghost' cells) until at length they are no longer recognizable as mast cells.

The phenomena of the recovery phase also differ. Thus the peritoneal mast cells are slowly restored through the development of new cells from small 
precursors in the adventitia of blood vessels, the septa of fat cells and the milk spots and connective tissue framework of the omentum. On the other hand, the mast cells in distant tissues reappear at once as large 'ghost' cells which rapidly regain their basophilic granules. Since a few intermediate forms can be found in all areas, we believe that these different sequences represent the response to different doses of compound 48 80. Rather similar conclusions were drawn by Fawcett (1954), who studied the peritoneal mast cells of rats after injecting graded doses of compound 48/80. It seems clear, therefore, that although high dosage of a histamine-liberator kills mast cells from which the histamine has been released, a more moderate dose effects a reversible change, leaving the cells capable of recovery, as evidenced by re-formation of stainable granules. It is probable that this reversible process represents the normal mechanism of histamine release.

\section{Secondary effects of histamine release}

Among the incidental observations made in this work, the activation of the loose mesenchyme which follows damage to the mast cells may prove to be of physiological importance. It will be recalled that, as the mast cells disappear, there is progressive swelling, basophilia and evidence of mobility of various connective tissue cells, first of the adventitia itself and later of cells at increasing distances from the blood vessels. Indeed, in such a tissue as the mesentery, the histological picture soon comes to be dominated by the deeply stained and swollen cells in the adventitia of the small blood vessels and by the appearance of similar well-stained pleomorphic cells scattered over the peritoneal windows. Some of these cells eventually become mast cells, some are evidently macrophages, but the majority appear ultimately to return to a state of quiescence as the mast cells refill with granules. One wonders, therefore, whether this temporary activation of the loose mesenchyme might not result from the flooding of the tissues with a protein-rich oedema fluid consequent upon the release of histamine (Drinker and Yoffey, 1941; Feldberg, 1954). If so, it might indicate a physiological role for histamine in the inflammatory reaction. 


\title{
COMPARISON OF THE EFFECTS OF THE SAME HISTAMINE- LIBERATOR (COMPOUND 48 80) ON TWO CLOSELY ALLIED SPECIES, MOUSE AND RAT
}

(See Riley and West, 1955b)

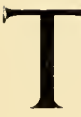
HE work described in the previous section indicates clearly that compound $48 / 80$ is a specific and highly effective histamine-liberator for the rat, releasing histamine from its depots in the tissue mast cells. However, other workers have shown that compound $48 / 80$ is less effective as a histamineliberator in certain other species, notably the guinea pig (Feinberg and Sternberger, 1955). It was thus of interest to compare its effects on two closely allied species, the mouse and rat. As before, the action of the liberator was studied both in short-term and in long-term experiments.
\end{abstract}

\section{Methods}

The present study involved the use of ninety-four young male rats (weight 90-110 g.) of the Wistar strain, and 126 male albino mice (weight 19-21 g.). To obtain representative initial values for the histamine content of tissues, four groups of six rats and four groups of nine mice were killed by a blow on the head, and pooled tissues from each group were assayed. The experimental animals were killed in groups of seven rats and of ten mice, as follows:

Short-term experiment, at days 3, 5, 11, 15, 18, 32 (rats); and 3, 8, 15, 21, 32 (mice).

Long-term experiment, at days 5, 15, 24, 32 (rats); and 3, 8, 15, 21, 32 (mice). On each occasion one animal chosen at random from each group was used for histological purposes, pooled tissues from the remainder being assayed for histamine.

The histamine-liberator, compound 48/80, kindly supplied by Messrs. Burroughs Wellcome and Co., was made up in fresh normal saline for injection intraperitoneally low down on the abdominal wall, the dosage being as follows:

SHORT-TERM EXPERIMENT: Rats-injections twice daily ( 9 a.m. and 5 p.m.), starting at $100 \mu \mathrm{g}$. per dose and increasing the doses by $100 \mu \mathrm{g}$. each day to reach doses of $500 \mu \mathrm{g}$. on the fifth day.

Mice-injections twice daily, starting at $50 \mu \mathrm{g}$. per dose and increasing the doses by $50 \mu \mathrm{g}$. each day till the fourth day when doses of $150 \mu \mathrm{g}$. and $200 \mu \mathrm{g}$. were used. On the fifth day both doses were of $200 \mu \mathrm{g}$. 
LONG-TERM EXPERIMENT: Rats-dosage as for short-term experiment for the first five days, thereafter single daily injections of $500 \mu \mathrm{g}$. with increments of $100 \mu \mathrm{g}$. every other day to reach $1 \mathrm{mg}$. per day and continuing at this level of dosage once daily up to the thirty-first day of the experiment.

Mice-dosage as for short-term experiment for the first five days, thereafter single daily injections of $200 \mu \mathrm{g}$. for five days, then $250 \mu \mathrm{g}$. for five days, and finally $300 \mu \mathrm{g}$. once daily up to the thirty-first day of the experiment.

The ears and subcutaneous connective tissue (obtained by removing the skin and scraping off the tissue from the under surface) were selected for estimation of their histamine content. This was assayed on the isolated guinea pig ileum preparation in the presence of atropine or on the blood pressure of the atropinized cat. Representative tissue spreads were prepared, fixed, and stained with toluidine blue for mast cells as previously described.

\section{RESULTS}

\section{Short-term experiments}

SHORT-TERM EXPERIMENT IN RATS. The first intraperitoneal injection of $100 \mu \mathrm{g}$. of compound 48/80 produces in rats shock, erythema followed by cyanosis of the ears, and visible oedema in certain regions of the skin. This oedema appears to be dependent on the presence of available histamine, for the ears and feet are the usual sites of early swelling and these tissues are rich in both histamine and mast cells. Severe itching seems to occur in both regions. The amounts of histamine released by the liberator and circulating subsequently in the body decrease with each injection of compound $48 / 80$, until at day three the histamine content of the ear and subcutaneous connective tissue is reduced to some 3-7 per cent of its original value (Table XIV and Fig. 41).

\section{TABLE XIV}

$$
\begin{gathered}
\text { Histamine content of tissues of rats following } \\
\text { treatment with } 48 / 80 \text { over } 5 \text { days (Short-term } \\
\text { experiment) }
\end{gathered}
$$

Values expressed in $\mu \mathrm{g} . / \mathrm{g}$. tissue

\begin{tabular}{|r|c|c|}
\hline Day & $\begin{array}{c}\text { Subcutaneous } \\
\text { connective tissue }\end{array}$ & Ears \\
\cline { 1 - 2 } & 32 & 44 \\
3 & 1 & 2 \\
5 & 1 & 3 \\
11 & 13 & 11 \\
15 & 20 & 16 \\
18 & 30 & 22 \\
32 & 33 & 42 \\
\hline
\end{tabular}


At this stage there is an absolute decrease in the number of mast cells in both ear and subcutis, such cells as remain being recognizable only by the presence of a few clumped granules or of small pale granules situated at the periphery of greatly swollen 'ghost' cells. At day five there is no further visible damage to the mast cells, and signs of itching, cyanosis and oedema are no longer provoked.

In as short a time as six days after the last injection (day eleven of the experiment) there is substantial restoration of the mast-cell pattern in the skin

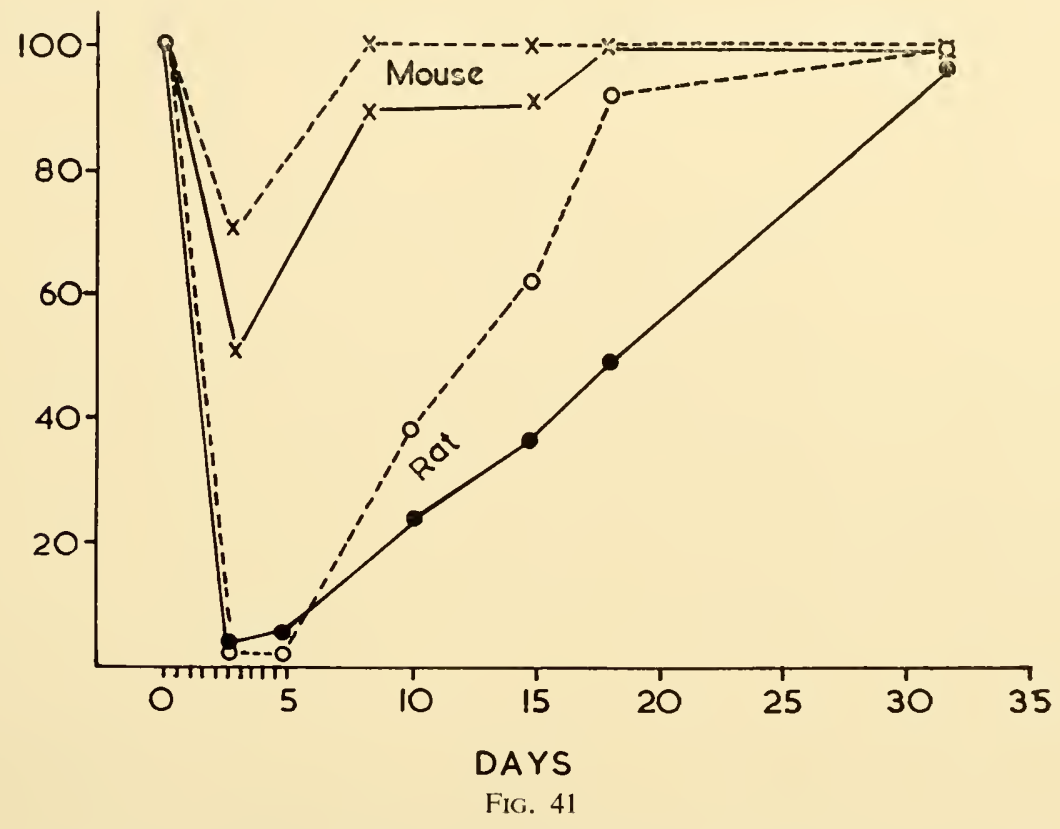

Short-term experiment. Effect of compound 48/80, given over five days, on the histamine content of subcutaneous connective tissue (dotted lines) and ears (solid lines) of mouse and rat: histamine values expressed as per cent of normal. Compound $48 / 80$ is about twice as effective in the rat as in the mouse. Both species recover rapidly.

of the ear and especially in the subcutis, and it is noteworthy that these are almost all large, adult cells though poor in granules. This histological recovery is also matched by a rise in the tissue histamine, the ear showing a restoration to about 24 per cent of its normal value, whereas the subcutis is restored to about 39 per cent of normal. By day eighteen the two tissues are refilling with mast cells of normal adult size though again the ears tend to show a slower rate of recovery than the subcutaneous connective tissue. At this stage the histamine content of the ears is 50 per cent of normal, whereas the histamine in the subcutis is almost fully restored. By day thirty-two recovery is complete in both regions studied (Fig. 41). 
SHORT-TERM EXPERIMENT IN MICE. The first intraperitoneal injection of $50 \mu \mathrm{g}$. of compound 48,80 produces weakness and cyanosis in mice but there is little evidence of severe itching. The ears display erythema but oedema is slight. A second injection of the same dose of the liberator eight hours later produces a similar result. Even when the dose is raised considerably (to $200 \mu \mathrm{g}$.), redness of the ears and general weakness are still observed but there is no scratching. Biological assays indicate that the loss of tissue histamine does not exceed 50 per cent in the skin of the ears or 30 per cent in the subcutaneous connective tissue (Table XV and Fig. 41). Disruption of mast cells has occurred in these regions but it is patchy in distribution, and many mast cells in the ear seem to survive.

\title{
TABLE XV
}

\begin{abstract}
Histamine content of tissues of mice following treatment with 48/80 over 5 days (Short-term experiment)

Values expressed in $\mu \mathrm{g}$./g. tissue
\end{abstract}

\begin{tabular}{|c|c|c|}
\hline Day & $\begin{array}{c}\text { Subcutaneous } \\
\text { connective tissue }\end{array}$ & Ears \\
\cline { 1 - 2 } 0 & 28 & 50 \\
3 & 20 & 25 \\
8 & 28 & 45 \\
15 & 30 & 45 \\
21 & 30 & 50 \\
32 & 29 & 50 \\
\hline
\end{tabular}

At day eight (three days after cessation of injections) biological assays indicate that rapid recovery of tissue histamine has occurred; correspondingly the histological picture shows a complete restoration of the mast cells in both areas. Thus it seems that tissue mast cells in the mouse are more resistant to the disruptive action of compound 48/80 than they are in the rat.

\section{Long-term experiments}

LONG-TERM EXPERIMENT IN RATS. This experiment is, in effect, an extension of the short-term experiment. Despite the continued daily injections of even $1 \mathrm{mg}$. of the liberator there is no mortality and the clinical signs of histamine release at this dose level are virtually absent. Nevertheless, regional differences are seen in the mast cells, as described earlier in this book. The cells progressively disappear from the ears (except in the nerve sheaths) and remain absent thereafter. However, in the subcutaneous connective tissue, the initial disappearance of the cells is followed by the gradual re-development of numerous mast cells in the adventitia of the small blood vessels with muscle coats, until by day thirty-two many of these vessels are surrounded by several layers of 
small, darkly staining cells. These changes are again reflected in the histamine values (Table XVI and Fig. 42), the initial depletion in the subcutaneous connective tissues (to 6 per cent of normal) being followed by a recovery to about 60 per cent of normal.

\section{TABLE XVI}

Histamine content of tissles of rats following treanment with 48/80 over 31 days (Long-term experiment)

Values expressed in $\mu . g . g$. tissue

\begin{tabular}{|c|c|c|}
\hline Day & $\begin{array}{c}\text { Subcutaneous } \\
\text { connective tissue }\end{array}$ & Ears \\
\cline { 1 - 2 } 0 & 32 & 44 \\
5 & 2 & 3 \\
15 & 8 & 3 \\
24 & 20 & 7 \\
32 & 16 & 7 \\
\hline
\end{tabular}

LONG-TERM EXPERIMENT IN MICE. Continued dosage brings out a significant difference between the rat and the mouse in response to injections of a histamineliberator. The initial decrease in the histamine content of the tissues (to 50 per cent of normal) seen in both species is not progressively continued in the mouse despite the relatively large daily doses of the liberator (Table XVII and Fig. 42). By day thirty-two, groups of mast cells are still present in the ears and subcutaneous connective tissue of mice. They appear to be resistant to these doses of the liberator, which are the maximum tolerated.

TABLE XVII

Histamine content of tissues of mice following treatment with 48/80 over 31 days (Long-term experiment)

Values expressed in $\mu g . / g$. tissue

\begin{tabular}{|c|c|c|}
\hline Day & $\begin{array}{c}\text { Subcutaneous } \\
\text { connective tissue }\end{array}$ & Ears \\
\hline 0 & 28 & 50 \\
3 & 24 & 30 \\
8 & 25 & 28 \\
15 & 15 & 25 \\
21 & 14 & 25 \\
32 & 18 & 25 \\
\hline
\end{tabular}

\section{DisCUSSION}

The above experiments indicate that the same chemical substance, compound $48 / 80$, acts differently on two closely allied species, the mouse and rat. 
Histamine-liberation and disruption of mast cells play a comparatively small part in the overall action of the liberator in the mouse, other toxic factors being more prominent. In the rat, on the other hand, compound 48/80 appears to exert a selective action on the mast cells. There are no other toxic side-effects, oedema from the action of the locally released histamine and local irritation of the skin being the prominent features. In the mouse, oedema and scratching

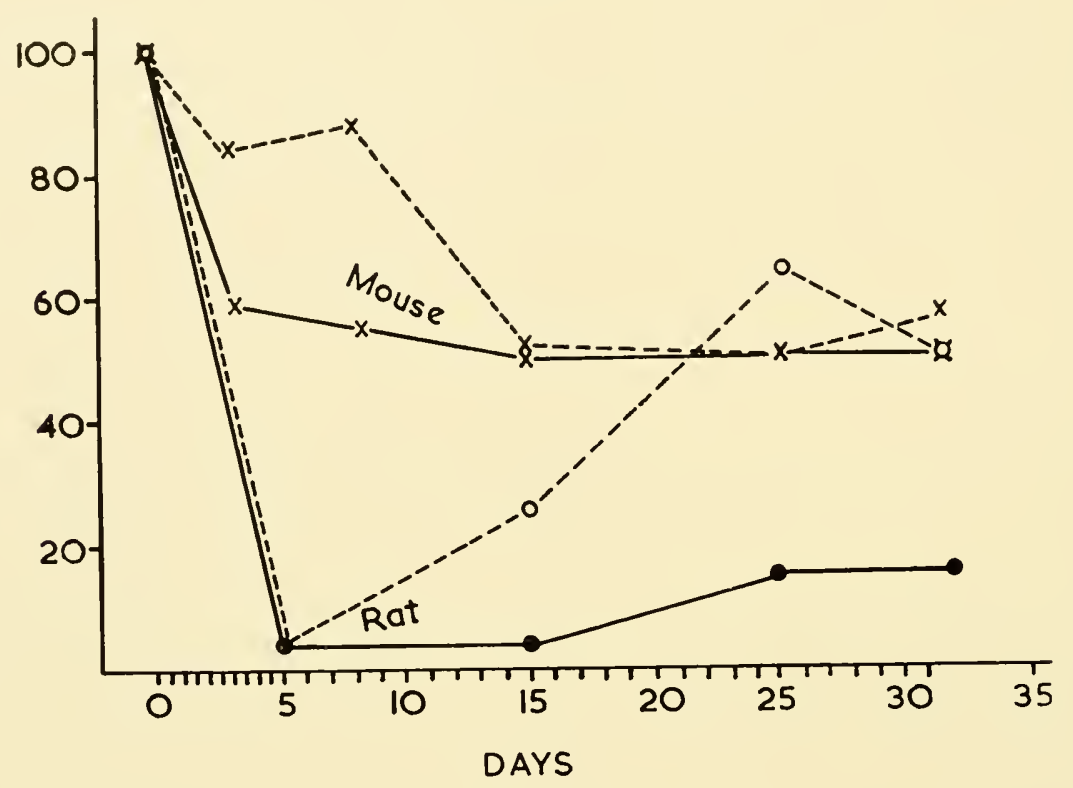

FIG. 42

Long-term experiment. Effect of compound 48 ' 80 , continued over thirty-one days, on the histamine content of subcutaneous connective tissue (dotted lines) and ears (solid lines) of mouse and rat: histamine values expressed as per cent of normal. Despite the repeated daily dosage not more than about half the available histamine can be liberated from the mouse. Full depletion in the rat is followed by some recovery in the subcutaneous connective tissue but not in the ears.

are never more than slight and may sometimes be absent. Biological assay confirms that proportionately less histamine is released in the mouse despite maximum tolerated doses of the liberator (amounting to $15 \mathrm{mg}$. $\mathrm{kg}$.) being administered.

In the long-term experiments a state is reached in which most tissues of the rat are completely devoid of both mast cells and histamine; further injections now fail to elicit the clinical signs of histamine release. With continued dosage some recovery of histamine and mast cells occurs in the subcutaneous connective tissue of the rat but not in the ears. In the mouse under prolonged dosage of compound $48 / 80$, a steady state is reached when only about half of the histamine 
in the tissues has been liberated. Further injections are toxic for reasons which are not yet clear.

It is evident, therefore, that no simple hypothesis is adequate to explain the action of compound 48,80 as a liberator of histamine. Compelling evidence has been presented earlier that the chief repository of the tissue histamine is the mast cell: this would appear to be true for all species. On the other hand, compound 4880 , which is so effective in the rat, is only a moderately successful liberator of histamine in the mouse, and can hardly be described as a histamineliberator for the guinea pig in which other toxic symptoms predominate (Feinberg and Sternberger, 1955).

The solution of one problem only brings others to light. It would seem that the next step is to enquire more closely into the structure and composition of the mast granule in various species and the means whereby histamine is bound in the cell. This may suggest a basis for the mechanism of its release. 


\section{BINDING OF HISTAMINE IN THE MAST CELL: THE NATURE OF THE MAST-CELL GRANULE}

\section{$\mathrm{H}$} EPARIN is an acid, histamine a base: is the mast-cell granule then a salt-like compound, a 'heparinate of histamine'? The simple explanation is attractive (Mota et al, 1953; Smith, 1958); yet if the two substances can combine in the cell, why do they remain apart in the blood, as they appear to do in the dog's blood during peptone shock? And how can we explain the different effects of the same histamine-liberator on the mast cells of different species (Feinberg and Sternberger, 1955), or at different sites in the same individual (Nishiyama et al, 1957)?

It was formerly believed-and until very recently was still believed by Rocha e Silva (1955) - that histamine is firmly bound to some tissue component as the amino-acid histidine, which is split off and decarboxylated when histamine is released into the blood. The exact binding site was never precisely defined, though it was suggested that the histidine might occupy a terminal position in a protein or polypeptide chain. In this view, histamine-release involves both a proteolysis and a decarboxylation.

Now that we have tracked down the histamine to its depots in the tissue mast cells, we are better placed for examining both the mode of its binding and the mechanism of its release. Indeed, I believe that the experiments, previously described, on the visible effects of the fluorescent diamidines on the tissue mast cells of the rat represent the first real evidence for the intracellular location of tissue histamine and its release by a chemical agent.

\section{Effect of $p H$}

However, it may be argued that if histamine and heparin do co-exist in loose ionic linkage by virtue of their opposite electrical charges, it should be possible to separate them by subjecting the combination to a greater potential difference-an electrophoresis in vivo. The following experiment was therefore devised (Fig. 43).

A fresh loop of rat small intestine with its attached mesentery is spread on a warm microscope slide and one of the avascular interspaces (a peritoneal 'window') is covered with a drop of normal saline at body temperature. Two platinum wire electrodes, bent as shown, are placed about $1 \mathrm{~cm}$. apart on either side of a suitable microscope field containing numerous mast cells; the electrodes are in turn connected through a switch to a 12-volt accumulator. A fragment 
of cover slip is lowered on to the field which is to be observed, the microscope re-focused and the switch closed.

For a moment nothing happens. Then, one after another the mast cells 'tense', round up and, literally, explode-a most dramatic and astonishing sight. However, it was quickly evident that this is not an 'electrophoretic' separation: the 'explosions' begin at the cathode, spread to the centre of the

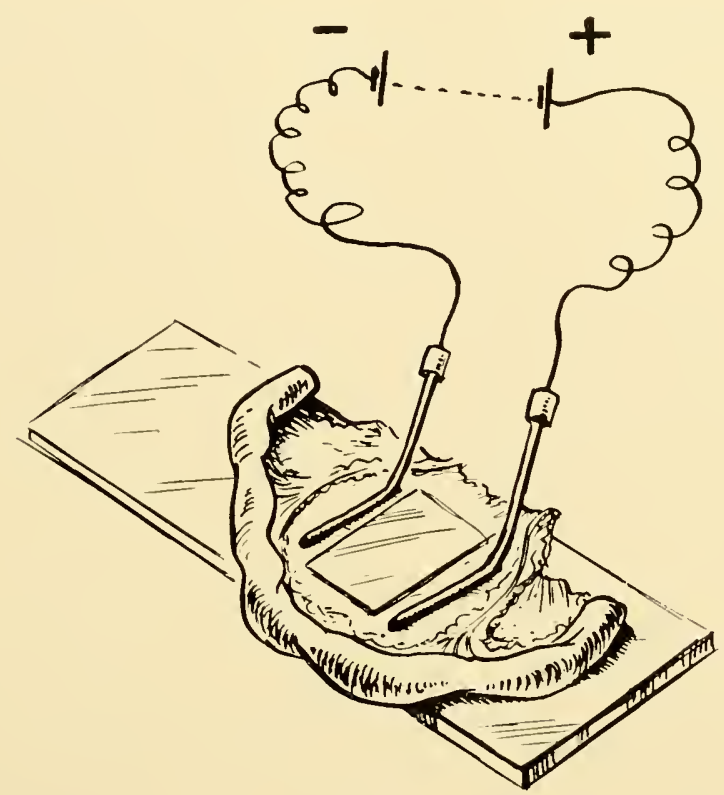

FiG. 43

Simple apparatus for testing the effect of an electrical field on mast cells in rat mesentery. The preparation is bathed in physiological salt solution.

field and stop (Fig. 44). By replacing the tissue with a piece of filter paper soaked in a dilute solution of an indicator fluid ('Universal Indicator', B.D.H.) it is evident that the origin and extent of the disruption of the mast cells correspond exactly to the wave of sodium hydroxide which is released electrolytically from the salt solution in which the preparation is bathed; this also begins at the cathode and stops at the centre of the field. The mast cells near the positive pole, the acidic $(\mathrm{HCl})$ half of the field, remain intact. If the current is reversed they, too, undergo disruption. The whole phenomenon can be reproduced by running a drop of $\mathrm{N} / 10$ sodium hydroxide under the cover slip of a fresh preparation (Fig. 45). 
This experiment led naturally to a consideration of the effects of bases in general on mast cells, from which the general conclusion was drawn that any change in the $p \mathrm{H}$ of the surrounding medium from neutrality towards the alkaline side favours the swelling and disruption of the tissue mast cells. Ammonia, the simplest of amines, is at least as effective (though less specific) than the complex organic bases studied by MacIntosh and Paton (Schild, 1949).

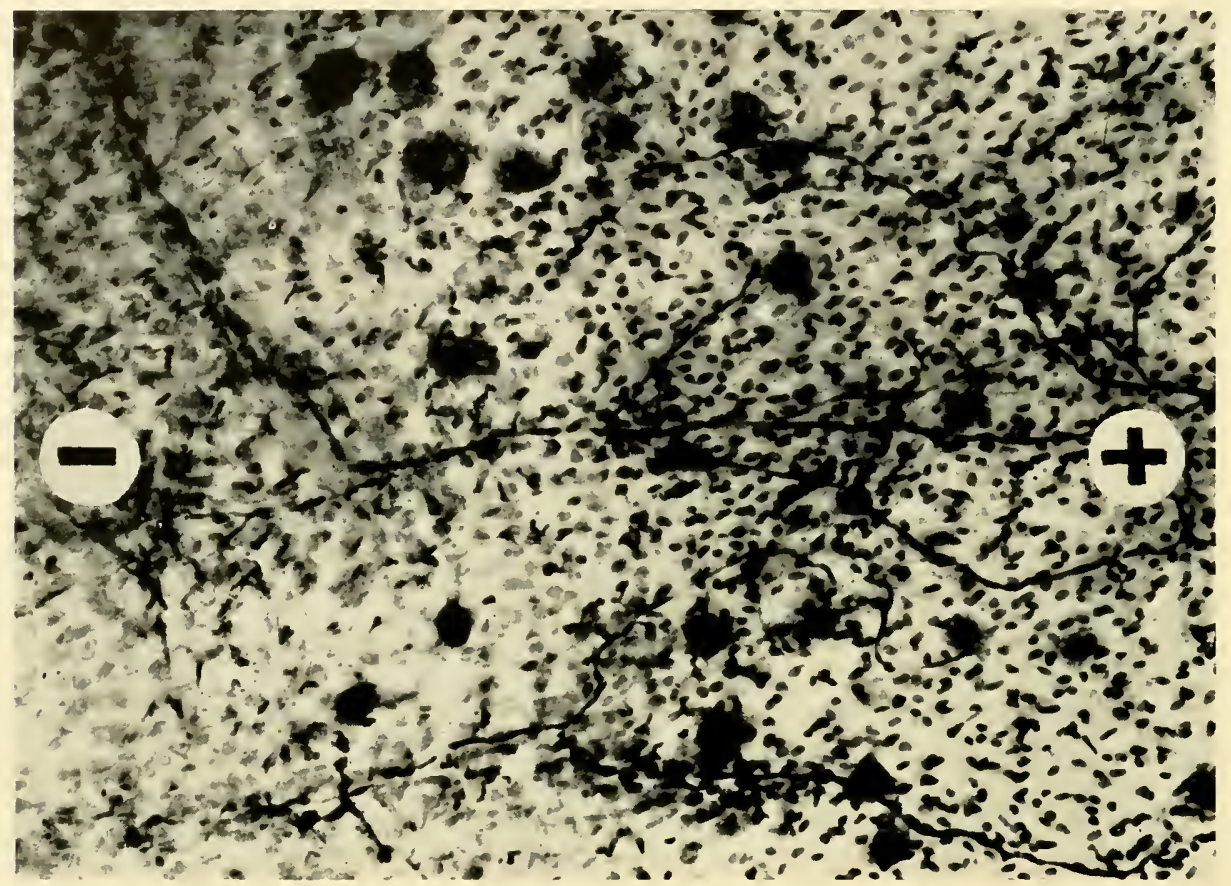

FiG. 44

On closing the circuit a wave of 'exploding' mast cells spreads from the negative pole to the centre of the field, and stops. If the current is reversed the remaining half of the field is similarly affected.

The violent disruptive effect of ammonia on the mast cells was demonstrated in vivo by exteriorizing a loop of small intestine from a rat under Nembutal anaesthesia and spraying the peritoneal window with warm ammonia vapour. Here the disruption of the living mast cells can be seen under the microscope (Fig. 46). Such a preparation can be used for examining the effects of the less toxic liberators, applied topically or injected intravenously into the rat.

Two small series of animals were given intraperitoneal injections of sodium hydroxide, or ammonium hydroxide (West, 1956) and estimations were subsequently made of the tissue histamine, as in the previous work in which compound 4880 was used. The results are recorded in Tables XVIII and XIX. 


\section{TABLE XVIII}

Effect of 4 intraperitoneal injections of $\mathrm{M} \mathrm{NH} \mathrm{H}_{4} \mathrm{OH}$ on the histamine content ( $/ \mathrm{g} . / \mathrm{g}$.$) and mast-cell content of tissues of rats (4 per group)$ at various times after injection

\begin{tabular}{|c|c|c|c|c|c|c|}
\hline \multirow{2}{*}{ Day } & \multicolumn{2}{|c|}{$\begin{array}{l}\text { Subcutaneous } \\
\text { connective tissue }\end{array}$} & \multicolumn{2}{|c|}{ Omentum } & \multicolumn{2}{|c|}{ Mesentery } \\
\hline & $\begin{array}{l}\text { Hist- } \\
\text { amine }\end{array}$ & $\begin{array}{l}\text { Mast } \\
\text { Cells }\end{array}$ & $\begin{array}{l}\text { Hist- } \\
\text { amine }\end{array}$ & $\begin{array}{l}\text { Mast } \\
\text { Cells }\end{array}$ & $\begin{array}{l}\text { Hist- } \\
\text { amine }\end{array}$ & $\begin{array}{l}\text { Mast } \\
\text { Cells }\end{array}$ \\
\hline 0 & 32 & ++ & 18 & ++ & 12 & ++ \\
\hline 3 & 28 & ++ & 1 & 0 & 4 & + \\
\hline 11 & 30 & ++ & 11 & + & 6 & + \\
\hline 22 & 32 & ++ & 16 & ++ & 12 & ++ \\
\hline
\end{tabular}

TABLE XIX

Effect of 4 intraperitoneal injections of $\mathrm{N}^{\prime} 10 \mathrm{NaOH}$ on the histamine content $(\mu \mathrm{g} . \mathrm{g}$.) and mast-cell content of tissues of rats (4 per group) at various times after injection

\begin{tabular}{|c|c|c|c|c|c|c|}
\hline \multirow{2}{*}{ Day } & \multicolumn{2}{|c|}{$\begin{array}{l}\text { Subcutaneous } \\
\text { connective tissue }\end{array}$} & \multicolumn{2}{|c|}{ Omentum } & \multicolumn{2}{|c|}{ Mesentery } \\
\hline & $\begin{array}{l}\text { Hist- } \\
\text { amine }\end{array}$ & $\begin{array}{l}\text { Mast } \\
\text { Cells }\end{array}$ & $\begin{array}{l}\text { Hist- } \\
\text { amine }\end{array}$ & $\begin{array}{l}\text { Mast } \\
\text { Cells }\end{array}$ & $\begin{array}{l}\text { Hist- } \\
\text { amine }\end{array}$ & $\begin{array}{l}\text { Mast } \\
\text { Cells }\end{array}$ \\
\hline 0 & 28 & +4 & 16 & ++ & 10 & ++ \\
\hline 3 & 28 & ++ & 1 & 0 & 4 & + \\
\hline 11 & 34 & ++ & 10 & + & 5 & + \\
\hline 22 & 32 & ++ & 12 & ++ & 10 & ++ \\
\hline
\end{tabular}

However, histological examination confirmed that in addition to the destruction of the mast cells there was also a gross inflammatory reaction in the neighbouring tissues. There were no changes in mast cells or in the histamine contents of tissues remote from the peritoneum. As with compound 4880 , the histamine values fell and were restored in parallel with the disappearance and reappearance of the mast cells, but there was nothing specific in the effect. While these experiments thus show that a binding between histamine and heparin can occur at low $p \mathrm{H}$ (Werle, 1955; Keller, 1958), it is unlikely that a specific histamine-liberator acts merely by neutralizing the charge on the heparin moiety. A more complex mechanism is to be anticipated.

\section{Effect of water}

Of greater interest perhaps is the effect of water, without the addition of any chemical liberator, in releasing tissue histamine (Hagen, 1954; Grossberg and Garcia-Arocha, 1954). 
THE MAST CELLS

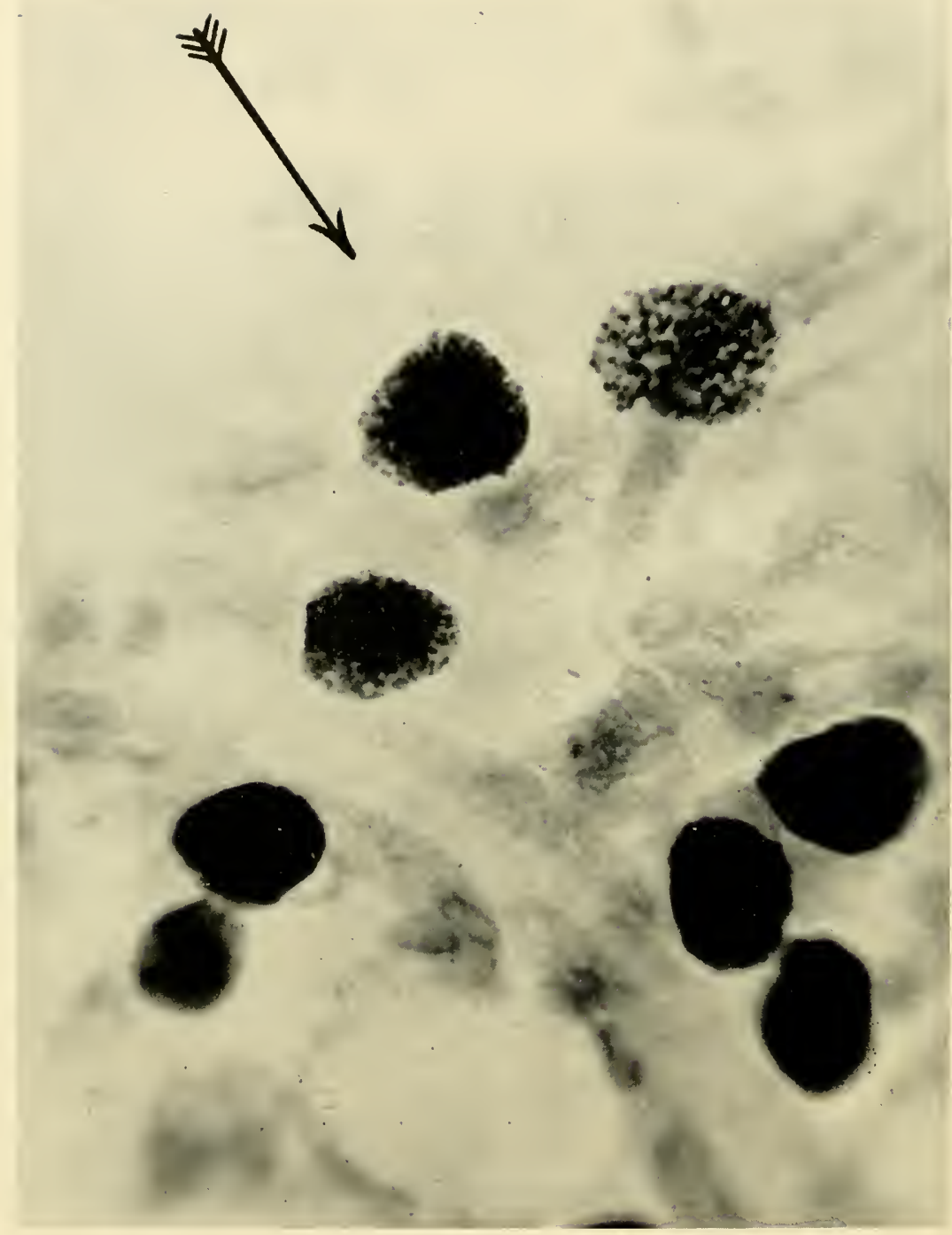

FIG. 45

The "explosions" are due to the action on the mast cells of sodium hydroxide, liberated at the cathode. Here a weak solution of sodium hydroxide (arrow) is being run under the cover-slip of a fresh preparation. Note swelling and disruption of the mast cells, as before $(\times 950)$. 


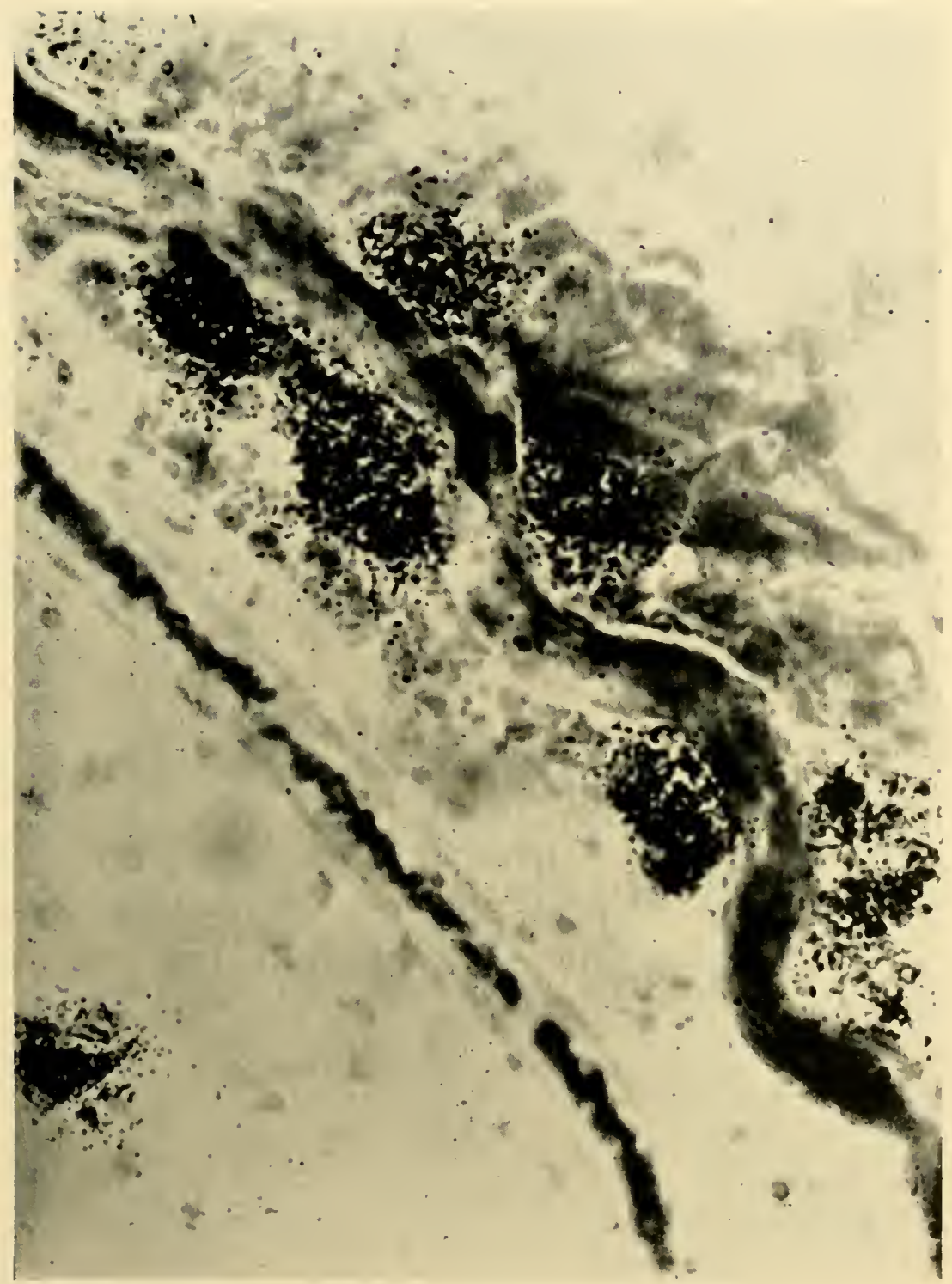

FIG. 46

Ammonia, the simplest of amines, is an efficient though non-specific histamineliberator. Living mast cells in this preparation of exteriorized rat mesentery have been sprayed with ammonia vapour, then fixed and stained as a tissue spread. The swelling and disruption of the mast cells are clearly visible $(\times 700)$. 
It has been known since the time of Ehrlich and Westphal that the mast cells in certain species are extremely susceptible to the action of water; hence water is a histamine-liberator for these species. When the tissues are stored under more physiological conditions, as in balanced salt solution, the mast cells survive longer and the histamine value of the tissue is sustained. This is illustrated in Table XX in which histamine values were recorded for strips of fresh sheep liver capsule, taken from the same animal, and immersed for one hour in water, normal saline or a dilute solution of the histamine-liberator D-tubocurarine.

\section{TABLE XX}

Effect of water, sodium chloride solution $(0.9$ per cent $w / v)$, and solution of D-tubocurarine $(0 \cdot 1$ per cent $w / v)$ on the histamine content $(\mu \mathrm{g} . / \mathrm{g}$. tissue) and mast-cell content of sheep-liver capsule. Immersion time, $1 \mathrm{hr}$. at room temperature

\begin{tabular}{|c|c|c|}
\hline Liberator & Histamine & Mast Cells \\
\hline None & 40 & ++ \\
\hline Normal saline & 35 & ++ \\
\hline Water & 25 & + \\
\hline D-tubocurarine & 14 & + \\
\hline
\end{tabular}

The mast granules in excised tissues of the rat are comparatively resistant to osmotic disruption by water (Paff and Mergenthaler, 1955). Nevertheless, as Fawcett (1954) has shown, the repeated intraperitoneal injection of comparatively large volumes of water into the living rat removes, almost selectively, the mast cells from the peritoneum; meanwhile the histamine is released into the water and can be assayed. The corollary experiment can then be performed: a subsequent injection of compound 4880 fails to release more histamine, its target, the mast cells, having already been destroyed.

The effects of water on the mast cells can be conveniently followed under the microscope. If a fresh tissue spread containing mast cells, such as a piece of ox peritoneum, is placed on a warm slide and covered with a drop of water containing a little dilute toluidine blue, the whole interaction of water with the mast cell can be observed. At first the dye is concentrated exclusively in the granules, though not all the granules stain simultaneously, even in the same cell. As staining takes place the colour of the dye changes from blue to purple or even to red (metachromasia). It is a little difficult to reconcile this observation with the view still held by Sylvén (1957) that the metachromatic material is normally located in the intergranular cytoplasm and that its presence in, or on, the granules is an artefact (Julen et al, 1949). It has long been known that scattered granules still stain metachromatically. Next, both cell and granules 


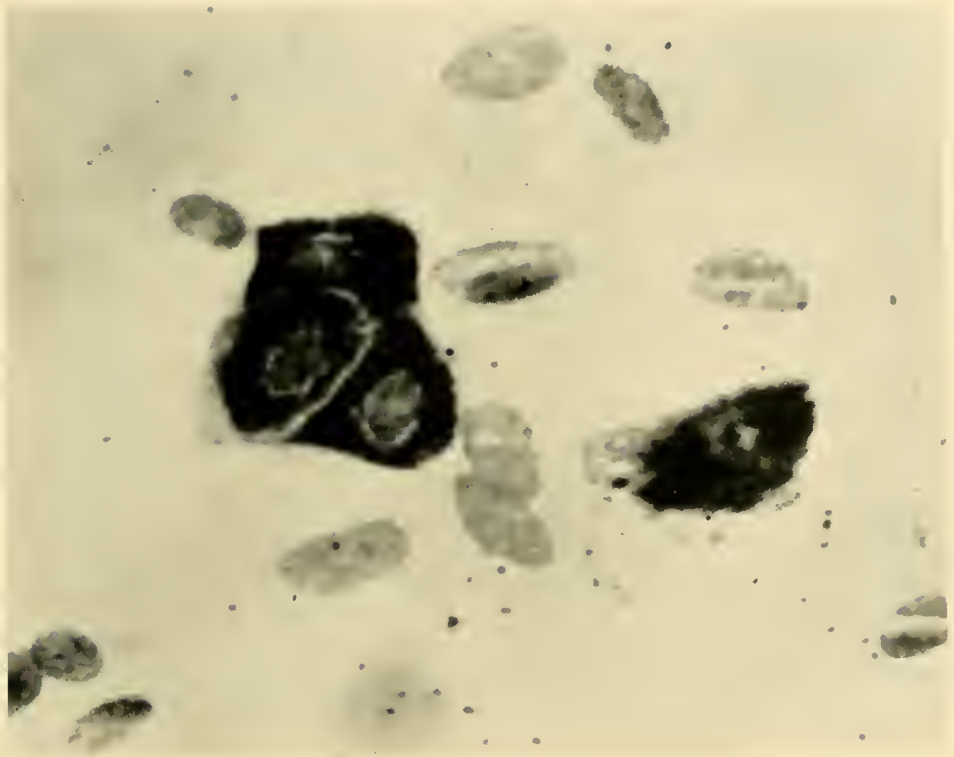

FIG. 47

Mast cells in a fresh spread of ox peritoneum; fixed alcohol, stained toluidineblue. The cytoplasm is packed with dark metachromatic granules $(\times 535)$. (Riley (1954), Lancet, p. 841.)

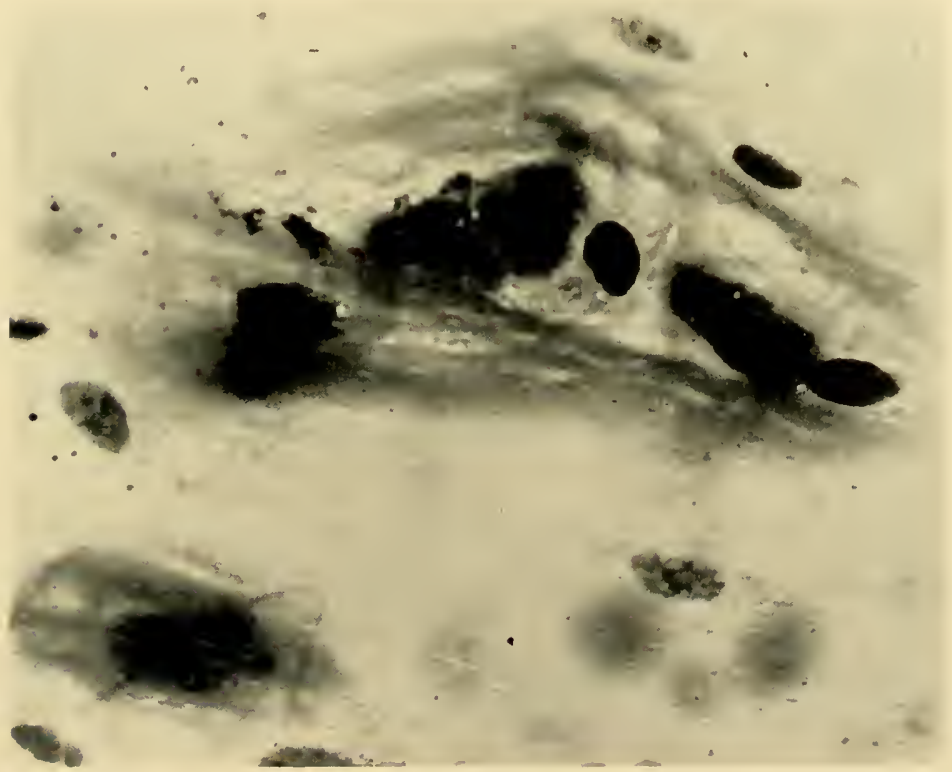

FIG. 48

A part of the same tissue spread as in Fig. 47. This area was dipped in water before being fixed with alcohol. There is now disruption of the mast cells; their nuclei stain darkly; and much of the metachromatic material has diffused out of the cells and become attached to adjacent connective tissue fibrils $(\times 535)$. (Riley (1954), Lancet, p. 841.) 
begin to swell and metachromatic material can now be seen to diffuse from the granules into the cytoplasm and, ultimately, through the cell wall to form a pericellular metachromatic halo. The exceedingly thin cell wall may rupture, leaving behind only a few swollen and usually basophilic granules and a nucleus now also swollen and stained. These findings were, in fact, known to Ehrlich (1878), as we can very well appreciate now that his own thesis is available for consultation (1956). Ehrlich believed the nuclear staining to be due to the formation of a double salt. It seems likely that the heparin penetrates the nucleus of a dead cell and there combines with its basic protein, forming a stainable complex (Figs. 47-50). Sometimes the diffuse pericellular metachromasia can be seen to concentrate around, and become attached to, adjacent connective tissue fibrils (Riley, 1954, 1956, p. 400; and see Figs. 47 and 48).

However, if the dye is applied to the mast cell, not in water but in normal saline or Ringer-Locke solution, the granules stain successively as before but now appear to be preserved rather than destroyed by the dye. Following this lead, I tested the effects of adding the dye toluidine blue to an intraperitoneal injection of saline in the rat. To all outward appearances the mast cells and their granules seemed well preserved when fresh tissue spreads were examined at the end of the experiments. There was neither degranulation nor disruption. Yet, as in Fawcett's experiment, histamine had been released into the surrounding fluid. Presumably one amine (the dye) had replaced the other (histamine). This process may perhaps occur under yet more physiological circumstances: thus Feldberg and Smith (1953) showed that tryptamine and 5-hydroxytryptamine can act as histamine-liberators in vivo. One might speculate that the traces of 5-HT which are normally found in the mast cells of the mouse and rat (Benditt et al, 1955; West and Parratt, 1957) have reached the cells in this way.

The above findings thus draw attention to the complexity of the mast-cell granule. Heparin, in common with other electro-negative colloids, can be stored as droplets in cells of the reticulo-endothelial system (Asplund et al, 1939); but these are not mast cells (Isidor, 1954). The granules in young mast cells in the rat tend to be basophilic with toluidine blue and stain positively with the periodic acid-Schiff method (Jorpes et al, 1948), whereas the more mature granule is metachromatic and PAS-negative (Riley, 1953a). Mast cells also rapidly incorporate and store labelled sulphate (Jorpes et al, 1953). These findings certainly suggest that at least a final rearrangement and sulphation of the heparin molecule occurs inside the mast cell. Somewhat similar considerations apply to the histamine and 5-hydroxytryptamine in mast cells. Thus, Schayer (1956) has shown that a suspension of rat mast cells can take up labelled histidine from the medium and convert it into labelled histamine. According to Lagunoff et al (1957) and Hagen and Lee (1958) the mast cells 
in the skin of both rat and mouse can convert 5-hydroxytryptophan into 5-hydroxytryptamine. The work of Riley and Drennan (1949), Friberg et al (1951), Wislocki and Fawcett (1951), Compton (1952), Montagna et al (1946, 1948, 1954), Montagna (1957) and others have extended the histochemical observations of Noback and Montagna (1946) on the complex structure and enzyme content of the granules. Zollinger (1950), for example, has likened the granules to 'giant mitochondria'. However, recent studies with the electron microscope (Bloom and Friberg, 1953; Bloom et al, 1955; Smith and Lewis, 1955; Stoeckenius, 1956; Rogers, 1956) confirm that the mast cell usually contains a few typical mitochondria in addition to its vast complement of large granules (Nakajima, 1928). Indeed, recent biochemical evidence supports the view that it is the large granule which contains the histamine (West, 1955), heparin (Köksal, 1953) and 5-hydroxytryptamine (Barrnett et al, 1958). The inter-relationship, if any, of the two types of cytoplasmic inclusion has yet to be determined. Hence it is clear that the mast-cell granule is more than a mere chemical polymerization of heparin, or even of heparin and histamine: it is a metabolically active organelle which responds to changes in its environment as an intracellular osmometer, and, acting in this way, is capable of liberating its contents.

\section{Effect of trichloracetic acid (See West and Riley, 1954)}

Trichloracetic acid is so efficient, and acts so rapidly, in extracting histamine from a tissue rich in mast cells that it seemed worth while to examine more closely its mode of action. In the first place, the very fact that trichloracetic acid is so efficient in withdrawing histamine from its depots, seriously impairs any hypothesis that histamine must first be formed enzymatically from histidine in protein before it can be released into the body fluids. Trichloracetic acid precipitates protein and thus inhibits enzymic action; and the fact that water is itself an efficient histamine-liberator adds further to the present belief that the histamine already exists, preformed, in the mast cell, held only by loose ionic linkages.

In order to obtain information about the action of trichloracetic acid, suitable tissue extracts were subjected to chromatographic analysis.

Extracts of tissues exceptionally rich in histamine, such as ox pleura, ox liver capsule, and mast-cell tumours from dogs, were prepared for ascending chromatographic estimation of histamine by simple extraction or by grinding the tissues with 10 per cent aqueous trichloracetic acid and centrifuging. Using as solvent mixture $n$-butanol : acetic acid : water $(4: 1: 5)$, it was observed that after spraying with the Pauly or the paranitraniline diazo-reagent not one, but two, sharply defined spots appeared on the chromatogram of $R_{F}=0.11$ and 0.65 . Both spots contained material which when eluted with water or 0.01 
$\mathrm{N}$ hydrochloric acid showed histamine activity on the isolated guinea pig ileum and on the blood pressure of the atropinized cat. Prior removal of the excess trichloracetic acid from the solution by ether extraction merely reduced the intensity of the fast-running spot. When an eluate of this fast-running spot $\left(R_{F}=0.65\right)$ was re-run in the same solvent as before, the histamine now remained entirely in its lower location $\left(R_{F}=0 \cdot 11\right)$.

Further experiments showed that at least three factors are involved in the migration of histamine to the fast-running spot, namely: (1) the concentration of trichloracetic acid; (2) the concentration of histamine; (3) the presence of a basic amino-acid. First, pure histamine acid phosphate in water forms a compact spot at $\mathrm{R}_{\mathrm{F}}=0 \cdot 11$, but with increasing concentration of trichloracetic acid a "trail ' of histamine moves up the paper as far as the $R_{F}=0.65$ area. This is not a mere $p \mathrm{H}$ effect, for histamine in $0.33 \mathrm{~N}$ hydrochloric acid or in 10 per cent aqueous acetic acid does not migrate in this way. Trifluor-acetic acid resembles trichloracetic acid in its mobilizing effect on histamine, recalling the similar effect of these acids on the chromatographic behaviour of adrenaline (Shepherd and West, 1952). Removal of the excess acid from these solutions by ether extraction concentrates the histamine into a single compact spot at $\mathrm{R}_{\mathrm{F}}=0 \cdot 11$. Secondly, when the strength of the trichloracetic acid is kept constant, any increase in concentration of histamine in the mixture is followed by increased upward trailing from the slow-running spot. Thirdly, for complete separation of the two spots, the presence of at least one basic amino-acid is necessary. Thus, when an artificial mixture is made up containing pure histamine, trichloracetic acid and arginine, lysine or ornithine, the chromatographic pattern now exactly resembles that seen with tissue extracts, the histamine being divided between the two spots, $R_{F}=0.11$ and $R_{F}=0.65$; ether extraction of this mixture simply reduces the intensity of the fast-running spot. When all three amino-acids are present in the mixture, the chromatogram shows inversion, only the upper (fast-running) spot now appearing on the paper.

It is thus possible that the remarkable ability of trichloracetic acid to extract histamine from tissues is related not only to its coagulative effect on protein but also to its participation in a loose complex containing histamine (probably as the trichloracetate) and basic amino-acids. Detailed analysis of the original tissue chromatogram shows that arginine and lysine are in fact present and trail behind the fast-running spot of histamine.

\section{Phospholipid content}

The hydration of the mast granule by water, and especially by water containing alkali, invites comparison with other biological systems which react in similar fashion. Among these, the curious formation of 'myelin figures' by the fatty material of nerve sheaths or by the lipoidal walls of plant cells and 
plastids (Gicklhorn, 1932) is outstanding. There is now abundant evidence (cf. Frey Wyssling, 1948) that such structures are composed mainly of bimolecular leaflets of phospholipid, often cross-linked by divalent calcium ions, and that mild saponification by alkali is sufficient to admit water between the leaflets and so produce visible swelling and the emergence of strange, worm-like tubes as the process of hydration travels through the system. Nils Berg (1951) using benzpyrene-caffein as a 'stain' followed by examination of the preparation in ultra-violet light for the detection of fluorescent lipoids has shown that both nerve sheaths and mast-cell granules 'stain' positively for phospholipids which, in the natural state of the tissues are either so finely dispersed or so tightly bound to protein that they fail to stain with conventional methods. Hedbom and Snellman (1955) isolated the mast granules from the cells in ox liver capsule and subjected them to various analytical procedures. They state that the lipid fraction comprised no less than 23.9 per cent of the total dry weight and that (p. 154) 'the main part of the lipid fraction was not soluble in acetone, which indicated a high percentage of lecithin'. It is, of course, the lecithin which is believed to provide the physical basis for the hydration of the myelin in nerve sheaths and plant cells. On the other hand, as we have observed earlier in a study of the effects of compound $48 / 80$ on the rat, the nerve sheaths appear to be among the tissues in the skin which are not affected by compound 48/80: even the mast cells within the nerve sheaths remain intact. A more subtle mechanism is required to explain how histamine-release is 'triggered' in the mast cell.

Seeking another component of the mast granule which might respond either to the effects of a histamine-liberator, or even to the released histamine itself, my attention was caught by a report of some physico-chemical experiments on artificial surface films, carried out by Dr. R. Hirt in Bern. Briefly, Hirt and his colleagues (1952) were able to show by a tensiometric technique,

that a primary (but not a secondary), phosphatide of the type $\mathrm{R}^{\prime}-\mathrm{O}-\mathrm{P}-\mathrm{OH}$

$\mathrm{OH}$

reacts specifically with histamine, as is shown by a sudden and decisive drop in the surface tension of the film at a liquid-liquid interface when histamine is applied. Further, the film can be protected by pre-treatment with an antihistamine drug. It will be recalled that I found that the injection of mepyramine into a rat shielded its mast cells against the disruptive action of stilbamidine, despite the fact that the diamidine still reached the cells, as shown by their vivid fluorescence in ultra-violet light.

A preliminary investigation has therefore been started in co-operation with Dr. R. M. C. Dawson of Cambridge who has made a detailed study of the 
phosphatidic acids and their identification in biological material. Various tissues, rich in mast cells, have been sent to Dr. Dawson, either in 1:1 chloroform methanol or after preliminary hydrolysis, and he has chromatographed them against known standards (Dawson, 1957). A special effort was made to obtain a reasonably pure sample of isolated mast-cell granules from the rat by taking advantage of the fact that the granules in this species are remarkably resistant to the lytic action of water (Paff and Mergenthaler, 1955).

Ten adult Wistar rats were killed by a blow on the head, skinned, and the subcutaneous connective tissue was vigorously scraped off with a scalpel. Representative samples of this were made into tissue spreads and stained with toluidine blue and the remainder was then immersed in a stoppered bottle of water and agitated at maximum speed for one hour in a mechanical shaker. Tissue spreads prepared from the residue showed that a high proportion of the mast cells had been disrupted and their granules scattered (Figs. 49 and 50). The rest of the tissue pulp was strained through glass wool and the turbid filtrate centrifuged. Examination of a smear of this deposit stained with toluidine blue on a microscope slide, disclosed that it consisted mainly of mast granules with a few nuclei. Chromatography of a hydrolyzed sample indicated that the mast granules of the rat contain lecithin (phosphatidyl choline) and phosphatidyl ethanolamine and are curiously rich in phosphatidyl serine, a phosphatide which Kirschner (1957) has recently suggested may participate in active sodium transport across the erythrocyte membrane. Other mast cellrich tissues which we have so far examined for phospholipids include portions of a mouse mastocytoma (obtained through the kindness of Dr. Jacob Furth, in Boston) and a specimen, believed to be a mastocytoma, from a cow. All were found to contain phosphatidyl choline and appreciable amounts of phosphatidyl serine, though in somewhat lower concentration than in mast granules isolated from the connective tissue of rats.

\section{CONCLUSIONS REGARDING THE BINDING OF HISTAMINE IN THE MAST CELL}

All the above observations are compatible with the belief, previously expressed in this book, that the older views on 'bound' and 'free' histamine are no longer tenable now that the intra-cellular location of tissue histamine in the mast cell is known, and the site of its binding can be more critically examined. The present work suggests strongly that much of the histamine in a tissue is present in its mast cells, preformed and ready for release by any agent which will disrupt the mast cell (water, alkali, trauma) or, more subtly, by the somewhat heterogeneous group of 'histamine-liberators'. Very recently Archer (1958) has described an endogenous histamine-liberator which may play a vital role in the release of histamine in the inflammatory process. Knowledge 


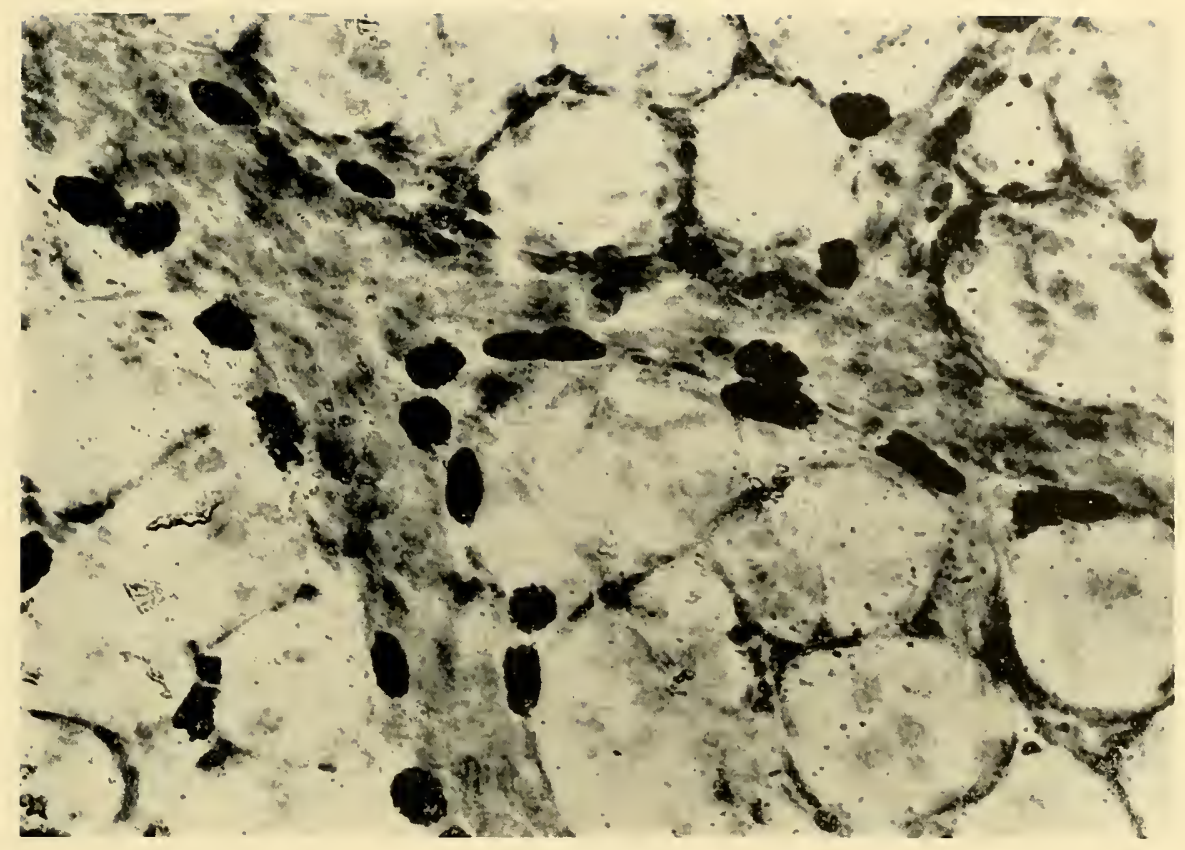

FIG. 49

Control tissue spread, rat subcutaneous connective tissue. Toluidine blue ( .320$)$.

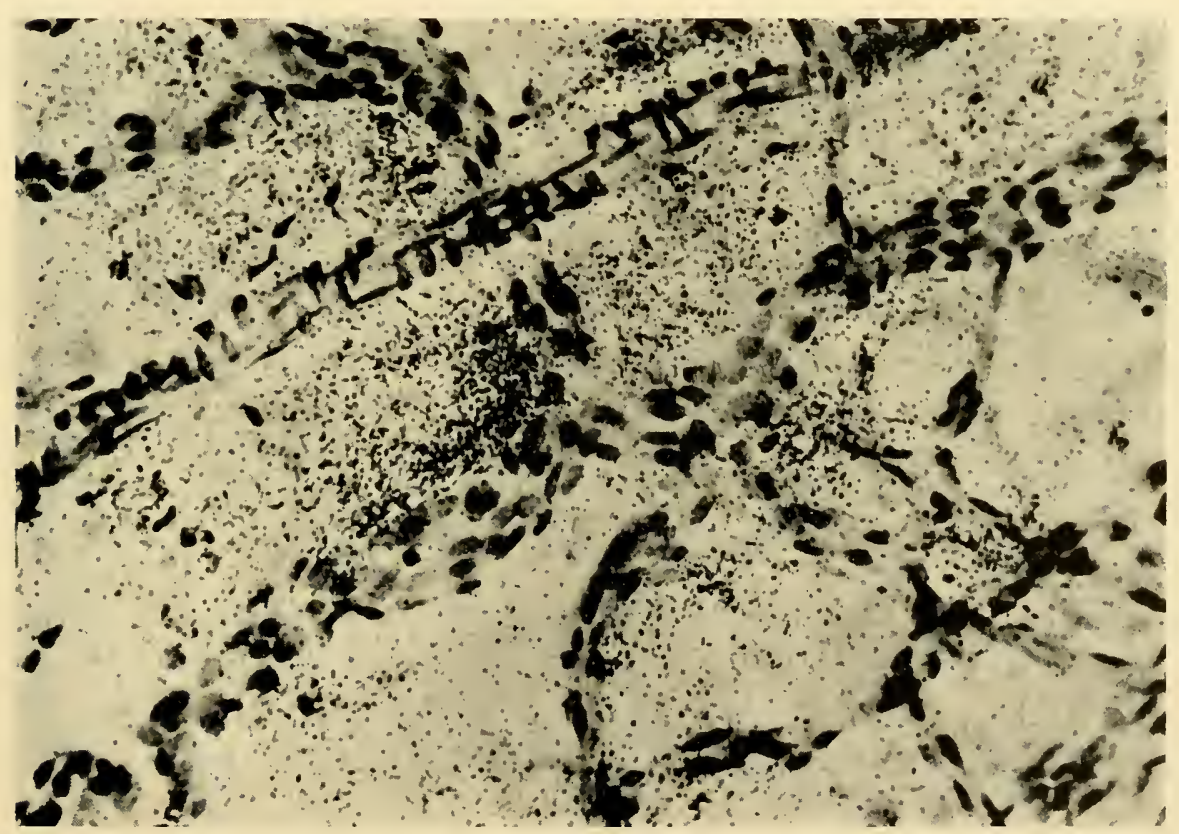

FIG. 50

Tissue spread, rat subcutaneous connective tissue following vigorous shaking in 25 per cent sucrose for two hours. Only a few scattered granules remain at the site of the mast cells. Note also that the endothelial nuclei now stain with toluidine blue $(\times 320)$. 
of the mast cell and the structure of the mast granule suggests a multiplicity of mechanisms whereby histamine may be released. These range from the total disruption of the mast cell to the quiet replacement of the histamine molecule by another amine (as, for example, toluidine blue) without accompanying morphological change. The reader is referred to the excellent reviews by Paton $(1955,1957,1958)$ on the structure-action relationships of the many histamine-liberators which are now known. Finally, there is evidence, admittedly as yet fragmentary, that the granule or cell membrane may contain in its structure a phospholipid capable of yielding a primary phosphatide selectively sensitive to histamine, which, freed from its ionic linkage in the cell, procures its own release by its surface activity on the film which surrounds it. This may prove to be the point of attack of the chemical histamine-liberators.

This last-mentioned hypothesis has recently received considerable experimental support from the work of Uvnäs (Högberg and Uvnäs, 1957; Uvnäs, $1958 a$ and $b$ ) in Stockholm who suggests that a basic histamine-liberator such as compound $48 / 80$ releases histamine from the mast cell, not by a mere neutralization of acidic heparin in a histamine-heparin complex, but by removing an inhibitor from a lecithinase situated at the mast-cell membrane. The activated enzyme then brings about a lysis of the cell envelope, so permiting the intracellular histamine to escape (Högberg and Uvnäs, 1958).

I had myself considered the possible role of a lecithinase in the process of histamine-release from mast cells (Riley, 1958a) but had failed to envisage the necessary mechanism whereby a chemical histamine-liberator might influence an enzymic process. However, if we not only accept Uvnäs' hypothesis but make the additional assumption that the enzyme is a Type-C lecithinase (Deuel, 1951), attacking the ester link between the phosphoric acid and the alcohol, we infer that its action on the various phospholipids demonstrated by Dr. Dawson in mast cells would be as follows:

Phosphatidyl choline yields a primary phosphatide and choline Phosphatidyl serine yields a primary phosphatide and serine

Phosphatidyl ethanolamine yields a primary phosphatide and ethanolamine.

From each, therefore, there is formed first, a primary phosphatide selectively permeable to histamine (Hirt and Berchtold, 1952) and second, an alcohol (choline, serine, ethanolamine) differing quantitatively and qualitatively from one type of mast cell to another. When the effects of the three alcohols are tested on mast cells in fresh tissue spreads of rat mesentery, it is immediately apparent that ethanolamine is the most effective disrupter of mast cells and, in fact, produces a frothy, 'honeycomb' appearance of the cytoplasm very similar to that which is observed in vivo (Riley, 1953b; Hill, 1957). 


\section{COMPOUND $48 / 80$ ON RAT}

It is as yet too soon to judge the merit of this new approach to the problem of the release of histamine from mast cells by the chemical histamine-liberators; its value is rather that it opens up the way to fresh experimentation. As mentioned earlier, it is certainly not necessary that either degranulation or disruption occur for histamine to escape from the mast cell. The chemical liberators are associated with pathological events.

Important as the mast cell may be in accounting for the bulk of tissue histamine, it is desirable that we should next enquire whether there might not exist binding sites for histamine other than mast cells and whether such binding sites also release their histamine in response to the 'histamine-liberators'. 


\section{CHAPTER XIV}

\section{NON-MAST CELL HISTAMINE: THE HIGH HISTAMINE CONTENT OF THE PYLORIC MUCOSA}

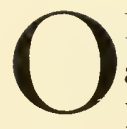

our return from the Histamine Symposium in London, Dr. West and I felt that it would be of interest to test some of the views which had been expressed on the possible origins of the histamine in mast cells. Instead we discovered a 'compartment' of tissue histamine which is neither contained within the mast cells, nor is it greatly susceptible to the action of the chemical histamine-liberators.

The experiment which disclosed this information was as follows. Three groups, each of twelve rats, were given a five-day course of compound 48/80 to reduce their mast-cell histamine to a low level. Thereafter, for six days, the first group received a daily intraperitoneal injection of $1 \mathrm{mg}$. histamine dihydrochloride, the second group received $1 \mathrm{mg}$. histidine daily, and the third group were given appropriate injections of saline. The histamine and histidine were themselves dissolved in saline; the volume of each injection was $1 \mathrm{ml}$. The diet consisted of 'Rat cubes' (North-Eastern Agricultural Co., Aberdeen) and abundant drinking water. Histamine was estimated in four animals from each group $(a)$ before starting the course of compound $48 / 80,(b)$ at day five, at the end of the course of compound $48 / 80$, and $(c)$ at day eleven during the recovery period when the various groups had received histamine, histidine or saline for six days following their initial depletion. Since it is generally believed that the main source of tissue histamine is the histidine in the diet, we anticipated that either, or both, groups receiving supplements would show a more rapid restoration of tissue histamine than the controls. For the same reason we included tongue, oesophagus, stomach (fundus and pylorus separately), duodenum, ileum, caecum and liver for histamine assay at each stage of the experiment. The results are expressed in Table XXI.

Examination of the findings shows, in the first place, that neither the intraperitoneal injection of histamine nor histidine has greatly affected the recovery rate of histamine in the tissues (a possible exception is the subcutaneous tissue of the group receiving supplementary histidine). Secondly, the pattern of depletion and recovery permits the various tissues to be grouped into three categories. In the first group are the tissues rich in mast cells which we have often examined in past experiments-ears, feet, subcutaneous connective tissue, mesentery and omentum, to which may now be added tongue, oesophagus and the fundus of the stomach: these all show a pronounced fall in histamine content, followed by a partial recovery by day eleven of the experiment. In 


\section{NON-MAST CELL HISTAMINE}

the second category are duodenum, ileum, caecum and liver in which the histamine values show little change throughout. However, there is a third category containing but one tissue, the pyloric half of the stomach, in which a slight fall in histamine content from an initial high value is followed, not merely by restoration of the initial level by day eleven, but by a considerable

\section{TABLE XXI}

Histamine values for a wide variety of tissues from rats, given compound 4880 and allowed to recover (a) on normal diet, (b) with added histamine, and (c) with added histidine. The only outstanding feature is the rapid over-compensation of the loss of histamine from the pyloric half of the stomach

\begin{tabular}{|c|c|c|c|c|c|c|c|c|c|c|c|c|c|}
\hline $\begin{array}{c}\text { Histamine } \\
\text { value } \\
\text { (ug. g.) }\end{array}$ & 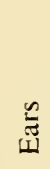 & ष्ّ & $\begin{array}{l}\stackrel{H}{u} \\
\dot{0} \\
\dot{B}\end{array}$ & 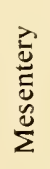 & 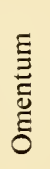 & 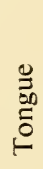 & 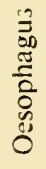 & $\underset{气}{\stackrel{气}{\Xi}}$ & $\frac{a}{2}$ & 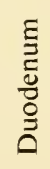 & 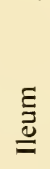 & E్ & : \\
\hline $\begin{array}{l}\text { Day 1, } \\
\text { starting value } \\
\text { Day } 5 \text {, full } \\
\text { depletion } \\
\text { Day 11, } \\
\text { partial } \\
\text { recovery }\end{array}$ & 10 & 10 & 12 & 11 & 10 & 14 & 15 & $\begin{array}{l}15 \\
10 \\
12\end{array}$ & 15 & $\begin{array}{l}18 \\
12 \\
12\end{array}$ & 14 & 16 & $\begin{array}{l}2 \\
2 \\
2\end{array}$ \\
\hline $\begin{array}{l}\text { Day } 11, \\
\text { Histamine } \\
\text { Day I1, } \\
\quad \text { Histidine }\end{array}$ & 15 & 12 & 10 & 5 & 14 & 16 & 5 & 12 & 50 & 16 & 14 & 14 & 2 \\
\hline
\end{tabular}

rise above its starting value. This conclusion is not altered by the findings in later work that the initial value for pylorus in this experiment was somewhat lower than normal.

We therefore examined the histamine and mast-cell contents of the pyloric portion of the stomach in more detail, scraping off the mucosa and estimating histamine separately in mucosa and 'muscle' (i.e. the rest of the stomach wall). The results of three such experiments are shown below in Table XXII.

\section{TABLE XXII}

Histamine values (ug./g. tissue) of the pyloric portion of rat stomach estimated (a) in intact tissue, and (b) after separation of the mucosa from the rest of the stomach wall ("muscle ')

\begin{tabular}{|c|c|c|}
\hline Tissue & (a) Whole thickness & (b) Separately \\
\cline { 1 - 2 } $\begin{array}{c}\text { Rat stomach } \\
\text { pylorus }\end{array}$ & $38,48,35$ & $\left\{\begin{array}{l}\text { Mucosa, 70,60, 60 } \\
\text { Muscle, 25, 12,18 }\end{array}\right.$ \\
\hline
\end{tabular}


Histological examination showed that the pyloric portion of the stomach of the rat is not especially rich in mast cells. A few are present in the submucosa, about the level at which the mucosa can be scraped off; but the mucosa itself is almost devoid of mast cells.

Further attempts to divide the wall of the rat's stomach into multiple slices parallel to the surface were not very successful. However, the pyloric portion of
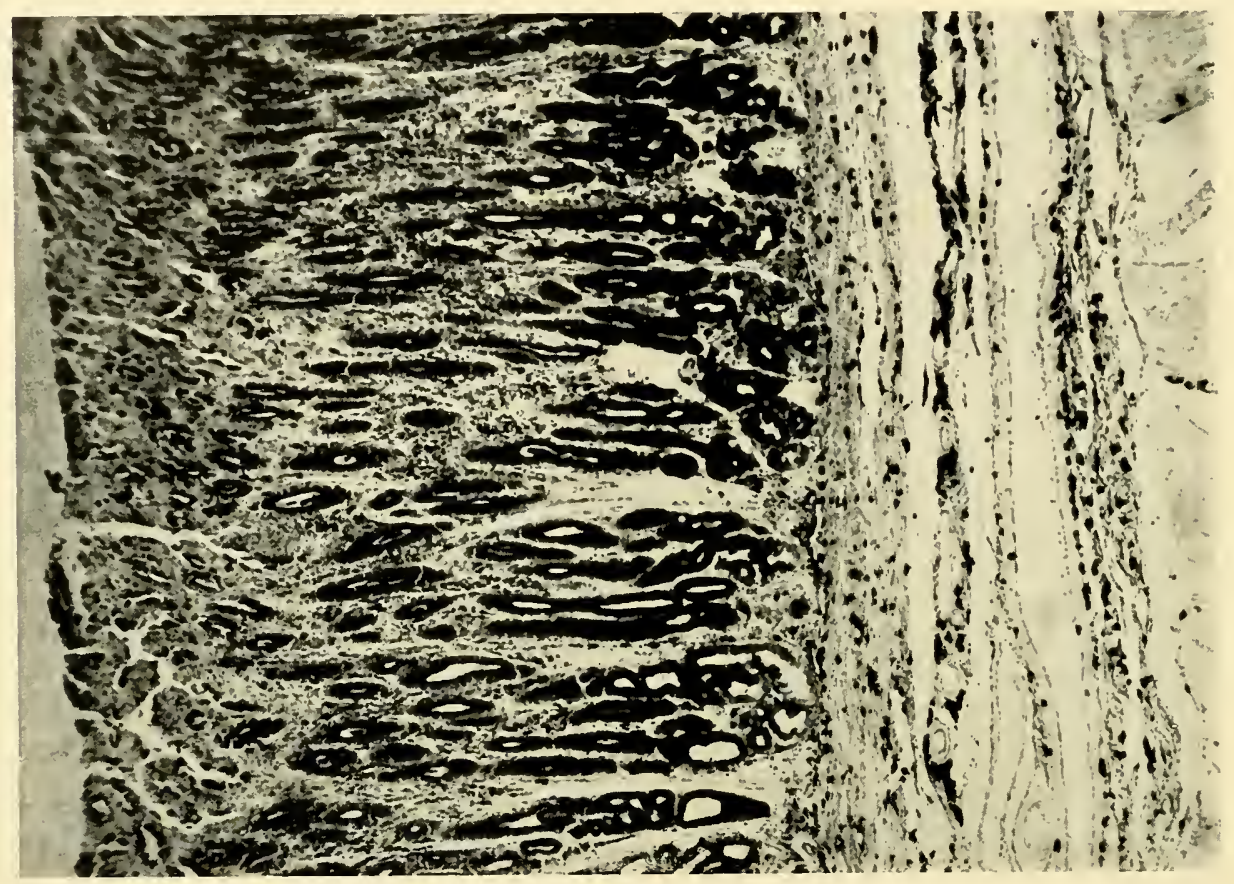

FIG. 51

Paraffin section through mucosa and submucosa of pyloric portion of hog stomach (the section is lying on its side to correspond with the next figure). The numerous dark spots in the submucosa are mast cells. A few mast cells occur in the deeper mucosa between the mucous glands, which also stain metachromatically with toluidine blue $(\times 44)$.

the stomach of the pig is not only thick; it also contains very many mast cells in the loose connective tissue on which the mucosa rests. We therefore prepared histamine- and mast-cell 'profiles' of the pyloric wall of hog stomach (Riley and West, 1956a).

Figure 51 shows, at low magnification, a vertical section through the mucosa and submucosa of the pyloric portion of hog stomach, fixed in the fluid recommended for mast cells by Constantinides (1953) and stained with $0 \cdot 1$ per cent aqueous toluidine blue. Even at this magnification the dense accumulation of mast cells in the submucosa is clearly visible. Under high power these cells are seen to contain granules which stain metachromatically (purple to red), 
the largest cells being related to the vessels which traverse the middle of the submucosa. A few similar, though smaller, mast cells accompany the loose connective tissue upwards between the tubular pyloric glands. In view of the obvious differences in mast-cell content of mucosa and submucosa, it was of interest to determine the relative values for histamine in these two layers.

Mast cells were counted in the paraffin sections, using a binocular Watson microscope of standard tube length, eye-piece $\times 8$, and objective $\times 50$, giving a final magnification of 600 diameters. Figure 53 records the average number of mast cells per twenty fields at each of eleven levels, from the surface of the

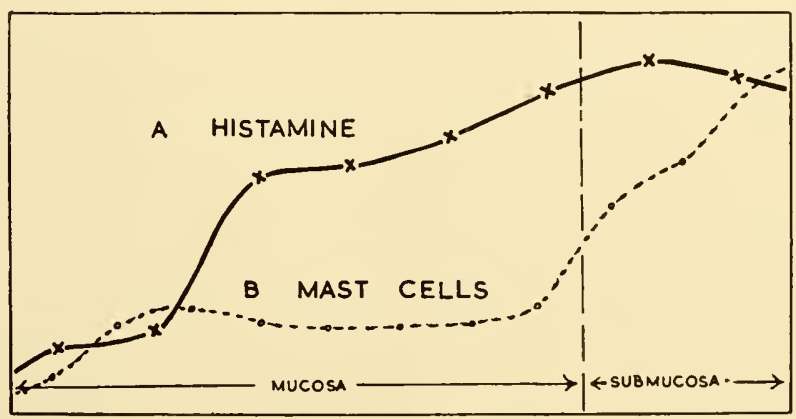

\begin{tabular}{|c|c|c|c|c|c|c|c|c|c|c|}
\hline 18 & 22 & & 67 & 67 & & & 90 & \multicolumn{2}{|c|}{100} & 93 \\
\hline 2 & 5 & 6 & 5 & 5 & 5 & 5 & 6 & 12 & 14 & 22 \\
\hline
\end{tabular}

FIG. 52

Histamine values (A) and mast-cell contents (B) at various depths in the mucosa and submucosa of hog pylorus. It is clear that the sharp inflection in each curve occurs at a different level. Something other than mast cells is binding histamine in the deeper mucosa.

mucosa to the base of the submucosa. The underlying muscle was not examined in detail since preliminary observations had shown it to contain very few mast cells and very little histamine.

Histamine was estimated in frozen sections at eight levels in depth of the combined mucosa and submucosa (Fig. 52). Fresh tissue, stripped of its muscle, was cut, parallel to the surface, on the freezing microtome after the manner of Feldberg and Harris (1953), each tissue slice being then rapidly weighed and placed in 10 per cent trichloracetic acid for the extraction of its histamine. The subsequent assays were carried out either on the standard guinea pig ileum preparation or on the blood pressure of the atropinized cat.

RESULTS. If we consider first the findings for the submucosa, we see that the high mast-cell content (average, eighteen cells per field) has its counterpart in a correspondingly high value for histamine (average, $97 \mu \mathrm{g} . / \mathrm{g}$.). This is in 
line with what we have found elsewhere. On the other hand, when conditions in the overlying mucosa are examined, it is evident that here the rapid fall off in the mast-cell content (average, five cells per field) is not accompanied by a proportionate reduction in tissue histamine (average, $76 \mu \mathrm{g} . / \mathrm{g}$.) until a region close to the surface of the mucosa is reached. There is, in fact, almost a fourfold difference between the histamine-mast cell ratios in the submucosa and in the deeper mucosa. As stated above, there is good reason for believing that the histamine in the submucosa is due to its high content of mast cells; hence it is clear that something other than mast cells must be binding the histamine in the mucosa.

The most obvious choice for this second component which binds histamine in hog pyloric mucosa is the mucin of the goblet cells lining the lower two-thirds of the pyloric glands. Indeed, there is direct evidence that gastric mucin can bind histamine (Neugebauer and Schmid, 1949). Like the mast granules this deeper mucin also stains metachromatically with toluidine blue, as does an occasional strand of mucus lying free in the lumen of the stomach, whereas the mucin of the surface cells and most of the secreted mucus stain orthochromatically (blue) with toluidine blue. It is unfortunate that we have as yet no method for fixing the histamine in situ to demonstrate its presence directly by histochemical techniques. The association of histamine with the metachromaticallystaining mucus is thus at present a matter of inference rather than proof. Nevertheless, it is of interest that here is a site, rich in histamine and yet comparatively poor in mast cells. At present we are at a loss to explain the functional significance of this high concentration of histamine and its regional distribution in the mucosa of the pyloric half of the stomach. 


\section{THE FUNCTION OF HEPARIN}

\section{Peptone shock in the dog}

HE feeling of uneasiness regarding the alleged function of heparin in
the body, mentioned in the introduction, became even more acute
as the present work progressed.

The histological investigations on the distribution of the mast cells in various species and on the relationship of the mast cells to the small blood vessels, studied in detail in the ox and rat, left little doubt that tissue mast cells secrete their metachromatic substance not directly into the blood, but into the tissue spaces and thence by the lymphatics to reach the blood, if at all, by a circuitous route. Heparin (or heparin combined with its albumin co-factor) is too big a molecule to re-enter the venous capillary circulation; applied direct to the capillary wall, heparin lodges in the interendothelial cement (MacIntosh, Ciba Symp. 1956, p. 407). It was clear, even at this point, that the earlier hypothesis could hardly be correct. There is no easy entry for heparin into the blood in most species. The function of heparin must lie in the tissues.

However, there still remain unexplained the phenomena of peptone and anaphylactic shock in the dog, in which it is certain that heparin and histamine do reach the general circulation, and that the massive release of both occurs mainly in the liver (Wilander, 1938; Rocha e Silva et al, 1947; Jaques et al, 1954).

In earlier (unpublished) work I was impressed by the consistent, though slight, differences in time sequence of the histamine and heparin peaks in the blood in peptone shock: this step-wise release, first of histamine which causes the 'shock' and, second, of heparin which causes the incoagulability, at first sight appears to weigh seriously against a common origin for the two substances. Yet logical extension of the knowledge which we have gained of tissue mast cells in general, to the special case of the shocked dog, suggests an interesting and plausible explanation why histamine and heparin must be 'out of phase' in their entry into the peripheral blood: for if heparin in the tissues is drained (if it is drained at all) by way of the lymphatics, then heparin from the liver will be drained in similar fashion; and the main efferent lymphatic pathway from the liver to the blood is the thoracic duct. Here the pathway is direct.

Thus we may picture the peptone acting on the mast cells in the liver of the dog: this explains the few seconds' delay between the moment of injection of the peptone and the onset of the shock. It is the characteristic delay of a histamine-liberator seeking its target, the mast cells. However, at this point the routes of the two components of the mast cells diverge: histamine enters 
the blood by the suprahepatic veins and soon causes spasm of their sphincters. The liver swells and its lymph drainage is enormously increased, flushing the heparin into the general circulation by way of the thoracic duct. Once the normal route for histamine is closed by spasm of the suprahepatic sphincters the remainder of the histamine will accompany the heparin in the lymph.

I suggested this hypothesis of peptone shock at the Histamine Symposium (p. 407). Later, Dr. West and I sought the experimental data to test its validity. We cannulated the thoracic duct in the thorax of three dogs (after resecting some of the lower left ribs to gain access to the posterior surface of the pleura) and took repeated samples of blood and lymph both before and after injecting peptone into the portal, or into a femoral, vein. Unfortunately, we had no facilities for keeping dogs beyond the stage of the acute experiment, and we felt that the results obtained with such preparations were open to objection from several points of view. It is also difficult to find and cannulate the thoracic duct without first giving the dog a fatty meal; but if this is done, the induction of peptone shock becomes more difficult since dogs do not give a well-marked response to peptone unless they have been starved for some hours beforehand. Nevertheless, we found that the first histamine does enter the blood directly very early in the shock and that the heparin lags behind and reaches the blood almost exclusively through the thoracic duct. Normal lymph clots, as does blood plasma. In peptone shock the thoracic duct lymph soon becomes incoagulable. It is of interest that White and Woodard (1957) have since shown that our unpublished data were sound.

\section{Fate of heparin in the rat treated with a histamine-liberator}

Further evidence against the view that heparin from the tissue mast cells is a natural anticoagulant was obtained by comparing conditions in the dog and rat. There are very few mast cells in the liver of the rat, though they are common in the peritoneum and are extremely numerous in the connective tissue. One might therefore expect this connective tissue to be the "shock organ ' of the rat and to release both histamine and heparin into the blood if the older views on heparin are correct.

The following experiment was carried out to test this point (Riley et al, 1955). Two groups of eight female Wistar rats, of 200-250 g., were used. The first received intraperitoneally over a period of five days progressively increasing doses of compound $48 / 80$ in saline, by which time $1 \mathrm{mg}$. per $100 \mathrm{~g}$. bodyweight could be given without eliciting signs of shock. The second group was given equivalent volumes of saline intraperitoneally as a control. Whole blood clotting times were measured repeatedly by the capillary tube method, and samples of urine, collected on filter paper, were tested for metachromatism with a weak solution of toluidine blue. At the end of five days the two groups 
were killed and skinned, and as much subcutaneous connective tissue as possible was scraped off. Representative tissue spreads were examined histologically for mast cells, the remaining subcutaneous tissue (about $60 \mathrm{~g}$.) in each group being then pooled and assayed for histamine and heparin as previously described (Cass et al, 1954) except that on this occasion we used the thiocyanate method (Snellman et al, 1948) for the initial extraction before finally purifying the heparin by the method of Charles and Scott (1933).

Compound 48/80 in the dosage used produced widespread degranulation and disruption of the mast cells in the dermis of rats, and almost complete loss of its tissue histamine-a drop from 26 to $1.5 \mu \mathrm{g}$. $\mathrm{g}$. tissue ( 94 per cent loss). On the other hand, the total heparin content fell only from $10 \cdot 0$ to $4.7 \mathrm{i} . \mathrm{u} . \mathrm{g}$. (53 per cent loss). Thus the almost complete release of histamine from the subcutaneous connective tissue of the rat by compound 48/80 was accompanied by a loss of only half the associated heparin, and even then there was no sign of the release of heparin into the circulating blood; the clotting time remained normal and no metachromatic material appeared in the urine. That the heparin extracted from the control series did in fact possess anticoagulant activity was confirmed by its action on normal rat blood in vivo and in vitro. Another histamine-liberator, diaminodecane, has been found to act in similar fashion (Braunsteiner et al, 1957).

So far as present evidence goes, both the rabbit and the guinea pig resemble the rat in their failure to show changes in blood coagulability during anaphylactic shock (Adams, 1953). The time has surely come for us to acknowledge the slenderness of the argument which links the dramatic events of peptone and anaphylactic shock in one particular species, the dog, to the function of heparin, and hence, of the mast cells in general.

\section{Mast cells and the connective tissues}

The problem thus remains: what becomes of the 'heparin' which is released from the tissue mast cells in species other than the dog? We have noted earlier that some of the metachromatic material from disrupted mast cells may be disposed of locally by macrophages and fibroblasts, some may adhere to adjacent connective tissue fibrils or cells, while some may be bound by the basic histamine-liberator itself. Pure heparin can be shown to interact with soluble collagen protein in vitro, but the resulting fibrils do not closely resemble the fibrils of natural collagen (Morrione, 1952). However, Higginbotham and Dougherty (1956) have recently confirmed, by an elegant technique, that metachromatic granules released into the tissues from mast cells are quickly phagocytosed and digested by nearby fibroblasts (Maximow, 1904; Brodersen, 1928). These workers have thus supplied an important piece of evidence for the hypothetical scheme of the 'dynamics of the connective tissues' which I 
put forward in the Ehrlich Centenary Lecture on the Mast Cells (Riley, 1954) by directly relating the release of metachromatic material from the mast cells to the fresh formation of ground substance by the connective tissue cells.
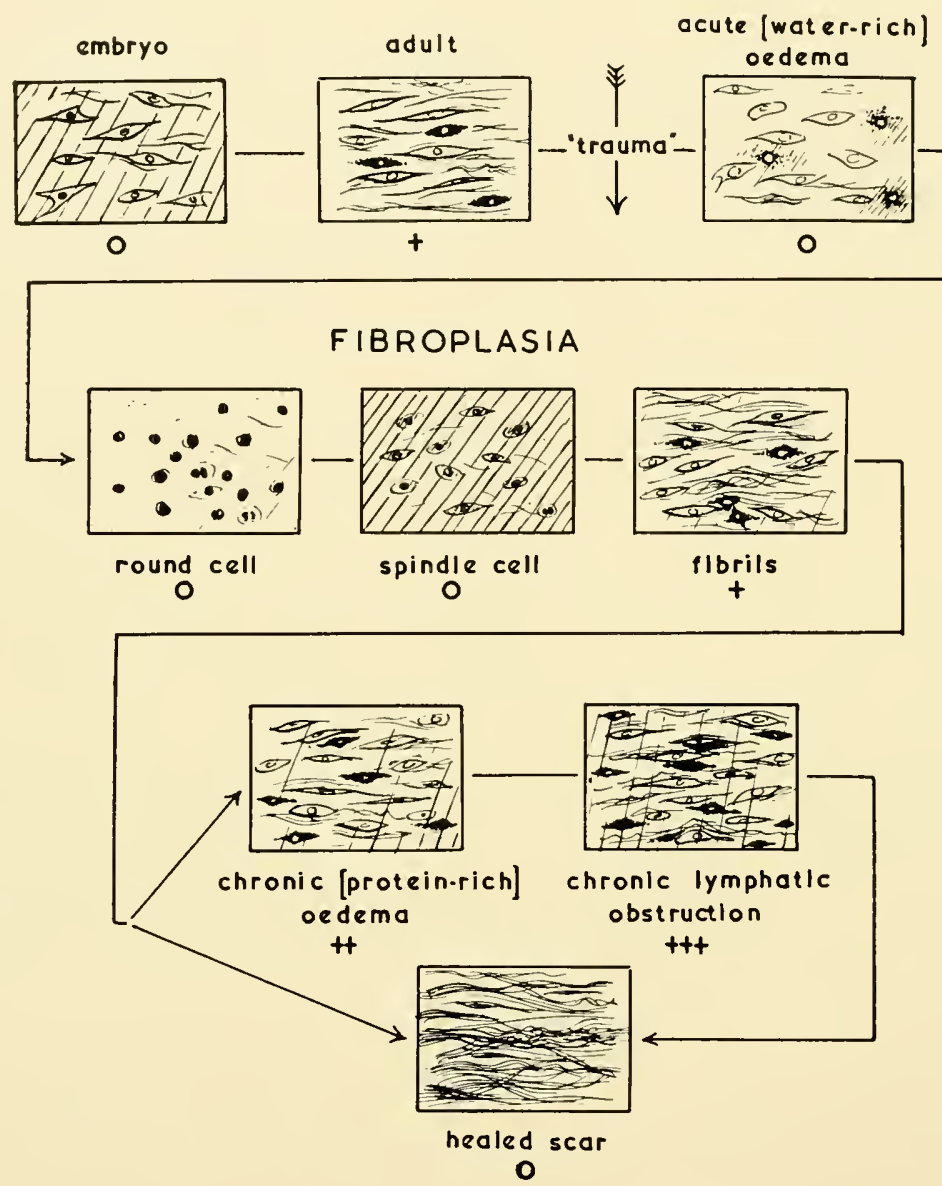

FiG. 53

Diagram to show the participation of the mast cells in the dynamics of the connective tissues. Mast-cell content is indicated by the signs $\mathrm{O}$ to +++ ; the cross-hatching indicates metachromatic ground substance. (See Riley (1954). Lancet, p. 841.)

The proposed scheme for the participation of the mast cell in the dynamics of the connective tissues, mentioned above, is illustrated in the sequence of events shown diagrammatically in Figures 53 and 54. Mast cells are not present in the early embryo; they appear in their characteristic locations only towards the end of embryonic life when they rapidly fill with granules (Laguesse, 1919; Hjelmman, 1954; Kitanishi, 1956). This is the sequence epitomized in the 
umbilical cord and described earlier (p. 15). If, however, the connective tissue is later subjected to trauma-mechanical, chemical, thermal, bacterialwhereby an 'acute watery oedema' is produced (Drennan, 1951), the mast cells promptly release their metachromatic substance into the tissues (Sylvén, 1941; and see Figs. 47 and 48). The appearance of tissues thus mobilized for regeneration and repair closely resembles the histological conditions of embryonic connective tissue (Holmgren, 1939, 1940). Fibroplasia of shorter or longer duration follows, and, as recognizable collagen begins to take its shape,

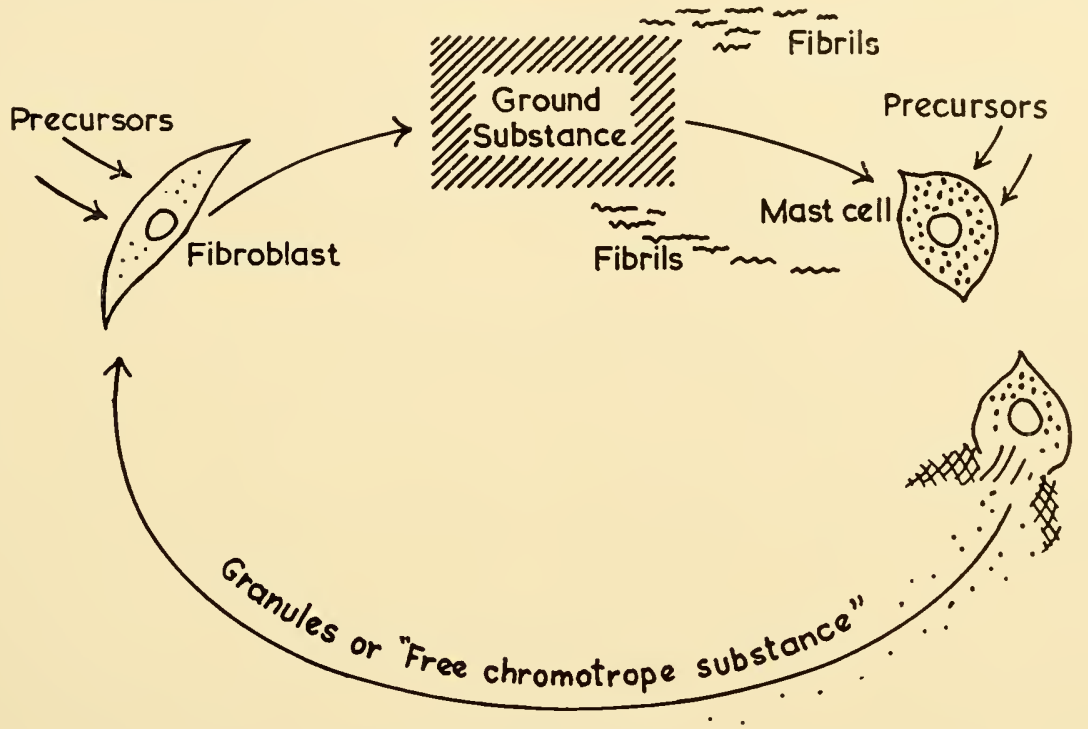

F1G. 54

The Mast-Cell Cycle. This illustrates the part played by the mast cell in the local events of the connective tissues. Ground substance, derived originally from the fibroblast, is ultimately stored in altered, compact form in the mast cell: following 'trauma' it can again be released and re-enter the cycle via mesenchymal cells whose main source of fuel is the blood stream.

mast cells once more appear in the reactive zone (Staemmler, 1921). Should fibroplasia be unduly protracted, as in chronic inflammation, the mast-cell population further increases (Janes and MacDonald, 1948); and in conditions of chronic lymphatic obstruction, in which the tissue spaces remain loaded with protein-rich oedema fluid, both connective tissue hyperplasia and mastcell hyperplasia become extreme (Bäumer, 1896). The end-point is reached with the formation of avascular scar tissue in which neither fibroblasts nor mast cells are now present (Neumann, 1890).

Such is the observed sequence; the difficulty lies in the interpretation. The cyclic changes in the mast-cell population of loose connective tissue certainly suggest that the mast cells are concerned in some way with the function of that 
tissue, and the clue may lie in the distribution of the metachromatic material. The two types of metachromatism - the diffuse metachromatism of ground substance and the compact granular metachromatism of mast cells-are present alternately in the series of changes outlined above, suggesting that whatever their chemical relationship may be they bear an inverse functional relation to one another. The precursor of the metachromatic ground substance present in the embryo would seem to stem from the connective-tissue cells themselves and may undergo further elaboration in the tissue spaces (Schoenberg and Moore, 1958). The major component of the ground substance is generally

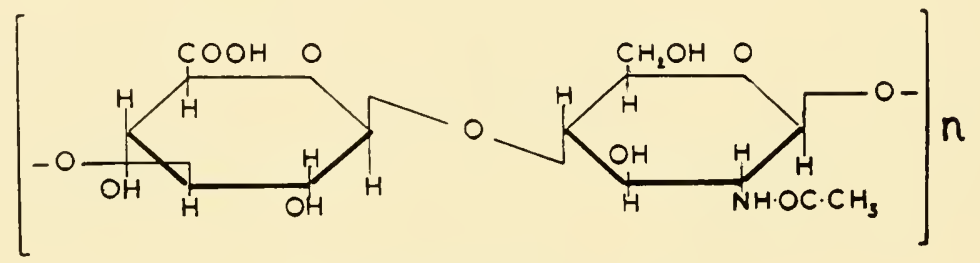

HYALURONIC ACID

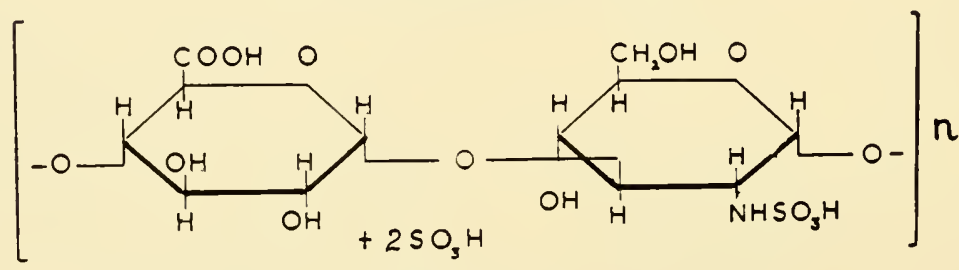

HEPARIN

FIG. 55

Suggested formulae for heparin and hyaluronic acid. (Redrawn from Burkl, 1952.) (See Riley (1954), Lancet, p. 841, fig. 1.)

believed to be hyaluronic acid. As cellular differentiation advances and the ground substance shrinks, metachromatic mucopolysaccharides are seen to concentrate as granules in the tissue mast cells. Yet this is more than a simple phagocytosis of mucopolysaccharides by the mast cells. In addition to the esterification of the molecule by sulphate, its internal structure is radically changed. Indeed, complete hydrolytic breakdown of hyaluronic acid must first occur before a re-synthesis to heparin is possible (Fig. 55). Yet in this way the building blocks of a strongly hydrophilic colloid (hyaluronic acid) can be stored in compact, dehydrated form (heparin), as foodstuffs were concentrated and stored during the past war. Speculating thus, a hundred years after the birth of Ehrlich, we come back to his original view of the mast cell as a "wellfed cell' of the connective tissue.

Within recent years a number of workers have come to favour some form of this general hypothesis relating the mast cell to the connective tissue. Sylvén 
(1941, 1957), following the lead of Staemmler (1921), believes that the mast cell produces the metachromatic ground substance ("free chromotrope substance") of granulation tissue. Asboe-Hansen $(1951,1954)$ states even more emphatically that the mast cell, under hormonal control, secretes the hyaluronic acid of the ground substance, perhaps by way of a heparin-like precursor. But the facts (1) that in normal development in the embryo and in chronic inflammation in the adult, the metachromatic ground substance is laid down before the mast cells appear, and (2) that fibroblasts and synovial cells in vitro are capable of forming hyaluronic acid in the medium without the participation of mast cells, both tend to shift the initiation of the production of ground substance to the connective tissue cells themselves (Campani, 1951; Grossfield et al, 1955; Taylor and Saunders, 1956; Castor, 1957). According to Meyer (1950, p. 32): 'fibroblasts secrete large amounts of acid mucopolysaccharides together with a globular native protein, the precollagen. ... The regularly spaced acidic groups of the polysaccharide chain would form a template, so to speak, on which the fibrous proteins are built. The mucopolysaccharides which first form a sheath on the fibrils would then be removed by enzymatic digestion.' It is at this stage that the mast cells appear: the mastocytosis is a secondary event (Riley, 1954).

Endothelial cells, mesothelial cells, synovial cells and fibroblasts have much in common (Grossfeld et al, 1955). Synovial joints develop as clefts in the embryonic mesenchyme; adventitious bursae readily form in the connective tissue of the adult. Even the vascular endothelial cell is now believed to furnish its own coat of sulphated mucopolysaccharide (Curran, 1957). A surface secretion of a cell in one situation is an intercellular secretion in another. And in every case it is possible to envisage a final concentration and storage of altered mucopolysaccharide in the granules of tissue mast cells. Under suitable circumstances the granular mucopolysaccharide can again be released and find its way back into the fibroblast (Fig. 54). At the same time, it is clear that the metachromatic substance of the mast cell is but one source of fuel for the connective tissue cell and that the mast cell, in turn, can flourish in the absence of fibroplasia, as in the mast-cell tumours. Nevertheless, there are grounds for the belief that a local mast-cell cycle may operate in the tissues and that this, in turn, is geared to the major cycle of lymph and blood. In any event, the emergent route for heparin from the mast cell must surely be by way of the lymphatics.

More facts are needed for a final evaluation of the role of the mast cell in the connective tissues. For the moment we must leave it that a local 'mastcell cycle' may play its part in the deposition, absorption and redeposition of fibrils in connective tissue and that there is growing evidence that this is so. 


\title{
CHAPTER XVI
}

\section{MAST CELLS AND HISTAMINE IN THE SKIN}

\author{
(See Riley and West, A.M.A.Arch. dermatol., 1956b)
}

\section{MAST CELL-HISTAMINE`PROFILES`IN NORMAL SKIN}

\begin{abstract}
7 HE classical studies of Lewis (1927) and Dale (1929a and b) clearly established the role of histamine in the reactions of the skin to injury.

It was thus of interest to examine the skin of various species and to determine the extent to which the distribution of the histamine in each is related to the distribution of its mast cells.

This study shows that at least so far as the skin of man, mouse, rat, cat, dog. ox, pig, guinea pig, and rabbit is concerned, the bulk of the extractable histamine is situated in that part of the skin which contains most mast cells.
\end{abstract}

\section{Histamine and mast cells in ears}

In the course of a survey of the development of mast cells in the skin of the embryo, it was noted that the cells often appear first and are later extraordinarily numerous in the ear. This finding was of particular interest in view of contemporary work by Feldberg and Miles (1953), who showed that the ear of the guinea pig is comparatively rich in histamine. Histological studies confirmed that mast cells, though sparse in the skin of the guinea pig, are most numerous in those regions in which Feldberg and Miles had obtained their highest values for histamine-nipples, perivaginal skin, and the skin of the ear. It was therefore decided to examine the ears of some of the larger domestic animals in which a simple dissection of the tissues might suffice to indicate which part of the ear contains the maximal concentrations of mast cells and of histamine.

MATERIALS AND METHODS. Whole ears of cattle and pigs obtained fresh at the slaughter-house were split vertically down the midline, and representative whole-thickness blocks for histology were removed from the base, centre and tip. Next, the upper and lower skin coverings were freed from the intervening cartilage by sharp dissection, and further samples of the various parts were removed for histological examination. All tissue blocks were placed at once in the fixative recommended for mast cells by Constantinides (1953) and were later embedded in paraffin, cut at $8 \mu$ and stained for mast cells with a $0 \cdot 1$ per cent aqueous solution of toluidine blue. Other sections were stained by the haematoxylin-eosin method for general histological detail. Mast cells were then 


\section{MAST CELLS AND HISTAMINE IN SKIN}

counted in the toluidine blue preparation at a magnification of 120 diameters using a binocular Watson microscope of standard tube length, eye-piece $\times 8$ and objective $\times 16$. Ten fields, chosen at random, were counted for each tissue layer, the results being expressed as 'mast cells per microscope field'. For the pharmacological assays, weighed portions of tissue adjacent to those selected

TABLE XXIII

Regional variations in histamine and mast-cell

contents in hog ear

Upper Surface

\begin{tabular}{|c|c|c|c|}
\hline \multirow{3}{*}{ Basc } & $25(81)$ & & $31(129)$ \\
\hline & Central & $2(0)$ & Cartilage \\
\hline & $10(44)$ & & $18(58)$ \\
\hline
\end{tabular}

\section{Lower Surface}

Histamine values are expressed as micrograms per gram; corresponding mast-cell contents (in parentheses) are average figures for 10 standard microscope fields, counted from vertical paraffin sections. There is a positive correlation between histamine and mast cells in each region, and a gradient in both which increases towards the tip of the ear.

TABLE XXIV

Histamine contents and mast-cell values for ox ear

Upper Surface

\begin{tabular}{|c|c|c|c|c|}
\hline & $15(26)$ & & \multirow{2}{*}{$24(45)$} & \\
\hline \multirow{3}{*}{ Base } & $28(50)$ & & & \multirow{3}{*}{$32(63)$} \\
\hline & Central & $5 \cdot 5(0)$ & Cartilage & \\
\hline & $15(28)$ & & $22(37)$ & \\
\hline
\end{tabular}

Tip

Lower Surface

As in hog ear, the values both for histamine and for mast cells (in parentheses) are higher in the upper than in the lower skin and increase towards the tip of the ear where maximal concentrations are found. The few mast cells in the perichondrium have not been recorded.

for histological examination were immersed as soon as possible in 10 per cent solution of trichloracetic acid and were later extracted and assayed for histamine, as in previous work (Riley and West, 1953), using either the guinea pig ileum preparation or the blood pressure of the atropinized cat. Histamine values are expressed as micrograms of histamine base per gram of fresh tissue.

Results. Tables XXIII and XXIV illustrate the findings for histamine and mast cells in the ear of hog and ox. In both species there is a close 
parallelism between the histamine values and mast-cell contents of the various topographical regions of the ear. Thus, there is more histamine in the upper than in the lower skin, and more at the tip than at the base. The central cartilage, though displaying as strong a metachromatism as the mast granules, contains little histamine, and even this may perhaps be due to the few mast cells in the perichondrium. A high content of mast cells has been previously noted

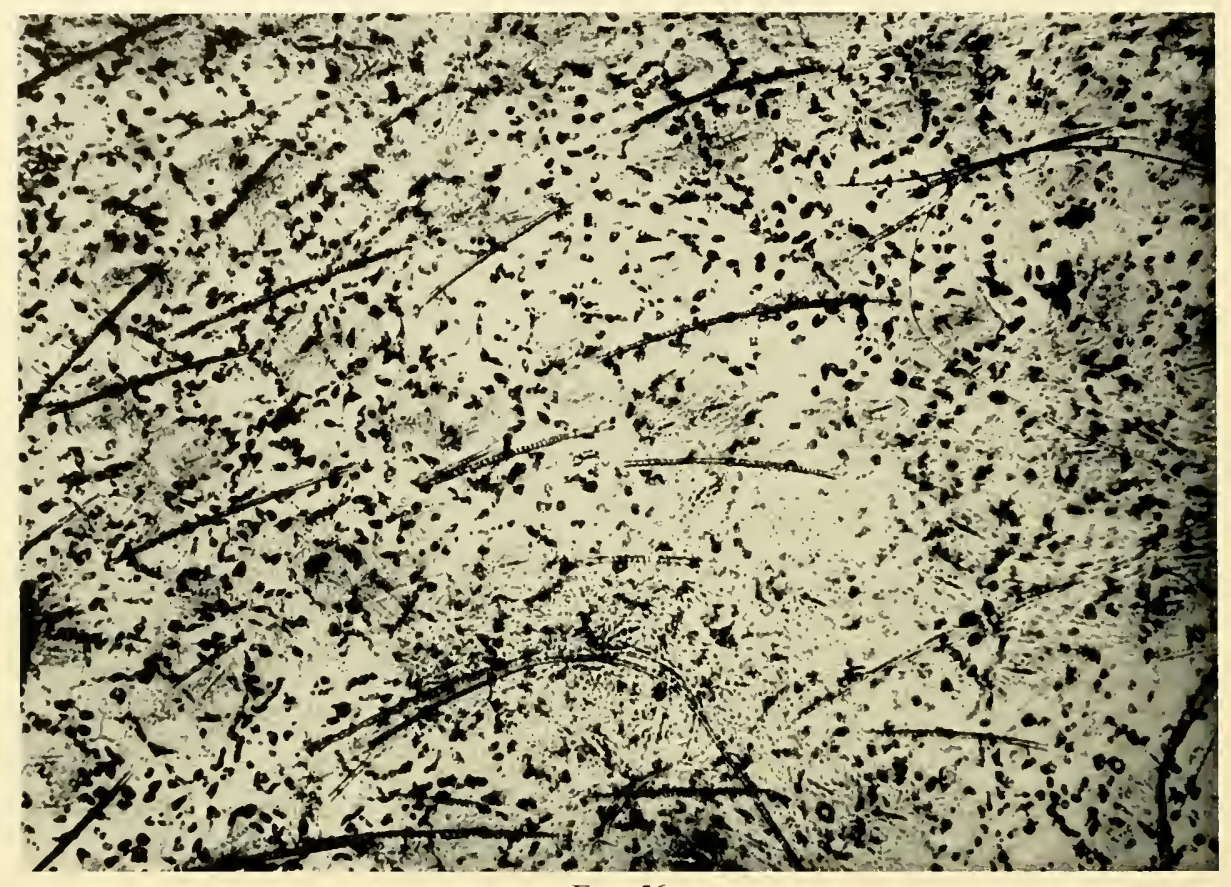

F1G. 56

Whole mount, upper skin mouse ear. Fixed alcohol, stained toluidine blue $(\times 64)$. Enormous numbers of mast cells are present; many of them surround the hair follicles. The skin of the ear contains proportionately more histamine than any other tissue.

in the ears of mice and rats (Figs. 18 and 56). However, the ears of these smaller animals are less suited to a regional survey of mast cells and histamine than are the ears of larger animals. Only the upper skin of the ear of the mouse and rat can readily be stripped off the cartilage, though it has the advantage of being so thin that it can be examined histologically as a whole-mount preparation (Fig. 56). This upper skin in mouse and rat contains about three times as much histamine as the remainder of the ear, cartilage and lower skin together.

Thus, these preliminary findings using the ears of various species support the idea that there is a close association between the histamine content of a 
given tissue and the density of its mast-cell population. This becomes more apparent when the skin elsewhere is examined.

\section{Histamine and mast cells in abdominal skin}

As Table XXIV indicates, it was found possible to subdivide whole skin from the base of the upper surface of ox ear into two parts, an inner and an outer layer. Here it was observed that both mast cells and histamine are

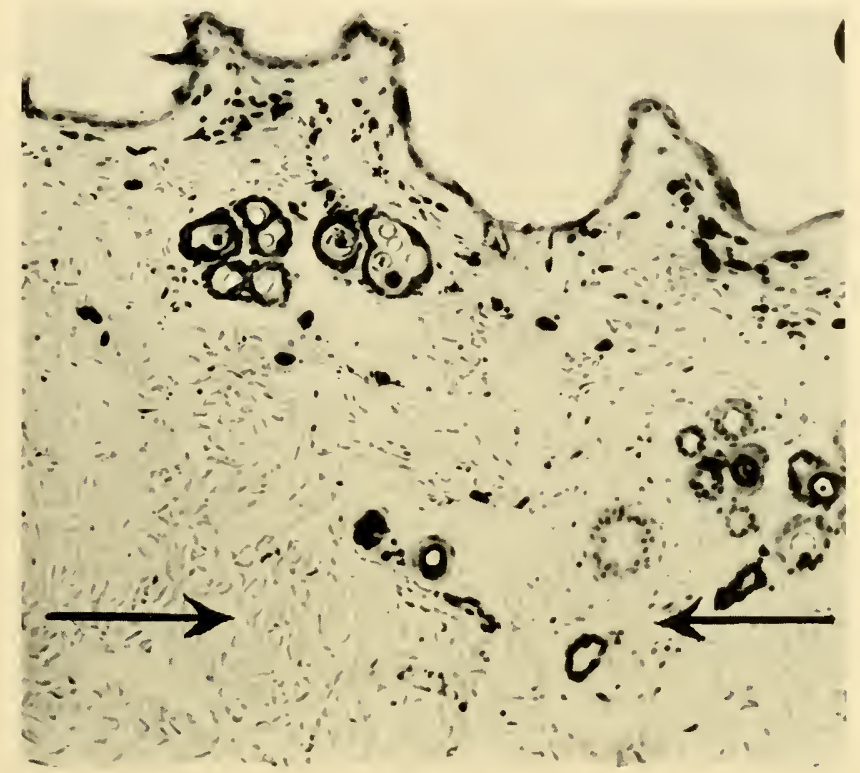

FIG. 57

Vertical section cat skin. Toluidine blue $(\times 144)$. The majority of the mast cells are small and lie close under the epidermis. Both they and the histamine remain behind when the dermis is scraped off at the level of the arrows.

concentrated mainly in the inner, or dermal, layer. This suggested that it might be feasible to examine the skin of other species in this way, scraping off as much as possible of the dermis and examining it and the remaining upper layer separately for mast cells and histamine. Since the method is essentially comparative, each portion serves as a control for the other.

MATERIALS AND METHODS. Samples of fresh abdominal skin from guinea pig, rabbit, dog, cat, mouse, and rat were pinned out on a board, fur side down, and as much as possible of the dermis was scraped off with a scalpel. Human skin, obtained fresh at operation from mastectomy specimens, was subdivided in the same way. Tissue spreads were made from the inner, or dermal, layer, and paraffin sections from the remaining outer layer, which consists of epidermis 
and its appendages together with a layer of dermis whose thickness varies from one species to another. These preparations were then compared with paraffin sections of whole-thickness skin to determine the level at which the separation had been made. Mast cells were counted as before in the inner and outer zones

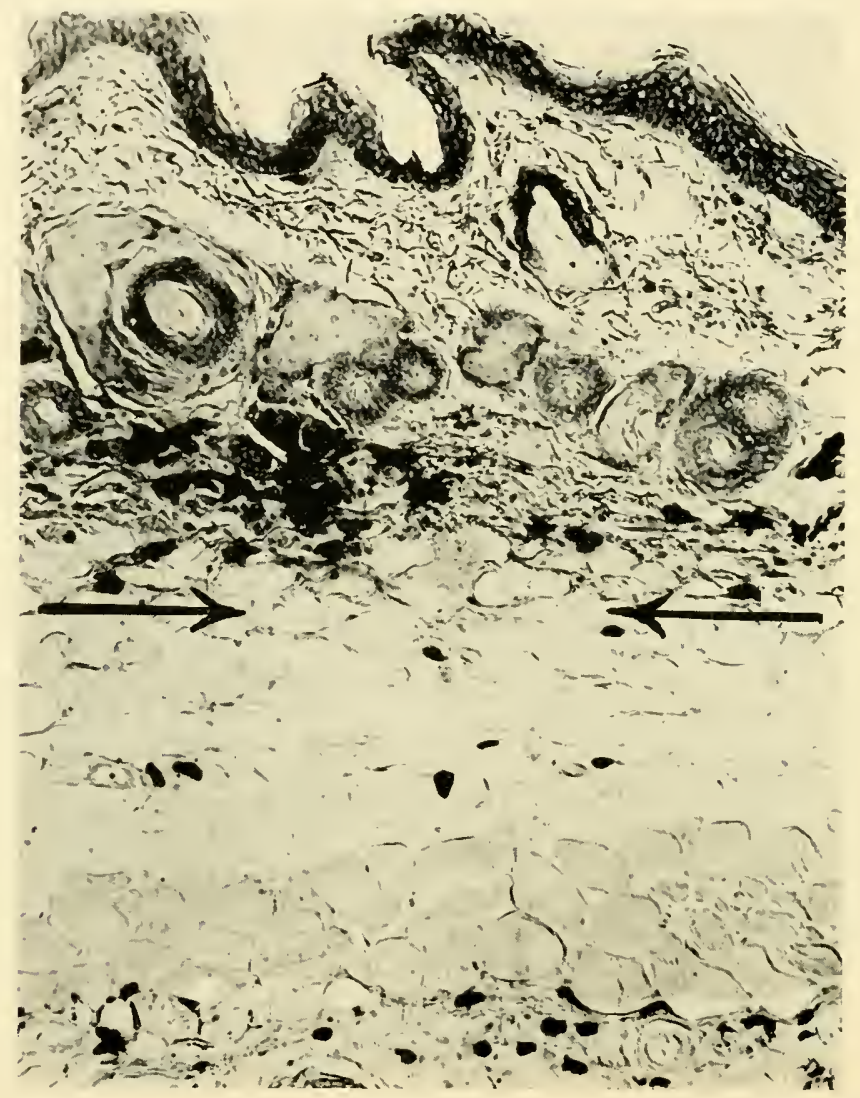

FIG. 58

Mouse skin. Staining and magnification as in Fig. 57. The mast cells in the skin of the mouse are disposed in two layers, inner and outer, and are mainly big cells (see also Fig. 61). Splitting the skin at the level of the arrows results in an almost equal division both of mast cells and histamine.

of the sections of intact skin, corresponding values for histamine being obtained from samples of the separated inner and outer layers. The results are set out in Table XXV.

RESULTS. Again there is a striking parallelism between the mast-cell content and the histamine value in the various layers of skin in every species examined. This is particularly evident in those animals in which the skin histamine is 
high-cat, mouse, and rat. The histological appearances in these three species are shown in Figures 57, 58 and 59 which are all of the same magnification; the arrows indicate the level at which the dermis can be scraped off. When the histological appearances are compared with the values for histamine in Table $\mathrm{XXV}$ we see that the mouse, with the highest total skin histamine, has two layers of mast cells and two concentrations of histamine-one in the inner and a second in the outer zone of skin. The cat and rat each have only one main

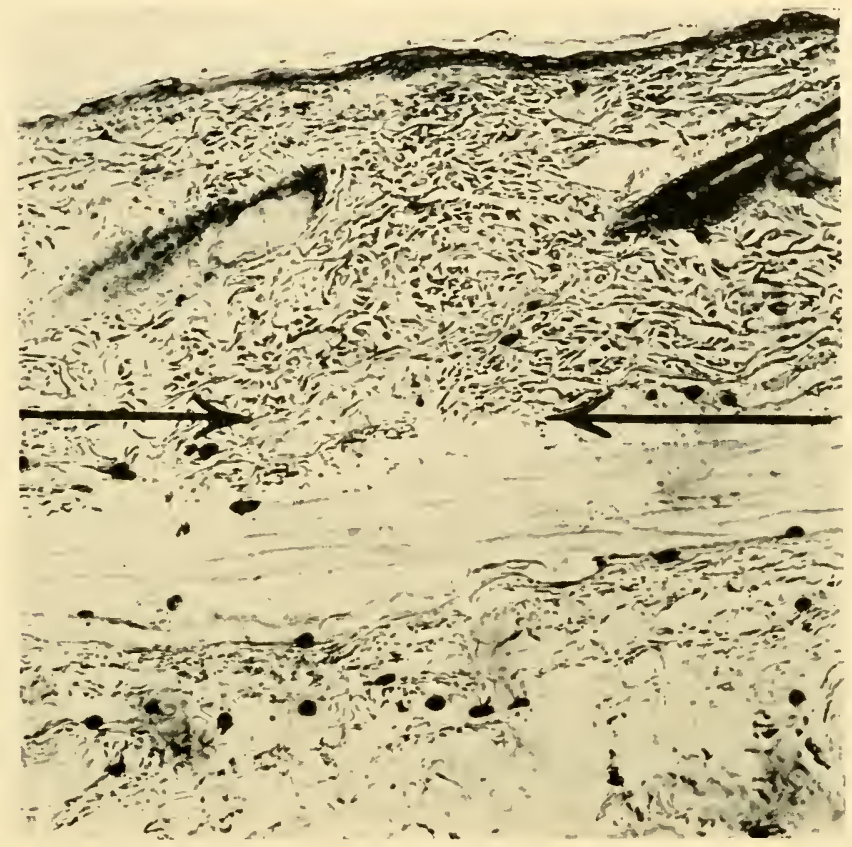

FiG. 59

Rat skin. Staining and magnification as in Figs. 57 and 58. Here the mast cells lie mainly below the arrows and are removed, along with most of the histamine, when the dermis is scraped off. Contrast cat skin, Fig. 57.

concentration of mast cells and histamine; yet the two species differ in that the mast cells and histamine in the cat's skin are chiefly in the outer layer, close to the epidermis, whereas the mast cells and histamine in the rat are mainly in the inner layer, which can be removed by the technique described above. Not only do the various histamine values for the two layers reflect the number of mast cells in each; they also reflect to some extent the size of the cells comprising the layer. Thus it will be seen from Figures 57, 58 and 59 that the subepidermal mast cells in cat skin, though numerous, are small compared with the mast cells in the mouse and rat, and that the mast cells in the superficial layer in the 
skin of the rat are themselves smaller than the more deeply situated cells. It is curious that the smallest animal, the mouse, has the biggest mast cells and a double layer of them in its skin. Simple enumeration of the mast cells fails to record these qualitative differences.

\section{TABLE XXV}

Comparison of mast-cell contents and histamine valwes in the outer and inner zones of various species

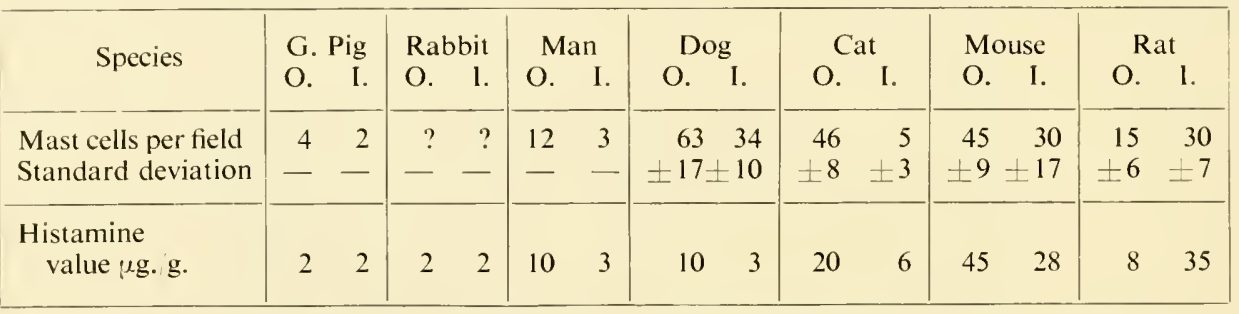

$\mathrm{O}=$ outer zone: $\mathrm{I}$ inner zone. When the mast-cell count is high, the standard deviation is also given. The cells in the guinea pig are very small, and in the rabbit are so few that no accurate figure can be supplied. In the remaining species there is a close correlation between the number and size of the mast cells and the local concentration of tissue histamine.

\section{Histamine and mast-cell profiles in the skin of the cat}

The success which attended the above procedure of splitting skin into an inner and an outer layer suggested that it might be worthwhile to attempt a more thorough division of skin from various species into several layers, using the 'histamine profile' method of Feldberg and Harris (1953) and combining it with a histological assessment of the mast cells at the various levels. Comparatively thick skin is required for this purpose. Data for dog skin have recently been submitted by Graham and associates (1955), hence, by way of illustration, only the results with cat skin are recorded here.

MATERIALS AND METHODS. Freshly excised abdominal skin of the cat was clipped short, and portions of suitable size were placed on the freezing microtome and sliced, parallel to the surface, at an average thickness of $40 \mu$. Alternate slices were either weighed separately and extracted for histamine, or were stained as frozen sections with toluidine blue and examined for mast cells. A further sample of the original specimen was fixed and embedded for paraffin sections. These were cut vertical to the surface in the conventional manner and were stained by the methods previously described.

RESULTS. There was no doubt as to the relative location of the mast cells in the frozen sections, though many of the cells displayed the dissolution of granules and diffusion of metachromatic material which follow the use of a watery technique (Michels, 1938). By far the greater number of mast cells were encountered in the first three slices below the epidermis, in which situation small granular mast cells of normal appearance were seen in the paraffin 
sections cut perpendicular to the surface of the skin. Two factors prevented accurate counts being made of the mast cells in the frozen sections; first, the actual thickness of the slices themselves $(40 \mu)$, and secondly, the loss of metachromatic material, referred to above, which made it difficult to identify the smaller mast cells. Accordingly, the requisite counts were made from the paraffin sections (of which Fig. 57 is an example) by projecting a series of

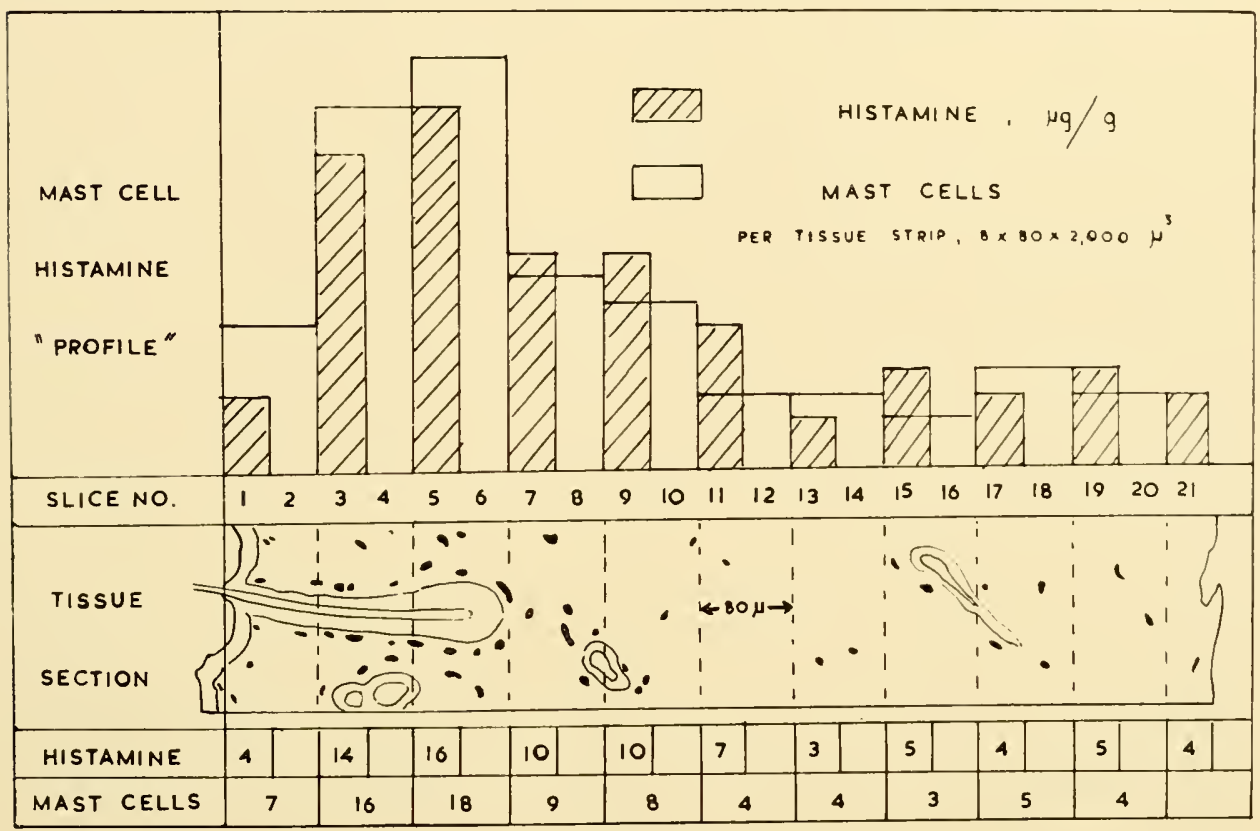

FiG. 60

Combined mast-cell and histamine 'profile' of cat skin. Part of a drawing of a section, made with the aid of a projection microscope, has been rotated to lie transversely across the diagram: the broken lines indicate the levels at which alternate frozen sections were cut and assayed for histamine. The histamine values are represented, along with the appropriate mast-cell counts, in the upper half of the diagram. The two 'profiles' show a striking resemblance to one another.

microscope fields on to paper previously subdivided at that magnification into strips $80 \mu$ wide by means of a stage micrometer. Once the first line had been adjusted to lie along the edge of the epidermis, the remaining pairs of lines enclosed zones of tissue corresponding to those from which the histamine samples had been taken in the frozen material. For convenience, mast cells were counted in strips $2000 \mu$ in length, i.e. in a block of tissue which, after fixation and sectioning at $8 \mu$, occupies a volume of $8 \times 80 \times 2000 \mathrm{cu}$. $\mu$. Calculation then shows that in the region of maximal concentrations of mast cells and histamine in the skin of the cat, each small mast cell contains approximately $1 \cdot 14 \mu \mu \mathrm{g}$. histamine. When the mast-cell counts and histamine values are plotted 
together (Fig. 60) an excellent correlation between mast cells and histamine is seen to exist throughout the entire thickness of the skin.

\section{DISCUSSION}

It is clear from the data which have been presented that in every species examined the quantity and distribution of the histamine in skin is paralleled by the relative density and distribution of the tissue mast cells. Taken in conjunction with previous work on mast cells and histamine in normal tissues, and especially in view of the very high histamine contents of mast-cell tumours from dogs, it would seem highly probable that histamine in general is concentrated in the mast cells. This conclusion is supported by a recent account by Graham and associates (1955) on the relationship of histamine to mast cells in the skin of the normal dog.

In the present work we see, first, that the curiously high mast-cell content in the skin of the ear has its counterpart in a high histamine content of similar regional distribution. Secondly, when samples of abdominal skin from various species are split into an inner and an outer layer, both the histamine and the mast cells become subdivided and partitioned in the same way. This is well seen in those three species in which the skin histamine is high-cat, mouse, and rat. The cat and rat differ in that the histamine and mast cells lie mainly in the outer and inner layers of the skin respectively. The mouse shows a combination of both patterns in having a double layer of mast cells, outer and inner, and a correspondingly high histamine value in each. Thirdly, when the skin of the cat is split into multiple layers and their mast cells are counted, a 'histamine profile' can be constructed which corresponds closely with the mastcell values at the various levels.

In comparison with the findings in cat, mouse, and rat, the mast-cell and histamine contents of human skin are not unduly high, though high values have been recorded earlier in this work for certain pathological tissues rich in mast cells, as in urticaria pigmentosa. Thus it would appear that the cytological location of tissue histamine is the mast cell, and that the gross values for histamine which have for long been recorded are, in the main, a reflection of the extent to which the tissue or organ contains mast cells. The present results indicate that this concept of the location of histamine in mast cells is applicable to the skin, the organ on which much of the classical work on histamine is based.

\section{THE MAST-CELL REACTION IN PRECANCEROUS SKIN OF MICE}

As stated in the introduction to this book, my interest in the mast cell was first aroused many years ago by a chance remark of one of my teachers who 
showed me a paraffin section of precancerous mouse skin which he had stained with eosin-toluidine blue. This simple alternative method of staining had immediately revealed a dense collection of dermal mast cells, not one of which could be recognized in a corresponding section stained by the routine haematoxylin-eosin method. However, it was only when I heard that nothing was then known of the mast cell's function that my curiosity was sufficiently stimulated to make me pause and read any subsequent reference to mast cells in the medical literature.

In 1938 I noticed an abstract of the paper by Holmgren and Wilander (1937) on the combined histological and biochemical work of Jorpes and his colleagues in Stockholm which appeared to show, beyond all reasonable doubt, that the mast cell is the site of formation, or storage, of the anticoagulant, heparin. Recalling my introduction to the mast cell, I obtained a sample of heparin ('Vitrum') from Stockholm in order to test its effect on mouse skin undergoing carcinogenesis by 1, 2, 5, 6-dibenzanthracene. Heparin was repeatedly injected under the precancerous skin in small doses in one group, and was painted on excised wounds in the epilated areas of skin in a second group. However, the results were disappointing. There was neither a definite promotion nor a definite retardation of tumour formation in either group when comparison was made with suitable controls.

In 1944 Cramer and Simpson published their careful study of the mast-cell reaction in precancerous mouse skin and reviewed the literature. These workers brought forward one additional piece of evidence which at least seemed to show that many of the mast cells in precancerous mouse skin do differ qualitatively from normal mast cells. They noticed that the more superficial mast cells tend to lose their metachromatism rather easily in a watery fixative and that many of them, in frozen sections, exhibit a golden-brown fluorescence in ultra-violet light.

During the present study I have returned repeatedly to this puzzling phenomenon and have re-cut, stained and reviewed many of my old sections of mouse skin in various stages of carcinogenesis and have examined the topical effect of still other hydrocarbons dissolved in a non-irritant solvent, acetone. The results are consistent. A polycyclic hydrocarbon capable of inducing epilation, epithelial hyperplasia and the development of a mast-cell reaction in the underlying dermis is carcinogenic. As Orr (1938) has pointed out, the dermal changes spread gradually deeper and include the breaking up of the refractile collagen bundles, changes in the elastica, fibroplasia and the accumulation of tissue mast cells (Figs. 61-63). Orr, however, states that the mast-cell reaction is not specific for carcinogenesis and in his later papers seldom mentions it again.

For a time I was content to believe that this local mastocytosis merely reflects the increased and continuing fibroblastic activity in the dermis, as in 
chronic inflammation elsewhere. Yet when I came to implant some of the carcinogens directly into the dermis the mast-cell reaction was distinctly less than when the carcinogen reached the dermis by way of the overlying epidermis. The inference is that something in the epidermis is responsible for the dermal changes, including the mast-cell reaction. Cortisone can largely suppress the dermal reaction to a surface carcinogen, though intra-epithelial tumours may still arise (Gillman et al, 1955). However, should a papilloma develop despite the administration of cortisone, it is accompanied by the usual mast-cell reaction in the dermis (Engelbreth-Holm and Zachariae, 1953).

Recently we have uncovered fresh facts which go some way towards explaining both the mast-cell reaction and the golden-brown fluorescence.

At the Histamine Symposium (April 1954) I stated in discussion that $\mathbf{I}$ thought it unlikely that mast cells, in general, contain substances other than histamine which act on plain muscle; thus, the published data concerning the topographical distribution of 5-hydroxytryptamine $(5-\mathrm{HT})$ did not then seem to fit the pattern shared in common by the mast cells and histamine. Shortly afterwards we ourselves examined several of the types of specimen which had proved so useful in clinching the mast cell-histamine hypothesis, e.g. ox liver capsule, mast-cell tumours from dogs and cattle, urticaria pigmentosa from man. All were negative for 5-HT or contained only the merest traces.

However, as Benditt (1955) and others have shown, 5-HT is present in the mast cells of two species, the mouse and rat. Moreover, it seems that 5-HT is also present in the epidermis of these two species (West and Parratt, 1957).

In order to demonstrate 5-HT in the mast cells, Miss Cass, Dr. Marshall and I examined selected tissues from both rat and mouse. Our point was to use tissues remote from either gut or epidermis, lest the mast cells be contaminated by 5-HT from some other source (Cass et al, 1958).

For the rat, we chose the metaphyses of the long bones which normally have no mast cells, but which acquire them in great numbers in parallel with the development of a triple syndrome of decalcification-rickets-osteitis fibrosa, induced by dietetic means (Urist and McLean, 1957; and see Figs. 64, 65). Briefly, our results were in agreement with the claims of Benditt: 5-HT and mast cells appeared together in the bones, as of course did histamine and the mast cells.

For the mouse, we first used dermal scrapings from skin treated with a carcinogenic hydrocarbon, despite the legitimate objection that such a tissue is close to epidermis which may itself contain 5-HT. Any doubts regarding the significance of the result were settled when we obtained from Dr. Jacob Furth of Boston, a sample of a transplantable mouse mast-cell tumour, recently isolated by him from a group of mice which had been subjected to ionizing radiation. So high were the values for histamine, heparin and 5-HT in the 


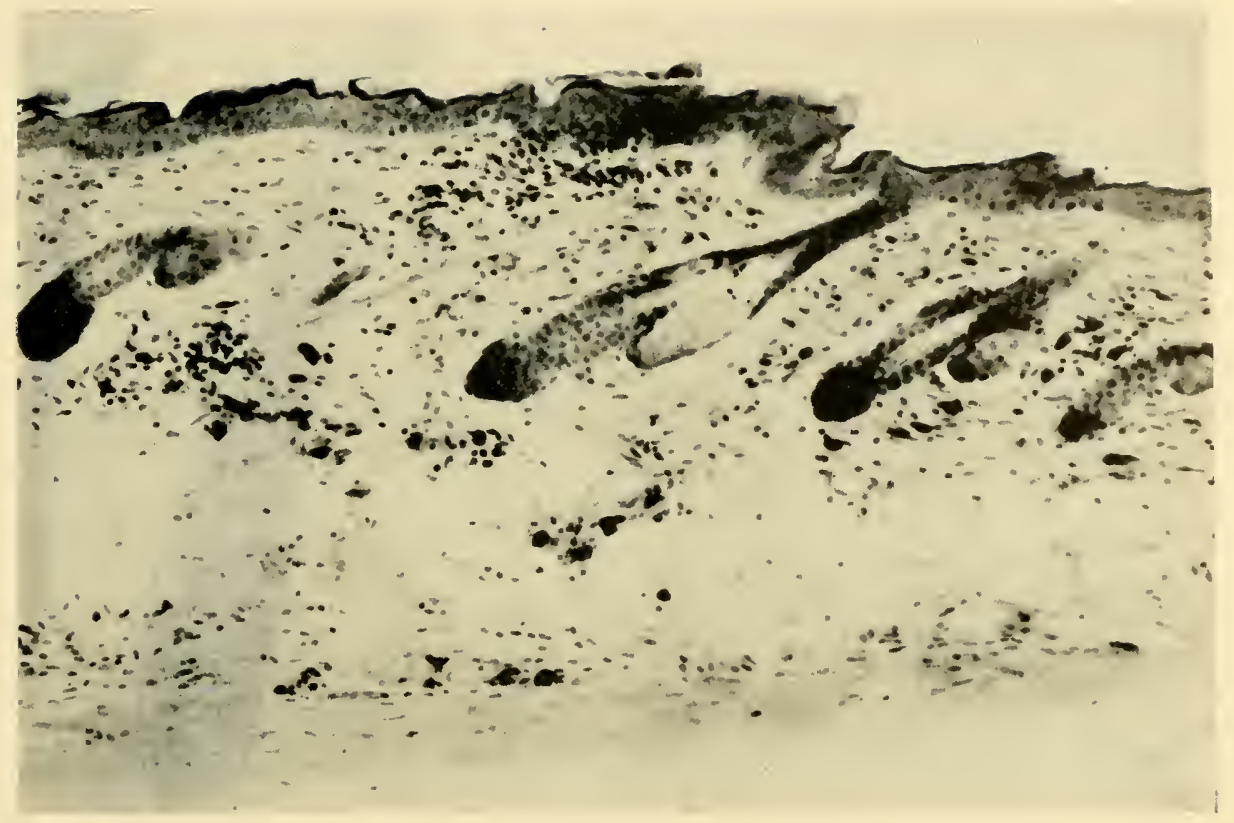

FiG. 61

Paraffin section, normal mouse skin, stained eosin-toluidine blue $(\times 140)$. The mast cells (dark spots) are seen at the level of the hair follicles and again, more deeply, close to the muscle. The epidermis is but 2 to 3 cells thick.

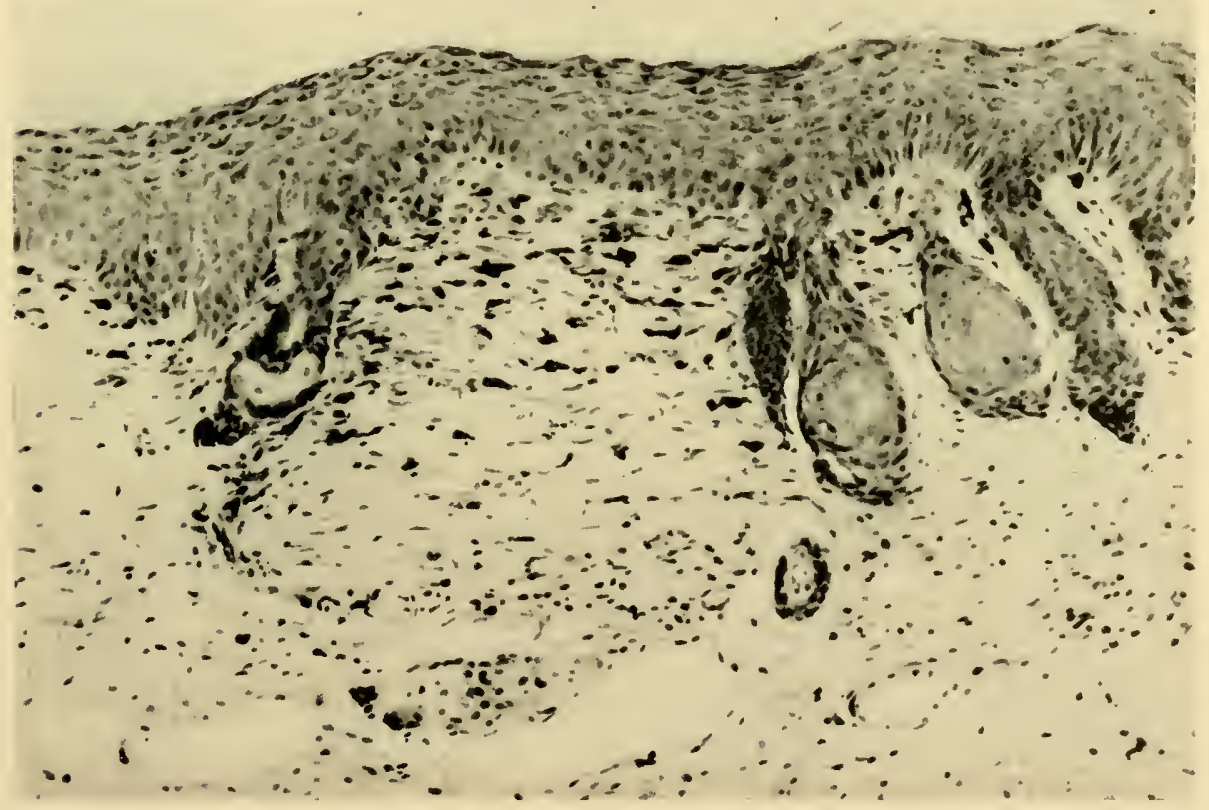

FiG. 62

Mouse Skin one month after a single massive painting with a carcinogenic hydrecarbon in a non-irritant solvent. The epidermis is now many cells thick, the sebaceous glands have gone and the hair follicles are clubbed and distorted. Note the numerous small mast cells which are appearing under the hyperplastic epidermis. Eosin-toluidine blue $(\times 160)$. 


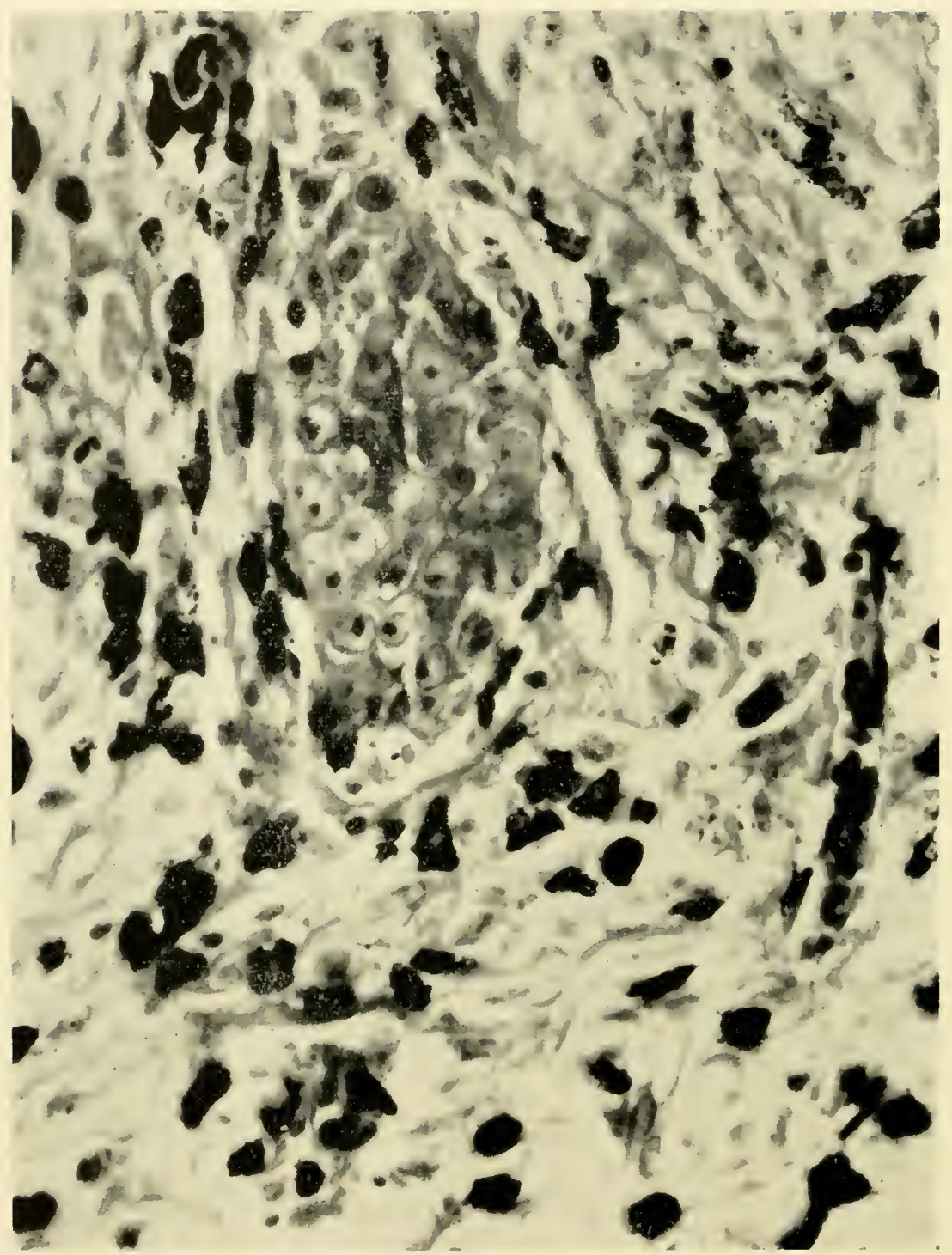

Fig. 63

High power view of the intense mast-cell reaction which has developed around a focus of precancerous epithelial cells situated near the edge of a large papilloma three months after painting the mouse skin with a potent carcinogen. Following fixation of the tissue in formaldehyde, such mast cells may show a golden-brown fluorescence in ultra-violet light. Toluidine blue $(\times 550)$. 


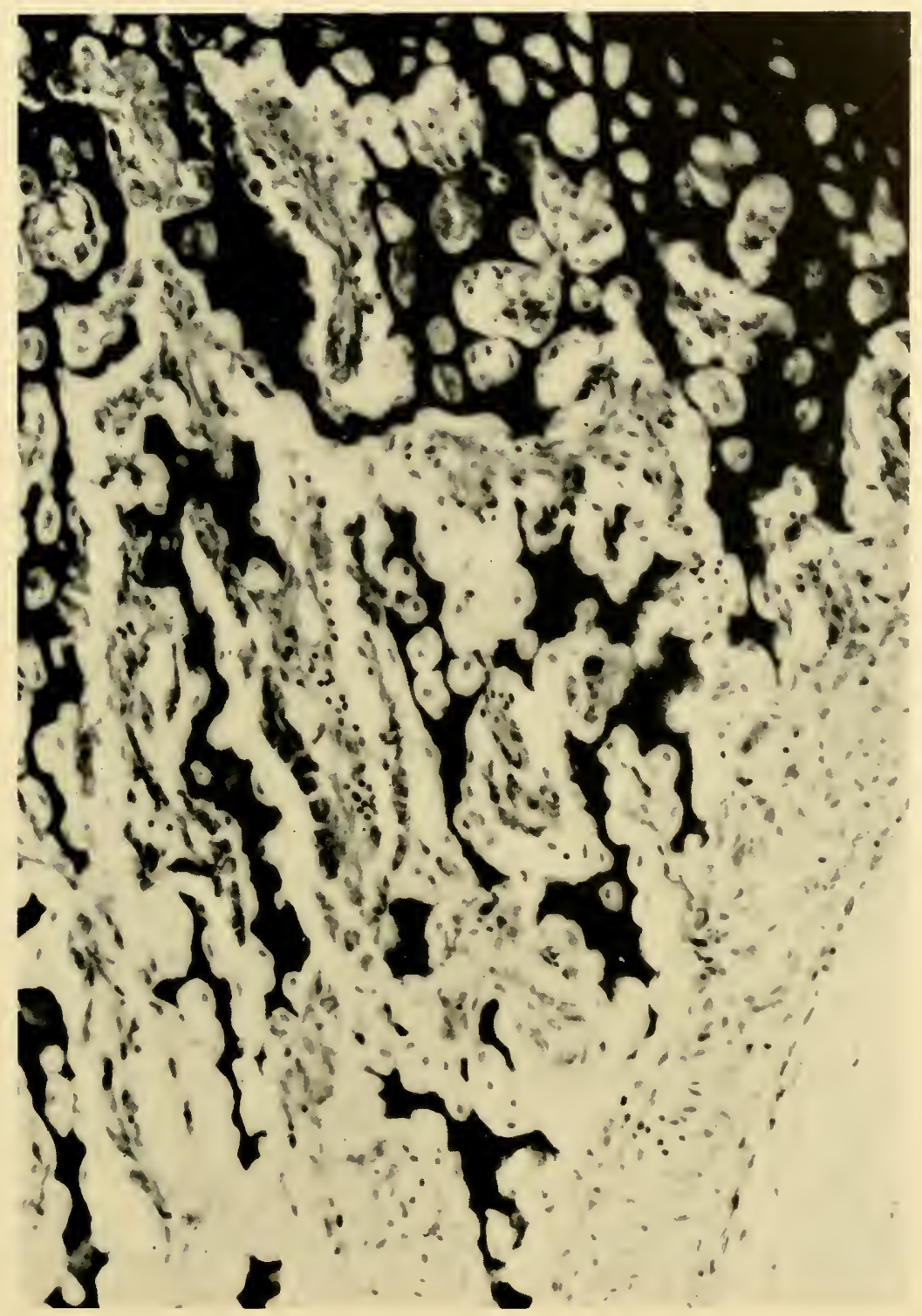

F1G. 64

Section through metaphyseal region of the tibia of a normal rat, stained toluicine blue $(\times 175)$. Dark metachromatic columns of cartilage but no mast cells. 


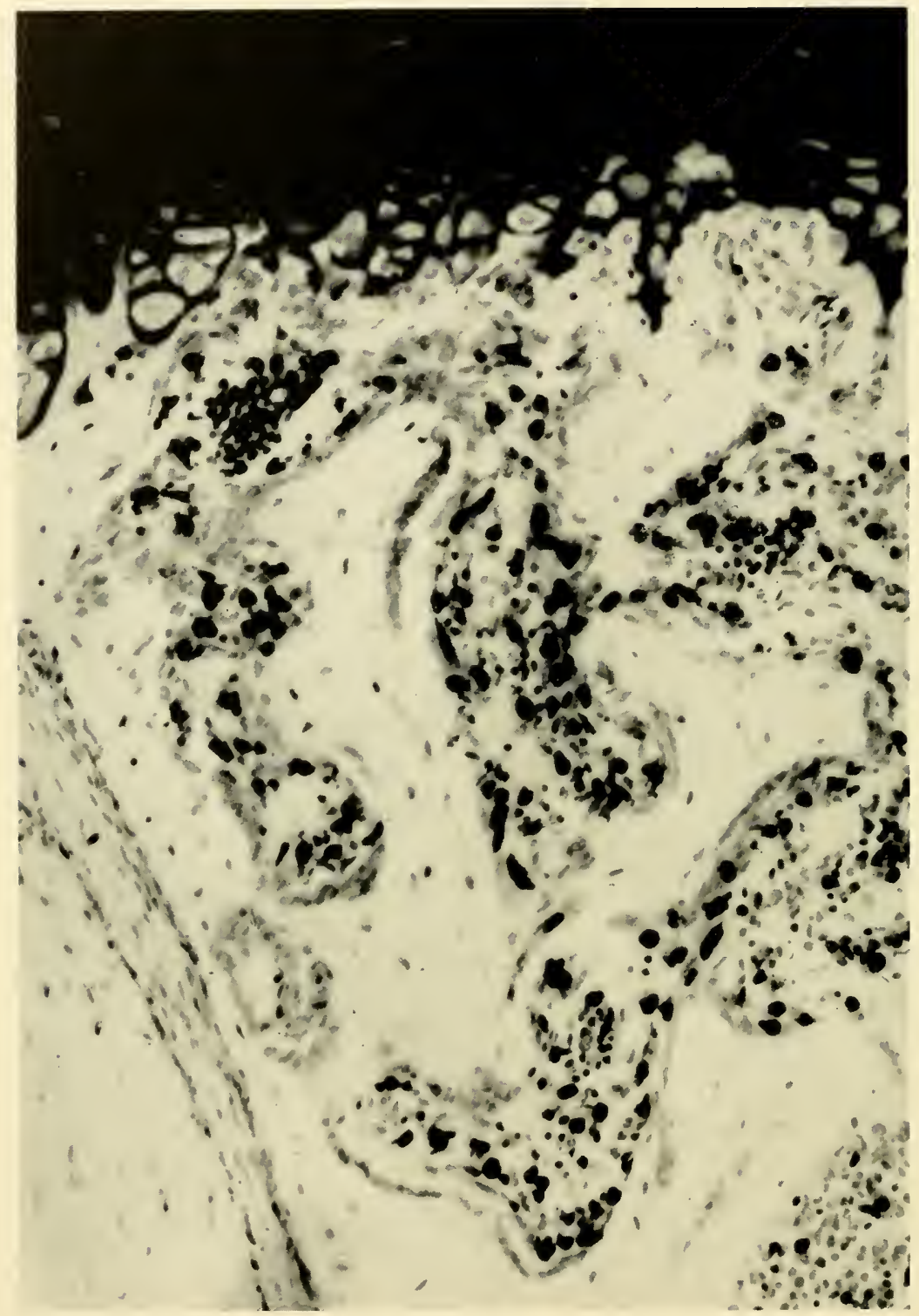

FIG. 65

Similar section to that shown in Fig. 64, taken from a rat fed for two months on a diet deficient in calcium and vitamin-D. There is now evidence of rickets, osteoporosis and osteitis fibrosa, together with a dramatic increase in the mast-cell content of the region. There is a corresponding increase in histamine and 5-hydroxytryptamine. 
tumour that my attention was distracted for the time being from our previous finding of an unusually high 5-HT content in the dermis of precancerous mouse skin. Biological assay for 5-HT in all the material was confirmed by chromatography of tissue extracts. On carrying out one of the routine tests for 5-HT on paper (examination in ultra-violet light following treatment of the spot with formaldehyde) I was confronted with the same kind of goldenbrown fluorescence that I had seen, years before, in the mast cells of precancerous mouse skin. At that time I had followed the method recommended by Cramer and Simpson (1944) which includes a preliminary fixation of the skin in 10 per cent formaldehyde prior to cutting frozen sections. If no formaldehyde is used no fluorescence develops. Moreover, much of the precursor substance responsible for the fluorescence in the skin can be extracted from the mast cells by a prolonged immersion of the tissue in acetone (Riley, 1958b). This is the method used for the extraction of 5-HT. According to Barter and Pearse (1955) the fluorescent substance itself (which is normally demonstrable only in the cells of the enterochromaffin system) is a $\beta$-carboline derivative of $5-\mathrm{HT}$. in which a third ring is formed through cyclization of the side chain.

The histological appearances suggest that the abnormally high concentration of 5-HT in the dermal mast cells of precancerous mouse skin may be derived, directly or indirectly, from the hyperplastic epidermis itself, and more especially from the epithelial cells of the abnormal hair follicles which have borne the brunt of the initial application of the carcinogen. Further, I believe it is from such cells that many of the malignant epitheliomas ultimately arise. The full significance of this interesting reaction in the skin of mice has yet to be determined (Riley, 1959). 


\section{GENERAL DISCUSSION: FUNCTIONS OF THE TISSUE MAST CELLS}

E IGHTY years have now passed since Ehrlich first clearly described and named the tissue mast cells, and we are still far from understanding their biological significance in the organism. Ehrlich himself believed that the mast cells are concerned in some way with the nutrition of the connective tissues. None of the twenty-five hypotheses listed sixty years later by Michels (1938) entirely supplanted this first attempt to endow the mast cell with a specific function.

However, in that same year (1937) Scandinavian workers succeeded in tracing heparin to the mast cells, a discovery which was widely accepted as the final answer to Ehrlich's 'riddle'.

Briefly, the Scandinavians based their new hypothesis on two main premises, both of which deserve the most careful scrutiny. These are first, the assumption that the heparin which they succeeded in extracting chemically from dog liver (hence Howell's choice of the name, 'heparin') or from other tissues rich in mast cells is the natural anticoagulant of the circulating blood; second, that the perivascular distribution, so characteristic of the mast cells, likewise indicates a haemic function, in this case, the prevention of intravascular thrombosis by the secretion of anticoagulant through the vessel wall.

Certainly, the first premise seemed to derive formidable support from the finding that heparin does escape from the dog's liver into its blood in peptone and in anaphylactic shock. This led to the further assumptions, $(a)$ that the conditions of peptone shock merely exaggerate a normal state of affairs (i.e. that a pathological process is an extension of a physiological process) and $(b)$ that the dog is characteristic of other animal species with respect to the function of its mast cells. It was unfortunate that the original investigation did not compare conditions in the dog with those in the cat, guinea pig or rat. Instead there came to be constructed an inverted pyramid of reasoning, founded on the findings in a single species and upon a pathological condition which has no known counterpart elsewhere. It will be recalled that we found very low heparin values in cat mastocytomas in which the granules are brilliantly metachromatic and in which the histamine values are often very high indeed; and we could obtain no evidence of a release of heparin into the blood of rats. Other workers have likewise failed to detect changes in blood coagulation either in experimental animals or in patients with widespread urticaria pigmentosa. Whereas heparin is present in many tissues and organs, there is 
little evidence that heparin is a normal constituent of blocd. Even a study of the histological relationship of mast cells to blood vessels in the rat led me to conclude that the mast cells fulfil their cycle in the connective tissues and do not secrete their contents directly into the blood stream.

It was thus the more fortunate that I first encountered the tissue mast cell, not in relation to the effects of heparin on the blood, but in a connective tissue reaction in the skin of mice treated with a carcinogen. This led to a search for a tissue function of the mast cell and to the study of the few conditions then known in which the mast cell appears to be involved. Such conditions seemed to have little enough in common, except, perhaps, the participation of histamine: it was this that led to the present enquiry and to the discovery that the tissue histamine resides in the same cell as the tissue 'heparin', a finding which has since been abundantly confirmed elsewhere (Mota et al, 1954; Benditt et al, 1955; Graham et al, 1955; Wegelius et al, 1955; Arvy et al, 1956; AsboeHansen and Wegelius, 1956; Keller and Burkard, 1956; Werle and Amman, 1956; Hill, 1958). Other workers have shown that much of the histamine in blood, at least in man, is likewise contained in the blood mast cells, or basophils (Graham et al, 1955; Code and Mitchell, 1954, 1957). The eosinophil, once thought to be the main carrier of histamine, appears to be more concerned with the detoxification and disposal of tissue histamine than with its elaboration (Ehrich, 1953; Samter, 1953; Vaughn, 1953; Vercauteren, 1953; Archer, 1956). We have often seen eosinophils in our material, but generally in situations in which histamine is being released from mast cells.

It may be useful in summing up the present work to comment briefly on the ground that has been covered, using the same numerical division of the matter as in the text:-

In Part I, a preliminary survey of the tissue mast cells in organisms of increasing complexity confirms Ehrlich's view that the cells with basophilic, metachromatic granules (his 'Mastzellen') are healthy, functioning cells of the connective tissues. In certain primitive species mast cells are present before the necessity for a blood vascular system has arisen. Fibroplasia, normal or pathological, is consistently followed by the development of tissue mast cells.

In Part II, a brief introduction (1) sets out the reasons for my own growing belief that the mast cell is more concerned with events in the tissues than in the blood, and that the mast cells may play a part in the release of histamine.

2. Detailed examination of the distribution of mast cells in the ox and rat, using the method of tissue spreads, emphasizes the enormous numbers of mast cells in the serous membranes, as well as around small blood vessels; even the perivascular mast cells seem to move away from the vessels as the cells mature. Mast cells are always to be found in young vascular connective tissue undergoing fibrillogenesis. 
3. Next, the effect on the mast cells of a group of substances, whose common property is an ability to release histamine, is examined. All cause swelling, degranulation and even disruption of the mast cells. The action of some of these substances (e.g. stilbamidine) can be followed under the microscope by taking advantage of their fluorescence in ultra-violet light.

4. The hypothesis that the mast cells themselves contain the histamine which is released is put to direct test by measuring histamine values in a series of normal tissues of widely differing mast-cell content. A strongly positive correlation is observed throughout. Ox liver capsule and ox visceral pleura are especially rich in mast cells and histamine. A method for determining the histamine content of the individual mast cell in ox liver capsule is described.

5. Exceptionally high values for histamine are found in certain pathological tissues rich in mast cells. Urticaria pigmentosa in man and mast-cell tumours from domestic animals all yield exceedingly high values, sometimes measurable in milligrams of histamine per gram of tissue examined. It is now the heparin (measured as anticoagulant) which occasionally fails to show a correspondingly high value, as, for example, in mast-cell tumours from cats.

6. At this point in the present investigation a more specific histamineliberator became available, Compound 4880 . Its effects were therefore studied on the mast-cell and histamine contents of a variety of tissues in the rat. Once the histamine has been completely released, Compound 48/80 is no longer toxic to the rat: long-term study of its effects is thus possible.

7. However, when Compound 48/80 is given to mice, not more than about half the available histamine can be liberated; higher doses are toxic and kill the mice from causes unconnected with the release of histamine. Evidently there are differences in the structure and composition of the mast cells, even among closely allied species.

8. This raises the question of the means whereby histamine is bound in the mast cell. Attention is drawn to the similarity of the reactions of the mast cell and of the myelin of nerve sheaths: both swell in water and in hypotonic solutions, especially in the presence of alkali. The chemical histamine-liberators are also bases and cause swelling of the mast cells. An enquiry into the efficiency with which trichloracetic acid extracts histamine from tissue samples adds further to the belief that histamine exists in the mast cells, preformed and ready for release, held only by loose ionic forces within a phospholipid membrane. Normally the histamine in the granule is part of a loose complex containing also heparin and proteins rich in basic amino-acids. When tissues of high mastcell content, or the isolated mast granules from rats, are analysed by paper chromatography it is found that they contain phosphatidyl choline (lecithin) and comparatively large amounts of phosphatidyl serine. The granules from rats also contain phosphatidyl ethanolamine. These phosphatides may 
constitute a 'trigger' which enables histamine to escape from the intact granule or cell. According to Uvnäs, a chemical histamine-liberator removes an inhibitor from a lecithinase at the mast-cell membrane. It is suggested that if this should prove to be a Type-C lecithinase there would be formed a primary phosphatide permeable to histamine and alcohols varying quantitatively and qualitatively from one species of mast cell to another. At the same time it is emphasized that the classical histamine-liberators produce pathological effects and that under normal circumstances it may be possible to release histamine without accompanying morphological changes in the mast cell.

9. Not all histamine is held in mast cells and responds to the action of the chemical histamine-liberators. The pyloric mucosa has a high histamine content, though it is poor in mast cells. The histamine value of rat pyloric mucosa actually rises as histamine is released from mast cells elsewhere.

10. The function of heparin, the second major component of the mast granule, is next examined and an hypothesis is suggested to account for the rapid release of heparin into the blood of the dog during peptone shock. The shock organ of the dog is the liver, and the heparin which can be extracted from it is an exceptionally efficient anticoagulant. The dog is unique in that it has a direct pathway leading from shock organ to blood, the thoracic duct, which by-passes the connective tissues. Thoracic duct lymph quickly becomes incoagulable during peptone shock.

11. When comparable conditions in the rat are examined, no evidence can be found that active anticoagulant reaches the rat's blood as the mast cells are destroyed. In fact, much of the heparin remains trapped locally in the connective tissues. It is suggested that the natural function of the mast cell is to store and release mucopolysaccharides for the connective tissues. The carbohydrate precursor substance is formed mainly by fibroblasts (since fibroblastic activity normally precedes the appearance of mast cells) and becomes a temporary component of the intercellular ground substance. With the onset of fibrillogenesis, excess ground substance is broken down, rebuilt and stored in altered, sulphated form (heparin) in the granules of the tissue mast cells, whence it can later be released and be again ingested by cells of the connective tissues. This cyclic process begins and is widespread in the embryo, and recurs locally in the tissues in adult life in response to 'trauma' or an acute watery oedema. A massive release of the stored mucopolysaccharide, still sulphated, may result in its overflow into the blood and the consequent manifestation of its anticoagulant properties.

12. Much of the experimental work on histamine in the past concerned its effects on the skin. Mast cell-histamine 'profiles' of skin from man, cattle, cat, mouse and rat show a close relationship between their mast-cell and histamine contents. 
13. Finally, an enquiry is made into the mast-cell reaction in mouse skin undergoing carcinogenesis from repeated surface applications of a polycyclic hydrocarbon. Many of the mast cells under the painted skin show a goldenbrown fluorescence in ultra-violet light. This seems to be associated with a high content of 5-hydroxytryptamine, a normal constituent of the mast cells of the mouse and rat, though present in no other species. Work is in progress to trace the sources of this high content of 5-hydroxytryptamine and to determine its significance. Now that something is known of the structure and composition of the normal mast cell it may be possible to arrive at an understanding of the significance of the mastocytosis in precancerous mouse skin. It will be recalled that it was for this reason that the present work was begun. 


\section{BIBLIOGRAPHY}

An asterisk $\left({ }^{*}\right)$ denotes a book or a review article containing a useful bibliography.

Adams, S. S. (1953). The effects of anaphylactic and peptone shock on the coagulability of rabbit and guinea pig blood. J. Pharm. (Lond.) 9, 580-585.

AlfEJEW, S. (1924). Die embryonale Histogenese der Zellformen des lockeren Bindegewebes der Saugetiere. Folia haemat. (Lpz.) 30,111-116.

Al-HussainI, A. H. (1948). Alkaline phosphatase in fish gut. Nature (Lond.) 161, 274-275.

Al-Hussaini, A. H. (1949). On the functional morphology of the alimentary tract of some fish in relation to differences in their feeding habits: Cytology and Physiology. Quart. J. micr. Sci.90, 323-354.

ARCHER, G. T. (1958). Release of histamine from mast cells by tissue extracts. Nature (Lond.) 182, $726-727$.

ARCHER, R. K. (1956). The eosinophilic response in the horse to intramedullary and intradermal injections of histamine, ACTH and cortisone. J. Path. Bact. 72, 87-94.

Arvy, L. (1955a). Caractères histologiques du 'stratum granulosum' de Oppel chez la truite. C.R. Soc. Biol. (Paris) 149, 2131-2134.

Arvy, L. (1955b). Particularités histologiques des Labrocytes chez quelques Batraciens. C.R. Ass. Anat. XLII Réunion, 217-223.

*ARvy, L. (1955d). Les labrocytes (Mastzellen). Rev. hémat. 10, 55-94.

ARvy, L. (1956a). Action de doses répétées d'un dérivé de la méthylamine sur la richesse du tissue conjonctif et des ganglions lymphatiques en labrocytes chez le Rat. C.R. Soc. Biol. (Paris) 150, 2071-2074.

Arvy, L. (1956b). Histogénèse et répartition des labrocytes chez le Rat. C.R. Ass. Anat. XLIII Réunion 165-170.

Arvy, L., Halpern, B. N., \& Neveu, T. (1956). Modifications morphologiques des labrocytes et corrélations avec la mise en liberté de l'histamine endogène après injection d'une butylamine substitutive (1935 L) douée de propriétés histamino-libératrices chez le Rat. C.R. Soc. Biol. (Paris) 150, 2074-2078.

ARVY, L., \& Quivy, D. (1955a). Relation entre la richesse en labrocytes et la teneur en histamine des divers segments du tube digestif chez le Chien. C.R. Soc. Biol. (Paris) 149, 658-672.

Arvy, L., \& Quivy, D. (1955b). Données sur la répartition des labrocytes chez le Chien. C.R. Ass. Anat. XLII Réunion, 234-241.

Asboe-HAnsen, G. (1950). A survey of the normal and pathological occurrence of mucinous substances and mast cells in the dermal connective tissue in man. Acta dermat-venereol (Stock $h$.) 30, 338-347.

*Asboe-Hansen, G. (1951). Om Bindevaevets Mucinøse Substanser. Copenhagen: Rosenkilde \& Bagger.

*Asboe-Hansen, G. (1954). The mast cell. Int. Rev. Cytol. 33, 399-431.

Asboe-Hansen, G., \& Wegelius, O. (1956). Histamine and mast cells. Studies on living connective tissue in the hamster cheek pouch. Acta physiol. scaul. 37, 350-358.

Asplund, J., Borell, U., \& Holmgren, H. (1939). Untersuchungen über die Speicherung des Heparins im Tierorganismus sowie über seine Resorptionsmöglichkeiten in Darm und Placenta. Z. mikr.-anat. Forsch. 46, $16-67$.

Audry, C. (1896). Sur les cellules isoplastiques (Mastzellen). Ann. Derm. Syph. (Paris) 3, 9-22.

BAAR, H. S., \& BiCKEL, H. (1952). Cystine storage Disease with aminoaciduria and dwarfism (Lignac-Fanconi Disease). Acta paediat. (Uppsála) 42, Suppl. 90, 171-232.

BAEKELAND, E. (1950). Influence d'implants sanguins et fibrineux sur le nombre des mastocytes et tactisme de ces cellules. C.R. Soc. Biol. (Paris) 144, 1005-1007.

BaIRATI, A., JR., \& BianCHINI, A. (1953). Indagini istochimiche sui mucopolisaccaridi in embrioni umani ai primi mesi di vita. Boll. Soc. ital. Biol. sper. 29, 1880-1881.

BALI, T., \& FURTH, J. (1949). A transplantable splenic tumour rich in mast cells. Observations on mast cells in varied neoplasms. Amer. J. Path. 25, 605-625.

BALlowITZ, E. (1891). Über das Vorkommen der Ehrlichschen granulierten Zellen ('Mastzellen') bei winterschlafenden Säugetieren. Anat. Anz. 6, 135-142.

Barrnett, R. J., Hagen, P., \& LeE, F. L. (1958). Mast-cell granules containing 5-hydroxytryptamine, histamine and heparin, morphologically and biochemically distinct from mitochondria. Biochem J. 69, 36 P.

Barter, R., \& Pearse, A. G. E. (1955). Mammalian enterochromaffin cells as the source of serotonin (5-hydroxytryptamine). J. Path. Bact. 69, 25-31.

BATES, E. O. (1935). A quantitative study and interpretation of the occurrence of basophile (mast) cells in the subcutaneous tissue of the albino rat. Anat. Rec. 61, 231-239. 


\section{B I B LIOG RA PHY}

BÄUMER, E. (1896). Beiträge zur Histologie der Urticaria simplex und pigmentosa mit besonderer Berüksichtigung der Bedeutung der Mastzellen für die Pathogenese der Urticaria pigmentosa. Arch. Derm. Siph. (Berl.) 34, 323-348.

Beare, M. (1958). Urticaria pigmentosa and allied diseases. Brit. J. Dermatol. 70, 418-425.

Behrens, M., \& Taubert, M. (1952). Der Nachweis von Heparin in den basophilen Leukocyten. Klin. Wschr. 30, 76-78.

Bell, H. J., \& Jaques, L. B. (1956). Species differences in heparin. Bull. Soc. Chim. Belg. 65, 36-49.

Benacchio, G. B. (1911). Gibt es bei Meerschweinchen und Kaninchen Mastmyelocyten, und stamen die basophilgekörnten Blutmastzellen aus dem Knochenmark? Folia haemat. (Lpz.) 11, 253-269.

Benditt, E. P., BAder, S., \& LAm, K. B. (1955). Studies of the mechanism of acute vascular reactions to injury. 1. The relationship of mast cells and histamine to the production of edema by ovomucoid in rats. A.M.A. Aich. Path. 60, 104-115.

Benditt, E. P., Wong, R. L., Arase, M., \& Roeper, E. (1955). 5-hydroxytryptamine in mast cells. Proc. Soc. exp. Biol. (N.Y.) 90, 303-304.

Bensley, S. H. (1950). Histological studies of the reactions of cells and intercellular substances of loose connective tissue to the spreading factor of testicular extracts. Amm. N.Y. Acad. Sci. 52, 983-987.

Berg, N. O. (1951). A histochemical study of masked lipids. Stainability, distribution and functional variations. Acta. path. microbiol. scand. Suppl. 90.

BieRICH, R. (1922). Über die Beteiligung des Bindegewebes bei der experimentellen Krebsbildung.

Virchow's Arch. path. Anat. 239, 1-19.

Blomquist, H. E. (1956). Kann eine Anhäufung von Mastzellen im Grenzgebiet der Schilddrüsenadenome beobachtet werden? Acta path. microbiol. scand. 39, 313-316.

Bloom, F. (1942). Spontaneous solitary and multiple mast-cell tumours ("mastocytoma") in dogs. A.M.A. Arch. Path. 33, 661-676.

Bloom, G., \& Friberg, U. (1953). A method for the electronmicroscopy of tissue mast cells. Experientia (Basel) 9, 310.

Bloom, G., Friberg, U., Larsson, B., \& Åberg, B. (1955). Morphology of tissue mast cells in dog mastocytoma and clinical chemistry of these tumours. Acta path. microbiol. scand. 37, $163-166$.

Bloom, G., Dunér, H., Pernow, B., Winberg, J., \& Zetterstöm, R. (1958a). Spontaneous histamine shocks in urticaria pigmentosa. Acta paediat. (Uppsála) 47, 152-162.

Bloom, G., Larsson, B., \& ÅberG, B. (1958b). Canine mastocytoma. Zbl. Vet.-med. 5, $443-458$.

Bolton,L. L. (1933). Basophile (mast) cells in the Alimentary Canal of Salmonoid Fishes. J. Morph. $54,549-582$.

BONNEY, V. (1908). The connective tissue in carcinoma and in certain inflammatory states that precede its onset. Lancet 1, 1389-1393.

Bordet, J. (1913). Le Méchanisme de l'Anaphylaxie. C.R. Soc. Biol. (Paris) 74, 225-227.

Borrel, Boez, \& de Coulon (1923). Cancer du goudron chez la souris. C.R. Soc. Biol. (Paris) 88, 402-406.

Braunsteiner, H. von, Mitsotakis, E., \& Thumb, N. (1957). Über die Wirkung von Diaminodecan auf Mastzellen und basophile Leucozyten. Blut 3, 255-261.

* Bremy, P. (1950). Die Gewebsmastzellen im menschlichen Knochenmark. Stuttgart: Georg Thieme.

Brodersen, J. (1928). Die Zellen des Unterhautbindegewebes der weissen Maus. Z. mikr.-anat. Forsch. 14, 60-72.

BujARd, E. (1930). Une coloration strictement élective des granulations basophiles des mastocytes. Bull. Histol. Techn. micr. 7, 264-269.

Burkl, W. (1952). Über Mastzellen und ihre Aufgaben. Wien. klin. Wschr. 23, 411-415.

Cambel, P., Conroy, C. E., \& Sgouris, J. T. (1952). Gastric mast-cell diapidesis in the Albino rat. Science 115, 273-274.

Campan1, M. (1951). Function of mast cells. Lancet 1, 802.

Carter, P. B., Higginbotham, R. D., \& Dougherty, T. F. (1957). The local response of tissue mast cells to antigen in sensitized mice. J. Immmmol. 79, 259-264.

Cass, R., Marshall, P. B., \& Riley, J. F. (1958). 5-hydroxytryptamine and histamine in mast cells of the mouse and rat. J. Physiol. (Lond.) 141, 510-519.

Cass, R., Riley, J. F., West, G. B., Head, K. W., \& Stroud, S. W. (1954). Heparin and histamine in mast-cell tumours from dogs. Nature (Lond.) 174, 318-319.

Castor, C. W. (1957). Production of mucopolysaccharides by synovial cells in a simplified tissue culture medium. Proc. Soc. exp. Biol. (N.Y.) 94, 51-56.

*Cazal, P. (1942). Un nouvel aspect de la médicine tissulaire: les Réticulopathies, et le système réticulo-histiocytaire. Paris: Vigot.

Charles, A. F., \& Scott, D. A. (1933). Studies on heparin. 11. Heparin in various tissues. J. biol. Chem. 102, 431-435.

Clowes, G. H. A., \& OWEN, A. G. (1904). Metachromatism of mast-cell granules and mucin. J. Med. Res. 7, 407-431. 


\section{B I BLIOGRA PHY}

*Code, C. F. (1952). Histamine in blood. Physiol. Rev. 32, 47-65.

Code, C. F., \& Mitchell, R. G. (1954). The effect of cortisone on the number of circulating basophils and eosinophils: Is there a relationship between these cells? Proc. Mayo Clin. 29, $200-204$.

Code, C. F., \& Mitchell, R. G. (1957). Histamine, eosinophils and basophils in the blood. J. Physiol. (Lond.) 136, $449-468$.

Compton, A. S. (1952). A cytochemical and cytolocial study of the connective tissue mast cell. Amer. J. Anat. 91, 301-323.

Consolandi, G., \& Briziarelli, G. (1952). Le Mastzellen dell 'ipofisi umana. Lav. Ist Anat. Univ. Perugia 12, 21-55.

Constantinides, P. (1953). Mast cells and susceptibility to experimental atherosclerosis. Science $117,505-506$.

Corbetta, S. (1951). Distribuzione numerica dei mastociti nelle malattie gastriche. Arch. "De Vecchi Anat. patol. 17, 31-35.

Cornil, L., \& Michon, P. (1924). Sur la présence de Mastocytes dans les tumeurs cutanées de la maladie de Recklinghausen. C.R. Soc. Biol. (Paris) 91, 787-788.

Cotte, J. (1904). Contribution à l’étude de la nutrition chez les spongiaires. Bull. Soc. Fr. Belg. 38, 420-567.

*Cramer, W., \& Simpson, W. L. (1944). Mast cells in experimental carcinogenesis. Cancer Res. 4, $601-616$.

Cúnot, L. (1905). L’orgagne phagocytaire des crustacés decapodes. Arch. Zool. exp. Gén. 3, $1-13$.

Curran, R. C. (1957). The elaboration of mucopolysaccharides by vascular endothelium. J. Path. Bact. 74, 347-352.

DALE, H. H. (1929a). Some chemical factors in the control of the circulation. Lecture 1I. Local vasodilator reactions-Histamine. Lancet 1, 1233-1237.

Dale, H. H. (1929b). Some chemical factors in the control of the circulation. Lecture III. Local vasodilator reactions-Histamine-Acetyl Choline-Conclusion. Lancet 1, 1285-1290.

DALE, H. H. (1950). The action and uses of the antihistamine drugs as applied to dermatology. Brit. J. Derm. 62, 151-158.

*Dale, H. H. (1954). The mechanism of anaphylaxis, in: An Alttumn Gleaning, pp. 199-211. London: Pergamon Press.

DantschakofF, V. (1916). The wandering cells in the loose connective tissue of the bird and their origin. Anat. Rec. 10, $483-492$.

Dawson, R. M. C. (1957). The animal phospholipids: their structure, metabolism and biological significance. Biol. Rev. 32, 118-229.

Deringer, M. K., \& DunN, T. B. (1947). Mast-cell neoplasia in mice. J. nat. Cancer Inst. 7, 289-297.

DeUel, H. J., JR. (1951). The Lipids (Vol. I). London \& New York: Interscience Publishers.

DE ViÑals, R. R. (1931). Les 'mastzellen' dans le cancer expérimental de la souris blanche. C.R. Soc. Biol. (Paris) 108, 177-179.

DE VIÑals, R. R. (1954). Celulas cebadas tisulares (heparinocitos) en los organos hematopoyeticos. Folia clin. int. (Barcelona) 4, 471-474.

Doan, C. A., \& Reinhart, H. L. (1941). The basophil granulocyte, basophilocytosis, and myeloid leukaemia, basophil and 'mixed Granule' types; an experimental, clinical and pathological study, with a report of a new syndrome. Amer. J. Clin. Path. 11, 1-33.

Downey, H. (1909). The lymphatic tissue of the kidney of Polyodon spathula. Folia haematol. 8, 415-463.

DowneY, H. (1914). Heteroplastic development of eosinophil leucocytes and of hematogenous mast cells in bone marrow of guinea pig. Anat. Rec. 8, 135-137.

Dreifuss, W., \& Bloch, B. (1922). Über die künstliche Erzeugung von metastasierenden Maüsecarcinom durch Bestandteile des Teerpeches. Klinische und histologische Untersuchungen. Arch. Derm. 140, 6-63.

Drennan, J. M. (1951). The mast cells in urticaria pigmentosa. J. Path. Bact. 63, 513-520.

Drennan, J. M., \& Beare, J. M. (1954). Solitary mast-cell naevus. J. Path. Bact. 68, 345-356.

Drinker, C. K., \& YOFFEY, J. M. (1941). Lymphatics, lymph and lymphoid tissue (p. 309), Cambridge, Mass.

Drury, A. N. (1914). The eosinophil cell of the teleostean fish. J. Physiol. (Lond.) 49, 349-365.

Drzewina, A. (1905). Contribution à l'étude du tissu lymphoïde des Ichthyopsidés. Aich. Zool. Exp. Générale 3, 145-323.

Duguid, J. P., Smith, I. W., \& Wilkinson, J. F. (1954). Volutin production in 'bacterium aerogenes' due to development of an acid reaction. J. Path. Bact. 67, 289-300.

DunN, T. B. (1954). Normal and pathologic anatomy of the reticular tissue in laboratory mice, with a classification and discussion of neoplasms. J. nat. Cancer Inst. 14, 1281-1378.

Dunn, T. B., \& Potter, M. (1957). A transplantable mast-cell neoplasm in the mouse. J. nat. Cancer Inst. 18, 587-601. 


\section{BIBLIOGRAPHY}

Duthie, E. S. (1939). The origin, development and formation of the blood cells in certain marine teleosts. Part 1, Morphology. J. Anat. (Lond.) 73, 396-410.

Efrati, P. E., Klajman, A., \& Spitz, H. (1957). Mast-cell leukaemia? Malignant mastocytosis with leukaemic manifestations. Blood 12, 869-882.

EHRICH, W. E. (1953). Histamine in mast cells. Science 118, 603.

Ehrich, W. E., Seifter, J., Alburn, H. E., \& Begany, A. J. (1949). Heparinocytes in elephantiasis scroti. Proc. Soc. Exper. Biol. (N.Y.) 70, 183-184.

EhrlıC, P. (1877). Beiträge zur Kenntnis der Anilinfärbungen und ihrer Verwendung in der mikroskopischen Technik. Arch. mikr.-Anat. 13, 263-277.

*Ehrlich, P. (1956). Contributions to the theory and practice of histological staining (Inaugural Dissertation University of Leipzig, 1878). In: The Collected Papers of Paul Ehrlich. Ed. Himmelweit, F. Vol. 1, pp. 65-98, Histology, Biochemistry and Pathology. London \& New York: Pergamon Press.

Ehrlich, P. (1879). Beiträge zur Kenntnis der granulierten Bindegewebszellen und der eosinophilen Leukocyten. Arch. Anat. Physiol. (Lpz.) 3, 166-169.

Ehrlich, P. (1891). Farbenanalytische Untersuchungen zur Histologie und Klinik des Blutes. Berlin: Hirschwald.

Ehrlich, P., \& Lazarus, A. (1898). Die Anämie, vol. 1. Normale und pathologische Histologie des Blutes. Wien: Hölder. (Revised and Republished, 1909.)

Ellis, J. M. (1949). Urticaria pigmentosa. A report of a case with autopsy. Arch. Path. 48, 426-435.

Englebreth-Holm, J., \& Asboe-Hansen, G. (1953). Effect of cortisone on skin carcinogenesis in mice. Acta path. microbiol. scand. 32, 560-564.

Ernst, T. (1926). Über die ersten Stunden der Entzündung. Beitr. path. Anat. 75, $229-258$.

FABris, A. (1927). Mastocitomi cutanei da catrame. Pathologica 19, 157-166.

FADEM, R. S. (1951). Tissue mast cells in human bone marrow. Blood 6, 614-630.

FAvilli, G. (1950). Some Italian contributions to the problems concerning mesomucinase (Hyaluronidase) and mucopolysaccharides of connective tissues. Sci. med. ital. 1, 403-428.

FAWCETT, D. W. (1954). Cytological and pharmacological observations on the release of histamine by mast cells. J. Exp. Med. 100, 217-224.

FAWCETT, D. W. (1955). An experimental study of mast-cell degranulation and regeneration. Anat. Rec. 121, 29-52.

Feinberg, S. M., \& Sternberger, L. A. (1955). Action of histamine-liberator compound 48/80 in the guinea pig. J. Allergy 26, 170-179.

*FeldberG, W. (1954). On some physiological aspects of histamine. J. Pharm. (Lond.) 6, 281-301.

FeldberG, W., \& Harris, G. W. (1953). Distribution of histamine in the mucosa of the gastrointestinal tract of the dog. J. Physiol. (Lond.) 120, 352-364.

FeldberG, W., \& Miles, A. A. (1953). Regional variations of increased permeability of skin capillaries induced by a histamine-liberator and their relation to the histamine content of the skin. J. Physiol. (Lond.) 120, 205-213.

FeldBerG, W., \& SMITH, A. N. (1953). Release of histamine by tryptamine and 5-hydroxytryptamine. Brit. J. Pharmacol. 8, 406-411.

FeldberG, W., \& Talesnik, J. (1953). Reduction of tissue histamine by compound 48/80. J. Physiol. (Lond.) 120, 550-568.

Fell, H. B., \& Danielli, J. F. (1943). The enzymes of healing wounds. I. The distribution of alkaline phosphomonoesterase in experimental wounds and burns in the rat. Brit. J. exp. Path. 24, 196-202.

Ferrata, A. (1912). Morphologia de Sangue normale et Pathologico. Milan: Soc. edit. libraria.

Fish, H. S. (1949). Morphogenesis of rat connective tissue during the first ten days of life. Anat. Rec. 103, 451 .

Forkner, C. E. (1929). Blood and bone marrow cells of the domestic fowl. J. exp. Med. 50, 121-141.

Frey-Wyssling, A. (1948). Subnicroscopic Morphology of Protoplasm and its Derivatives. New York: Elsevier.

*Friberg, U., Graf, W., \& ÅberG, B. (1951). On the histochemistry of the mast cells. Acta. path. microbiol. scand. 29, 197-201.

Friedman, B. I., Will, J. J., Freiman, D. G., \& Braunstein, H. (1958). Tissue mast-cell leukaemia. Blood 13, 70-78.

Fromme (1906). Demonstration über das Verhalten der Mastzellen beim Karzinom. Zbl. Gyäak. 30, $1146-1147$.

*Fulton, G. P., Maynard, F. L., Riley, J. F., \& West, G. B. (1957). Humoral aspects of tissue mast cells. Physiol. Revs. 37, 221-232.

Furth, J., Hagen, P., \& Hirsch, E. I. (1957). Transplantable mastocytoma in the mouse containing histamine, heparin, 5-hydroxytryptamine. Proc. Soc. exp. Biol. (N.Y.) 95, 824-828.

Further, H. (1913). Beiträge zur Kentniss der Vogellymphknoten. Z. Naturw. 50, 359-409. 


\section{BIBLIOGRAPHY}

Gebauer-Fuelnegg, E., Dragstedt, C. A., \& Mullenix, R. B. (1932). Observations on a physiologically active substance appearing during anaphylactic shock. Proc. Soc. Exp. Biol. (N.Y.) 29, 1084.

GicklhoRN, J. (1932). Intracelluläre Myelinfiguren bei der reversiblen Entmischung des Protoplasmas. Protoplasma 15, 90-108.

Gillman, T. (1958). Mast-cell increases after calciferol intoxication and in experimental odoratism. Acta haemat. (Basel) 19, 179-186.

Gillman, T., Penn, J., Bronks, D., \& Roux, M. (1955). Influence of cortisone on connective tissue-epithelial relations in wound healing, hair regeneration and the pathogenesis of experimental skin cancers. Nature (Lond.) 176, 932-933.

Graham, H. T., Wheelwright, F., Parish, H. H., Jr., Marks, A. R., \& Lowry, O. H. (1952). Distribution of histamine among blood elements. Fed. Proc. 11, 350.

*Graham, H. T., Lowry, O. H., Wahl, N., \& Priebat, M. K. (1955). Mast cells as sources of tissue histamine. J. exp. Med. 102, 307-317.

Gray, J. H. (1935). Preliminary note on the mast cells of the human pituitary and of the pituitary in general. J. Anat. (Lond.) 69, 153-158.

GreENE, C. W. (1912). Anatomy and histology of the alimentary tract of the king salmon. Bull. U.S. Bur. Fish. 32, 75-97.

GreGgIO, H. (1911). Les cellules granuleuses (Mastzellen) dans les tissus normaux et dans certains maladies chirurgicales. Arch. Méd. exp. 23, 323-375.

Greig, W. A. (1950). A possible mast-cell tumour from a cow. Demonstration, Path. Soc. G. Britain and Ireland. Dundee Meeting.

Grossberg, A. L., \& Garcia-Arocha, H. (1954). Histamine liberation in vitro and mode of binding of histamine in tissues. Science 120, 762-763.

Grossfeld, H., Meyer, K., \& Goodman, G. (1955). Differentiation of fibroblasts in tissue culture, as determined by mucopolysaccharide production. Proc. Soc. Exp. Biol. (N.Y.) 88, 31-35.

Guilliermond, A., \& MARvas (1908). Caractères histo-chimiques des granulations des mastzellen et rapport de ces corps avec la volutine des protistes. C.R. Soc. Biol. (Paris) 64, 307-309.

Gustafsson, B. E., \& Cronberg, S. (1957). Comparison of the effects of compound 48/80, protamine and turpentine oil on mast-cell degranulation. Acta rheum. scand. 3, 189-202.

Häckel, E. (1857). Über die Gewebe des Flusskrebs. Arch. Anat. Physiol. wiss. Med. 469-566.

Hagen, P. (1954). The intracellular distribution of histamine in dog's liver. Brit. J. Pharmacol. 9, $100-105$.

Hagen, P., \& LeE, F. L. (1958). Amino acid decarboxylases of mouse mast cells. J. Physiol. (Lond.) 143, 7 P.

Hamilton, T. R., \& Syverton, J. T. (1950). Tissue mast cells with Anitschkow nuclei: investigations into cytologic bases of rheumatic processes. Amer. J. Path. 26, 705-706.

Hardy, W. B. (1892). The blood-corpuscles of the crustacea, together with a suggestion as to the origin of the crustacean fibrin-ferment. J. Physiol. (Lond.) 13, 165-187.

Hardy, W. B., \& Wesbrook, F. F. (1895). The wandering cells of the alimentary canal. J. Physiol. (Lond.) 18, 490-523.

Harris, H. F. (1900). Histology and microchemic reactions of some cells to anilin dyes-identity of the plasma-cell and osteoblast-fibrous tissue a secretion of the plasma-cells-mast cell elaborates mucin of connective tissues. Philad. Med. 5, 757-764.

*Head, K. W. (1958). Cutaneous mast-cell tumours in the Dog, Cat and Ox. Brit. J. Dermatol. 70, 389-408.

Head, K. W. (1953). Neoplastic diseases (in, Symposium on Skin Diseases encountered in Veterinary Practice). Vet. Rec. 65, 926-928.

Head, K. W., West, G. B., Stroud, S. W., \& Riley, J. F. Multiple mast-cell lesions in a cow. To be published.

Hedbom, A., \& Snellman (1955). Isolation and analysis of the large cytoplasmic granules of tissue mast cells. Exp. Cell Res. 9, 148-156.

Heller, J. (1904). Ein Beitrag zur Genese der Mastzellen der Haut. Dtsch. med. Wschr. 30, $507-509$.

Henschen, F., discussion to Quensel, U. (1928). Acta path. microbiol. scand. 5 (Supplement), 34-38.

Hermann, H. (1952). Über die Bedeutung der Mastzellen in sympathetischen Ganglien. Klin. Wschr. 30, 87.

Higginbotham, R. D., Dougherty, T. F., \& JeE, W. S. S. (1956). Fate of shed mast-cell granules. Proc. Soc. exp. Biol. (N.Y.) 92, 256-261.

Higuchi, K. (1930). Die Gewebsmastzellen in der Mamma. Folia haematol. 41, 401-414.

Hill, M. (1957). Morphological effects of the secretion of histamine and mucopolysaccharides by mast cells. Experientia 13, 395.

Hill, M. (1958), Über den Einfluss experimentaler Schockbedingungen auf die Mastzellen. Acta anat. 35, 118-131. 


\section{B I B LIOGRA PHY}

Hirt, R., \& Berchtold, R. (1952). Biophysikalische Studien mit Tensiometer. ArzneimittelForsch. 2, 453-455.

Hissard, R., Moncourier, L., \& JACQuet, J. (1950a). Une nouvelle affection hématodermique, la mastocytose. C.R. Acad. Sci. 231, 253-255.

Hissard, R., Moncourier, L., \& Jacquet, J. (1950b). A propos d'un cas de mastocytose pure. Origine et evolution des mastocytes. C.R. Acad. Sci. 231, 1178-1179.

Huelmian, G. (1954). Über das erste Auftreten der Mastzellen in einigen Geweben und Organen bei Homembryonen mit Berücksichtigung der Zunahme dieser Zellen wahrend der Embryonalentwicklung. Comment. Biol. Helsingf. 132, 1-53.

HögBerg, B., \& UvNäs, B. (1957). The mechanism of the disruption of mast cells produced by compound 48/80. Acta. phisiol. scand. 41, 345-369.

HöGBERG, B.. \& UvNÄs, B. (1958). Inhibitory action of Allicin on degranulation of Mast Cells produced by Compound 48/80, Histamine-liberator from Ascaris, Lecithinase A, and Antigen. Acta physiol. scand. 44, 157-162.

Holmgren, H. (1939). Über Vorkommen und Bedeutung der chromotropen (metachromatischen) Substanz in menschlichen Feten. Anat. Anz. 88, 246-251.

*Holmgren, H. (1940). Studien über die Verbreitung und Bedeutung der chromotropen Substanz. Zischr. mikt.-anat. Forsch. 47, 489-521.

*Holmgren, H. (1946). Beitrag zur Frage der Genese der Ehrlichschen Mastzellen. Acta. anat. $2,40-56$.

*Holmgren, H., \& Wilander, O. (1937). Beitrag zur Kenntnis der Chemie und Funktion der Ehrlichschen Mastzellen. Ztschr. mikr.-anat. Forsch. 42, 242-278.

Holmgren, H., \& Wohlfart, G. (1941). Om de basofila levkocyternas diagnostiska betydelse. Nord. med. 11, 2771-2774.

Holmgren, H., \& Wohlfart, G. (1947). Mast cells in experimental rat sarcomas. Cancer Res. 7 , 686-691.

Hopf, E. J. (1952). Über das Verhalten von Leukocyten und Mastzellen an Haut-Nabelschnurgrenze und Nabelschnur des Neugebornen. Frankfurt Z. Path. 63, 1-11.

Hule, V. (1950). Acute basophilic leukopenic ('aleukemic') leukaemia. Acta haenat. 3, 126.

IsıDoR, P. (1954). Étude sur la caractérisation histologique et histochimique de l’héparine. Bull. micr. appl. 4, 41-44.

JANES, J., \& MCDONALD, J. R. (1948). Mast cells. Their distribution in various human tissues. A.M.A. Arch. Path. 45, 622-634.

*Jaques, L. B., Bell, H. J., \& CHO, M. H. (1954). The physiology of heparin (pp. 281-297). Proc. I'r Iit. Conf. Thrombosis and Embolism (Basel).

JAQues, L. B., \& WATERS, E. T. (1941). The identity and origin of the anticoagulant of anaphylactic shock in the dog. .J. Physiol. (Lond.) 99, 454-466.

Josснім, G. (1906). Über Mastzellenleukämien. Dentsch. Arch. klin. Med. 87, 437-455.

JoHnstone, J. M. (1954). The appearance and significance of tissue mast cells in human bone marrow. J. clin. path. 7, 275-279.

Jolly, M. J. (1900). Clasmatocytes et mastzellen. C.R. Soc. Biol. (Paris) 52, 609-611.

JoRDAN, H. E. (1919). The histology of the blood and the red bone-marrow of the leopard frog, Rana pipiens. Amer. J. Anat. 25, 437-480.

Jordan, H. (1926). On the nature of the basophilic granulocytes of the blood and tissues. Anat. Rec. 33, 89-105.

Jordan, H. E., \& Flippin, J. C. (1913). Haematopoiesis in Chelonia. Folia haenat. (Lpz.) 15, 1-24.

Jordan, H. E., \& Speidel, C. C. (1923, 1924a, 1924b). Studies on lymphocytes.

I. Effect of splenectomy, experimental haemorrhage and a haemolytic toxin in the frog. Amer. J. Anat. 32, 155-167.

II. The origin, function and fate of the lymphocytes in fishes. J. Morph. 38, 529-546.

III. Granulocytopoiesis in the salamander, with special reference to the monophyletic theory of blood-cell origin. Anner. J. Anat. 33, 485-502.

Jordan, H. E., \& Speidel, C. C. (1930). Blood formation in cyclostomes. Amer. J. Anat. 46, $355-378$.

JoRPES, J. E. (1936). On heparin: its chemical nature and properties. Acta med. scand. 88, $427-433$.

JORPES, J. E. (1937). Über das Heparin und seine Anwendung als Ersatzmittel für Oxalat und Zitrat in der Klinik. Acta med. scand. Suppl. 89, 139-149.

*Jorpes, J. E. (1946). Heparin in the treatment of thrombosis, 2nd ed. London: Oxford University Press.

Jorpes, J. E., Holmgren, H., \& Wilander, O. (1937). Über das Vorkommen von Heparin in den Gefässwänden und in den Augen. Ztschr. mikr.-anat. Forsch. 42, 279-300.

Jorpes, J. E., Odeblad, E., \& BOSTRÖM, H. (1953). An autoradiographic study on the uptake of $\mathrm{S}^{35}$ labelled sodium sulphate in the mast cells. Acta haemat. (Lpz.) 9, 273-276.

Jorpes, J. E., Werner, B., \& Å BERG, B. (1948). The fuchsinsulphurous acid test after periodate oxidation of heparin and allied polysaccharides. J. biol. Chem. 176, 277-282. 


\section{BIBLIOGRAPHY}

Julen, C., Snellman, O., \& Sylvén, B. (1949). Cytological and fractionation studies on the cytoplasmic constituents of tissue mast cells. Acta physiol. scand. 196, 289-305.

KanthaCK, A. A., \& Hardy, W. B. (1894). The morphology and distribution of the wandering cells of mammalia.. J. Physiol. (Lond.) 17, 81-115.

KarDos, E. (1911). Über die Entstehung der Blutmastzellen aus dem Knochenmark. Folia haematol. (Lpz.) 11, 271-274.

Keller, R. (1957). Tissue mast cells in anaphylactic shock and anaphylactoid reactions. Int. Arch. Allergy 11, 328-34l.

Keller, R. (1958). Zur Bindung von Histamin und Serotononin in den Mastzellen. ArzmeimittelForsch. 8, 390-394.

Keller, R. von, \& Burkard, W. (1956). Die Bedeutung der Gewebemastzellen für die Histaminfreisetzung. Helv. Phisiol. Pharnacol. Acta 14, 289-298.

KindRED, J. E. (1926). A study of the genetic relationships of the 'Amebocytes with spherules' in Arbacia. Biol. Bull. 50, 147-153.

KirsCHNER, L. B. (1957). Phosphatidyl serine as a possible participant in active sodium transport in erythrocytes. Arch. biochem. 68, 499-500.

Kitanishi, T. (1956). Studies on the development of connective tissue fibres and mast cells in human embryos, with special reference to their histochemical relationship. Acta haemat. jap. 19, 53-63.

KNoll, W. (1932). Das morphologische Blutbild der Säugetiere. Allgemeine und spezielle Morphologie der kernhaltigen Blutzellen der Säugetiere. Z. nikr.-anat. Forsch. 30, 116-150.

KöKSAL, M. (1953). Extraction of a heparin-like substance from mast-cell granules in mouse connective tissus. Nature (Lond.) 172, 733-734.

Kolb, E. (1956). Untersuchungen über das Vorkommen von Histaminase und Diamioxydase im Serum von Haustieren (Wiederkäuer, Schweine, Pferde) sowie bei Escherichia coli und Streptococcus faecalis. Zbl. Veterinärmed. 3, 570-591.

Kollmann, M. (1908). Recherches sur les leucocytes et le tissu lymphoïde des invertébrés. Ann. Sci. nat. 8, 1-222.

Krabbe, K., discussion to Quensel, U. (1928). Acta path. microbiol. scand. 5, Supplement $34-38$.

LAguesSE, E. (1919). Sur le developpment des Mastzellen ou mastocytes chez le rat blanc. C.R. Soc. biol. (Paris) 82, $1415-1417$.

Lagunoff, D., Lam, K. B., Roeper, E., \& Benditt, E. P. (1957). 5-hydroxytryptamine formation from 5-hydroxytryptophan by mast cells. Fed. Proc. 16, 363.

LARSSON, L. G., \& SYlVÉn, B. (1947). The mast-cell reaction of mouse skin to some organic chemicals. 11. The effect of common organic solvents. Cancer Res. 7, 680-685.

LAZARENKO, T. (1925), Beiträge zur vergleichenden Histologie des Blutes und des Bindegewebes. II. Die morphologische Bedeutung der Blut- und Bindegewebeelemente der 1nsekten. Z. mikr.anat. Forsch. 3, 409-499.

*Lehner, J. (1924). Das Mastzellen-Problem und die Metachromasie-Frage. Ergebu. Anat. Entwickl. Gesch. 25, 67-184.

Leitner, S. J. (1949). Bone narrow biopsy. Haematology in the light of sternal puncture. Ed. Britton, C. J. C., \& Neumark, E. New York: Grune \& Stratton.

Lennert, K. von, Köster, E., \& Martin, H. (1956). Über die Mastzellenleukamie. Actahaenatol. $16,225-272$.

LEWIS, T. (1927). The blood vessels of the hmman skin and their responses. London: Shaw.

LeYDiG, F. (1857). Lehrbuch der Histologie des Menschen und der Thiere. Frankfurt-am-Mein: Meidinger.

LipschüTz, B. (1924). Untersuchungen über die Entstehung des experimentellen Teercarcinoms der Maus. Z. Krebsforsch. 21, 50-97.

Lison, L. (1935). Études sur la métachromasie. Colorants métachromatiques et substances chromotropes. Arch. de Biol. (Paris) 46, 599-668.

LoewenthaL, N. (1930). Nouvelles observations sur les globules blancs du sang chez les animaux vertébrés. Arch. Anat. (Strasbourg) 11, 245-332.

MacDougall, J. D. B. (1954). Experimental studies on neoplastic mast cells cultivated in ritro. Verl. Anat. Ges. (Jena) 52, 322-329.

MacDougall, J. D. B., \& Riley, J. F. (1954). Observations on neoplastic mast cells cultivated in vitro. Proc. Scot. Soc. Exp. Med., Glasgow meeting.

McGovern, V. J. (1956). Mast cells and their relationship to endothelial surfaces. J. Path. Bact.71, $1-6$.

McGovern, V. J. (1957). The mechanism of inflammation. J. Path. Bact. 73, 99-106.

Maclntosh, F. C. (1956). Discussion to Riley, Ciba Symposium on Histamine, p. 407. London: Churchill.

*Macintosh, F. C., \& Paton, W. D. M. (1949). The liberation of histamine by certain organic bases. J. Physiol. (Lond.) 109, 190-217.

McLean, J. (1916). The thromboplastic action of cephalin. Amer. J. Plysiol. 41, $250-257$.

Markowitz, A., Cifonelli, J. A., \& Dorfman, A. (1958). Biosynthesis of hyaluronic acid by cellfree extracts of group-A streptococci. Biochem. biophys. Acta. 28, 453-455. 
Marshall, J., Walker, J., Lurie, H. I., Hansen, J. D. L., \& Mackenzie, D. (1957). Solitary mastocytoma and the mastocytoses. A discussion of the mastocytoses and a report of two cases of solitary mastocytoma showing an unusual phenomenon of generalized flushing. S. Afr. med. J. 31, 867-876.

MARTIN, H. vON, \& ROKA, L. (1953). Zur Frage des Heparin-Gehaltes der Blutmastzellen des Menschen. Acta haemat. (Lpz.) 10, 26-31.

Marquardt, M. (1949). Paul Ehrlich. London: Heinemann.

Maximow, A. (1904). UUber entzündliche Bindegewebneubildung bei der weissen Ratte und die dabei auftretenden Veränderungen der Mastzellen und Fettzellen. Beitr. path. Anat. 35, 93-123.

Maximow, A. (1906). Über die Zellformen des lockeren Bindegewebes. Arch. mikr.-Anat. 67, $680-756$.

Maximow, A. (1910). Untersuchungen über Blut und Bindegewebe. 111. Die embryonale Histogenese des Knochenmarks der Säugetiere. Entstehung der Mastzellen. Arch. mikr.-Anat. 76, 63-69.

Maximow, A. (1913). Untersuchungen über Blut und Bindegewebe. VI. Über Blutmastzellen. Arch. mikr.-Anat. 83, 247-287.

Maximow, A. (1924). Relation of blood cells to connective tissues and endothelium. Physiol. Rev. 4, 533-563.

Maximow, A. (1926). Über undifferenzierte Blutzellen und mesenchymale Keimlager im erwachsenen Organismus. Klin. Wschr. 5, 2193-2199.

MeIrowSKY, E. (1908). Zur Frage des Ursprungs der Mastzellengranulationen. Folia haemat. (Lpz.) 6, 42-49.

MesserschmitT, J. (1954). Fréquence des Mastzellen dans les frottis de moelle osseuse chez l'homme. Rev. Hémat. 9, 189-197.

Meyer, K., discussion to ANGevine, D. M. (1950), pp. 13-43. Structure and function of normal connective tissue. 1st conf. on connective tissue. New York: Macey Foundation.

Michaelis, L. (1902). Über Mastzellen. Mïnch. Wschr. 49, 225-226.

Michels, N. A. (1922). Génèse héteroplastique et homoplastique des labrocytes (Mastzellen) chez les vertébrés inférieurs. C.R. Soc. Biol. (Paris) 87, 111-112.

Michels, N. A. (1923). The mast cell in the lower vertebrates. Cellule 33, 339-451.

*Michels, N. A. (1938). The mast cells. In H. Downey Handbook of Haematology', vol. I, pp. 232 354. New York: Hoeber. London: Hamilton.

Mollendorf, M. VON, (1928). Die Wirkung der künstlichen Höhensonnebestrahlung auf das subcutane Bindegewebe der weissen Maus. Z. Zellforsch. 6, 151-194.

Mongar, J. L., \& Schild, H. O. (1956). Effect of antigen and organic bases on intracellular histamine in guinea pig lung. J. Physiol. (Lond.) 131, 207-219.

Montagna, W. (1957). Histology and cytochemistry of human skin. XI. Distribution of $\beta-$ glucuronidase. J. biophys. biochem. Cytol. 3, 343-348.

Montagna, W., \& Noback, C. R. (1946). The histology of the preputial gland of the rat. Anat. Rec. 96, 4-54.

Montagna, W., \& Noback, C. R. (1948). Localization of lipids and other chemical substances in the mast cells of man and laboratory mammals. Anat. Rec. 100, 535-546.

Montagna, W., Eisen, A. Z., \& Goldman, A. S. (1954). The tinctorial behaviour of human mast cells. Quart. J. micr. Sci. 95, 1-4.

MoORE, J. E. \& JAMES, G. W. (1953). A simple direct method for absolute basophil leucocyte count. Proc. Soc. exp. Biol. (N.Y.) 82, 601-603.

Moore, R. D. (1956). Mast cells of the human umbilical cord. Amer. J. Path. 32, 1179-1182.

MoOre, R. D., \& SCHOENBERG, M. D. (1957a). Studies on connective tissue. I. The polysaccharides of the human umbilical cord. A.M.A. Arch. Path. 64, 39-45.

MoOre, R. D., \& SCHOENBERG, M. D. (1957b). Studies on connective tissue. II. Histochemical differences in the connective tissue polysaccharides of the mature and immature human umbilical cord. A.M.A. Arch. Path. 64, 167-170.

Morrione, T. G. (1952). The formation of collagen fibres by the action of heparin on soluble collagen. J. Exp. Med. 96, 107-112.

Mota, I., Beraldo, W. T., Ferri, A. G., \& Junqueria, L. C. U. (1954). Intracellular distribution of histamine. Nature (Lond.) 174, 698.

Mota, I., Beraldo, W. T., \& Junqueira, L. C. U. (1953). Protamine-like property of compound 48/80 and stilbamidine and their action on mast cells. Proc. Soc. Exper. Biol. (N.Y.) 83, 455-457.

Mota, I., Ferri, A. G., \& Junqueira, L. C. U. (1956). Action of peptone on the mast cells and histamine contents of dog tissues. Acta haemat. (Lpz.) 15, 409-416.

Mota, 1., Ferri, A. G., \& Yoneda, S. (1956). The distribution of mast cells in the digestive tract of laboratory animals: its bearings on the problem of the localization of histamine in tissues. Quart. J. micr. Sci. 97, 251-256.

mota, I., Junqueira, L. C. U., Beraldo, W. T., \& Ferri, A. G. (1954). Action of peptone on mast cells of the dog. Nature (Lond.) 173, 547-548. 


\section{B IBLIOGRA P HY}

Mota, I., \& Vugman, I. (1956). Effects of anaphylactic shock and compound 48/80 on the mast cells of the guinea pig lung. Nature (Lond.) 177, 427-429.

Mulligan, R. M. (1948). Statistical and histologic study of one hundred and twenty canine neoplasms. A.M.A. Arch. Path. 45, 216-228.

Murray, J. A. (1908). The Zoological distribution of cancer. 3rd Sci. Rept. Imp. Cancer Res. Fund, 41-60.

Nagayo, M. (1928). Studien über die Gewebsmastzellen. Zbl. allg. Path. path-Anat. 43, 289-293.

Nakajima, Y. (1928). Studien über Gewebsmastzellen. Trans. Jap. Path. Soc. 18, 150-156.

NetTLESHIP, E. (1869). Rare forms of urticaria. I. Chronic urticaria, leaving brown stains: nearly two years' duration. Brit. Med. J. 2, 323.

NeuberGer (1894), cited by Williams, 1900. Versamm. Deutsch. Naturforsch. u. Aertze.

Neugebauer, K., \& SChmid, J. (1949). Über die Histaminbindungsfähigkeit des Magenschleims. Wien. Z. inn. Med. 30, 383-388.

NeumanN, J. (1885). Über Plasmazellen. Rostock: Priesschrift. (Cited by Ballowitz, 1891.)

NeumanN, J. (1890). Über das Vorkommen der sogennanten 'Mastzellen' bei pathologischen Veränderungen des Gehirns. Virchows Arch. path. anat. 122, 378-386.

*Nickel, W. R. (1957). Urticaria pigmentosa. Mastocytosis: a consideration of various manifestations. A.M.A. Arch. dermatol. 76, 476-498.

Niflsen, S. W. (1952). Clinical aspects of mastocytoma in dogs: frequency, regional involvement, metastasis, recurrence, and differential clinical and pathological diagnosis, pp. 212-217. "Proceedings Book", Amer. Vet. Med. Assoc. 89th Anmual Meeting.

Nilzén, A. (1947). Studies in histamine (H-substance) with special reference to the conditions obtaining in urticaria and related skin changes. Acta. derm.-venercol. (Stockh.) 27, Suppl. 17.

Nishiyama, R., TASAKA, K., \& IRINO, S. (1957). The sites of action of some histamine-releasing substances in the dog. Acta Med. Okayama 11, 133-144.

Noback, C. R., \& Montagna, W. (1946). Some histochemical aspects of the mast cell with special reference to alkaline phosphatase and cytochrome oxidase. Anat. Rec. 96, 279-288.

Norton, S. (1954). Quantitative determination of mast-cell fragmentation by compound 48, 80 . Brit. J. Pharmacol. 9, 494-497.

NORTON, S., \& DE BEER, E. J. (1955). Action of histamine-liberators and antihistamines on mast cells in vitro. Fed. Proc. 14, 374.

NumERS, C. VON (1953). The rôle of vitamin C in the mucopolysaccharide metabolism of the skin. Studies on free mucopolysaccharides and mast cells in the intact skin and during wound healing in normal and scorbutic guinea pigs. Ann. Méd. exper. et biol. Fenniae 31, 398-408.

OHuYe, T. (1952). Supplementary observations on the basophilic granulocyte of the newt, Triturus pyrrhogaster, with special reference to those of some invertebrates. Mem. Ehime Univ. Sect. II 1, 193-199.

OHuYe, T., \& OCHI, O. (1954). Supplementary observations on the effects of splenectomy upon the newt, Triturus pyrrhogaster. Mem. Ehime Univ. Sect. IIB 2, 37-48.

OHuYe, T., \& Horikawa, M. (1956). Histology and chemical cytology of the hemocytes formed in a beetle, Xylotrupes dichotonus. Mem. Ehime Univ. (Biology) 2, 283-291.

Oliver, J., Bloom, F., \& Mangieri, C. (1947). On the origin of heparin. An examination of the heparin content and the specific cytoplasmic particles of neoplastic mast cells. J. Exp. Med. 86, $107-116$.

Oppel, A. (1889). Beitrage zur Anatomie des Proteus anguineus von Verdauungstractus. Arch. mikr.-Anat. 34, $511-572$.

OrR, J. W. (1938). The changes antecedent to tumour formation during the treatment of mouse skin with carcinogenic hydrocarbons. J. Path. Bact. 46, 495-515.

*Padawer, J. (1957). Studies on Mammalian mast cells. Tians. N.Y. Acad. Sci. 19, 690-713.

PADAWAR, J., \& GoRdon, A. S. (1955). Isolation of mast cells from other cellular elements of rat peritoneal fluid. Proc. Soc. Exp. Biol. (N.Y.) 88, 29-31.

Paff, G. H., Montagna, W., \& Bloom, F. (1947). Cytochemical studies of normal and tumour mast cells in tissue and in vitro. Cancer Res. 7, 798-801.

PafF, G. H., Bloom, F., \& Reilly, C. (1947). The morphology and behaviour of neoplastic mast cells cultivated in vitro. J. Exp. Med. 86, 117-123.

Paff, G. H., \& Mergenthaler, D. D. (1955). Vacuolation in normal mast cells treated with protamine sulphate. Anat. Rec. 121, 579-592.

Pappenheim, A. (1909). Einige interessante Tatsachen und theoretische Ergebnisse der vergleichenden Leukocytenmorphologie. Folia haemat. (Lpz.) 8, 504-563.

Pappenheim, A., \& ST. SzÉCSI (1912). Hämozytologische Beobachtung bei experimentellen Saponinvergiftung der Kaninchen (zugleich ein Beitrag zur Mastzellenfrage). Folia haemat. (Lpz.) 13, 25-42.

Paton, W. D. M. (1951). Compound 48/80: a potent histamine-liberator. Brit. J. Pharmacol. 6, 499-508.

Paton, W. D. M. (1955). Histamine metabolism. Int. Arch. Allergy 6, 203-229. 


\section{B I B LIOG RA PHY}

*Paton, W. D. M. (1957). Histamine release by compounds of simple chemical structure. Pharmacol. Rev. 9, 269-328.

*'Paton, W. D. M. (1958). The release of histamine. In, Progr. Allergy 5, 79-148. (S. Karger, Basel N. York.)

Paton, W. D. M., \& Schachter, M. (1951). The influence of an antihistaminic drug on the release of histamine in the unanaesthetized dog. Brit. J. Pharmacol. 6, 509-513.

Pautrier, L. M., \& Woringer, F. (1931). L'anatomie pathologique des chéloïdes. Ann. Derm. Syph. (Paris) 2, 1145-1179.

Pequegnat, W. E. (1948). Inhibition of fertilization in Arbacia by blood estracts. Biol. Bull. 95, 69-81.

Pfscetto, G. (1950). Sulla presenza di elementi granulosi basophili metacromatici nella placenta fetale umana. Biol. Lat. (Milano) 2, 744-757.

Petersen, W. F., \& Levinson, S. A. (1923). Studies in endothelial permeability. II. The rôle of the endothelium in canine anaphylactic shock. J. Immunol. 8, 349-359.

Peyron, A. (1923). Sur certains éléments lympho-conjonctifs du tissue sous-cutané de la souris et leur présence dans l'épithélioma expérimental du goudron. C.R. Soc. Biol. (Paris) 88, 151-154.

Piette, M. (1955). Sur la métachromasie des granulocytes (polynucléaires) basophiles du sang. C.R. Acad. Sci. Paris 240, 1366-1368.

Plesch, J. (1947). Janos, the story of a doctor. London: Gollancz.

Ponder, E., Yeager, J. F., \& Charipper, H. A. (1928a, 1928b, 1929).

Studies in comparative haematology: I. Camelidae. Quart J. exp. Physiol. 19, 115-126. Studies in comparative haematology: II. Primates. Quart. J. exp. Phisiol. 19, 181-195. Studies in comparative haematology: III. Marsupialia. Quart. J. exp. Physiol. 19, $273-283$.

Portier, P., \& Richet, C. (1902). De laction anaphylactique de certains venins. C.R. Soc. Biol. (Paris) 54, 170-172.

Pröscher, F. (1909). Über experimentalle basophile Leukocytose beim Kaninchen. Folia haemat. $(L p z) 7,.107-115$.

Prakken, J. R., \& Woerdeman, M. J. (1952). Mast cells in diseases of the skin; their relation to tissue eosinophilia. Dermatologica (Basel) 105, 116-123.

Quensel, U. (1928). Some investigations concerning mast cells. Acta path. microbiol. scand. Suppl. 5, 34-37.

*Quensel, U. (1933). Studien über die Gewebsmastzellen. Acta path. microbiol. scand. Suppl. 16, 358-375.

RAuDNitZ, R. W. (1883). Beitrag zur Kenntniss der im Bindegewebe vorkommenden Zellen. Arch. mikr.-anat. 22, 228-232.

Ranvier, M. (1890). Des clasmatocytes. C.R. Acad. Sci. (Paris) 110, 165-169.

Recklinghausen, F. von (1863). Über Eiter und Bindgewebskörperchen. Virchow's Arch. 28, 157-197.

Regaud, C., \& Lacassagne, A. (1922). A propos des mastocytes des épithélomas. Importance de la fixation pour la colouration des granulations des mastocytes. C.R. Soc. Biol. (Paris) 87, $1084-1086$.

*Remy, D. (1957). Systemic mast-cell disease. Germ. med. Monthly 2, 235-237.

RiLeY, J. F. (1948). Retardation of growth of a transplantable carcinoma in mice fed basic metachromatic dyes. Cancer Res. 8, 183-187.

Riley, J. F. (1953a). The relationship of the tissue mast cells to the blood vessels in the rat. J.Path. Bact. 65, 461-469.

RiLeY, J. F. $(1953 b)$. The effects of histamine-liberators on the mast cells of the rat. J.Path. Bact. 65, 471-479.

Riley, J. F. (1953c). Histamine in tissue mast cells. Science 118, 332-333.

RiLEY, J. F. (1954). The riddle of the mast cells. Lancet 1, 841-844.

* Riley, J. F. (1955). Pharmacology and functions of the mast cells. Pharmacol. Rev. 7, $267-277$.

RILEY, J. F. (1956). The location of histamine in the body in: Histamine, Ciba Foundation Symposium, in honour of Sir Henry Dale (pp. 398-402). London: Churchill.

Riley, J. F. (1958a). The mechanism of histamine release from mast cells. J. Pharm. Pharmacol. $10,271-272$.

Riley, J. F. (1958b). Fluorescent mast cells in precancerous mouse skin. Experientia 13, 141.

Riley, J. F. (1959). The mast-cell reaction in mouse skin treated with co-carcinogens. (To be published.)

Riley, J. F., \& DRENNAN, J. M. (1949). The presence and significance of alkaline phosphatase in the cytoplasm of mast cells. J. Path. Bact. 61, 245-251.

Riley, J. F., Shepherd, D. M., West, G. B., \& Stroud, S. W. (1955). Function of heparin. Nature (Lond.) 176, 1123.

Riley, J. F., \& WeST, G. B. (1953). The presence of histamine in tissue mast cells. J. Physiol. (Lond.) 120, 528-537.

Riley, J. F., \& WEST, G. B. (1955a). Tissue mast cells. Studies with a histamine-liberator of low toxicity (compound 48/80). J. Path. Bact. 69, 269-282. 


\section{B I B LIOGRAPHY}

Riley, J. F., \& West, G. B. (1955b). Histamine-liberation in the rat and mouse. Arch. int. pharmacodyn. 102, 304-312.

RILEY, J. F., \& WEST, G. B. (1956a). A binding site for histamine in hog pyloric mucosa. Experientia 12, 153.

RILEY, J. F., \& WEST, G. B. (1956b). Skin histamine: its location in the tissue mast cells. A.M.A. Arch. dermatol. 74, 471-478.

RINGOEN, A. (1919). Observations on the origin of the mast leucocytes of the adult rabbit. Preliminary note. Anat. Rec. 9, 233-242.

Ringoen, A. R. (1923). The mast leucocytes in the adult guinea pig under experimental conditions. Amer. J. Anat. 31, 319-335.

Rocha e Silva, M. (1952). Concerning the mechanism of anaphylaxis and allergy. Brit. Med.J. 1, 779-784.

Rocha E Silva, M. (1953). Activation by polysaccharides of a histamine-liberator (anaphylatoxin) in the blood plasma. Rev. canad. Biol. 12, 325-331.

*Rocha E Silva, M. (1955). Histamine, its rôle in anaphylaxis and allergy. Springfield, Illinois: Thomas.

Rocha E Silva, M., Scroggie, A. E., Fidlar, E., \& Jaques, L. B. (1947). Liberation of histamine and heparin by peptone from the isolated dog's liver. Proc. Soc. Exper. Biol. (N.Y.) 64, 141-146.

Rogers, G. E. (1956). Electron microscopy of mast cells in the skin of young mice. Exp. Cell Res. 11, 393-402.

Romieu, M. (1924). Contribution a l'étude des mastocytes des poissons osseux. C.R. Soc. biol. 91, $655-657$.

RosenHeIM, T. (1886). Über das Vorkommen und die Bedeutung der Mastzellen im Nervensystem des Menschen. Arch. Psicl. Nervenkrank 17, $820-829$.

SABrazł̀s, J. (1926). Présence d'hémohistioblastes se différenciant en Mastzellen dans un cas de myéloleucémie chronique (radio-résistance des hémohistioblastes). Arcll. Mal. Coeur 19, 38-42.

Sabraż̀s, J., \& Husnot, P. (1907). Tissu interstitiel des surrénales: Mastzellen et Macrophages. C.R. Soc. Biol. (Paris) 62, 1079-1084.

SABrazès, J., \& LAFON, C. (1907). Granulome de la lèvre à Mastzellen et à éosinophiles chez un cheval. C.R. Soc. Biol. (Paris) 63, 715.

Sabraż̇s, J., Muratet, L., \& Antoine, H. (1908). Infiltration massive de mastzellen agglomérées en nodules dans la rate d'un chat porteur d'un epithélioma de la paupière. C.R. Soc. Biol. (Paris) 64, 292-293.

SAGHER, F. (1956). Milestones in dermatology. XX. Mast-cell disorders: the changing aspects of urticaria pigmentosa from a pure cutaneous to a systemic disease. Excerpta med. (Amst.) Sect. XIII 10, 311-313.

Samter, M., Kofoed, M. A., \& PiePer, W. (1953). A factor in lungs of anaphylactically shocked guinea pigs which can induce eosinophilia in normal animals. Blood 8, 1078-1089.

Sansonow, N. M. (1909). Wanderelemente der Darmschleimhaut bei Säugertieren. Folia haematol. (Lpz.) 8, 227-228.

SchafFER, J. (1907). Über das Farben der 'grobkörnigen, oder sogennanten Mastzellen' des Bindegewebes. Zbl. Physiol. 21, 258-262.

SCHAYER, R. W. (1956). Formation and binding of histamine by free mast cells of rat peritoneal fluid. Amer. J. Physiol. 186, 199-202.

SCHAYER, R. W., \& KoBayashi, Y. (1956). Histidine decarboxylase and histamine binding in rabbit platelets. Proc. Soc. exp. Biol. (N.Y.) 92, 653-655.

Schild, H. O. (1949). Release of histamine by ammonia. Nature (Lond.) 164, 24-25.

SCHILD, H. O., \& GREgory, R. A. (9417). Liberation of histamine from striated muscle by curarine, strychnine and related substances. Proc. XVII Internat. Physiol. Congr., Oxford, p. 208.

SchmidT-Mülheim, A. (1880). Beiträge zur Kentniss des Peptons und seiner physiologischen Bedeutung. Arch. Anat. Physiol. (Lpz.), 33-56.

Schoenberg, M. D., \& Moore, R. D. (1958). Studies on connective tissue. III. Enzymatic studies on the formation and nature of the carbohydrate intermediate of the connective tissue polysaccharides in the human umbilical cord. A.M.A. Arch. Path. 65, 115-124.

Schreuss, H. T. (1923). Über einen Mastzellen-Tumor bei den weissen Maus nach Teerinselung. Derm. Z. 40, 9.

Schwenter-Trachsler, J. (1906). Neuere Befunde an Mastzellen der Haut. Folia haemat. (Lpz.) 3, 519-527.

Sjoerdsma, A., WaAlkes, T. P., \& Weissbach, H. (1957). Serotonin and histamine in mast cells. Science 125, 1202-1203.

Smith, D. E. (1958). Nature of the secretory activity of the mast cell. Amer. J. Physiol. 193, $573-575$.

SMITH, D. E., \& LEwIS, Y.S. (1955). Electronmicroscopy of mast cells after X-irradiation and treatment with chemical agents. Amer. J. Physiol. 183, 662-663.

Snellman, O., Jensen, R., \& Sylvén, B. (1948). A new extraction procedure for the preparation of heparin. Nature (Lond.) 161, 639. 


\section{B I B LIOGRAPHY}

Snellman, O., Sylvén, B., \& Julen, C. (1951). Analysis of the native heparin-lipoprotein complex including the identification of a heparin complement (heparin co-factor) obtained from extracts of tissue mast cells. Biochim. biophys. acta 7, 98-109.

Squartini, F., Caschera, F., Passaretti, J. R., \& Rossı, G. (1956). Significato istafunzionale delle mastzellen. I1. Le mastzellen nell' ulcera gastrica. Lav. 1st anat. Univ. Perugia 16, 369-373.

Squartini, F., \& Giacanelli, F. (1956). Le mastzellen nel sistema nervoso centrale. Lav. 1st anat. Univ. Perugia 16, 383-387.

Stockinger, W. (1927). Das lockere Bindegewebe der weissen Maus in verschiedenen Lebensaltersstufen, mit besonderer Berücksichtigung der Mastzellen und der Gebewbsleukozyten. Z.Zellforsch. mikr.-anat. 6, 27-60.

Stoeckenius, W. (1956). Zur Feinstruktur der Granula menschlicher Gewebsmastzellen. Exp. Cell Res. 11, 656-658.

St. SzÉcsi (1913). Lucidol, ein neues Fixiermittel. Deutsch. med. Wschr. 39, 1584-1585.

*Staemmler, M. (1921). Untersuchung über Vorkommen und Bedeutung der histiogenen Mastzellen im menschlichen Korper unter normalen und pathologischen Verhaltnissen. Frankfurt Z. Path. 25, 391-435.

Stuart, E. G. (1952). Mast-cell responses to anaphylaxis. Anat. Rec. 112, 394.

SUNDBERG, M. (1955). On the mast cells in the human vascular wall; a quantitative study on changes at different ages. Acta path. microbiol. scand. Suppl. 107.

Sundberg, R. D., Schaar, F. E., Powell, M. J., \& Denboer, D. (1954). Tissue mast cells in human umbilical cord, and the anticoagulant activity of dried extracts of cords and placentae. Anat. Rec. 118, 35-52.

SYlvén, B. (1940). Studies on the liberation of sulphuric acids from the granules of the mast cells in the subcutaneous connective tissue after exposure to Roentgen and gamma rays. Acta Radiol. (Stockh.) 21, 206-212.

*SYlvéN, B. (1941). Über das Vorkommen von hochmolekularen Esterschwefelsauren im Granulationsgewebe und bei der Epithelregeneration. Acta. chir. scand. 87, Suppl. 66.

SYlvéN, B. (1945). Ester sulphuric acids of high molecular weight and mast cells in mesenchymal tumours. Acta radiol. (Stockh.) Suppl. 59.

SYLvÉn, B. (1957). On the topographical cytochemistry of tissue mast cells. In Ed., R. E. TunBRIDGE, pp. 27-34. Connective Tissue, a symposium organized by the Council for International Organizations of Medical Sciences. London: Blackwell.

TAYlor, H. E., \& SAUnders, A. M. (1956). The association of granulation tissue ground substance with fibroblastic activity. Amer. J. Path. 32, 617.

THIN, G. (1877). On the microscopic appearances of the skin of a patient whose case is described by Mr. Morrant Baker in the 8th volume of this Society's transactions. Trans. clin. Soc. (Lond.) 10, 198-203.

TODORO, F., cited by BURKL (1952).

*Trincão, R. A. C. (1953). Os mastócitos alguns aspectos da sua fisiopatologia. Arqu. Inst. Pat. Coimbra, Vols. VII \& VIII.

Tsusaki, 'T., Eriguchi, K., \& Kojo, Y. (1951). Basophilic cells in choroid plexus of lateral ventricle. Yokohama med. Bull. 2, 110-117.

Tulasne, R., \& Vendrely, R. (1947). Demonstration of bacterial nuclei with ribonuclease. Nature (Lond.) 160, 225-226.

Twort, C. C., \& TwOrT, J. M. (1930). Classification of four thousand experimental oil and tar skin tumours of mice. Lancet 1, 1331-1335.

Ulesco-Stroganowa, K. (1927). Über die Bedeutung des Bindegewebes bei der Krebsentwicklung. Z. Krebsforsch. 25, 394-406.

UNDRITZ, E. (1946). Die nicht zur Blutkörperchenbildung gehorenden Zellen intravitaler knochensmarkpunktate nebst Auszählungschema für Myelogramme. Schweiz. med. Wschr. 76, 333-337.

UnNA, P. G. (1894). Über mucinartige Bestandteile des Neurofibrome und des Zentralnervensystems. Monats. Prak. Derm. 18, 57-67.

UnNA, P. G. (1896). The histopathology of the diseases of the skin. Edinburgh: Clay; New York: Macmillan.

Urist, M. R., \& MCLEAN, F. C. (1957). Accumulation of mast cells in endosteum of bones of calciumdeficient rats. A.M.A. Arch. Path. 63, 239-251.

Urtubey, L. (1948). Nouvelles observations sur la signification des mastocytes (mixoblastes). I. Notes sur la manifestation embryonnaire et sur la distribution organique. Bull. Histol. Tech. micr. 25, 151-155.

Uvnäs, B. (1958a). The mechanism of histamine-liberation. J. Pharm. (Lond.) 10, 1-13.

UvNÄs, B. (1958b). Histamine release from mast cells by lecithinases A and C. J. Pharm. (Lond.) 10,336 .

VAughn, J. (1953). The function of the eosinophile leukocyte. Blood 8, 1-13.

Vercauteren, R. (1953). The properties of the isolated granules from blood eosinophils. Enzymologia 16, 1-13. 
Waalkes, T. P., Weissbach, H., Bozicevich, J., \& Udenfriend, S. (1957). Ser otonin and histamine release during anaphylaxis in the rabbit. J. clin. invest. 36, 1115-1120.

Waldeyer, W. (1875). Über Bindegewebszellen. Atch. mikr.-Anat. 11, 176-194.

WEBB, R. L. (1931). Peritoneal reactions in the white rat with especial reference to the mast cells. Amer. J. Anat. 49, 283-331.

WebB, R. L. (1935-6). Numerical changes of mast cells within the dermis of the white rat. Anat. Rec. 64, Supplement 122, 55.

Wegelius, O., \& Huelmman, G. (1955). Vital staining of mast cells and fibrocytes. Acta path. microbiol. scand. 36, 304-308.

Wegelius, O., Huelmman, G., \& Wasastjerna, C. (1955). Morphological changes caused by antihamster serum in the mast cells of the hamster. Acta path. microbiol. scand. 36, 309-315.

Weidenreich, F. (1908). Zur Kenntnis der Zellen mit basophilen Granulationen im Blut und Bindegewebe. Folia haemat. (Lpz.) 5, 135-155.

Weill, P. (1919). Mastzellenstudien an Sarkommetastasen. Folia haemat. (Lpz.) 23, 185 -196.

Werle, E. (1955). Über eine Bindung des Histamins an Heparin. Naturiss 21, 583.

Werle, E., \& Amann, R. (1956). Zur Physiologie der Mastzellen als Träger des Heparins und Histamins. Klin. Wscht. 34, 624-630.

Wermel, E., \& Sassuchin, D. (1927). Untersuchungen über die Kernsubstanzen und die Methoden ihrer Darstellung. II. Über die Natur des Volutins und der Mastzellen-Granula. Z. Zellforsch. 6,424439 .

West, G. B. (1955). Histamine in mast-cell granules. J. Pharm. pharmacol. 7, 80.

WEST, G. B. (1956). Histamine and mast cells. In Ciba Simposium, pp. 14-19, London: Churchill.

*West, G. B., \& Parratt, J. R. (1957). 5-hydroxytryptamine and the skin. Arch. dermatol. 76, 336-342.

West, G. B., \& Riley, J. F. (1954). Chromatography of Tissue Histamine. Nature (Lond.) $174,882$.

WestPhal, E. (1891). Über Mastzellen. In: Ehrlich, P. Farbenanalytische Untersuchungen, pp. 17-41. Berlin: Hirschwald.

White, R. P., \& WoOdard, P. H. (1957). Heparin content of thoracic duct lymph following shock in dogs. Amer. J. Phisiol. 188, 189-192.

WichmanN, B. E. (1955). The mast-cell count during the process of wound healing. An experimental investigation on rats. Acta path. microbiol. scand. Suppl. 108.

WiggleswORTH, V. B. (1956). The haemocytes and connective tissue formation in an insect, Rhodnius prolixus (Hemiptera). Quart. J. micr. Sci. 97, 89-98.

*Wilander, O. (1938). Studien über Heparin. Skand. Arch. Physiol. 81, Suppl. 15.

Williams, G. T. (1952). Tissue mast cells in human bone marrow. Amer. J. clin. Path. 22, 10391043.

Williams, H. U. (1900). A critical summary of recent literature on plasma-cells and mast cells. Amer. J. Med. Sci. 119, 702-709.

Wislocki, G. B., Bunting, H., \& Dempsey, E. W. (1947). Metachromasia in mammalian tissues and its relationship to mucopolysaccharides. Amer. J. Anat. 81, 1-31.

WISLOCKI, G. B., \& FAWCETT, D. W. (1951). Some histochemical properties of mast cells and tissue eosinophils in stained spreads of normal rat mesentery. J. nat. cancer Inst. 12, 258.

Woglom, W. (1926). Experimental Tar Cancer. General review. Aich. Path. 2, 533-576 \& 709 752.

ZimmermanN, A. (1908). Über das Vorkommen der Mastzellen beim Meerschweinchen. Arch. mik\%-Anat. scand. 62, 662-669.

Zollinger, H. U. (1950). Gewebsmastzellen und Heparin. (Phasenmikroskopische Untersuchung.) Experientia, 6, 384-386. 



\section{INDEX}

\section{A}

Adrenals, mast cells in, 22

Alimentary tract, lower vertebrates, mast cells in, 9

Amino acids, basic, in mast cell, 125, 126, 162

Amoebocyte with spherules, 6

Amphibia, blood formation in, 7 mast cells in, 7

Amphioxus, 7

Anaemia, aplastic, mast cells in, 20

Anaphylatoxin, $65,67,68-70$

Anaphylaxis, 20, 34, 35, 36, 37, 65, 69, 137, 160 in $\operatorname{dog}, 137,139$

in guinea pig, 69, 139

in hamster, 69

in mouse, 69

in rabbit, 139

in rat, $65,69,137$

mast cells in, 20

Angiomas, mast cells in, 24

Anti-histamines, 66, 70, 127

Anurans, mast cells in, 7, 9

Appendix, mast cells in, 21

\section{B}

Basophil (blood mast cell, mast leucocyte), 4, 17 20,92

Bat, mast cells in, 13

Batrachians, mast cells in, 9

Benzpyrene-caffeine, 127

Birds, blood formation in, 8

Birds, liver, mast cells in, 10

Blood formation, in birds, 8 in fishes, 7 in amphibia, 7

Blood mast cell, see basophil

Blood-vascular system, comparative development of, 7-9

Blood vessels, lower vertebrates, mast cells around, 9-10

higher vertebrates, mast cells around, 8,13 , $14,15-16,24,29,33,37,39-45,48-58$, $95-97,108,137,160,161$

Bone marrow, tissue mast cells in, 19-20

Bone, rabbit, mast cells in, 19

rat, mast cells in, 20,154

Brain, mast cells in, 13,14, 16

Breast, mast cells in, 21

Bullfrog, granular cells in, 11

\section{C}

Calf, mast cells in, 13

Capsules, mast cells in, 13, 39, 72-74, 85, 162

$\beta$-carboline compound, 159

Carcinogenesis, mast cells in, 26-27, 152-159, 164

Carcinoma, mast cells in, 21, 23

Cartilage, 146

Cat, basophils in, 18

mast cells in, $13,74-75,149-152,163$
Central nervous system, mast cells in, 13, 14, 16

Chromatography, 124, 128, 159

Clasmatocyte, and mast cell, 5

Clotting time, 138-139

Coarse granulocyte, in lower vertebrates, 6, 9

Coelenterates, granular cells in, 6

Compound 48/80, 93-108, 109-119, 127, 138, 162

intra-arterial injection, 94, 105, 107

mode of action, 106-108, 113-115, 127, 162

Connective tissue, $36,58,97,102,122,139-143$, 160,163

mast cells in, 14, 15, 20,21, 22, 24, 25, 27, $96-97,99,101,102,104,108,122,139-143$

Cortisone, 154

Crayfish, granular cells in, 7

Cyclostomes, blood formation in, 7

\section{D}

1, 2, 5, 6-dibenzanthracene, 33

Dog, mast cells in, 13-14

liver, mast cells in, $13,28,34-35,59,74,85-86$, 137-138

\section{E}

Ear, histamine, in cattle, 144

in mouse, 146

in pig, 145-146

in ox, $145-146$

in rat, $18,98,107$

Echinoderms, granular cells in, 6

Elasmobranchs, mast cells in, 10

Elastic tissue, 153

Electrophoresis, 116

Elephantiasis, mast cells in, 22

Embryo, man, mast cells in, 14-15, 140 rat, mast cells in, 14,140

Embryonal (" plasma") cell, 4

Endothelium, 143

Eosinophil, 11, 161 relation to mast cell, 11

Ester sulphate, 74

Evan's blue, 40

Fat cells, relationship to mast cells, 13, 102

Fibroblast, 102, 139-143

Fibroids, uterine, mast cells in, 24

Fibromas, mast cells in, 24

Fibrosarcomas, mast cells in, 24

Fishes, basophils in, 17

bony, blood formation in, 8

cartilagenous, blood formation in, 7

gut, granular cells in, 12

mast cells in, 7, 9

Fluorescence, 60, 62, 66, 68, 127, 153-9, 162, 164

Formaldehyde, 159

Free chromotrope substance, and mast cells (see also metachromasia), 23, 24, 33, 141-142 
G

Ganoid fishes, mast cells in, 9, 10

Gingivitis, mast cells in, 21

Goat, mast cells in, 13

Gonads, lower vertebrates, mast cells in, 10

Granulosa cell tumour, mast cells in, 25

Ground substance, 102, 140-143

Guinea pig, basophils in, 18, 19 mast cells in, 13 histamine-liberation in, 109, 115

\section{$\mathrm{H}$}

Hagfish, blood formation in, 7

Hare, mast cells in, 13

Heart, lower vertebrate, mast cells in, 9-10

Hedgehog, 13

Heparin complement, 40

Heparin, 28-29, 33, 34, 36, 69, 71, 85, 124-125, $130,137-143,153,160,163$

assay, 85

discovery, 28

extraction, 85

in anaphylaxis, 35-36, 139

in blood, 29, 161

in connective tissue, 139-143

in mast-cell granule, 124-125, 130

in mast-cell tumours, 29, 85-91

cat, 87-89, 91

cattle, 89-90

dog, 79-87, 91

mouse, 90-91

in kidney, 85

in liver, 28, 34-36, 59, 85

in lung, 85

in lymph node, 85

in pathological conditions, 77-92

in peptone shock, 34, 137-138

in skin, 85

in subcutaneous tissue, rat, 138-139

in spleen, 85

relationship to hyaluronic acid, 142

staining, 28,124

sulphate, $28,74,124$

toluidine blue, precipitation by, 28

Histamine, assay, 71, 145

binding, in mast cells, 116-129

content, per mast cell, 73-74

effects of, on mast cell, 64

non-mast cell, 132-136

profiles, skin, 144-152

stomach, 134-136

in anaphylaxis, $35-36$

in blood, 92,161

in capsules, $72,74,122$

in ear, cattle, 144-145

mouse, 146

pig, 144-145

rat, 146

in gastro-intestinal tract, rat, 132-136

in inflammation, 108

in liver, $34,59,72,74,125,132$

in lung, $75,85,86$

in lymph, 137

in mast-cell granule, 116-129

in mast-cell tumours, 83-90, 125
Histamine-continued

in normal tissues, 71-76

in pathological conditions, 77-92

in peptone shock, 34, 137-138

in skin, normal, $75,144-152$

precancerous, 152-159

in stomach, 134-136, 163

in rat, $72,93-108,109-115,119,122,124,146-$ 150,154

in urticaria pigmentosa $36-37,77-79$

Histamine-liberators, 37, 59-70, 93-108, 109-115, $137-139,162-163$

alkali, 117-119

compound 48/80, 93-108, 109-115, 127, 138, 162

decamethylene diamine, 59, 139

endogenous, 128

enzymatic, 130

heptamethylene diamine, 59

2-hydroxy stilbamidine, 59, 60, 68

5-hydroxytryptamine, 124

pentamidine, 59, 63

peptone, 59,63

propamidine, 59,63

stilbamidine, $59,60,66,68,93,162$

toluidine blue, 130

D-tubocurarine chloride, 59

tryptamine, 124

water, $67,119-125,128$

Histamine-profile, skin, cat, 150-152

stomach, pig, 134-136

rat, $133-134$

Histaminase, 90

Histidine, 132

5-hydroxytryptamine in mast cell, 124, 125, 154, 164

in mast-cell tumours, dog, 154

in mast-cell tumours, mouse, 91, 154

in mast-cell tumours, cattle, 154

5-hydroxytryptophan, 125

Hyaluronic acid, 142

\section{I}

Ichthyopsida, mast cells in, 7, 9, 10

Inflammation, acute, mast cells in, 22, 108, 128 chronic, mast cells in, 21

Insects, granular cells in, 7

Intestine, mast cells in, 13, 15

lymphoid tissue, mast cells in, 20

Interendothelial cement, 137

Invertebrates, mast cells in, 6-7

Itching, 110, 111, 112

Joints, mast cells in, 21

\section{K}

Keloid, mast cells in, 22, 33

Kidney, lower vertebrates, mast cells in, 10 cattle, mast cells in, 43

man, mast cells in, 21

$\mathrm{L}$

Lamprey, blood formation in, 7

Lathyrus syndrome, mast cells in, 20 


\section{NDEX}

Lecithin, 127, 128, 130, 162

Leukaemia, basophilic, 19, 91 myeloid, basophils in, 17, 18, 19 tissue mast-cell, 19

Liver, birds, mast cells in, 10 dog, heparin in, 28 mast cells in, $13,28,34-35,59,74,85-86$, 137-138

ichthyopsida, mast cells in, 10

lower vertebrates, mast cells in, 10 ox, heparin in, 28,85

ox, mast cells in, $13,72-74,85$

rabbit, mast cells in, 13

rat, mast cells in, 13,14

salamander, mast cells in, 10

urodele, mast cells in, 10

Lower vertebrates, mast cells in, 9-10

Lung fish (African), blood formation in, 7

Lung, mast cells in, 22, 39-40, 48, 75, 85, 87

Luteoma, mast cells in, 25

Lymph nodes, 36

mast cells in, 16, 45, 85, 87, 88

Lymphatics, 8, 137, 143

Lymphoid tissue, mast cells in, 20, 45

\section{M}

Macrophage, 96, 100, 123, 124, 139

Man, basophils in, 18, 19

survey of mast cells in, 14-16, 150, 152

Mast cell and alkaline phosphatase, 33

and fibrillogenesis, 58, 139-143, 161

and free chromotrope substance, 23, 24, 33, 141-142

degenerate, 5

degranulation, $63,64,96,99,107,111$

derivation, name, 3,17

discovery, 3,21

disruption, 63, 64, 96, 130-131

effects on, of ammonia, 118

of anti-histamines, 66, 70

of bases, 126

of heat, 64

of histamine-liberators, 37, 59-70, 93-108, $119-125,128,130$

of oedema, $64,68,137-139,162-163$

of $p \mathrm{H}, 116-119$

of sodium hydroxide, 117, 118

of trichloracetic acid, 125-126

of water, 57, 119-125, 128

granule, aminoacids in, 125-126, 162

enzymes in, 124-125

heparin in, 124-125, 130

histamine in, 124-125

5-hydroxytryptamine in, 124

phospholipids in, 126-128

solubility, $5,67,122-124$

sulphate in, 124

heparin in, $28-29,33,34,72,124-125,137-$ $139,162,163$

histamine in, 34-37, 71-76, 77-92, 139-143, $150-153,160,161,163$

histochemistry of, 124-125

5-hydroxytryptamine in, 124, 154-159

in adrenal, 43

in anurans, 7,9

in anaphylaxis, 65,69
Mast cell, etc.-continued

in batrachians, 9

in blood (see basophils)

in bone marrow, 19-20, 154, 157-158

in capsules, $13,28,39,58,72-74,85,162$

in carcinogenesis, 26-27, 152-159, 164

in cat, $13,74-75,149-152,163$

in cattle, 13, 14, $39-48,72,74,75,85,161$

in central nervous system, 13,14, 16

in choroid plexus, 16, 45

in connective tissue, $15,20,21,22,24,25,27$, $34,43,45,48,52,58,138,139-143,153$, $160,161,163$

in cow, 74,75

in dog, $13,28,34,59,74,75,137$

in ear, 93, 94, 144-147, 152

in embryo, 14-15, 76, 144

in fishes, 9, 10, 19

in Ichthyopsida, 9

in inflammation, acute, 2

chronic 21-22, 153

in intestine, $8,12,14,15,58,134-136$

in invertebrates, 6-7

in joints, 40,58

in kidney, 43,85

in lathyrus syndrome, 20

in liver, $10,13,14,28,34,36,39-40,58,59$, $72-74,85,88,89,137,138,162$

in lung, $22,39-40,48,75,85,87$

in lymph nodes, $16,45,85,87,88$

in mammary glands, 49

in man, $14-16,25,75,150,152$

in mesentery, 52, 94, 95

in milk spots, 62,95

in muscles, 48,58

in nerves, $16,45,100$

in oedema, 68,108

in oesophagus, 48

in omentum, 8, 53-54, 94, 95

in osteitis fibrosa, 20

in ox, 13, 14, 39-48, 72, 74, 75, 85, 161

in paronychia, 21

in pathological conditions, 21-27, 77-92

in peptic ulcer, 22

in peptone shock, 34,137

in pericardium, 40,58

in peritoneum, $40,54,60,122,138$

in pig, 13, 134-136

in pleura, $58,70,162$

in precancerous skin, 152-159, 164

in rat, $14,48-58,59-70,161$

in serous membranes, $8,14,39,161$

in sheep, 74,75

in skin, $15,22,26-27,58,85,87,145-152$, 163-164

in spleen, $85,87,88,89$

in stomach, 48, 132-136

in subcutaneous tissue, 94

in tendon sheaths, 40

in thymus, $13,16,43,48$

in thyroid, 43

in tissue culture, $26,83,90$

in tissue imprints, 82

in tissue spreads, $39-48,49-58,60-70,72-$ 74,122

in tongue, 15,48 


\section{INDEX}

Mast cell, etc.-contimued

in tumours, 21, 22-27, 79-91

in urodeles, $5,9,10$

in urticaria pigmentosa, $25,36,77-78,91$

membrane, 130

nucleus, 124

relationship to, blood vessels, 13, 15-16, 24, $29,33,37,39-45,48-58,95-97,108,137$, 160,161

clasmatocyte, 5

eosinophil, 11-12, 161

fat cells, 13, 102

lymphatics, 39-40, 45

reciprocal, in blood and tissues, 8,19

sulphate in, 124

staining, 39, 82-83, 88, 95, 122

tumours, $79-91,154$

in cat, 26, 79, 87-89, 160, 162

in cattle, 26, 79, 89-90, 128

in dog. 26, 29, 79-87

in horse, 26,79

in man, 25

in mouse, 26, 90-91, 128, 154-155

rapid diagnosis of, 82

water, effects of, 67, 119-125, 153

Mast leucocyte, see basophil

Mast myelocyte, 5

Mesentery, rat, mast cells in, 52-54, 67, 95-108

Metachromasia, $3,11,15,23,28,33,37,50,58$, $68,102,122,124,134,136,138,142,153$

Milk spots, mast cells in, 20,95, 97

Mitochondria, 125

Mouse, basophils in, 19

Mucin, 136

Mucopolysaccharide, 142, 163

Myelin, 162

Myelin figures, 126-127

Myocardium, mast cells in, 22

\section{$\mathrm{N}$}

Nerves, peripheral, mast cells in, 16, 22

Neurofibromas, mast cells in, 24

\section{$\mathrm{O}$}

Oedema, 108, 110, 111, 141-142, 163

Omentum, rat, mast cells in, 20,95, 98, 103

Osteitis fibrosa, mast cells in, 20

\section{$\mathrm{P}$}

Pathological conditions, mast cells in, 21-27

Peptone shock, 34, 35, 37, 137-138, 160, 163

Peritoneum, mast cells in, 13

Phosphatides, in mast cells, 127-128, 130, 162

Profile, mast cell-histamine, skin, cat, 150-152 stomach, rat, 133-134 stomach, pig, 134-136

Prostate, mast cells in, 21

\section{$\mathrm{R}$}

Rabbit, basophils in, 17, 18, 19 mast cells in, 13
Rat, basophils in, 18, 19

mast cells in, $13,14,48-58,59-70,72,93-108$, $109-115,116-131,134,138,139,146-152$, $161,162,163$

Regional ileitis, mast cells in, 21

Reptiles, basophils in, 17 mast cells in, 9

Reticuloses, mast cells in, 20, 25

$$
\mathrm{S}
$$

Salamander, terrestrial, liver, mast cells in, 10

Serous membranes, mast cells in, 39, 161

Skin, 15, 22, 26-27, 75, 78, 85, 144-159, 163 mast cells and histamine in cat, 144, 147-150, $151-152,163$

in $\operatorname{dog}, 144,152$

in guinea pig, 144, 150

in man, $79,144,147,150$

in mouse, 144, 147-150

in ox, 144-146

in pig, 144-146

in rabbit, 144,150

in rat, $144-150$

precancerous, mouse, 152-159

Splenic tumour, mast cells in, 24

Sponges, granular cells in, 24

Syphilis, mast cells in, 21

\section{$\mathrm{T}$}

Thoracic duct, 36, 137-138

Thymus, mast cells in, 13,16

Tissue culture, mast cells in, 26, 83, 90

Tongue, mast cells in, 15

Trichloracetic acid, effect of mast cells, 125-126, 162

Tuberculosis, mast cells in, 21

Tumours, mast cells in, 21, 22-27

\section{$\mathrm{U}$}

Umbilical cord, 141

mast cells in, 15

metachromasia in, 15

Urodele, liver, mast cells in, 10

Urticaria pigmentosa, $25,36,77-79,91,160,162$

Uterus, mast cells in, 21

\section{V}

Vertebrates, mast cells in, 9-16

higher, mast cells in, 13-16

lower, mast cells in, 9-12

basophils in, 17-19

Volutin, 6

\section{W}

Wharton's jelly, metachromasia and mast cells in, 15

Wound healing, mast cells in, 22

$\mathrm{Z}$

'Zellgewebe', in crayfish, 7 





